$$
\begin{aligned}
& \text { UNIVERSIDADE DE SÃ̃O PAULO } \\
& \text { INSTITUTO DE GEOCIENNCIAS }
\end{aligned}
$$

\title{
AS FORMAÇÕES SUPERFICIAIS DO NOROESTE DO PARANÁ E SUA RELAÇÃO COM O ARENITO CAIUÁ
}

\author{
NELSON VICENTE LOVATTO GASPARETTO
}

Orientador: Prof. Dr. Adilson Carvalho

\section{TESE DE DOUTORAMENTO}

COMISSÃO JULGADORA

\section{Nome}

Presidente:

Prof. Dr. Adilson Carvalho

Examinadores: Prof. Dr. Adolpho José Melfi

Prof ${ }^{\text {a. }} r^{\text {a. }}$ Maria Tereza de Nóbrega

Prof. Dr. Mario Sérgio de Melo

Prof ${ }^{\mathrm{a}} \cdot \mathrm{Dr}^{\mathrm{a}} \cdot$ Selma Simões de Castro
Assinatura

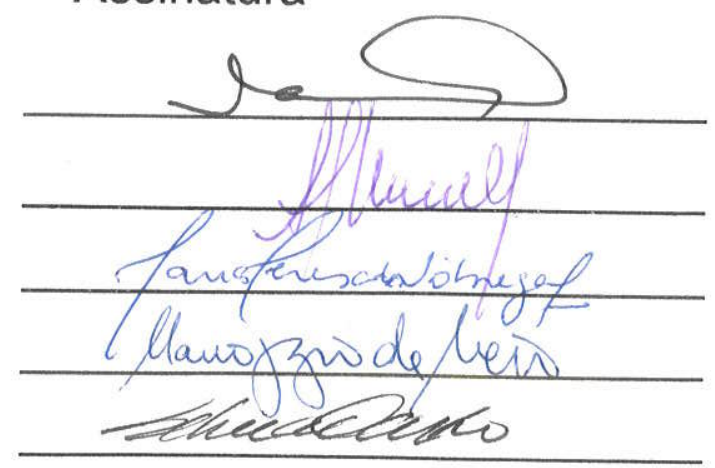

SÃO PAULO

1999 


\section{UNIVERSIDADE DE SÃO PAULO INSTITUTO DE GEOCIÊNCIAS}
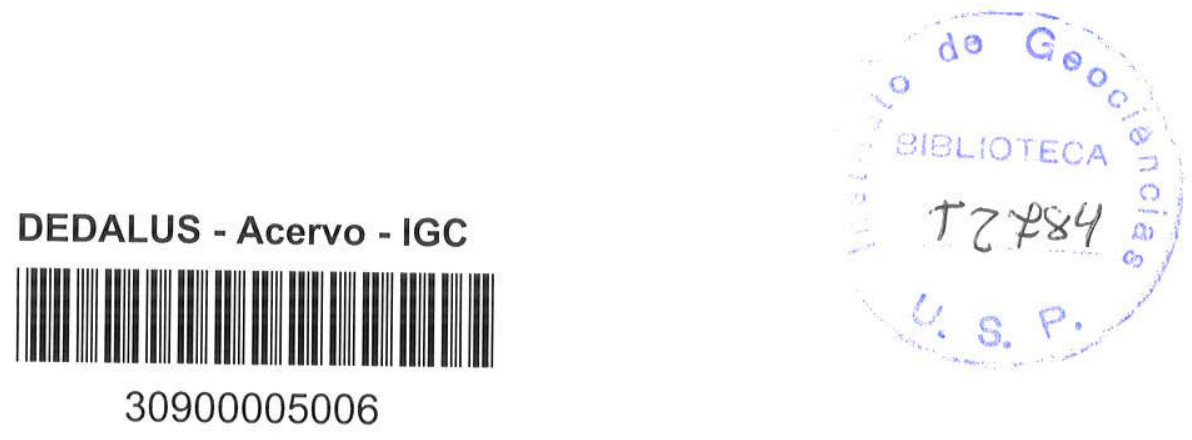

\section{AS FORMAÇÕES SUPERFICIAIS DO NOROESTE DO PARANÁ E SUA RELAÇÃO COM O ARENITO CAIUÁ}

\section{NELSON VICENTE LOVATTO GASPARETTO}

Orientador: Prof. Dr. Adilson Carvalho

\section{TESE DE DOUTORAMENTO}

Programa de Pós-Graduação em Geoquímica e Geotectônica 
Ao meu pai Máximo F. Gasparetto (in memoriun) e à minha mãe Francisquina L. Gasparetto 
ÍNDICE

AGRADECIMENTOS VII

RESUMO IX IX

ABSTRACT $\quad X I$

INTRODUÇÃO 01

CAPÍTULO I - CARACTERIZAÇÃO GERAL. DAS ÁREAS DE ESTUDO 05

1. Caracterização geológica 05

2. Relevo 13

3. Solos 15

4. Características climáticas 18

$\begin{array}{ll}\text { 5. Vegetação } & 19\end{array}$

6. Localização das áreas de estudo $\quad 21$

CAPÍTULO II - TÉCNICAS ANALÍTICAS E ABORDAGEM METODOLÓGICA 23

CAPÍTULO III - CARACTERIZAÇÃO DAS TOPOSSEQÜÊNCIAS .

1. Caracterização morfológica e micromorfológica 31

1.1. Toposseqüência do sítio Três Leões 32

1.2. Toposseqüência de Sumaré 45

1.3. Toposseqüência de Umuarama 52

2. Composição granulométrica 59

2.1. Toposseqüência do sítio Três Leões 59

2.2. Toposseqüência de Sumaré 63

2.3. Toposseqüência de Umuarama 65

2.4. Parâmetros estatísticos granulométricos de Folk \& Ward 68

2.5. A relação silte/argila 73

2.6. Análise morfoscópica 75

3. Caracterização mineralógica 81

3.1. Arenito Caiuá

3.2. Formações superficiais $\quad 85$ 
4. Minerais pesados das formações superficiais e do Arenito 90 Caiuá

4.1. Assembléia de minerais pesados das formações superficiais $\quad 91$

4.2. Distribuição dos minerais pesados das formações superficiais 93

CAPÍTULO IV - A EVOLUÇÃO DAS FORMAÇÕES SUPERFICIAIS E AS SUAS 99 RELAÇÕES COM O MODELADO E O ARENITO CAIUÁ

1. Sistema pedológico Areias Quatzosas/Latossolo Vermelho-

Escuro

2. Sistema pedológico Areias Quatzosas/Solo Podzólico

Vermelho-Escuro/Latossolo Vermelho/Escuro

3. Considerações sobre o paleoclima

102

CONSIDERAÇÕES FINAIS

BIBLIOGRAFIA

LISTA DE FIGURAS

FIGURA 1.1. Distribuição das principais unidades estratigráficas ocorrentes do estado do Paraná

FIGURA 1.2. Dados climáticos das áreas de estudo

FIGURA 1.3. Mapas de localizações e principais vias de acesso às áreas de estudo

FIGURA 3.1. Toposseqüência do sítio Três Leões

FIGURA

3.2. Toposseqüência de Sumaré

FIGURA

3.3. Toposseqüência de Umuarama

FIGURA

3.4. Distribuição vertical das frações granulométricas ao longo da toposseqüência sítio Três Leões

FIGURA 3.5. Distribuição vertical das frações granulométricas ao longo da toposseqüência de Sumaré

FIGURA 3.6. Distribuição vertical das frações granulométricas ao longo da toposseqüência de Umuarama

FIGURA 3.7. Relação entre os parâmetros estatísticos de Folk \& Ward (1957) diâmetro médio $x$ desvio padrão, diâmetro médio $x$ assimetria, diâmetro médio $x$ curtose das toposseqüências

3.8. Relação entre os parâmetros estatísticos de Folk \& Ward (1957) diâmetro médio $x$ desvio padrão, diâmetro médio $x$ assimetria, diâmetro médio $x$ curtose obtidos a partir de dados coletados no estado de São Paulo para o Arenito Caiuá (Modificado de Suarez, 1975; Landim \& Soares, 1976 e Arid et al., 1981) 
FIGURA 3.9. Freqüência (\%) de arredondamento dos grãos detríticos de quartzo das diferentes frações granulométricas encontradas nas formações superficiais e no Arenito Caiuá

FIGURA 3.10. Difratogramas de raios-x das formações superficiais

FIGURA 3.11. Difratogramas de raios- $x$ da fração argila das formações superficiais da toposseqüência sitio Três Leões

FIGURA 3.12. Difratogramas de raios- $x$ da fração argila das formações superficiais da toposseqüência de Sumaré

FIGURA 3.13. Espectroscopia de infravermelho das formações superficiais 89

FIGURA 3.14. Freqüência (\%) dos minerais pesados que ocorrem nas 97 trincheiras das várias toposseqüências

FIGURA 3.15. A relação entre freqüência e arredondamento dos minerais 98 pesados encontrados nas toposseqüências

FIGURA 4.1. Toposseqüência córrego Longe - Umuarama

FIGURA

4.2. Toposseqüência Bom Jesus - Cidade Gaúcha

FIGURA

4.3. Dados sobre as variações climáticas ocorridas durante o 114 Pleistoceno/Holoceno

\section{LISTA DAS PRANCHAS}

PRANCHA 1. Fotomicrografias (miscroscópio óptico - MO) da toposseqüência 40 do sítio Três Leões

PRANCHA 2. Fotomicrografias (MO) da toposseqüência sítio Três Leões

PRANCHA 3. Fotomicrografias (microscópio eletrônico de varredura - MEV) da toposseqüência do sítio Três Leões

PRANCHA 4. Fotomicrografias (MEV) da toposseqüência do sítio Três Leões 43

PRANCHA 5. Fotomicrografias (MEV) do Arenito Caiuá 44

PRANCHA 6. Fotomicrografias (MO) da toposseqüência de Sumaré 50

PRANCHA 7. Fotomicrografias (MEV) da toposseqüência de Sumaré 51

PRANCHA 8. Fotografias de solo e do depósito coluvial da toposseqüência de 57 Umuarama

PRANCHA 9. Fotomicrografias (MO) da toposseqüência de Umuarama

PRANCHA 10. Fotomicrografias (MEV) dos grãos detríticos de quartzo das 79 formações superficiais

PRANCHA 11. Fotomicrografias (MEV) dos grãos detríticos de quartzo do Arenito Caiuá 
PRANCHA 12 Fotografias do horizonte E com bandas onduladas e da 111 passagem do arenito para solo no sopé e no topo da vertente

LISTA DE ANEXOS

ANEXO 1 1. Dados climáticos das áreas de estudo 130

ANEXO $\quad$ 2. Sintese das descrições macro e micromorfológicas 134

ANEXO 3.Composição granulométrica e textura das formações superficiais 161

ANEXO 4. Parâmetros estatísticos granulométricos das formações 172 superficiais e do Arenito Caiuá

ANEXO 5. Minerais pesados das formações superficiais 


\section{AGRADECIMENTOS}

Ao apresentar este trabalho, desejo expressar meus sinceros agradecimentos a todas as pessoas e instituições que, de várias maneiras, colaboraram na sua execução. De modo especial, manifesto minha gratidão:

Ao Centro de Aperfeiçoamento de Professores do Ensino Superior - CAPES -, pela concessão do auxílio financeiro;

Ao Prof. Dr. Adilson Carvalho, pela orientação, cooperação, críticas e sugestões oportunas em diferentes etapas do trabalho;

À Profa. Dra. Maria Teresa de Nóbrega, pelo acompanhamento em todas as fases do trabalho, aconselhando, ensinando técnicas, discutindo resultados, analisando e criticando o texto;

Aos colegas de trabalho do Grupo GEMA, Dr. Manoel Luiz dos Santos, Dr. Sérgio Luiz Thomas, Dr. Issa C. Jabur, Dr. José Cândido Stevaux, Dr. Edvard de Souza Elias, $\mathrm{Dr}^{\mathrm{a}}$. Susana Volkmer, Ms. Deise Regina Elias, Dra. Marta de Souza, Dr. Paulo Nakashima, Dr. Valcir Carpenedo, pelos proveitosos debates, que permitiram o enriquecimento do trabalho;

Aos pós-graduandos Vanda Moreira Martins, Hélio Silveira, José Edézio da Cunha e Leonardo J. C. Santos, pela solidariedade e companheirismo nas expedições de campo;

Às técnicas de laboratório Ivaldete Barreto Gôngora e Maria de Moraes, pelo auxílio de campo, coleta, preparação e execução das análises granulométricas no laboratório do Departamento de Geografia - UEM;

Ao técnico de laboratório Helder Pinheiro Sampaio, responsável pela Microscopia Eletrônica de Varredura e pela obtenção das microfotografias no laboratório do IAG - USP;

Aos professores e colegas do Curso de Pós-Graduação, área de Geoquímica e Geotectônica, do IG - USP, pelas discussões e valiosas opiniões;

A Ana Paula, secretária do Pós-Graduação da IG-USP, pelo profissionalismo e camaradagem com que sempre fomos tratados; 
Ao zootecnista Amauri Silveira, diretor do Câmpus do Arenito, de Cidade Gaúcha, pela amizade e pelo apoio prestado durante o desenvolvimento do trabalho de campo;

Aos amigos Laércio Miguel Richter, Antônio Carlos Locatelli, Gerson Gomes, Alberto Madureira, Leide Saguti, Ivonete de Sousa, pelo carinho e amizade que muitas vezes povoaram de alegrias estes anos de trabalho;

Ao Prof. Dr. Egydio Menegotto, que foi responsável pelo meu interesse em geoquímica de superfície, pelo apoio e amizade;

Ao Prof. Dr. Carlos Leite Maciel Filho e sua esposa Lucila, que sempre me incentivaram para prosseguir na carreira docente;

Ao Prof. Dr. Jorge Alberto Villwock, da Universidade Federal do Rio Grande do Sul, pelo inestimável auxílio na descrição dos minerais pesados;

Ao Prof. Dr. André Mexias, pela execução dos trabalhos de difratometria de raios - X, da Universidade Federal do Rio Grande do Sul;

Ao Prof. Dr. Vitor Pereira, pelo auxílio na identificação dos argilominerais por espectroscopia de infravermelho;

Ao Prof. Dr. João Moreschi, que colocou à disposição o laboratório de microfotografias pertencente ao Departamento de Geologia Econômica da USP;

Ao Prof. Antônio Augusto de Assis, pela revisäo de linguagem;

Ao Curso de Pós - Graduação do Instituto de Geociências da Universidade de São Paulo, por ter-me acolhido, colocando-me à disposição toda a sua infra-estrutura, e à Universidade Estadual de Maringá, por permitir o meu afastamento e conseqüente aprimoramento científico;

Finalmente, à minha mulher Ana Maria, pelo carinho, dedicação, compreensão e incentivo que demonstrou ao longo deste trabalho, sem o que a sua conclusão seria muito mais árdua. 


\section{RESUMO}

As formações superficiais de textura arenosa que recobrem o Arenito Caiuá, na região noroeste do Paraná, têm sido consideradas como de origem coluvial e formadas durante o predomínio de climas semi-áridos desenvolvidos no Quaternário. Estudos detaihados realizados em três áreas (toposseqüências do sítio Três Leões, de Sumaré e de Umuarama) permitiram verificar suas relações com o Arenito Caiuá.

Pelas análises das toposseqüências, ficou comprovado que existe íntima relação entre a morfologia e a dinâmica da cobertura pedológica. Nas vertentes longas e pouco inclinadas, encontram-se latossolos profundos, enquanto, nas vertentes mais curtas e mais dissecadas, ocorrem solos mais rasos, que se tornam menos espessos em direção a jusante. Nos dois casos, os volumes pedológicos são concordantes com a superfície do terreno.

As análises micromorfológicas mostram que, ao longo das seqüências, ocorre transferência de matéria. $O$ desmantelamento da estrutura porfírica, que se transforma em quitônica, enaúlica e mônica pela remobilização do plasma; fissuraçăo, fragmentação e deslocamento de pequenos fragmentos de cutãs e de nódulos ferruginosos; presença de domínios, nos horizontes superiores, com perdas acentuadas de argila; dissolução do esqueleto são feições que indicam perda e remobilizações de materiais. Ao contrário, a transformação por acumulação de argila das estruturas quitônica e enaúlica em porfírica; preenchimento dos poros maiores, dando origem a cutãs; redução acentuada da porosidade, são resultantes de ganhos e reorganizações dos materiais. Essas mudanças caracterizam coberturas superficiais em transformação, pois é visivel a mudança do $B$ latossólico em $B$ textural, a partir da média alta-vertente e, deste, em areias quatzosas no final da vertente.

O quartzo é o mineral predominante tanto nos solos como no arenito sotoposto, associado com a caulinita e óxidos de ferro. A assembléia de minerais pesados é formada de minerais opacos, como hematita, magnetita, ilmenita e leucoxênio, e não-opacos, como estaurolita, turmalina, zircão e rutilo. A matriz do arenito e o plasma das formações superficiais apresentam a mesma composição química, constituída basicamente por caulinita pobremente cristalizada e por hidróxidos de ferro. 
As vertentes onde foram analisadas as toposseqüências estão relacionadas a uma superfície de erosão definida por Bigarella et al. (1965) como Pd1, a qual, desde o final do periodo Terciário, vem sendo remodelada sob condições climáticas que, durante 0 Quaternário, se alternaram entre períodos mais secos e períodos mais úmidos. Contudo, as oscilações climáticas não deixaram nesses materiais vestígios claros.

As variações laterais observadas na organização da cobertura pedológica são resultantes do recuo das cabeceiras de drenagem sobre os interflúvios e do aprofundamento dos vales. Os mecanismos que controlam esse recuo e o aprofundamento podem ser de origem climática e tectônica.

Acredita-se, portanto, que as formações superficiais ocorrentes na região noroeste do Paraná são originadas do Arenito Caiuá por alteração in situ, e que, se houve retrabalhamentos de materiais ao longo das vertentes, estes são de difícil identificação. Quando ocorrem, estão relacionados a fundos de vales, nichos de nascentes e pequenas bacias de recepção. No entanto, a mobilidade de materiais torna-se clara quando há depósitos coluviais, de origem antrópica, formados após a retirada da mata. 


\section{ABSTRACT}

The sandy surface formations that re-cover Caiua sandstone, in the northwestern area of the state of Paraná, Brazil, have been considered as of colluvial origin formed during the predominance of dry climates occurring over the Quaternary. Detailed studies carried out in the three different areas (Três Leões, in the municipality of Cianorte, Sumaré, in the minicipality of Paranavaí, and in the municipality of Umuarama toposequences) made it possibile to verify their relationship with Caiuá sandstone.

These toposequences analyses demonstrated the existence of a close relationship between the morphology and the dynamics of the pedological cover. In long and gentle slopes there are deep latosols while in shorter and steeper slopes there are shallower soils that become thinner dowstream. In both cases the pedological volumes are in harmony with the soil surface.

The micromorphological analyses showed that there occurs a transference of material along the toposequences. Porphyric struture dismantling, which is transformed into chitonic, enaulic and monic structure through plasma reworking, fissuration, fragmentation and displacement of small fragments of coatings and ferruginous nodules, presence of dominions on the upper horizons with severe losses of clay and skeleton dissolution are all forms that indicate loss and reworking of materials. On the contrary, the transformation through clay accumulation of chitonic and enaulic into porphyric struture, the fulfillment of bigger pores originating coatings and intense porosity decrease are resultant from material gain and rearrangement. These reorganizations characterize changing surface covers because the transformation of latosol $B$ into textural soil $B$, at the upper half of the slope, and then into quartzose sands, at the lower part of the slope, is visible.

Quartz is the prevailing mineral both in soil and in the underlying sandstones, associated with kaolinite and iron oxides. The assembly of heavy minerais is constituted by opaque minerals such as hematite, magnetite, ilmenite and leucoxene and transparent minerals such as staurolite, turmaline, zircon and rutile. The sandstone matrix and the plasma of the surface formations show to have the same chemical composition constituted basically by kaolinite poorly cristallized and by iron hydroxides.

The slopes in which the toposequences were analyzed are related to erosive 
surface defined by Bigarella et al. (1965) as Pd1, which from the final part of the Terciary has been remodeled under alternate dry and wet climatic conditions during the Quaternary. These climatic oscillations, however, have not left clear indices in these materials.

The lateral variations verified in pedological cover formation result from the draining slopes receding towards the watershed and from the valley deepening. The controlling mechanisms of this recession and deepening may be of climatic and tectonic origin.

It is believed, therefore, that the surface fomation verified in the northwestern area of the state of Paraná were originated from Caiua sandstone through in situ alterations and that the possible reworkings of materials along the slopes are difficult to be identified. But when occurring they are related to the foot of the valley slopes, to underground water sources and to small reception basins. But the movability of materials becomes evident when there are colluvial deposits, of anthropological origin, formed after the forest cover removal. 


\section{INTRODUÇÃO}

A região noroeste do Paraná se destaca no Terceiro Planalto paranaense pela ocorrência do Arenito Caiuá1. A essa formação geológica estão associadas formações superficiais $^{2}$ caracterizadas por solos de textura média e arenosa, derivada do arenito sotoposto, originando, de modo geral, os seguintes tipos de solos: Latossolo VermelhoEscuro, Solo Podzólico Vermeiho-Escuro, Solo Podzólico Vermelho-Amarelo, Areias Quartzosas, Solos Hidromórficos e Solos Aluviais.

A ocupação dessa região, apesar de recente (a partir da década de 1950), foi marcada por um desmatamento generalizado que expôs essa cobertura e desencadeou, de forma ampla, processos erosivos como ravinamentos, voçorocas, movimentos em massa dos solos, erosão areolar, que hoje causam muitos transtornos às comunidades e às administrações municipais e estaduais.

A erosão e o empobrecimento dos solos, associados às politicas econômicas, são os grandes responsáveis pelo êxodo rural e esvaziamento de muitas cidades da região, o que, desde 1975, tem levado a um declínio econômico acentuado. Atualmente, procuram-se alternativas para retomar o desenvolvimento econômico, buscando-se formas adequadas de produção agrícola e, principalmente, tecnologias no manejo e conservação dos solos. Em paralelo, nas zonas urbanas, onde o processo de urbanização desencadeia de forma grave os processos erosivos, principalmente as voçorocas, busca-se, além do controle dos fenômenos já desencadeados, formas de prevenção. Esses fenômenos erosivos, nas periferias urbanas, são tão intensos que levaram o Governo Estadual a criar um órgão específico para o combate e controle da erosão urbana, a SUCEAM, atualmente denominada SUDERSHA (Superintendência de Desenvolvimento de Recursos Hídricos e Saneamento Ambiental). $(1980)$.

${ }^{1}$ Neste trabalho assume-se para Arenito Caiuá a definição proposta por Soares et al.

${ }^{2}$ Formações superficiais, segundo Campy \& Macaire (1989), referem-se a um manto, móvel ou fracamente consolidado, de material decomposto ou edafizado, com espessura variável, que recobre a rocha sã. O limite entre as formações superficiais e o substrato rochoso é difícil de precisar, devido à passagem progressiva tanto na vertical como lateralmente. Quanto à origem, podem ser autóctones ou alóctones, geradas por desagregação mecânica ou alteração química. 
A partir de 1988, teve início, por intermédio de Convênio entre a SUDERSHA e a UEM (Universidade Estadual de Maringá), o desenvolvimento de pesquisa visando ao "Mapeamento Geológico-Geotécnico de Umuarama", buscando fornecer subsídios ao planejamento urbano. Em 1993, novo convênio foi firmado, tendo como objetivo a aplicação da metodologia adotada em Umuarama em outras áreas, dentro da região noroeste.

Durante o desenvolvimento desses projetos, foi possivel realizar o levantamento e reconhecimento dos principais problemas que afetam a região e que comprometem sua ocupação. Constatou-se que a sede dos fenômenos considerados como riscos são preferencialmente as formaçōes superficiais (Nóbrega et al., 1992; Gasparetto et al., 1993) e não o substrato geológico, como é geralmente enfatizado. Isto é, ambos os materiais são texturalmente semelhantes, porém seu comportamento ante os agentes erosivos é fundamentalmente diferente. O Arenito Caiuá, por sua estrutura e cimentação, mostra-se resistente à erosão, sendo para esta o nivel de base, enquanto que as formações superficiais, devido à ausência de cimentação e alta friabilidade, tornam-se extremamente susceptiveis aos processos erosivos. Assim, a chave para os mapeamentos geotécnicos e para as medidas de prevenção, nessa área, repousa sobre a natureza das formações superficiais.

Em razão das controvérsias na caracterização e dos processos geradores dessa cobertura superfícial existente na região noroeste do Paraná, propõe-se a presente pequisa, que tem como objetivos:

- o estabelecimento das relações, em termos de filiação, entre as formações superficiais (Formação Paranavaí) e o Arenito Caiuá, contribuindo para o conhecimento dos processos que atuaram no modelado da regiāo noroeste do Paraná;

- o levantamento e estudo da organização pedológica dessa cobertura, sua evolução no noroeste do Paraná, através de toposseqüências, procurando determinar sua gênese e as transformações (morfológicas, físicas e mineralógicas) ao longo das vertentes.

O conhecimento das organizações e estruturas permite o estabelecimento da sua hierarquia, auxiliando a compreensão da gênese, evolução e dinâmica dessas formações. Esses dados auxiliarão no estabelecimento das relações entre a natureza da cobertura superficial e os fenômenos erosivos, contribuindo, portanto, para o aperfeiçoamento dos 
mapeamentos geotécnicos e para as propostas de prevenção e controle de erosão.

Este trabalho foi desenvolvido com o objetivo de se buscar resposta a algumas questões abordadas anteriormente, bem como contribuir para a evolução do conhecimento científico sobre as formações superficiais da região noroeste do Paraná. Para alcançar os objetivos propostos, foram desenvolvidas diversas etapas, como: trabalho de campo, revisão bibliográfica de trabalhos precedentes e análises de laboratório. A seguir são apresentados, de forma simplificada, os diversos capítulos que compõem este trabalho.

No capitulo /, denominado Caracterização geral das áreas de estudo, são descritas, de forma sucinta, as características do meio natural que exercem importante papel nos fenômenos anteriormente citados, minimizando ou acelerando os processos relacionados à degradação ambiental da região. Nesse capítulo são discutidos a geologia das áreas, descrevendo a rocha e as formações superficiais, o clima que atua sobre esses materiais, o relevo e a vegetação.

No capitulo II, sob a denominação Técnicas analiticas e abordagem metodológica, apresenta-se a descrição dos métodos e das técnicas empregados para alcançar os objetivos desta pesquisa. Busca-se, portanto, dar suporte ao leitor para as discussões que serão abordadas durante o transcorrer do trabalho.

Sob o título de Caracterização das toposseqüências, desenvolve-se o capítulo III, - qual apresenta as descrições das análises morfológicas, micromorfológicas, granulométricas e mineralógicas. A partir dos resultados das análises granulométricas, foi discutida a distribuição das frações no perfil e ao longo da seqüência $e$, também, foram calculados os parâmetros estatísticos granulométricos de Folk \& Ward (1957). Esses dados são importantes para se tentar elucidar os aspectos relacionados à filiação das formações superficiais com o Arenito Caiuá sotoposto. São descritas, também, as características morfológicas de todos os horizontes que ocorrem em cada toposseqüência, salientando a textura, cor, transição de um volume a outro, além das principais feições pedológicas presentes. Junto com a morfologia, são apresentadas as principais características micromorfológicas dos horizontes, nas escalas microscópica e ultramicroscópica. A aplicação de diferentes técnicas de análise permite observações detalhadas dos constituintes, principaimente da superfície do esqueleto, além de ilustrar as diferentes fases 
mineralógicas que compõem os materiais que constituem as formações superficiais e o Arenito Caiuá.

A caracterização mineralógica apresenta os dados mineralógicos do Arenito Caiuá e das formações superficiais, descrevendo as características das principais espécies de minerais, salientando a assembléia dos minerais pesados, que são importantes agentes no estudo de proveniência de materiais.

No capitulo IV, denominado $A$ evolução das formações superficiais e as suas relações com o modelado e o Arenito Caiuá, procura-se descrever as transformações das formações superficiais, observadas ao longo das vertentes, além de apresentar-se uma síntese do paleoclima. Procura-se integrar os resultados da micromorfologia, mineralogia e dos minerais pesados. Nesse capítulo são enfatizados todos os aspectos relacionados com a evolução das formações superficiais, das áreas de pesquisas, e sua filiação com o Arenito Caiuá sotoposto.

Nas Considerações finais, faz-se um apanhado geral do trabalho, salientando-se as constatações observadas e as conclusões alcançadas.

As referências bibliográficas são listadas no final do trabalho em ordem alfabética.

Como Anexos, são relacionados, também no final do trabalho, os dados referentes às formações superficiais e ao Arenito Caiuá, na forma de Tabelas, algumas obtidas de dados bibliográficos de diversos autores, e também das descrições morfológica e micromorfológica, na forma de Quadro. Esses dados serviram para dar suporte às discussões apresentadas. 


\section{CAPÍTULO I}

\section{CARACTERIZAÇÃO GERAL DAS ÁREAS DE ESTUDO}

As áreas de estudo selecionadas para esta pesquisa, Cianorte, Paranavaí e Umuarama, estão inseridas na região noroeste do estado, em um setor do Terceiro Planalto paranense (Maack,1953), correspondendo a áreas onde os derrames vuicânicos estão capeados pelos arenitos da Formação Caiuá (Fig.1.1). O Arenito Caiuá encontra-se praticamente todo encoberto por uma espessa camada arenosa proveniente do próprio arenito, mas foi descrita por Popp \& Bigarella (1975) como de origem colúvio-aluvionar, com a denominação Formação Paranavaí. A seguir serão descritos os principais aspectos responsáveis pelas características físicas das áreas de estudo.

\section{Caracterização geológica}

A seqüência de derrames basálticos sotoposta ao Arenito Caiuá está relacionada a um intenso vulcanismo fissural, que foi o responsável pela ruptura do continente do Gonduana e deu origem a intensos platôs que atualmente se encontram profundamente dissecados pelos processos de intemperismo.

As litologias originadas por esses derrames foram definidas como Formação Serra Geral por White (1908), e sua maior espessura encontra-se próximo à calha do rio Paraná, onde a Petrobrás perfurou $1.530 \mathrm{~m}$ de rochas vulcânicas, permitindo a individualização de 33 derrrames (Sanford \& Lange, 1960).

Estudos sobre petrologia e geoquímica, desenvolvidos principalmente na década passada, possibilitaram um melhor entendimento do quimismo e da dinâmica responsáveis pelas fabulosas manifestações vulcânicas (Sartori \& Gomes, 1980; Bellieni et al., 1983, 1984, 1986; Comin-Chiaramonti et al., 1983; Fodor et al., 1985; Corwin et al., 1986; Fodor, 1987; Piccirillo et al., 1987).

De modo geral, na Formação Serra Geral ocorrem dois tipos de lavas. Na porção 
basal predominam as lavas básicas (basaltos), enquanto nas porções superiores destacam-se as lavas ácidas (riolitos e riodacitos), distribuídas preferencialmernte nas porções central e sudeste da bacia (Sartori et al., 1975; Bellieni et al., 1983, 1984, 1986).

Embora os diferentes tipos de materiais expelidos, as rochas apresentam uma composição mineralógica simples, formada na sua maior parte por plagioclásios, piroxênios, anfibólios, opacos, quartzo e vidro (Ruegg, 1969; Sartori \& Gomes, 1980; Menegotto \& Gasparetto, 1987; Gasparetto, 1991).

Nas áreas de estudo, essas rochas ocorrem como soleiras e/ou como diques de diabásio, no fundo das drenagens, com direção NW.

Assentando-se de forma discordante sobre os basaltos da Formação Serra Geral, ocorrem os arenitos da Formação Caiuá, que predominam na região noroeste do Parana. Esses arenitos foram inicialmente descritos por Baker (1923), porém quem os definiu como unidade litoestratigráfica foi Washburne (1930), denominando-a Formação Caiuá. No entanto, desde a sua proposição, o Arenito Caiuá obteve, por parte dos pesquisadores, várias interpretações, principalmente quanto à idade, espessura, gênese e posição estratigráfica. Essas divergências têm surgido na medida em que novos trabalhos desenvolvidos vão expondo diferentes pontos de vista, na maioria das vezes contraditórios.

Maack (1941) foi o primeiro pesquisador a realizar um amplo trabalho sobre o Arenito Caiuá na região noroeste do estado do Paraná. Além de aceitar a existência da unidade, confirma a definição proposta por Washburne (1930).

Gordon Jr. (1947) estuda o Arenito Caiuá e ratifica as proposições de Maack (1941) quanto à origem dessa unidade litoestratigráfica. Para o autor, o Arenito Caiuá seria uma continuidade física dos sedimentos existentes sob os basaltos, pertencentes à Formação Botucatu.

Afora algumas discrepâncias de idéias, parece haver consenso no que diz respeito à composição mineralógica e às estruturas existentes. Assim, a Formação Caiuá é constituída predominantemente de arenitos finos a muito finos, apresentando cores que variam do vermelho-arroxeado a vermelho-escuro, com pequenos teores de matriz lamítica. Entretanto, niveis ou lentes de material mais fino foram descritos, apesar de raros e de ocorrência bastante localizada. Embora a grande uniformidade litológica, o que é uma 
das características dessa formação, o mesmo não acontece em termos granulométricos. Riccomini et al. (1981) observaram e descreveram que nos bancos com estratificação cruzada e suborizontal predominam arenitos finos a médios com bom grau de seleção, enquanto nos bancos com estrutura maciça ocorrem arenitos finos mal selecionados, geralmente com várias modas associadas.

O arredondamento dos constituintes do Arenito Caiuá é bom e não apresenta grandes diferenças, porém existe uma leve tendência de os grãos maiores apresentarem grau de arredondamento mais elevado (Suarez, 1975; Arid et al., 1981; Riccomini et al.,1981). Essa diferença de arredondamento observada nos grãos pode estar relacionada a ciclos de deposição diferentes para tais sedimentos (Freitas, 1973).

A maior parte dos trabalhos analisados dá pouca importância à composição mineralógica do Arenito Caiuá. Entre os que demostram maior interesse, destacam-se Suarez (1975), Coimbra (1976), Suguio (1980), Fernandes (1992), Fernandes et al. (1994).

Em geral, o Arenito Caiuá apresenta como constituinte essencial o quartzo, que varia de $75 \%$ a $90 \%$ do total da rocha; secundariamente, aparecem os feldspatos (microclínio e plagioclásios), com teores compreendidos entre $5 \%$ e 10\%, além de, mais raramente, calcêdonia e muscovita. Também é freqüente a presença de fragmentos líticos, principalmente de basalto alterado, folhelhos, arenitos, siltitos e sílex; nunca, porém, ultrapassando $10 \%$.

Quanto aos argilominerais, Fernandes (1992) e Fernandes et al. (1994) identificaram esmectitas, que predominam nas amostras de profundidade, e caulinita, nas amostras superficiais coletadas em afloramentos. A illita também ocorre, mas de forma subordinada.

Associados a esses minerais, ocorrem também minerais pesados, destacando-se a presença de turmalina, zircão e estaurolita, o que mostra uma alta maturidade mineralógica. Em segundo plano, aparecem rutilo, cianita, granada e monazita. Entre os opacos, temos leucoxênio, ilmenita, hematita e magnetita. Todos esses constituintes estão agregados por cimento silicoso, carbonático, ferruginoso e argila.

Nessa formação, é comum a presença de cimento carbonático, que está disseminado por todo o pacote, mas sendo mais freqüente na porção basal. Segundo Suguio (1980), dificilmente atinge $10 \%$, a não ser em casos esporádicos, quando ocorre 
a presença de pequenos nódulos calcários, que podem atingir $40 \%$ do total da rocha (Riccomini et al., 1981). Associados, podem ocorrer hidróxidos de ferro, argila e silicificação desenvolvida através do intercrescimento secundário de grãos de quartzo, os quais, quando presentes em abundância, conferem elevado grau de resistência à rocha.

A existência de níveis com fragmentos de basalto, na base da Formação Caiuá, já fora observado por Washburne (1930), que acreditava serem decorrentes de fissuras presentes nas lavas, posteriormente preenchidas por arenitos transportados pelos ventos. Concordava com essa hipótese Maack (1941). Porém a grande maioria dos pesquisadores afirma que o contato basal do Arenito Caiuá com as lavas básicas da Formação Serra Geral é discordante. Inclusive descrevem a presença de paleossolo juntamente com fragmentos de basalto e calcedônia, o que indicaria que o basalto esteve exposto por longo tempo, sujeito a processos de alteração intempérica, antes da deposição do arenito (Soares et al., 1979, 1980; Riccomini et al., 1981; Jabur \& Santos,1984; Bigarella \& Mazuchowski,1985).

As estruturas freqüentemente encontradas na Formação Caiuá são bancos individualizados de dimensões variadas, que geralmente exibem estratificação cruzada suborizontal. Estratificações cruzadas acanaladas e tabulares, de médio a grande porte e tangenciais na base, são as mais comuns. Canais de corte e preenchimento e dobras convolutas podem também estar presentes.

Segundo Fernandes (1992) e Jabur (1992), o arco de Ponta Grossa e as estruturas por ele formadas, com direção preferencial NNE, exerceram forte controle estrutural na deposição do Arenito Caiuá no Cretáceo superior, sendo gerados dois locais de deposição com alinhamento NE-SW, praticamente coincidindo com a calha principal da bacia do rio Paraná, situados ao norte e ao sul do alto estrutural do pontal de Paranapanema.

Na região em que foi realizado este trabalho, existem dois locais onde o Arenito Caiuá encontra-se intensamente silicificado e fraturado: Três Morrinhos, próximo à cidade de Porto Rico, e o morro dos Três Irmãos, próximo a Terra Rica. Para Jabur \& Santos (1984), a orientação desses fraturamentos é coincidente com a direção preferencial dos diques de diabásios, comuns no estado, e a silicificação foi atribuida, pelos autores, a processos hidrotermais pós-cretáceos. Atualmente, essas localidades destacam-se como altos topográficos em relação às áreas circunvizinhas, e seus topos retilinizados 
corresponderiam a restos preservados de uma superfície de aplainamento desenvolvida no Terciário inferior, equivalente à Sul Americana de King (1956).

Sobre o Arenito Caiuá ocorrem espessas formações superficiais de textura arenoargilosas. Esses depósitos, de composição predominantemente arenosa com silte e argila, com ou sem a presença de cascalhos na base, são há muito tempo citados na literatura geológica. Os materiais que compõem essa cobertura podem, às vezes, ser semelhantes às rochas sotopostas, ou mesmo alterações destas (Cottas \& Barcelos, 1981). Quando isso ocorre, fica difícil separar essas litologias das rochas sotopostas. Nesses casos, devem ser levadas em consideração as características da litologia, posição estratigráfica e agregação dos materiais. Quando existe uma superficie erosiva ou uma linha de seixos, a separação é facilitada.

Mezzalira \& Arruda (1965) descrevem uma vasta cobertura arenosa, existente na região do pontal do Paranapanema, de idade mais jovem se comparada com a Formação Bauru.

Estudos realizados por Landim \& Fulfaro (1971), sobre arenitos pertencentes ao Grupo Bauru, tecem comentários a respeito de sedimentos mais jovens que as rochas sotopostas, provavelmente pertencentes a ciclos sedimentares mais recentes. Estão separados das Formações Caiuá e Bauru por níveis de fragmentos de limonita e cascalhos na base desses depósitos, gerados após a deposição do Grupo Bauru.

Soares et al. (1973) não só confirmam a existência dessa cobertura arenosa, como a dividem em termos de idade e também quanto à sua origem. A unidade mais antiga corresponderia aos depósitos residuais preservados, que teriam sido gerados durante a elaboração da superfície Sul-Americana (King, 1956). A outra unidade de idade terciária estaria representada na forma de patamares existentes ao longo dos principais vales e escarpas da região.

Soares \& Landim (1976) classificam os depósitos cenozóicos, quanto à sua localização, em três tipos: os que ocorrem sobre altos interflúvios, os desenvolvidos nos médios interflúvios e os baixos terraços. Para classificar tais depósitos, foram tomadas como base a superfície Sul-Americana de King (1956), além de outros elementos, como o soerguimento continental, variação do nível de base, condicionantes tectônicas, litológicas e variações climáticas. 
Popp \& Bigarella (1975) descreveram os depósitos arenosos que recobrem o Arenito Caiuá e apontaram a existência de uma superfície de erosão entre eles, a qual é melhor indentificada no fundo de voçorocas que ocorrem nos municípios de Cianorte e Paranavaí. Como esses materiais assentavam-se de forma discordante sobre o Arenito Caiuá e eram passiveis de mapeamento, foram então designados formalmente como Formação Paranavaí. Esses autores fazem referência a várias seqüências de areias de aspecto coluvial ou aluvial, ressaltando que muitas vezes torna-se difícil distinguir entre 0 manto de intemperismo e os sedimentos cenozóicos da Formação Paranavaí, aparentemente desprovidos de estruturas primárias.

A ocorrência de sedimentos bastante diferenciados, quando comparados aos das Formações Caiuá e Bauru, não passou despercebida quando Suarez (1976) realizou trabalhos na região do pontal do Paranapanema. Durante suas pesquisas, 0 autor percebeu para aqueles depósitos arenosos e friáveis a presença de pequena atividade diagenética, desenvolvimento de crostas lateríticas, de cascahos e até de conglomerados, além de uma superfície erosiva, desvinculando, dessa forma, esses depósitos das formações sotopostas.

Almeida et al. (1980) também efetuaram trabalho de cunho regional no pontal do Paranapanema, e todos aqueles depósitos suspensos em relação ao nivel de base atual da região foram definidos como depósitos cenozóicos. Entre esses depósitos, destacam-se as cascalheiras, colúvios pré-atuais, bem como colúvios e alúvios atuais. A exceção ocorre quando os aluviões estão associados às drenagens atuais. Nesse trabalho, não fazem comentários quanto ao contato com as formações sotopostas.

Dehira et al. (1981), em estudos realizados no noroeste do Paraná, principalmente entre os municípios de Paranavaí e Cianorte, identificaram vários tipos de depósitos de idade cenozóica (cascalheiras fluviais subatuais alçadas, aluviões entalhados subatuais alçados, complexos colúvio-aluvionares subatuais restritos, coluviões arenosos a arenoargilosos, aluviões em terraços e aluviōes atuais). Todos esses depósitos estariam reiacionados a flutuações climáticas do Quaternário, associadas a soerguimentos epirogenéticos de idade pós-pliocênica.

Os depósitos que formam uma delgada cobertura sobre as Formações Caiuá e Bauru, em altitudes que variam em torno de $600 \mathrm{~m}$, foram considerados como depósitos remanescentes da superfície Sul-Americana por Suguio (1980). Ainda segundo esses 
autores, muitas vezes esses sedimentos avermelhados são confundidos com solos oriundos do próprio Arenito Caiuá.

Para Azevedo \& Mazzoli (1984), os depósitos cenozóicos englobam sedimentos de idades diferentes, desde o Terciário até o Recente, uma vez que capeiam de forma indiscriminada superficies erosivas antigas, como aquela desenvolvida sobre sedimentos do Subgrupo Itararé, na região de Aguaí-SP. Esses depósitos não apresentam estruturas visíveis e estariam associados a espigões com altitudes que variam de $640 \mathrm{~m}$ a $720 \mathrm{~m}$.

Melo et al. (1997) descrevem as delgadas coberturas areno-argilosas neocenozóicas como de origem colúvio-eluvial, e o principal critério, se não o único, para tal afirmação, seria a existência de um nível basal constituido por material grosseiro, indicando, nesse caso, uma origem alóctone para tais coberturas.

Hipótese diferente é preconizada por Vaz (1997), salientando que depósitos coluvionares estão geraimente associados a escarpas, de média a alta declividade, recobertas por solos residuais. Os solos residuais dos topos das vertentes tenderiam a movimentar-se encosta abaixo, depositando-se no fundo dos vales. O processo tem início com a formação de uma escarpa e se prolonga ao longo desta. Isso, segundo o autor, explicaria a presença de grandes áreas planas recobertas por material coluvial.

Para Muratóri (1997), essas coberturas areno-argilosas entraram em desequilíbrio, principalmente após o desmatamento. A retirada da mata que as protegia submeteu a região a uma ação anômala de energia, sob condiçōes do clima atual, semelhante àquelas impostas no passado sob condições de clima seco. Com isso, antigas acumulações de areia em processo de evolução pedogenética passaram a sofrer ação de fenômenos de erosão. Esse processo torna-se mais evidente quando associado a condições geológicas especiais, como alinhamentos tectônicos.

Junto às margens dos principais rios que drenam a região noroeste ocorrem depósitos recentes, na forma de terraços, com dimensões e espessuras variadas, estando sempre situados acima das planícies de inundação atual. Esses depósitos geralmente encontram-se dissecados, o que favorece a observação direta da interface desses depósitos com a Formação Caiuá, denunciando o caráter discordante entre ambos.

A partir da superfície erosiva, pode ocorrer uma camada de espessura variável de conglomerado que grada para uma granulometria mais fina em direção ao topo. Sobre o 

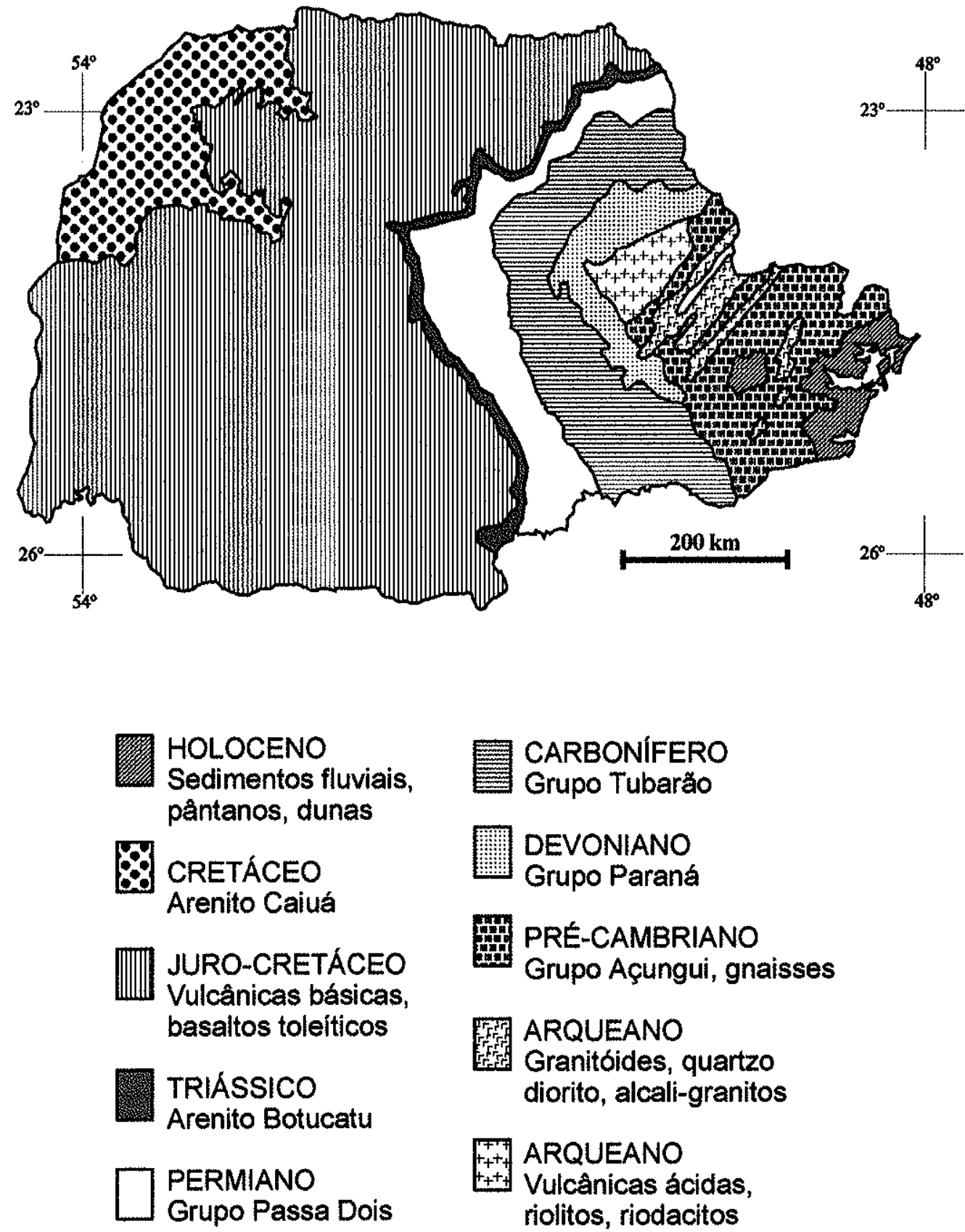

PRÉ-CAMBRIANO
Grupo Açungui, gnaisses

Fre

HEr diorito, alcali-granitos

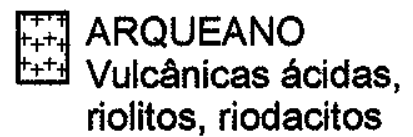

Fig. 1.1. Distribuição das principais unidades estratigráficas ocorrentes no estado do Paraná (Mineropar, 1986) 
pacote desenvolvem-se camadas areno-argilosas, que, após intalados os processos pedogenéticos, tendem a uma homogeneização, ficando bem visíveis somente os materiais mais grosseiros. Durante a evolução da pedogênese, e também em razão da variação do nível freático, desenvolvem-se no meio dos materiais dos solos pequenos nódulos ferruginosos. Níveis de conglomerados agregados com cimento limonítico são freqüentemente encontrados junto ao leito das maiores drenagens da região. Quanto mais distantes das margens essas linhas de nódulos se encontram, e quanto mais acima estão do nível de base da região, maior a possibilidade de serem confundidas com superfícies erosivas. Esses terraços são comuns ao longo do rio Ivaí.

Nas drenagens menores, é comum se encontrar pequenos depósitos inconsolidados, formados por mistura de seixos, areias, silte e argila de cor variada, geralmente em tons claros. Na maior parte das vezes, esses materiais são provenientes diretamente do Arenito Caiuá e dos materiais colúvio-aluvionares existentes ao longo das vertentes. Quando a drenagem se desenvolve sobre os basaltos, estes também passam a contribuir para a formação de tais depósitos. Noutros casos, podem ser encontradas cascaiheiras atuais, provenientes do retrabalhamento de depósitos mais antigos.

\section{Relevo}

Na região do Terceiro Planalto paranaense, na área de ocorrência do Arenito Caiuá, o relevo apresenta-se uniforme e pouco dissecado. É caracterizado por extensos espigões levemente ondulados, com vertentes convexas, longas e de baixa declividade.

Na maior parte desse relevo, as altitudes variam de 550m, na região de Paranavaí, a $300 \mathrm{~m}$, nas margens dos rios Paraná e Paranapanema. Em determinados locais, onde a rede de drenagem está mais entalhada, ou nas cabeceiras dos principais rios, o relevo torna-se mais dissecado, exibindo colinas em forma de meia laranja, vertentes convexas e desniveis que podem ultrapassar a $50 \mathrm{~m}$.

A paisagem monótona do relevo regional somente é interrompida pelos afloramentos de arenito silicificado, o que permite o aparecimento de morros testemunhos, como o morro dos Três Irmãos e os Três Morrinhos. Nesses locais, as vertentes são abruptas, com a presença de colúvios, intenso fraturamento e um nítido alinhamento para 
NW, direção que coincide com a dos diques de diábasio da Formação Serra Geral. Igualmente, ocorrem em determinados locais da região, mais precisamente no morro da Telepar, em Umuarama, colinas que se sobressaem na paisagem devido à presença de carapaças ferruginosas endurecidas que atingem $60 \mathrm{~cm}$ de espessura.

De modo geral, a região noroeste apresenta um relevo suavizado pouco ondulado, com vertentes predominantemente convexas. Associadas a essas formas, desenvolvem-se colinas alongadas com topos arredondados, planos ou convexos pouco marcados.

A região noroeste do Paraná, a exemplo de grande parte do território brasileiro, deve o seu aspecto morfológico atual à alternância de processos morfogenéticos relacionados a diferentes sistemas morfocilimáticos recorrentes (em razão das oscilações climáticas do Cenozóico) que se instalaram sobre um arcabouço morfo e geoestrutural do final do Cretáceo, submetido a epirogênese positiva (Bigarella \& Mazuchowski, 1985).

Durante o Terciário, de acordo com Ab'Sáber (1960) e Bigarella et al. (1965), processos morfogenéticos ligados ao sistema morfoclimático semi-árido rigoroso elaboraram modelados de aplainamento de extensão regional, originando as superfícies de cimeira e as interplanálticas. Essas superfícies estariam representadas nas regiões norte e noroeste do Paraná, além de um pediplano "beira-rio" (Justus, 1985).

Os processos de pedimentação que originaram essas superfícies, segundo Justus (1985), dificilmente podem ser observados, devido aos retrabalhamentos posteriores aliados aos recobrimentos dessas superfícies por formações superficiais, que em alguns casos podem atingir mais de $20 \mathrm{~m}$ de espessura. Tais depósitos apresentam-se pedogeneizados, formando latossolo vermelho-escuro, latossolo roxo e areias quartzosas.

Em niveis mais baixos, surge um compartimento de "beira-rio", originado por um entalhe vertical da drenagem e um posterior alargamento por degradação lateral, que atuaram sobre as rochas da Formação Caiuá, gerando uma superfície aplanada. Essa superfície apresenta-se também recoberta por formações superficiais pedogeneizadas, formando solos podzólicos vermelho-escuros nas áreas de acumulação e latossolo vermelho-escuro nas demais áreas (Justus, 1985).

Feições como pedimentos, superfícies de erosão, depósitos rudáceos, terraços e planícies aluviais, vistas como produtos específicos de processos climáticos pelos 
autores anteriormente citados, são questionadas por Mendes (1984) e Ross (1991), pela não- associação daquelas feições com as condicionantes tectônicas. Para Ross (1991), as alterações climáticas precisam ser extremamente prolongadas para exercer algumas modificações sobre $o$ arcabouço estrutural das grandes formas de relevo. Ainda segundo esse autor, os climas que atuaram no passado não deixaram bons testemunhos, e climas tropicais úmidos tendem a apagar esses vestígios, pela ação intensa dos processos de alteração e de pedogênese.

Além das condicionantes tectônicas, devem ser acrescentados os processos de alteração química e a pedogênese. Mesmo porque os autores citados anteriormente, com exceção de Ross (1991), somente se preocuparam com a forma, esquecendo-se dos materiais que constituem essas feições. Cabe salientar também que, durante vários anos de estudos realizados por pesquisadores e alunos de pós-graduação (Cunha et al., 1990; Cunha, 1996; Nóbrega et al., 1992; Gasparetto et al., 1993; Martins, 1994; Martins et al. 1998; Cunha \& Nóbrega, 1998) da Universidade Estadual de Maringá, nunca ficaram claros a provável origem e o modo de transporte dessa cobertura.

Por outro lado, existe uma vasta bibliografia que relaciona o modelado com processos de alteração química e pedogênese (Delvigne, 1965; Tricart, 1965; Thornbury, 1966; Buol et al.,1973; Boulet, 1978; Leprun,1979; Millot et. al.,1979; Lucas,1989; Filizola, 1993; Ruellan \& Dosso, 1993), toda ela chamando atenção para a estreita associação das formas de relevo com os processos de alteração supérgena e com a pedogênese, em diferentes partes do mundo.

\section{Solos}

Os solos que se desenvolvem sobre o Arenito Caiuá apresentam textura média e arenosa e são extremamente friáveis. O substrato geológico, associado ao clima da região, deu origem a formações superficiais representadas, predominantemente, por solos bem-desenvolvidos, profundos. O Latossolo Vermelho-Escuro ocorre em áreas de relevo suave, ondulado a praticamente plano (topos e altas vertentes); o Solo Podzólico Vermelho-Escuro predomina nas médias e baixas vertentes, ocorrendo também em alguns casos nas partes altas das vertentes de maior declividade. No terço inferior das vertentes 
ocorrem Areias Quatzosas e eventualmente solos Litólicos quando as declividades são acentuadas. A textura mais arenosa nos volumes superficiais tona-os bastante suceptíveis à erosão (Ministério da Agricultura, 1970; Cunha et al. 1990; Gasparetto et al., 1993; Cunha, 1996; Cunha \& Nóbrega, 1998).

O mapa de solos elaborado durante o levantamento de campo (Mapeamento geotécnico e estudos dos fenômenos erosivos na região noroeste do Paraná) Gasparetto et al. (1993) identificou a distribuição de diferentes classes de solos, em nível de grupo e subgrupo, de acordo com a classificação proposta pela Embrapa-lapar (1984), cuja descrição esquemática é apresentada a seguir:

- Latossolo Vermelho-Escuro textura média: compreende os solos com horizonte B latossólico, que ocorrem nos espigões e principais divisores de água, como no distrito de Sumaré (Paranavaí), próximo à torre da Copel (Cianorte) e junto ao trevo de acesso a Maria Helena (Umuarama), em altitudes próximas de $500 \mathrm{~m}$, em posições de topos e alta vertente, com declividades sempre inferiores a 5\%. São originários do Arenito Caiuá, profundos (>300cm), com seqüência de horizontes $\mathrm{A}$ ou $\mathrm{Ap}, \mathrm{Bw}_{1}, \mathrm{Bw} w_{2}$ e C, com transição difusa. O horizonte $A$ apresenta, freqüentemente, textura areno-franca a franco-arenosa, com teores de argila variando de $5 \%$ a $15 \%$ e areia fina entre $30 \%$ e $75 \%$, espessura entre $10 \mathrm{~cm}$ e $60 \mathrm{~cm}$, estrutura maciça a granular pequena, fraca; consistência úmida muito friável, não plástica, não pegajosa; coloração variando de 2,5YR 3/6 a 5YR 4/6 (vermelho-escura a vermelho-amarelada). O horizonte B é espesso e apresenta textura franco-arenosa a franco-argilo-arenosa, com teores de argila variando de $15 \%$ a $22 \%$ e areia fina entre $30 \%$ e $75 \%$; estrutura em blocos subangulares a granulares, fraca; consistência úmida friável, ligeiramente plástica a ligeiramente pegajosa e coloração 2,5YR $3 / 6$ - 4/8 (vermelho-escura a vermelha);

- Solo Podzólico Vermelho-Escuro textura arenosa/média: aparece, normalmente, em relevos de vertentes convexas, como a da toposseqüência do sítio Três Leões, com declividades ligeiramente mais acentuadas, principalmente em posições de média-baixa vertente. Esse tipo de solo apresenta espessuras de $150 \mathrm{~cm}$ a $250 \mathrm{~cm}$ e uma sequência de horizontes $\mathrm{A}$ ou Ap, E, Bt e C com transição clara entre os horizontes $\mathrm{E}$ e Bt. Os horizontes superficiais ANAp possuem espessura que pode variar de $10 \mathrm{~cm}$ a $60 \mathrm{~cm}$; coloração geralmente 5YR 4/6 (vermelho-amarelada), textura arenosa a areno-franca com teor de argila às vezes inferior a $7 \%$ e areia fina entre $42 \%$ e $85 \%$; estrutura 
granular muito pequena e fraca. O horizonte $E$ é lavado, mais claro, essencialmente arenoso, estrutura maciça quando úmido a grãos soltos quando seco, com porcentagem de argila inferior a $6 \%$. O horizonte Bt apresenta espessura de $30 \mathrm{~cm}$ a $120 \mathrm{~cm}$; cor $2,5 \mathrm{YR}$ 3/6 - 4/8-5/8 (vermelho-escura a vermelho-amarelada); estrutura poliédrica subangular fraca a moderadamente desenvolvida; a cerosidade raramente aparece envolvendo os agregados do horizonte $\mathrm{Bt}$ e, quando existente, é fraca a moderada (TR-III da toposseqüência do sítio Três Leões). A consistência úmida é friável, ligeiramente plástica a plástica e ligeiramente pegajosa a pegajosa quando molhada. Nesse horizonte, a permeabilidade é reduzida, em relação aos horizontes arenosos superficiais;

- Areias Quartzosas: aparecem, normalmente, nos setores de baixa vertente, como no final das toposseqüência de Sumaré e do sítio Três Leões, sendo caracterizadas por um horizonte A espesso, superior a $100 \mathrm{~cm}$, constituido predominantemente por grãos detríticos de quartzo esbranquiçados, textura arenosa a areno-franca, estrutura de grãos soltos quando secos e cor 10YR 4/2 - 6/6 (vermelho-acinzentada a vermelho-clara). 0 horizonte C apresenta, na maioria das vezes, tons avermeihados ou brancoacinzentados e textura ligeiramente mais argilosa, podendo apresentar características de um horizonte B incipiente. Quando isso ocorre, assemelham-se ao latossolo;

- Cambissolos e os solos Litossolos: identificados como solos rasos durante o levantamento de solo, normalmente ocorrem nas áreas de relevo mais dissecado, em geral no setor inferior das vertentes, próximo ao fundo do vale dọs principais eixos de drenagens. Esses solos são pouco espessos, geralmente inferiores a $100 \mathrm{~cm}$, com seqüência de horizontes $A, B i, C, R$ e $A, C$ e $R$, respectivamente; de textura arenosa a franco-arenosa;

- solos Hidromórficos: localizam-se freqüentemente nas áreas deprimidas e nas proximidades de pequenas várzeas, principalmente ao longo das margens dos córregos, onde o relevo torna-se praticamente plano. Caracterizam-se pela má-drenagem, pois permanecem por longos períodos do ano sob a influência do lençol freático, promovendo os fenômenos de oxidação e redução e dificultando a decomposição da máteria orgânica. Esses processos conferem ao solo uma coloração variada e textura normalmente arenosa, ao menos na superfície;

- solos Aluviais: esses solos foram mapeados nas margens das drenagens mais importantes. Geralmente, são formados por depósitos estratificados, com intercalação 
de areia grossa e de materiais mais finos, apresentando coloração e espessura variadas. São comumente encontrados junto às margens do córrego Catingueiro, no município de Cianorte;

- foram agrupados como depósitos coluviais os materiais remanejados pelo escoamento superficial ao longo das vertentes e depositados nos vales em berço e cabeceiras de drenagens, após a retirada da mata e ocupação da área. Correspondem a depósitos com espessura variada entre $100 \mathrm{~cm}$ e $250 \mathrm{~cm}$, com sucessão de estratos, paralelos ou não, $\mathrm{com} 10 \mathrm{~cm}$ a $30 \mathrm{~cm}$ de espessura, textura arenosa a franco-argilo-arenosa. Às vezes aparecem, associadas a esses depósitos, lentes argilosas, centimétricas, de cor avermelhada. É comum encontrar nesses depósitos alternância de camadas arenosas com granulometria bem diferenciada.

\section{Características climáticas}

Para caracterizar as particularidades climáticas das áreas de estudo foram selecionadas as estações metereológicas mais próximas, obtendo-se dados referentes à temperatura e precipitação. Os dados foram coletados no Instituto Agronômico do Paraná - lapar - Londrina. Analisando-se os gráficos da Fig. 1.2 e os dados do Anexo 1, verifica-se que não há diferenças significativas entre as temperaturas médias mensais registradas em Cianorte, Paranavaí e Umuarama. Os meses com as mais baixas médias mensais, entre $17^{\circ} \mathrm{C}$ e $20^{\circ} \mathrm{C}$, são junho, julho e agosto, que correspondem ao inverno. Nos meses de dezembro, janeiro e fevereiro são encontradas as mais altas médias mensais, entre $24^{\circ} \mathrm{C}$ e $25^{\circ} \mathrm{C}$, correspondendo ao período de verão. Entretanto, observa-se que as diferenças mais significativas ocorrem entre os valores das médias mensais das temperaturas máximas e mínimas ocasionadas pelas muđanças das estações do ano e pela variação diária da temperatura.

Em todos os meses, a amplitude térmica das três áreas é superior a $24^{\circ} \mathrm{C}$, podendo ultrapassar $35^{\circ} \mathrm{C}$. Na região de Paranavaí, ao longo do ano, a amplitude térmica média pode ultrapassar $44^{\circ} \mathrm{C}$. Esses dados confirmam um clima com extrema variação de temperatura, quando as máximas absolutas podem ultrapassar $41^{\circ} \mathrm{C}, \mathrm{com}$ mínima absoluta em torno de $-3.0^{\circ} \mathrm{C}$. 
Quando relacionadas as temperaturas mínimas absolutas, verifica-se que há pequenas diferenças de valores para as três áreas. Em Paranavaí e Cianorte, as mínimas absolutas, para o periodo analisado, foram de $-3,0^{\circ} \mathrm{C}$ e $-2,4^{\circ} \mathrm{C}$, respectivamente, enquanto para Umuarama foi de $-1,4^{\circ} \mathrm{C}$. Essa pequena diferença deve estar relacionada com as maiores altitudes das áreas de Paranavaí e Cianorte, em relação a Umuarama.

Quanto à precipitação, Cianorte e Umuarama apresentam médias anuais compreendidas entre $1.600 \mathrm{~mm}$ e $1.660 \mathrm{~mm}$; Paranavaí, entretanto, registra a média mais baixa, em torno de $1.490 \mathrm{~mm}$.

As três áreas de estudo apresentam uma estação seca bem-definida, que corresponde aos meses de inverno, enquanto que nos meses de verão as chuvas são mais abundantes.

\section{Vegetação}

A região noroeste do Paraná era totalmente recoberta por uma vegetação do tipo mata pluvial tropical, principalmente ao longo das drenagens; apresentava-se sempre densa e formada por árvores que chegavam a $40 \mathrm{~m}$ de altura, dentre as quais se destacavam: peróba-rosa, sapuva, guaritá, canafístula, e uma infinidade de espécies de menor porte (Bigarella \& Mazuchowski, 1985; Troppmair, 1994). A vegetação natural foi quase totalmente devastada durante o processo de ocupação, que se iniciou por volta da década de 40 , sendo substituída geraimente pelas plantações de café e pastagens naturais e, posteriormente, pelas pastagens artificiais. Após a erradicação dos cafezais, na década de 70 , essas áreas foram substituidas pela cana-de-açúcar. Na região deste estudo, a cobertura vegetal é composta predominantemente por pastagens, com algumas culturas anuais como o milho e o algodão. A destruição da mata pluvial tropical e o uso inadequado das áreas cultiváveis provocaram o empobrecimento do solo, através da erosão, reduzindo notavelmente as áreas agrícolas, muitas das quais foram substituídas por pastagens. Algumas áreas de reflorestamento, sobretudo com eucaliptos e grevilhas, aparecem na região. 
CIANORTE
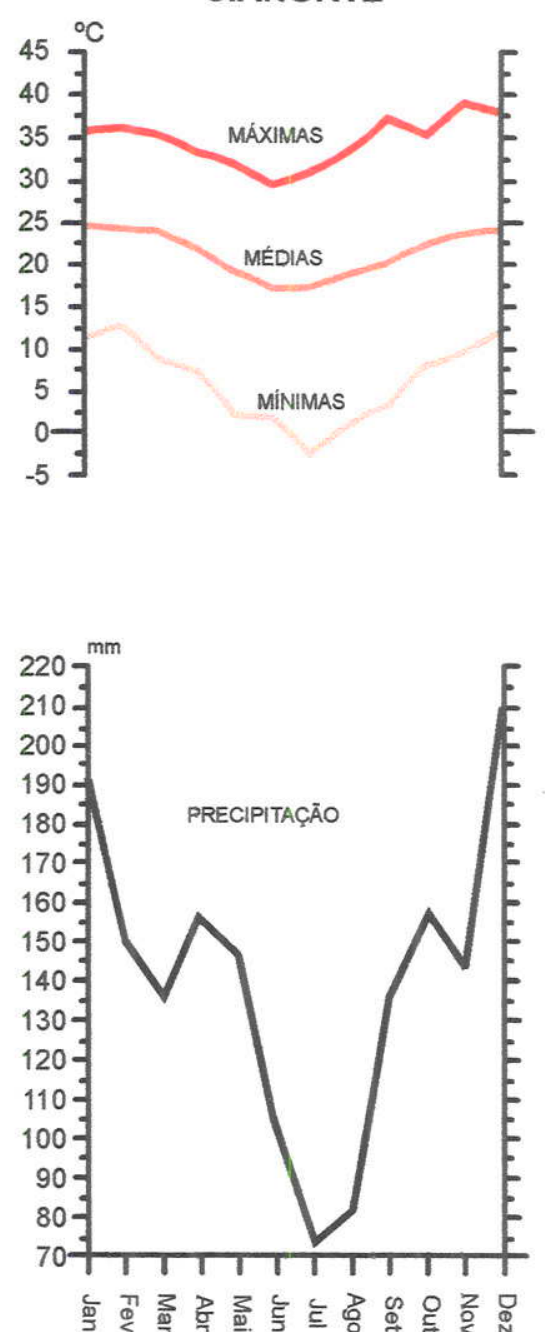

PARANAVAÍ
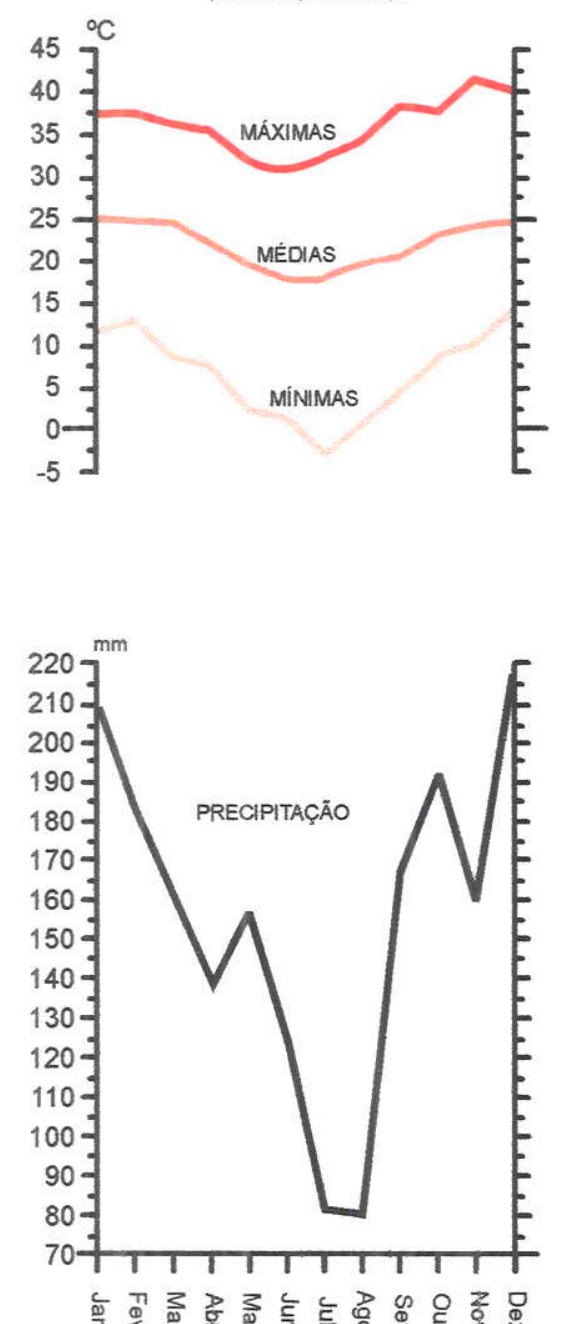

UMIARAMA
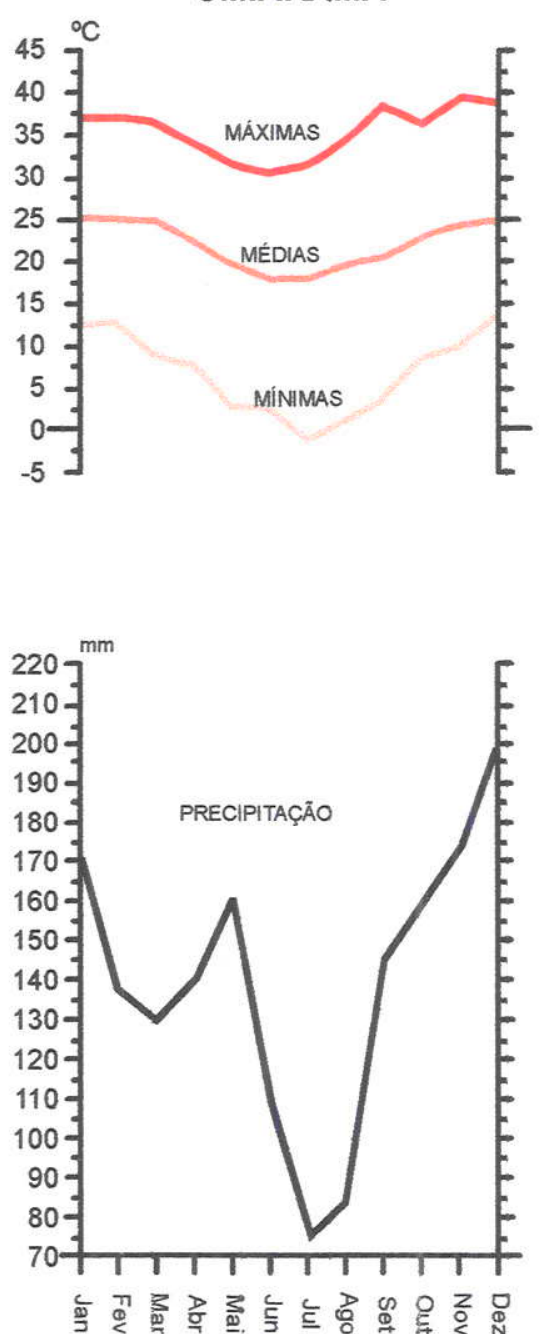

Fig. 1.2. Dados climáticos das áreas de estudo. Valores médios mensais de 1972 a 1993 segundo lapar (1994) 


\section{Localização das áreas de estudo}

Para a execução desta pesquisa, foram realizados estudos dos materiais das formações superficiais e do Arenito Caiuá, em três toposseqüências. As toposseqüências estudadas estão localizadas na região noroeste do Paraná, na área de ocorrência do Arenito Caiuá, situadas sobre os espigões, com altitudes médias em torno de $500 \mathrm{~m}$, os quais servem como divisores das bacias hidrográficas regionais. Esses topos correspondem a uma superfície denominada $\mathrm{Pd} 1$, que seria o testemunho de um processo de pedimentação de idade neogênica (Bigarella et al., 1965; Bigarella \& Mazuchowski, 1985). A escolha de tais áreas ocorreu em razão dessa compartimentação geomorfológica, pois acredita-se que sejam os locais que melhor preservam os materiais formados durante o último grande aplainamento. Para detalhar os estudos dos materiais que constituem as formações superficiais que recobrem o Arenito Caiuá foram selecionadas as toposseqüências nos municípios de Cianorte, Paranavaí e Umuarama (Fig.1.3).

A toposseqüência do sitio Três Leões está localizada ao sul de Cianorte, sobre o interflúvio principal entre as bacias hidrográficas do rio Ivaí, ao norte, e do rio Piquiri, ao sul, na zona de contato entre o Arenito Caiuá e as rochas vulcânicas da Formação Serra Geral. O acesso é feito a partir da cidade de Cianorte, seguindo-se pela Av. Paraíba até atingir a PR-323. Após, toma-se uma estrada vicinal no sentido sul, denominada Estrada Pão de Açúcar, que passa em frente da antena da COPEL, e percorrem-se aproximadamente $1.600 \mathrm{~m}$ para alcançar-se o sítio Três Leões.

A toposseqüência de Sumaré está situada a nordeste de Paranavaí, no setor dominado pelo Arenito Caiuá, no topo do interflúvio principal entre as bacias hidrográficas do rio Paranapanema, ao norte, e do rio Ivaí, ao sul. $O$ acesso pode ser feito a partir do bairro Sumaré, por uma estrada vicinal no sentido sudoeste, identificada na região como Estrada da Graciosa.

A nordeste de Umuarama, sobre o interflúvio principal, está situada a toposseqüência de Umuarama. Esse interflúvio também separa as bacias hidrográficas do rio Piquiri, ao sul, e do rio Ivaí, ao norte, porém mais próximo da calha do rio Paraná. A toposseqüência está localizada junto ao trevo de acesso à cidade de Maria Helena. 


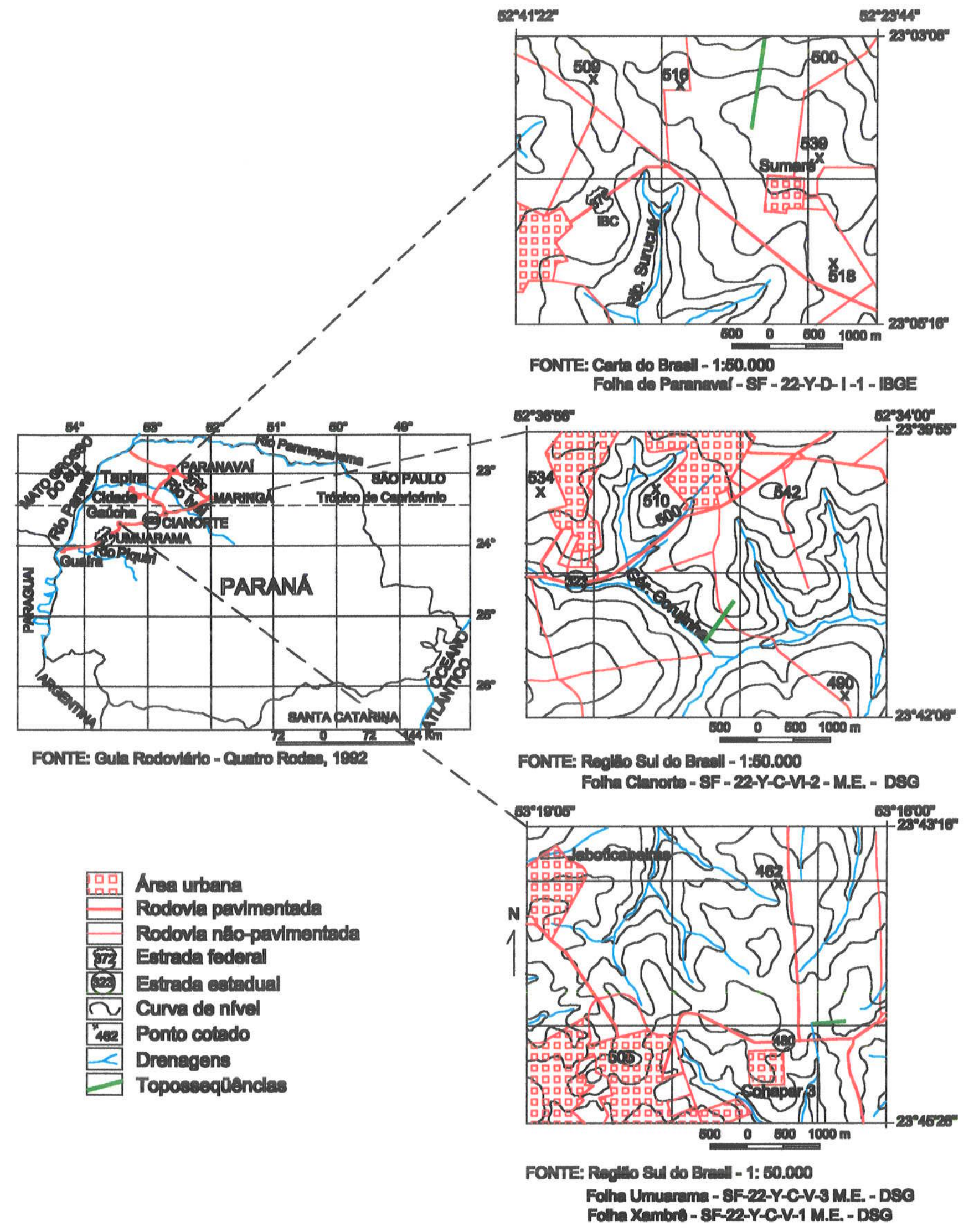

Fig.1.3. Mapas de locallzaça ๑ vlas de aceseo às áreas de estudo 


\section{CAPITULO II}

\section{TÉCNICAS ANALÍTICAS E ABORDAGEM METODOLÓGICA}

Praticamente todos os trabalhos relacionados com a origem das formações superficiais que ocorrem sobre o Arenito Caiuá foram elaborados a partir de amostras pontuais, muitas de origem duvidosa, coletadas sem critérios pré-definidos, durante excursões realizadas por diversos pesquisadores à região noroeste do Paraná. Outros dados, obtidos de estudos realizados no noroeste do estado de São Paulo com objetivo semelhante, foram extrapolados para toda a área de ocorrência do Arenito Caiuá, inclusive para o estado do Paraná. Somente nestes últimos anos têm surgido, no noroeste do estado, trabalhos sistemáticos, com base científica comprovada, que realmente trouxeram significativa contribuição na tentativa de elucidar problemas relacionados a essas formações (Bigarella \& Mazuchowski,1985; Cunha et al., 1990; Fernandes, 1992; Nóbrega et al., 1992; Fernandes et al., 1994; Cunha,1996; Gasparetto et al., 1993; Muratóri, 1997; Silveira, 1998; Cunha \& Nóbrega, 1998; Martins et al., 1998). Todos os trabalhos, entretanto, dão ênfase aos fenômenos erosivos, que são extremamente graves na região em decorrência da natureza arenosa dos materiais que constituem as formações superficiais. Com o mesmo propósito, mas visando estabelecer a possivel relação entre essas formações e o Arenito Caiuá, foi desenvolvida esta pesquisa.

Embora este trabalho não trate especificamente da análise estrutural da cobertura pedológica, foram utilizadas algumas etapas dessa metodologia (como o estudo em toposseqüências) para definir parâmetros quanto à proveniência dessa cobertura. $O$ estudo através de toposseqüencias permite, de forma clara, observar se existem descontinuidades, truncamento de camadas ou mesmo outras feições características, ao longo das vertentes, que permitam relacionar a cobertura superficial com o Arenito Caiuá sotoposto.

Portanto, para a elaboração deste trabalho, foram utilizadas diferentes escalas de abordagem: a) escala regional, enfatizando-se a compartimentação geomorfológica; b) escala da vertente, através do estudo de toposseqüencias; c) escala do perfil, com a descrição morfológica dos volumes; d) escala microscópica, para a caracterização geral dos constituintes dos volumes; e) escala ultramicroscópica (MEV), para a identificação de 
agregados naturais elementares e da morfologia externa dos gräos do esqueleto.

Para alcançar os objetivos propostos nesta pesquisa, foram desenvolvidas as seguintes etapas, descritas a seguir:

\section{- Estudo das toposseqüências}

Três toposseqüências foram selecionadas, em razão da compartimentação do relevo e também por representarem os tipos de vertentes mais comuns existentes na área de pesquisa. As toposseqüências foram estudadas com o emprego de sondagens a trado e abertura de trincheiras. Nas áreas selecionadas realizou-se uma descrição detalhada das características macromorfológicas dos solos. Foi dada atenção especial aos aspectos pedológicos e litológicos, como passagem de um volume a outro, variações texturais, de cor, presença de água livre, etc. Para complementar este estudo, outros aspectos foram observados, como: granulometria, parâmetros estatísticos granulométricos de Folk \& Ward (1957), minerais leves e pesados e a morfoscopia dos grãos detriticos de quartzo.

O estudo das formaçöes superficiais ao longo de vertentes foi iniciado por Bocquier (1972) e ampliado por Boulet et al. (1982a, b e c) e Boulet (1988). O estudo em toposseqüências, já consagrado na pedologia, consiste na análise dos solos em trincheiras, ao longo da vertente, em três pontos diferentes: topo, meia-encosta e sopé. Além desses pontos, de acordo com a metodologia adotada, são intercalados vários outros, cujo número e proximidade dependem das variações laterais notadas. O objetivo é relacionar lateralmente as observações feitas nos poços, reduzindo-se ao mínimo a incerteza introduzida pela interpolação de uma trincheira a outra. A operação termina quando é possivel desenhar sob um corte topográfico a distribuição dos diferentes volumes observados. Concluída a toposseqüência, tem-se, portanto, uma visão bidimensional das formações superficiais ao longo de uma vertente.

O estudo de detalhe ao longo de uma vertente permite que se verifique de modo preciso sua gênese e sua dinâmica, pois os materiais estão em equilíbrio determinado pelas condições pedobioclimáticas. Esse pode ser considerado um equilíbrio dinâmico, porque há uma formação e uma transformação que se sucedem continuamente no tempo (Boulet, 1974 e 1992). Ainda segundo o autor, se as condições pedobioclimáticas foram alteradas por mudança de clima ou modificação do lençol freático, ocorre na cobertura pedológica uma readaptação, buscando recuperar o equilíbrio nas novas condições. Além 
disso, essas análises permitem verificar se existem redistribuições internas de materiais (granulométricas e mineralógicas) ao longo da seqüência, e o papel que essas redistribuições desempenham na evolução do relevo.

\section{- Coleta de amostras}

Para a compreensão e quantificação dos processos pedogenéticos, foram desenvolvidas metodologias que enfocam a variabilidade espacial do solo (Boulet et al., $1982 a, b$ e c). Nesse contexto, as toposseqüências têm sido utilizadas com resultados bastante satisiatórios (Castro, 1989; Salomão, 1994; Santos, 1995; Cunha, 1996), permitindo que sejam realizadas amostragens sistemáticas ao longo de uma encosta. Assim, coletaram-se materiais de todos os horizontes, encontrados nas diferentes toposseqüências estudadas no noroeste paranaense.

As amostras para este trabalho foram coletadas em perfis, através da abertura de trincheiras previamente localizadas com as tradagens e obedecendo às mudanças de feições, como cor, textura e consistência do solo.

Todos os volumes foram amostrados, inclusive as transições entre os horizontes, sendo coletados dois tipos de amostras: uma amostra foi retirada com auxílio de uma caixa de cartolina previamente confeccionada, medindo $6 \times 10 \times 5 \mathrm{~cm}, \mathrm{com}$ a finalidade de manter a amostra de solo indeformada, tendo-se o cuidado de sempre anotar nas caixas o topo, a base, a profundidade e o volume que estava sendo amostrado. Essas amostras foram impregnadas, e foram confeccionadas lâminas delgadas para o estudo micromorfológico das formações superficiais. A outra amostra, deformada e acondicionada em sacos plásticos, foi utilizada para análises granulométricas, determinação dos minerais pesados, difração de raios-x e espectroscopia de absorção de infravermelho.

\section{- Técnicas analiticas}

No laboratório, as amostras coletadas foram submetidas a análises físicas e estudos mineralógicos.

- Análises físicas: todas as amostras deformadas foram submetidas a determinações granulométricas por via úmida (pipetagem) para a argila e o silte e peneiramento para as frações grosseiras, utilizando-se jogos de peneiras com intervalo de $1 / 2 \varnothing$. Para todos os intervalos das frações granulométricas foi calculado o percentual em peso. Com os 
resultados dessas análises foram determinados os parâmetros estatísticos granulométricos que, associados a dados granulométricos, são importantes na definição dos processos de alteração, transporte e deposição, bem como de proveniência de materiais (Folk \& Ward, 1957; Pettijohn, 1975; Duane, 1964; Ponçano, 1986; Giannini, 1987).

- Minerais pesados: as frações compreendidas entre $3.0 \varnothing$ e $4.0 \varnothing(0,125 \mathrm{~mm}$ a $0,053 \mathrm{~mm})$, de todas as amostras, foram separadas e utilizadas para a determinação dos minerais pesados. Para a separação dos minerais pesados, utilizou-se o método descrito por Carver (1971), através do qual é realizada a separação por gravimetria utilizando-se o bromofórmio como liquido denso e funil de separação. Optou-se pelo bromofórmio devido ao fato de o valor de sua densidade ser considerado como o limite clássico de separação entre os constituintes leves e pesados. Após a separação, a fração pesada é lavada com álcool etílico e seca em estufa. Posteriormente, confeccionaram-se as lâminas, com a montagem de grãos sobre bálsamo-do-canadá.

Determinar a proporção dos minerais pesados caracteriza-se como uma das principais etapas do trabalho, pois o resultado da pesquisa depende principalmente dessa fase. Assim, optou-se pelo processo de contagem dos grãos, com a finalidade de estimar a porcentagem de cada constituinte na amostra. O método utilizado foi o de linhas transversais, bastante comum quando se trata de lâminas montadas (Galehouse, 1971; Tomazelli, 1977). O processo consiste na contagem dos grãos em linhas eqüidistamente espaçadas na lâmina. A vantagem desse método é que o mineral só é contado quando atinge o centro de retículo do microscópio, portanto na posição ideal de identificação, além de ser menos cansativo.

Para a determinação dos minerais pesados opacos, procede-se da seguinte maneira: inicialmente, contam-se 100 grãos; assim, são determinados os opacos que ocorrem em cada lâmina. Feito isso, os grãos de opacos são ignorados e contam-se 100 grãos dos não-opacos. Desse modo, diminui-se a possibilidade de erro, aumentando-se consideralvelmente a precisão da análise. No caso da amostra conter $90 \%$ de opacos, e 100 grãos de não-opacos serem contados, isso equivale, em termos de precisão, a uma contagem de aproximadamente 1.000 gãos de cada amostra (Griffiths, 1967).

O resultado dessa contagem é a freqüência com que o mineral atinge o retículo. Essa freqüência pode ser considerada como a porcentagem, uma vez que os grãos montados na lâmina apresentam praticamente as mesmas dimensões. 
- Análises micromorfológicas: em decorrência da natureza friável dos materiais, as amostras indeformadas coletadas de solos e da rocha alterada foram submetidas a impregnação segundo a técnica preconizada por Verbeke (1969), utilizando-se resina acrílica polylite ( $T-208)$ pré-acelerada, como solvente monômero de estireno, e como catalisador peróxido de metil-etil-acetona (peroxol). A impregnação ocorre sob vácuo, com as amostras previamente secas em estufas $\left(40^{\circ} \mathrm{C}\right)$ durante 72 horas. Para as análises micromorfológicas, foram utilizados dois niveis de observação: microscopia óptica (lâminas delgadas) e microscopia eletrônica de varredura (fragmentos). Os resultados da micromorfologia auxiliam na identificação dos processos (alteração, erosivos, deposicionais ou de transformação) que atuaram sobre as formações superficiais.

- Microscopia óptica: os procedimentos e a terminologia para as descrições das lâminas foram baseados em Brewer (1964); Stoops \& Jongerius (1975); Curi et al. (1985).

A partir das análises das lâminas, foi possivel identificar os minerais e delimitar sítios para caracterizar as organizações encontradas nos materiais (esqueleto, plasma, poros, orientações plámicas e do esqueleto, distribuição, forma e orientações dos constituintes do fundo matricial) que formam os materiais das áreas de estudo. As observações microscópicas foram efetuadas sob luz natural e luz polarizada com aumentos que variavam de $25 x$ a $100 x$. Os menores aumentos servem para identificar e caracterizar os materiais, as organizações, e selecionar sítios representativos para análise de detaihe. Os sítios foram delimitados com lápis sobre o lado da lâmina sem a lamínula (o uso do lápis é preferível porque os traços podem ser facilmente apagados com borracha comum). Os aumentos maiores são mais adequados para se observar e identificar aspectos relacionados com as orientações do plasma como estrutura, entre outros.

- Microcopia eletrônica de varredura (MEV): alguns fragmentos de amostras, previamente selecionados, da cobertura superficial, nódulos ferruginosos e arenito alterado, foram submetidos à microscopia eletrônica de varredura. O uso da microscopia eletrônica de varredura, nesta linha de pesquisa, reveste-se de importância, uma vez que complementa as obervações efetuadas com a microscopia óptica convencional. Sua importância é de fundamental interesse, porque permite que se obtenham imagens tridimensionais da forma e arranjo interno dos microconstituintes, além de auxiliar na caracterização mais precisa das organizações plásmicas, arranjo dos poros e dos grãos detriticos do esqueleto, que constituem as formações superficiais. 
As análises foram efetuadas sobre fratura fresca de pequenos fragmentos indeformados mais ou menos planos e sobre os grãos detríticos individuais. Devido à baixa condutividade elétrica, todas as amostras foram metalizadas com ouro, carbono ou uma combinação de ambos, sob vácuo. Porém o recobrimento com carbono é preferivel, porquanto adere fortemente à superfície das amostras, favorecendo a condutividade elétrica e reforçando as partes mais frágeis, que podem ser deslocadas durante a incidência do feixe eletrônico oriundo do microscópio (Smart \& Tovey, 1982). Para cada amostra analisada foram preparados três fragmentos.

As observações foram efetuadas com diferentes aumentos, visando, inicialmente, identificar as organizações do fundo matricial, isto é, as organizações plásmicas, formas dos agregados, tipo de porosidade e distribuição do esqueleto. Os aumentos maiores (1.000x a 3.500x) são usados para detalhar certas zonas do plasma no interior dos poros, bem como para detectar produtos neoformados ou revelar detalhes complexos existentes na superficie dos grãos de quartzo que não são identificados com o miscrópio petrográfico comum.

Neste trabalho foi utilizado o microscópio eletrônico de varredura da marca GEOL JSMT-330A, equipado com uma microssonda NORON série Micro Z (EDS-espectroscopia de dispersão de raios- $x$ ), pertencente ao IAG-USP.

- Difratometria de raios-x: algumas amostras previamente selecionadas dos volumes das toposseqüências do sítio Três Leões e de Sumaré, coletadas no topo, meia-encosta e sopé da vertente, foram sumetidas à difratometria de raios- $x$. Essas análises foram realizadas em amostra total sobre fração granulométrica menor do que 2 micra, no seu estado natural e posteriormente com tratamentos especificos.

Inicialmente, pulverizaram-se as amostras e procedeu-se à análise do pó nãoorientado. O equipamento utilizado foi um difratômetro da marca Siemiens com tubo de cobalto, $35 \mathrm{kV}, 20 \mathrm{~mA}$, velocidade $2^{\circ} /$ minuto e $2^{\circ}$ a $90^{\circ}$. No intevalo $2^{\circ}$ a $32^{\circ}$ foram obtidos difratogramas com amostras natural, glicolada e calcinada a $500^{\circ} \mathrm{C}$, para a identificação dos argilominerais.

Para a identificação dos argilominerais, o pó das amostras pulverizadas foi misturado com água destilada, colocada num aparelho de ultrassom durante 15 minutos. Após, as amostras permaneceram em repouso por 2 horas e 30 minutos. Devido à 
pequena quantidade de material em solução, utilizou-se o processo de centrifugação, com a finalidade de concentrar a solução, e pipetaram-se $3 \mathrm{ml}$ de amostra sobre lâmina de vidro.

A identificação das argilas reveste-se de importância, uma vez que elas refletem, em geral, as condições ambientais de quando foram formadas e, também, as variações mineralógicas e o grau de cristalinidade, parâmetros esses que podem ser utilizados na definição de proveniência dos materiais da cobertura pedológica.

- Espectroscopia de absorção de infravermelho: o uso da técnica de infravermelho no campo de análise de minerais dos solos foi amplamente difundido por vários pesquisadores, entre os quais Fripiat (1960), Farmer \& Russel (1964), Chester \& Green (1968), Gadsden (1975), Farmer \& Palmieri (1975), Olphen \& Fripiat (1979), White \& Roth (1986), Russel \& Fraser (1994), Nóbrega (1995). A vantagem dessa técnica sobre as demais ocorre em razão de ser simples, rápida e econômica, fornecendo resultados precisos quanto à estrutura cristalina e na identificação de minerais com diferente composição química. Além disso, argilominerais como caulinita e gibbsita, cuja estrutura não apresenta substituições isomórficas significativas, são detectados e identificados com concentrações muito baixas, da ordem se $1 \%$ a $2 \%$, o que não acontece com as outras técnicas, as quais necessitam de um percentual maior (White \& Roth, 1986). Contudo, seu uso tem sido limitado, devido aos excelentes avanços obtidos com a difração de raios-x.

Existem várias técnicas de preparação de amostras para se determinar o espectro de absorção de infravermelho. É provável que a técnica mais comumente usada para a determinação dos constituintes do solo, e que também foi usada nesta pesquisa, seja a pastilha de $\mathrm{KBr}$. A utilização do brometo de potássio reveste-se de importância, porque ele não absorve luz infravermelha na região compreendida entre $2,5 \mu$ e $15 \mu$, obtendo-se, assim, um espectro completo da amostra (White \& Roth, 1986).

Para preparar uma pastilha de $1 \mathrm{~mm}$ a $2 \mathrm{~mm}$ de espessura e com $10 \mathrm{~mm}$ a $13 \mathrm{~mm}$ de diâmetro, misturam-se de $0,3 \mathrm{mg}$ a $0,5 \mathrm{mg}$ de amostra com $300 \mathrm{mg}$ de $\mathrm{KBr}$, bem seco, em gral de ágata. A mistura deve ser mantida no mínimo por 12 horas numa estufa a $45^{\circ} \mathrm{C}$. Posteriormente, são preparadas as pastilhas em prensa hidraúlica $(4.000 \mathrm{~kg}$ a $11.000 \mathrm{Kg})$, sob vácuo. A pastilha obtida geraimente é transparente, e deve permanecer por uma noite em estufa a $60^{\circ} \mathrm{C}$, antes de ser submetida à análise. O espectro é determinado colocandose a pastilha que contém a amostra em um suporte especial, ao lado de uma pastilha de $\mathrm{KBr}$ puro,como padrão de referência. 
Neste trabalho foi utilizado um espectrômetro de absorção de infravermelho da marca BOMEM-MB-100, do Departamento de Química da Universidade Estadual de Maringá. 


\section{CAPÍTULO III}

\section{CARACTERIZAÇÃO DAS TOPOSSEQÜÊNCIAS}

Serão descritas neste capitulo as principais caracteristicas apresentadas pelas toposseqüências estudadas, abordando-se a organização dos volumes pedológicos, suas características morfológicas e micromorfológicas (microscopia óptica e microscopia eletrônica de varredura) no perfil e ao longo da vertente, a distribuição das frações granulométricas, os parâmetros estatísticos granulométricos de Folk \& Ward (1957), a relação silte/argila e a análise morfoscópica dos grãos do esqueleto, bem como a caracterização mineralógica do Arenito Caiuá e das formações superficiais.

\section{Caracterização morfológica e micromorfológica}

Para descrever a micromorfologia dos materiais que constituem as formações superficiais, foi dada ênfase às seguintes características: a) ao fundo matricial, como o definido por Brewer (1964), o qual é composto pelos grãos detríticos do esqueleto, maiores do que $2 \mu$, pelo plasma constituído de partículas de tamanho inferior a $2 \mu$ e pelos vazios interagregados; b) as feições pedológicas, que são formadas pelas separações plásmicas originadas pelas reorganizações do plasma ao redor do esqueleto, dos poros e pelos cutãs propriamente ditos formados por migraçöes e acumulações do plasma junto aos vazios; c) as estruturas de base referem-se à distribuição relativa entre o plasma, o esqueleto e os poros, e são identificadas sob luz natural. Seguem as descrições e a classificação proposta por Stoops \& Jongerius (1975); d) as estruturas plásmicas também foram definidas por Brewer (1964) e são formadas a partir das reorganizações do plasma anisotrópico, sob nicóis cruzados, no qual podem se identificar domínios com extinção em manchas ou sob forma de separações plásmicas.

Os procedimentos e a terminologia para as descrições das lâminas foram baseados em Brewer (1964) e Stoops \& Jongerius (1975). Quanto à nomenclatura em português, foi utilizada a tradução proposta por Curi et al. (1985). 


\subsection{Toposseqüência do sítio Três Leões}

A toposseqüência do sítio Três Leões está situada numa vertente da margem esquerda do córrego Corujinha, afluente do córrego Catingueiro. A área apresenta topografia ondulada, com o topo da vertente convexo, pouco marcado, porém à medida que se desce a declividade torna-se mais acentuada, principalmente no setor inferior, onde se destaca um segmento com perfil convexo bem marcado. A vertente termina no córrego Corujinha, que se encontra assoreado, e cujos sedimentos recobrem, na maior parte das vezes, os afloramentos do Arenito Caiuá do leito (Fig. 3.1).

Para facilitar a compreensão a toposseqüência foi subdividida em segmentos a partir do topo até o sopé (alta vertente, média alta vertente, terço inferior). As descrições macro e micromorfológicas estão em seqüência e resumidas no Anexo 2, e visam a um melhor entendimento de como se desenvolvem a distribuição e a passagem de um volume a outro, além de permitir o acompanhamento evolutivo dos materiais pedológicos na vertente.

No setor de topo e alta vertente, a cobertura pedológica é composta por dois volumes: um superficial, de textura arenosa e areno-franca, pouco espesso, e outro em subsuperficie, de textura franco-argilo-arenosa, espesso.

$O$ volume superficial, com espessura aproximada de $60 \mathrm{~cm}$, apresenta cores que variam do vermelho ao vermelho-escuro (2,5YR $4 / 8$ a 3/6), textura franco-arenosa, estrutura maciça porosa, muito friável, não-plástica, não-pegajosa, porosidade formada predominantemente por empilhamento simples de grãos, além de alguns poros tubulares

e canais milimétricos originados por atividade biológica (raízes e insetos). É comum a presença de pequenos fragmentos de carvão e de bolsões centimétricos preenchidos total ou parcialmente por areia lavada de cor mais clara. A transição para o volume abaixo é clara a ondulada.

O volume superficial apresenta um fundo matricial constituído por, aproximadamente, $5 \%$ a $15 \%$ de plasma, $60 \%$ de esqueleto e $25 \%$ de porosidade. $O$ plasma, sob luz natural, apresenta cores que variam do vermelho ao bruno-escuro; sob luz polarizada, é isótico (opacidade devido à matéria orgânica e ao ferro), com raros domínios 


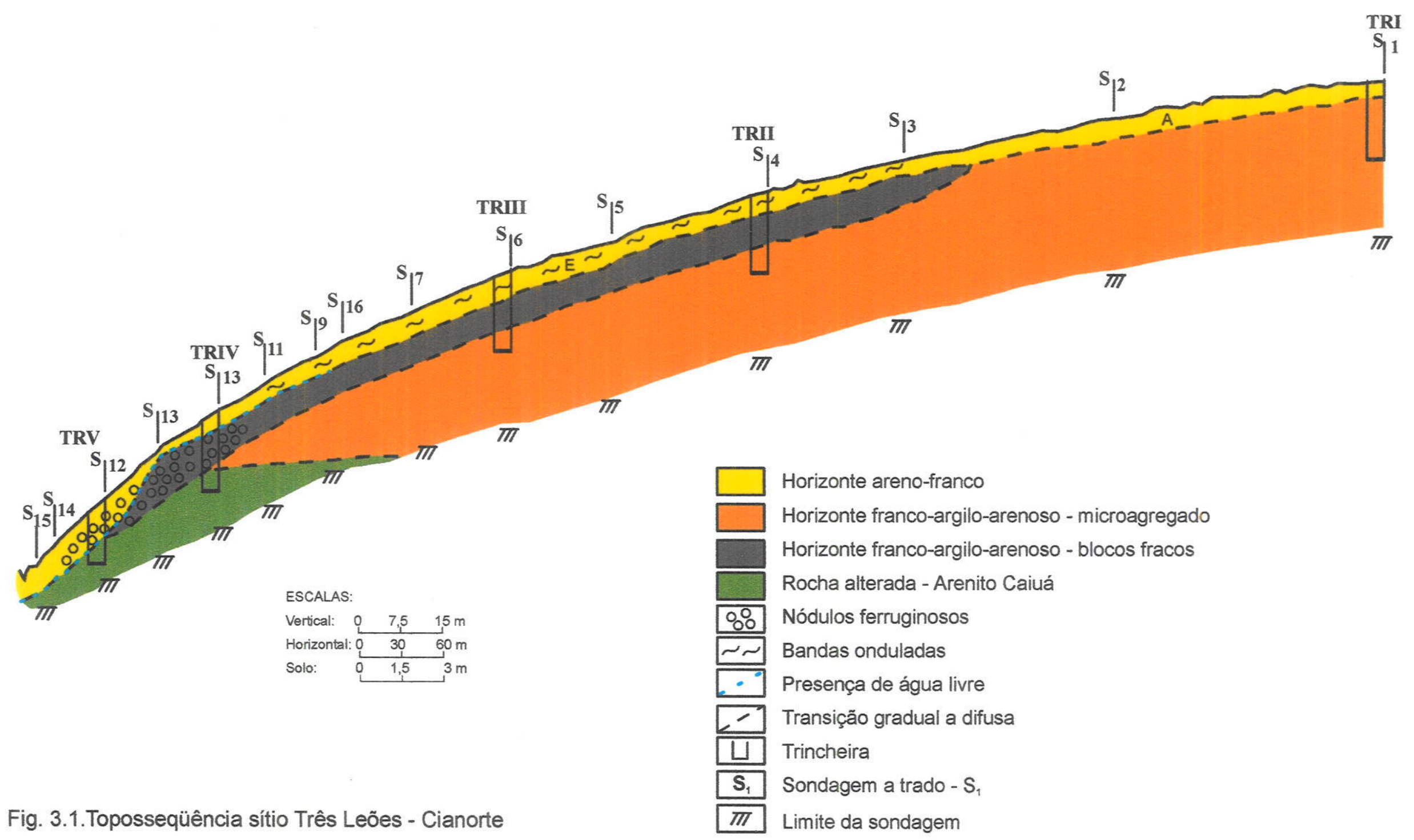


argilassépicos. A distribuição relativa entre o plasma e o esqueleto é predominantemente quito-gefúrica, como se observa na PRANCHA I - Fotomicrografia 1. Em alguns setores, entretanto, se apresenta como porfírica.

O esqueleto é formado predominantemente por grãos de quartzo nas frações areia fina a muito fina. Em determinados setores, o esqueleto apresenta-se orientado e mais adensado. A porosidade é formada por empilhamento simples de grãos, e fortemente comunicante. A origem dessa porosidade é atribuída a processos pedogenéticos.

O volume subjacente é espesso $(+350 \mathrm{~cm})$, de textura franco-argilo-arenosa $e$ estrutura microagregada, correspondendo a um horizonte $B$ latossólico. Nesse volume o plasma aumenta para $35 \%$ do total dos constituintes. Sob luz natural, apresenta cores que variam do vermelho ao vermelho-claro, com tons alaranjados, e sob luz polarizada é argilassépico. A estrutura de base do plasma com o esqueleto é quito-enáulica (PRANCHA I - Fotomicrografia 2).

Nesse volume o esqueleto diminui um pouco, mantendo suas características em termos de tamanho, forma e distribuição. A porosidade, embora um pouco menor, é originada pelo empilhamento complexo de grãos e de agregados, permanecendo fortemente comunicante, ocorrendo também algumas cavidades.

A partir da média alta vertente, aparece um terceiro volume, situado entre o volume superficial e o $\mathrm{B}$ latossólico. Isso ocorre porque, à medida que se desce na vertente, O $\mathrm{B}$ latossólico vai, de forma gradativa, sendo enriquecido lateralmente em argila, fazendo que a partir desse ponto surja um volume franco-argilo-arenoso, com característica de B textural, que se prolonga até o início do terço inferior, quando grada por interpenetração para o volume arenoso superficial, que nesse setor da vertente torna-se mais espesso.

Nesse segmento, a estrutura de base do volume superficial tende a variar gradativamente, passando de quito-gefúrica a parcialmente quitônica. Em alguns setores apresenta-se predominantemente mônica (PRANCHA I - Fotomicrografia 3). Aparecem ainda inúmeras bandas, de $2 \mathrm{~cm}$ a $5 \mathrm{~cm}$ de espessura, mais argilosas, com teores de plasma que podem atingir $25 \%$, gerando uma estrutura de base porfírica. Nessas bandas o plasma é isótico, apresentando-se, contudo, em alguns setores, como granossépico e porossépico. A porosidade passa a ser moderadamente comunicante, formada por fissuras e cavidades. 
No novo volume subsuperficial franco-argilo-arenoso (Bt), o plasma aumenta bastante (até $60 \%$ ) e é de cor vermelho-alaranjada sob luz natural. No contato com os grãos do esqueleto e nas bordas dos poros, sob luz polarizada, o plasma apresenta orientação moderada a forte contínua, por vezes interrompidas por fissuras, dando origem a estruturas plásmicas preferencialmente sépicas do tipo granossépicas e porossépicas. Cutãs de iluviação com orientação forte contínua estão presentes, geralmente associados às paredes de poros. A porosidade passa a ser formada por cavidades irregulares, tornando-se moderada a fracamente comunicante. O esqueleto, apesar de manter as características descritas anteriormente, sofre uma redução acentuada (PRANCHA 1 Fotomicrografias 4 e 5).

A transição do volume franco-argilo-arenoso (Bt) para o $B$ latossólico sotoposto é marcada pela diminuição de plasma. A estrutura porfírica começa a desmantelar-se e dar origem a domínios em que varia de gefúrica a enáulica. Além da redução de plasma, há um aumento signficativo da porosidade e moderado do esqueleto, semelhante às características micromorfológicas do volume franco-argiloso-arenoso (Bw), de montante. Os cutãs tornam-se raros e a estrutura plásmica passa a ser predominantemente enáulica (PRANCHA I - Fotomicrografia 6).

No terço inferior da vertente, o volume franco-argilo-arenoso, microagregado (Bw), desaparece em forma de cunha, e o Bt está justaposto diretamente sobre um volume de rocha alterada (Arenito Caiuá). Mais a jusante o volume Bt também desaparece em forma de cunha, e nesse ponto (TR-V) o volume superficial é mais espesso, tendo, logo abaixo, a rocha alterada.

Nesse setor, entre as sondagens $S_{11}$ e $S_{14}$ surge uma zona nodular (glébulas) em forma de lente, inicialmente dentro do $\mathrm{Bt}\left(\mathrm{S}_{10}\right.$ a $\left.\mathrm{S}_{13}\right)$, e que se prolonga, quando este acaba, no interior do volume superficial até o sopé da toposseqüência.

No volume superficial, os nódulos estão imersos numa matriz arenosa lavada, com estrutura de base predominantemente mônica. A porosidade é formada por empilhamento simples de grãos e é fortemente comunicante (PRANCHA II - Fotomicrografias 1 e 2).

Através da análise microscópica, verifica-se que os limites dos nódulos variam de nítidos, quando inalterados, a difusos, quando estão sendo destruídos. O plasma do centro 
dos nódulos, de cor bruno-escura, pode alcançar $75 \%$ do total dos constituintes. Em geral, o plasma é isótico e apresenta estrutura de base essencialmente porfírica e alguns setores com estrutura plásmica do tipo granossépica e porossépica. O plasma alaranjado ocorre, de forma descontínua, ao redor dos nódulos, dando origem a concentrações e/ou separações plásmicas com limites progressivos para o interior dos mesmos e abruptos com a matriz. Essas variaçōes de cores, normalmente associadas às bordas dos nódulos e à porosidade, podem indicar uma remobilização do plasma ferruginoso (PRANCHA II Fotomicrografias 3 e 4).

O esqueleto do interior dos nódulos apresenta as mesmas características dos demais volumes, com relação ao tamanho e forma; entretanto, em alguns nódulos, a distribuição dos grãos do esqueleto lembra a estratificação do arenito, isto é, com microcamadas paralelas constituidas de grãos de tamanhos diferentes (PRANCHA II Fotomicrografia 5). A porosidade intranódulos, em geral, é não-comunicante, porém pode variar para fracamente comunicante nas camadas formadas por esqueleto grosseiro e em setores cavitários, ou então quando se instalam redes irregulares de microfissuras.

A matriz que envolve os nódulos, dentro do $\mathrm{Bt}$, apresenta variação de estrutura de base: no topo do volume é quito-gefúrica, por vezes enáulica, com porosidade fortemente comunicante; na base é porfírica, com porosidade fracamente comunicante.

A presença de nódulos ferruginosos é importante porque eles representam restos reliquiares do Arenito Caiuá, testemunhando que em tempos passados esse arenito estava presente, em posição mais elevada no perfil.

A presença do Arenito Caiuá alterado somente foi constatada no final da vertente, a partir da sondagem $S_{9}$, a $270 \mathrm{~cm}$ de profundidade. Nesse setor, o arenito alterado apresenta cores que variam de rosa a amarelo-avermelhada (5YR 8/3 a 6/8), até vermelhoescuro-acinzentada a rosa (10R $3 / 4$ a $5 Y R$ 7/4). Essas alternâncias de cores estão associadas à estratificação da rocha e, também, a inúmeras fraturas preenchidas por material mais argiloso, com sinais de hidromorfia, de cores claras, na zona de oscilação do lençol freático.

No Arenito Caiuá, a matriz apresenta, sob luz natural, cor vermelha, mas pode apresentar tons violáceos marrom e vermelho-alaranjado. É constituída de argila e óxido 
de ferro. No geral o material da matriz é isótico, e junto às fissuras ocorrem concentrações de plasma iluvial, dando origem a cutãs, com extinção forte contínua. A porosidade é formada por fissuras, canais, cavidades e, em áreas mais lavadas, com material grosseiro, aparece uma porosidade formada pelo empilhamento complexo de grãos. Os canais e/ou fraturas de formas irregulares eventualmente aparecem preenchidos com materiais de granulometria mais fina e plasma mais claro, ambos fortemente comunicantes (PRANCHA II - Fotomicrografia 6).

A seguir serão mostradas várias PRANCHAS com uma série de fotomicrografias, obtidas no microscópio eletrônico de varredura (MEV), de fragmentos indeformados do solo e do Arenito Caiuá, permitindo que sejam observadas com mais detalhes as relações entre os constituintes (plasma, esqueleto e os poros), bem como a forma e as diferentes feições desenvolvidas pela alteração química sobre os grãos de quartzo.

Na PRANCHA III - Fotomicrografia 1, no volume A ocorrente no topo da vertente, observa-se a distribuição homogênea do plasma bruno-escuro, individualizado na forma de pequenos agregados crenulados e na forma de revestimento, formando uma fina película de cor vermelha que pode recobrir total ou parcialmente os grãos do esqueleto.

$O$ esqueleto mostra-se moderadamente selecionado, constituido praticamente pelas frações areia fina a areia muito fina. A porosidade textural é abundante, embora em determinados setores haja o desenvolvimento de cavidades interligadas que favorecem uma boa percolação da água nesse setor da vertente.

No volume $B$ latossólico sotoposto, o plasma vermeiho a vemelho-escuro aumenta, ocorrendo de duas formas: ora formando pequenas concentrações, que se distribuem de forma aleatória pela amostra, recobrindo os grãos do esqueleto, ora formando microagregados, sendo possivel sob aumentos maiores $(350 \mathrm{x})$, ver pequenas concentrações no interior dos poros (PRANCHA III - Fotomicrografias 2 e 3 ).

$O$ esqueleto ocorre em menor quantidade do que no volume superior, porém preserva as mesmas características. No entanto, vê-se que alguns grãos do esqueleto estão lavados, sem plasma, enquanto outros apresentam fina película de recobrimento. A porosidade sofre pequena redução, mas continua fortemente comunicante, desenvolvendo, em razão da trama gerada pelo esqueleto, espaços vazios totalmente livres para circulação 
da água (PRANCHA III - Fotomicrografia 4).

Sob aumentos maiores $(1.500 x)$, a superfície dos grãos de quartzo torna-se crenulada e irregular devido aos ataques químicos, que tendem a solubilizar as camadas mais externas dos grãos, desenvolvendo uma série de pequenas figuras triangulares (PRANCHA III - Fotomicrografia 5). Com aumentos maiores (3.500x), é possível observar o quartzo bastante corroído, desenvolvendo formas definidas comumente como "dente de cão". Sobre essa superfície ocorre pequeno filamento, com aspecto de renda, composto predominantemente por sílica, caracterizando processos de reprecipitação de sílica (PRANCHA III - Fotomicrografia 6).

No segmento que compreende a média vertente, ocorre maior mobilidade da argila através dos interstícios, tanto na vertical como lateralmente, promovendo um aumento significativo do plasma de cor vermelho-alaranjada, caracterizando a estrutura de base porfírica fechada (PRANCHA IV - Fotomicrografia 1). Surge um grande número de cutãs de iluviação, associados com os poros e também com o esqueleto, em torno dos quais o plasma encontra-se orientado. Verifica-se a existência de pequenas fissuras originadas pelos processos de umectação e ressecamento (PRANCHA IV - Fotomicrografia 2).

Os grãos do esqueleto estão praticamente todos mergulhados no plasma, mas quando estão visíveis verificam-se, também, pequenas fissuras causadas pelo desprendimento do plasma do esqueleto. A porosidade textural desaparece, predominando aquela formada pelas fissuras, cavidades irregulares e alguns pedotúbolos, tornando-a fracamente comunicante.

No interior dos nódulos, que aparecem no final da vertente, o plasma bruno-escuro é abundante, apresentando uma composição ferruginosa que se aproxima da hematita (PRANCHA IV - Fotomicrografia 3). Seu aspecto assemelha-se a uma superfície botrioidal constituída de pequenos esferulitos ricos em óxidos ferro. Nas feições semelhantes a renda ou acordeom, predominam minerais com a composição da caulinita. Apesar de os materiais estarem associados, não apresentam a mesma composição química (hematita e caulinita), justificada por uma descontinuidade física entre os produtos neoformados (PRANCHA IV Fotomicrografia 4).

A maior parte dos grãos do esqueleto está rodeada pelo plasma, que desenvolve 
feições parecidas com aquelas do volume $\mathrm{Bt}$, isto é, o plasma parece estar se desprendendo dos grãos do esqueleto, dando origem a um sistema fissural responsável pela porosidade no interior do nódulo. Nas partes centrais dos nódulos, podem ser encontrados produtos neoformados bem-cristalizados, com a composição do feldspato potássico e da gibbsita (PRANCHA IV - Fotomicrografias 5 e 6 respectivamente). Essas formas bem-preservadas representam produtos reliquiares que ficam preservados no interior dos nódulos, confirmando a existência de condições climáticas diferentes das atuais no passado.

Na PRANCHA V observa-se o aspecto geral do arenito alterado. $O$ alteroplasma marrom-avermelhado apresenta características diferentes do plasma da cobertura superficial. No arenito, o alteroplasma ocorre como fina película, rica em ferro, que pode envolver total ou parcialmente os grãos. Quando essa pelicula se rompe, exibe no seu interior os grãos de quartzo, que, nesse caso, são límpidos e menos corroídos do que aqueles encontrados no solo (PRANCHA V - Fotomicrografia 1 e 2). São encontrados também, no arenito, restos de minerais primários, como o feldspato potássico e a mica muscovita. O feldspato está totalmente alterado, corroído, formando pequenas reentrâncias que às vezes estão preenchidas por minerais neoformados, com a composição da caulinita (PRANCHA V - Fotomicrografia 3). Associados à caulinita e com a mesma textura podem ocorrer produtos amorfos ou malcristalizados, não desenvolvendo picos característicos de cristalinidade quando analisados por EDS.

Exemplos de mica folhada foram encontrados perfeitamente preservados, exibindo a composição da muscovita, envoltos em uma massa com a composição da caulinita mais o ferro (PRANCHA V - Fotomicrografia 4). 


\section{PRANCHA I}

\section{TOPOSSEQÜENCIA SITIO TRESS LEÖES}

Fotomicrografia 1: volume francoarenoso com plasma de cor brunoescura desenvolvendo estrutura de base quito-gefúrica. Onde o plasma está mais concentrado o esqueleto está mais adensado, reduzindo a porosidade. A origem desse adensamento é atribuida ao manejo agrícola.

Microscópio óptico, luz natural

Fotomicrografia 3: volume areno-franco (E) superficial com grãos do esqueleto lavado desenvolvendo a estrutura de base mónica. Em alguns setores da lâmina ocorrem concentrações de plasma bruno-escuro que podem unir através de pontes os gräos do esqueleto, originando a estrutura de base gefúrica. Os poros são formados por empilhamento simples de gräos, sendo fortemente comunicantes.

Microscópio óptico, luz natural

Fotomicrografia 5: volume franco-argiloarenoso (Bt) com plasma brunoavermelhado que, devido às reorganizaçöes e concentrações, apresentam separações plásmicas associadas tanto aos poros como ao esqueleto (cutãs de iluviação).

Microscópio óptico, luz polarizada
Fotomicrografia 2: volume franco-argiloarenoso (Bw) profundo, o plasma aumenta apresentando estrutura de base enáulica.

Microscópio óptico, luz natural

Fotomicrografia 4: volume franco-argiloarenoso (Bt) com estrutura de base porfirica dominante. O plasma brunoavermelhado apresenta microfissuras devido às expansōes e concentrações. A porosidade sofre uma redução acentuada se comparada com o volume superior (E).

Microscópio óptico, luz natural

Fotomicrografia 6: detalhe do volume franco-argilo-arenoso (BW), sob o Bt, com microagregação bem-desenvolvida. Microscópio óptico, luz natural 

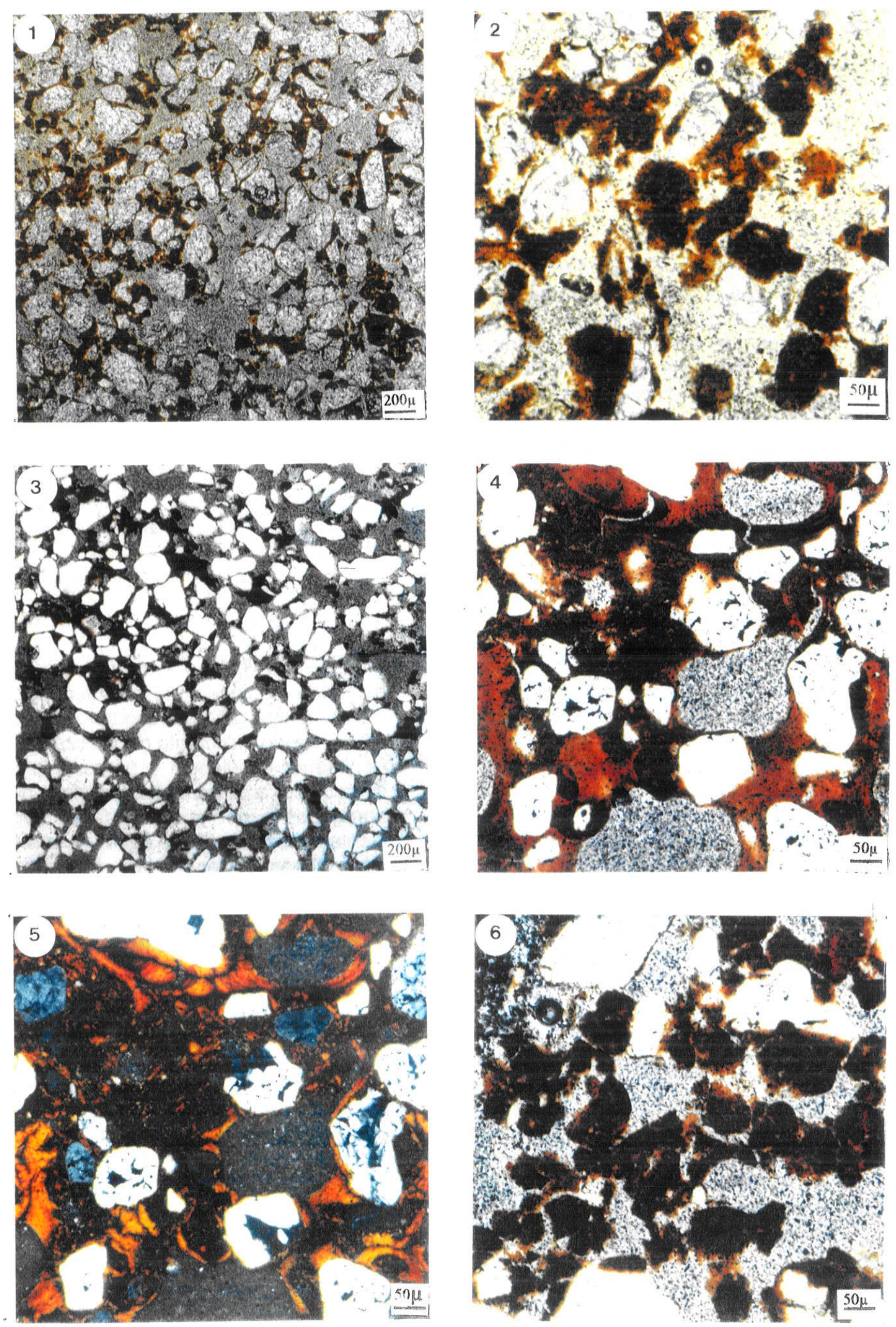


\section{TOPOSSEQÜENNCIA SIITIO TRÊS LEŐES}

Fotomicrografia 1: volume superficial com textura areia praticamente sem plasma, originando a estrutura de base mônica. No interior desse volume são encontradas glébulas ferruginosas de tamanho milimétrico oriundas da rocha subjacente (litorrelíquias).

Microscópio óptico, luz natural

Fotomicrografia 3: glébulas ferruginosas com princípio de alteração nas bordas evidenciado pelo plasma de cor brunoavermelhado-escura que grada para um plasma de cor bruno-escura (preto) em direção ao interior das mesmas. Entre as glébulas o plasma mantém as mesmas características do volume Bt. Microscópio óptico, luz natural

Fotomicrografia 5: características do esqueleto encontrado no interior das glébulas com plasma bruno-escuro (preto) com estrutura de base porfiritica. Observar a alternância de camadas de esqueleto fino e grosseiro semelhante a estratificação ocorrente no Arenito Caiuá sotoposto.

Microscópio óptico, luz natural
Fotomicrografia 2: glébulas ferruginosas praticamente sem alteração imersas numa matriz lavada semelhante à da fotomicrografia 1. Notar a diferença de tamanho das mesmas.

Microscópio óptico, luz natural

Fotomicrografia 4: glébula ferruginosa destruída. Verificar que no interior da mesma muitos gräos do esqueleto estão soltos, sendo facilmente remobilizáveis. No interior da glébula a porosidade é formada por empilhamento complexo de agregados e por microcavidades que facilitam a percolação da água. As cores mais claras correspondem às zonas onde o plasma está sendo mais facilmente remobilizado.

Microscópio óptico, luz polarizada

Fotomicrografia 6: arenito alterado com fissuras milimétricas parcialmente preenchidas por material mais fino de cor vermelho-alaranjada.

Microscópio óptico, luz natural 

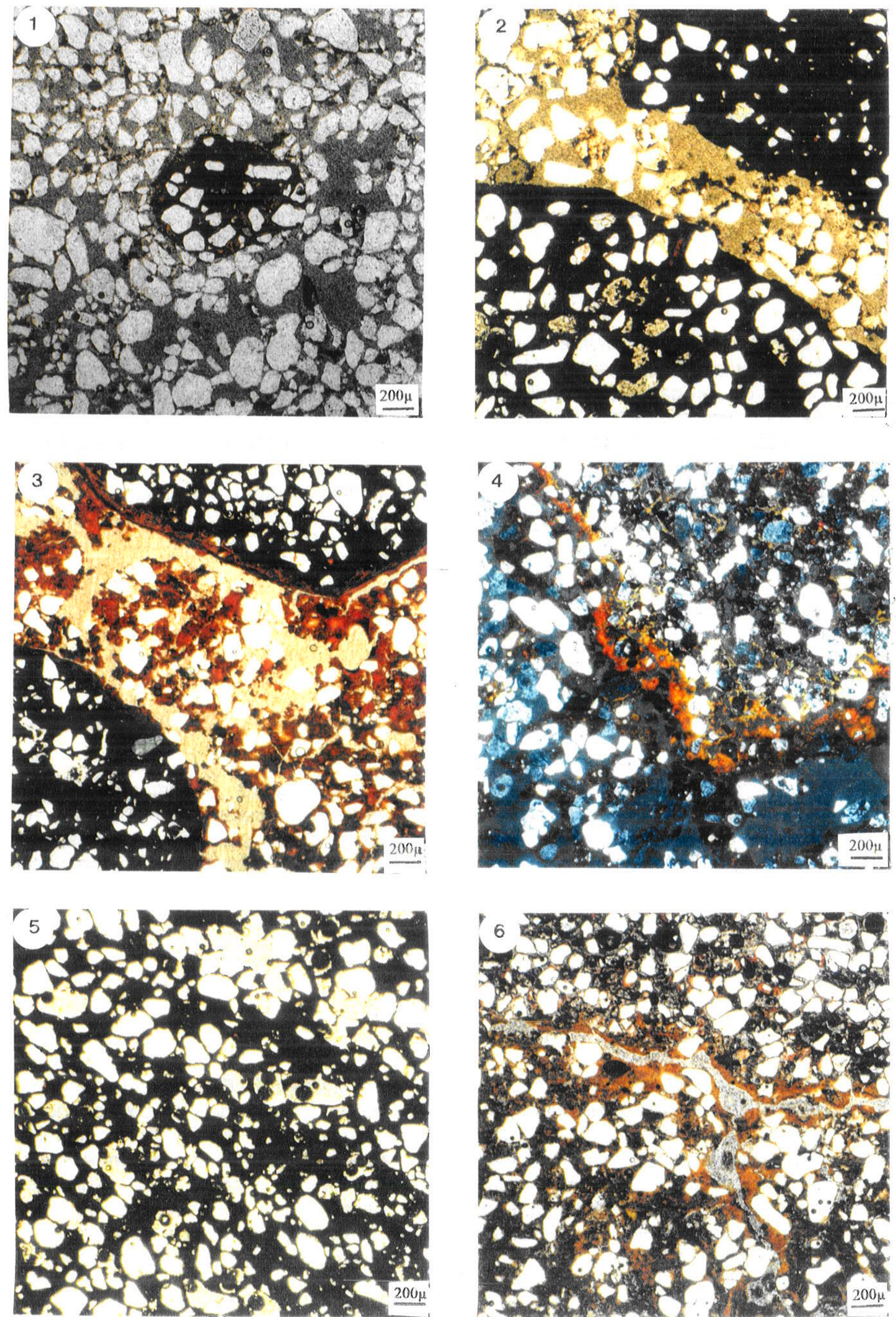
PRANCHA III

TOPOSSEQÜENCIA SITTIO TRÊS LEÖES

Fotomicrografia 1: volume superficial com plasma individualizado na forma de pequenos agregados que se distribuem de forma homogênea. O esqueleto é formado por grãos de quartzo das frações areia fina e muito fina desenvolvendo porosidade abundante. Microscópio eletrônico de varredura

Fotomicrografia 3: detalhe do volume B latossólico com plasma individualizado na forma de microagregados.

Microscópio eletrônico de varredura
Fotomicrografia 2: volume profundo ( $\mathrm{Bw})$ com maior concentração de plasma, que se distribui ora na forma de microagregados, ora como uma massa que recobre totalmente alguns grãos do esqueleto. Observar que a porosidade continua fortemente comunicante. Microscópio eletrônico de varredura
Fotomicrografia 4: característica do arranjo formado pelos grãos do esqueleto, destacando-se os espaços vazios que favorecem a livre circulação da água.

Microscópio eletrônico de varredura
Fotomicrografia 5: aspecto da superficie de um grão detrítico de quartzo com sinais de dissoluçäo química representada pela presença de figuras geométricas com forma de pequenos triângulos que se destacam em relevo. Microscópio eletrônico de varredura
Fotomicrografia 6: detalhe da superfície de um grão de quartzo com avançado grau de dissolução química, desenvolvendo cavidades com estrutura prismática. Sobre essa superfície desenvolvem-se filamentos de silica reprecipitada com aspecto de renda. Microscópio eletrônico de varredura 

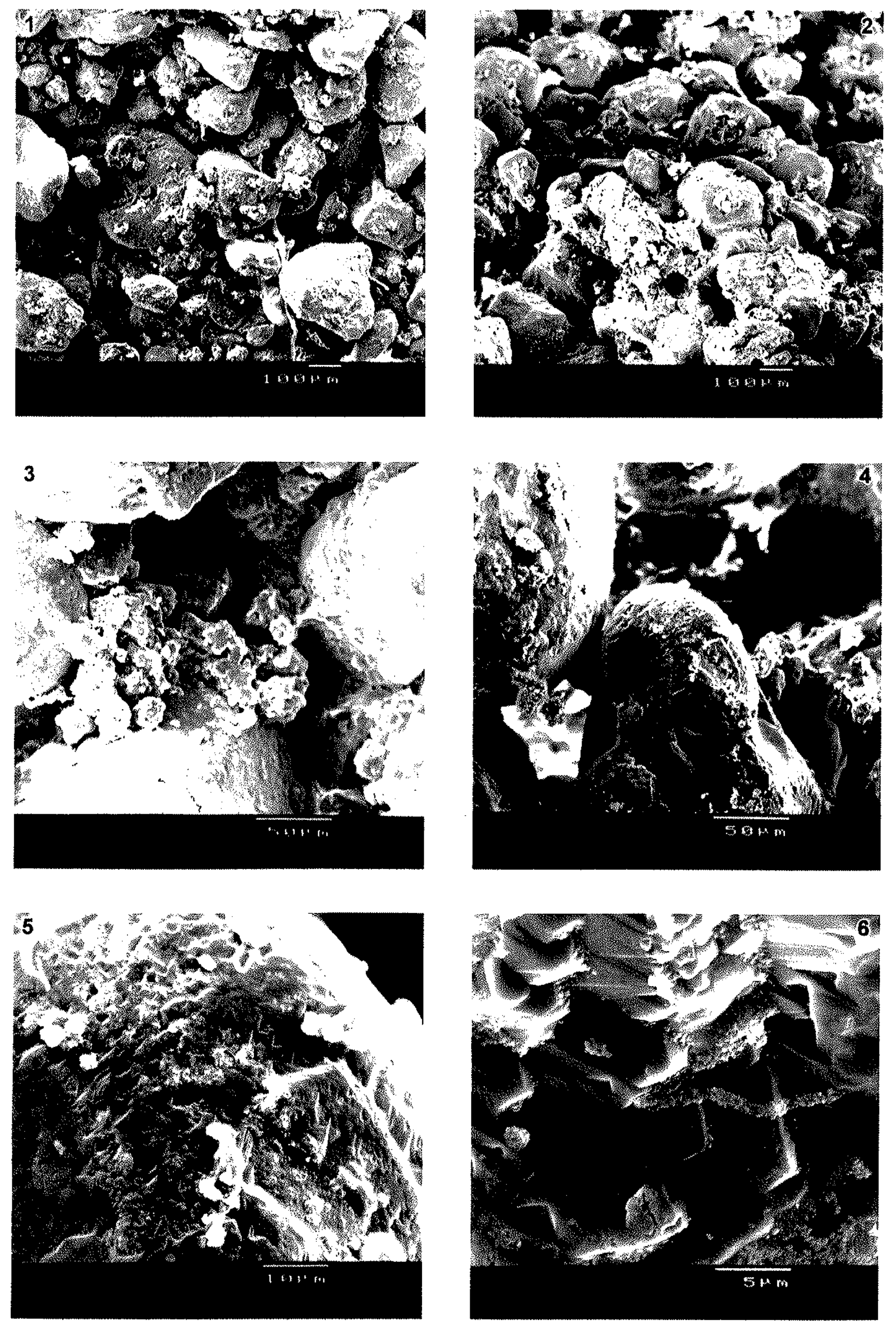


\section{PRNCHA IV}

\section{TOPOSSEQÜENNCIA SITIO TRÊS LEÕES}

Fotomicrografia 1: aspecto do volume Bt com aumento acentudo de plasma da cor bruno-avermelhada desenvolvendo a estrutura de base porfíritica. Os grãos do esqueleto estão totalmente imersos no plasma. A porosidade sofre uma redução acentuada com relação ao volume superior $(E)$, sendo formada pelas microfissuras e alguns pedotúbulos. É comum a presença de cutãs.

Microscópio eletrônico de varredura

Fotomicrografia 3: interior de uma glébula com plasma ferruginoso $(F)$ mais ou menos orientado ao redor dos grãos do esqueleto (Q). As cavidades lisas não são restos de cutãs mas superfícies originadas pelo desprendimento dos grãos do esqueleto. É comum a presença de cavidades e microfissuras. Microscópio eletrônico de varredura

Fotomicrografia 5: formas curiosas de material neoformado com a composição semelhante a do feldspato potássico no interior da glébula. A composição do material ao redor apresenta a composição da caulinita mais óxido de ferro.

Microscópio eletrônico de varredura
Fotomicrografia 2: detalhe do volume $\mathrm{Bt}$, onde o plasma junto à parede dos pedotúbulos está orientado, originando cutãs $(\mathrm{Ct})$. Isso evidencia várias fases deposição de argila. Noutros setores o plasma está fissurado em razão dos processos de umectação e ressecamento.

Microscópio eletrônico de varredura
Fotomicrografia 4: detalhe do interior de uma glébula onde 0 material com aspecto botrioidal apresenta a composição da hematita (F), enquanto aquele com forma de renda é composto predominantemente por caulinita (C). Microscópio eletrônico de varredura
Fotomicrografia 6: gibbsita bem cristalizada no interior de uma glébula ferruginosa.

Microscópio eletrônico de varredura 

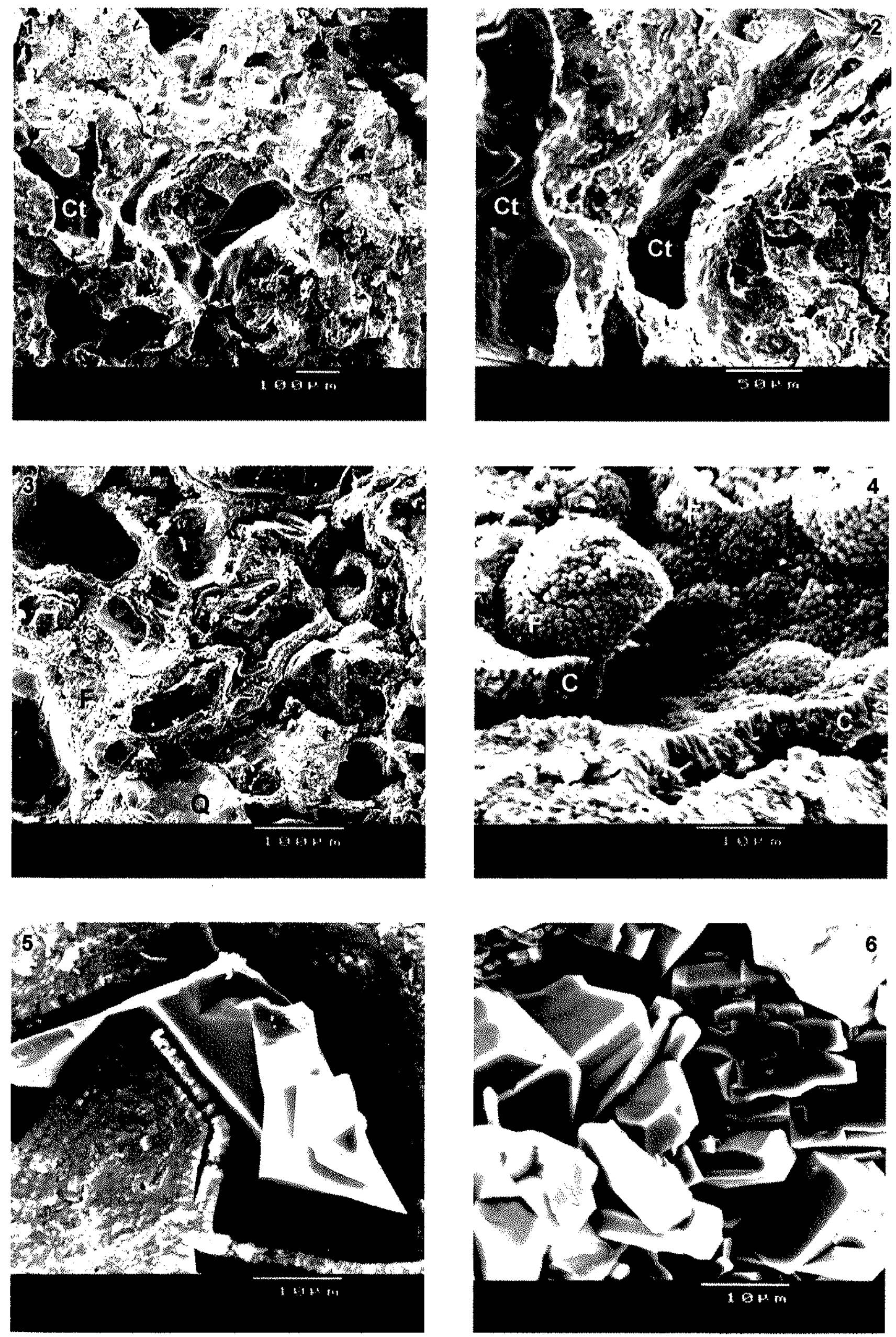


\section{PRANCHA V}

\section{TOPOSSEQÜÊNCIA SÍTIO TRÊS LEÕES - ARENITO CAIUÁ}

Fotomicrografia 1: visão geral do Arenito Caiuá alterado:

Microscóipio eletrônico de varrdura
Fotomicrografia 3: grão detrítico de quartzo recoberto parcialmente por uma fina película de material com a composição da caulinita mais óxido de ferro no arenito alterado.

Microscópio eletrônico de varredura
Fotomicrografia 3: restos preservados de feldspato potássico (Fk) encontrado no arenito alterado.

Microscópio eletrônico de varredura
Fotomocrografia 4: muscovita praticamente sem alteração imersa numa matriz formada por caulinita mais óxido de ferro no arenito alterado. Microscópio eletrônico de varredura 


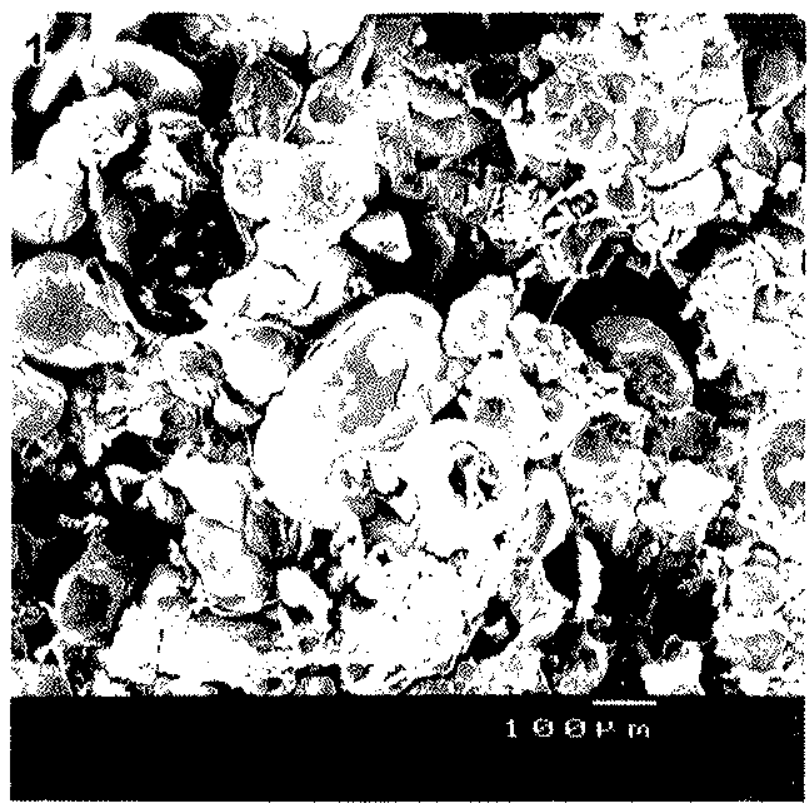

-- -

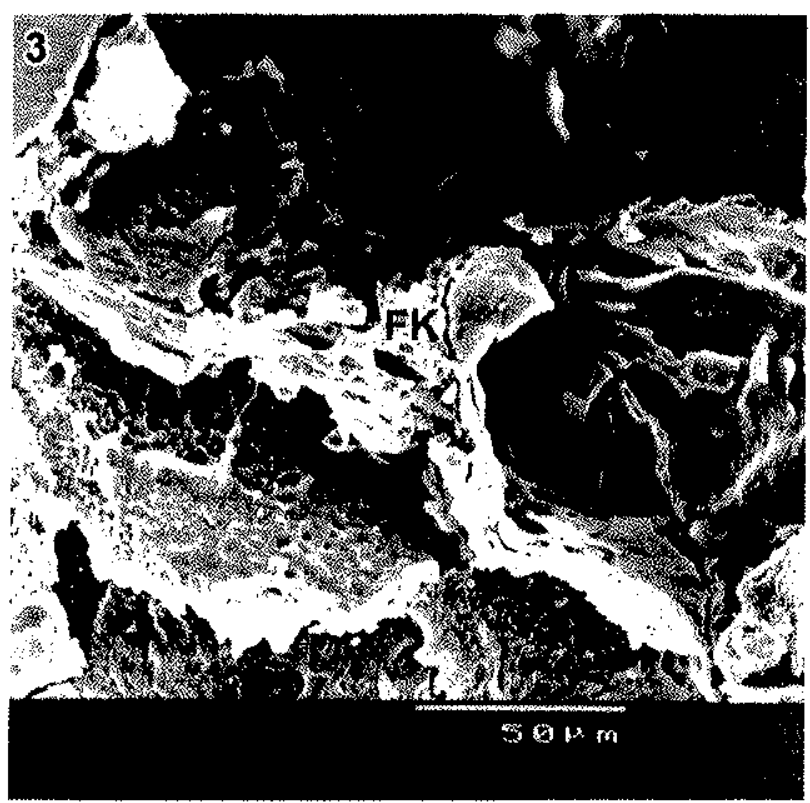

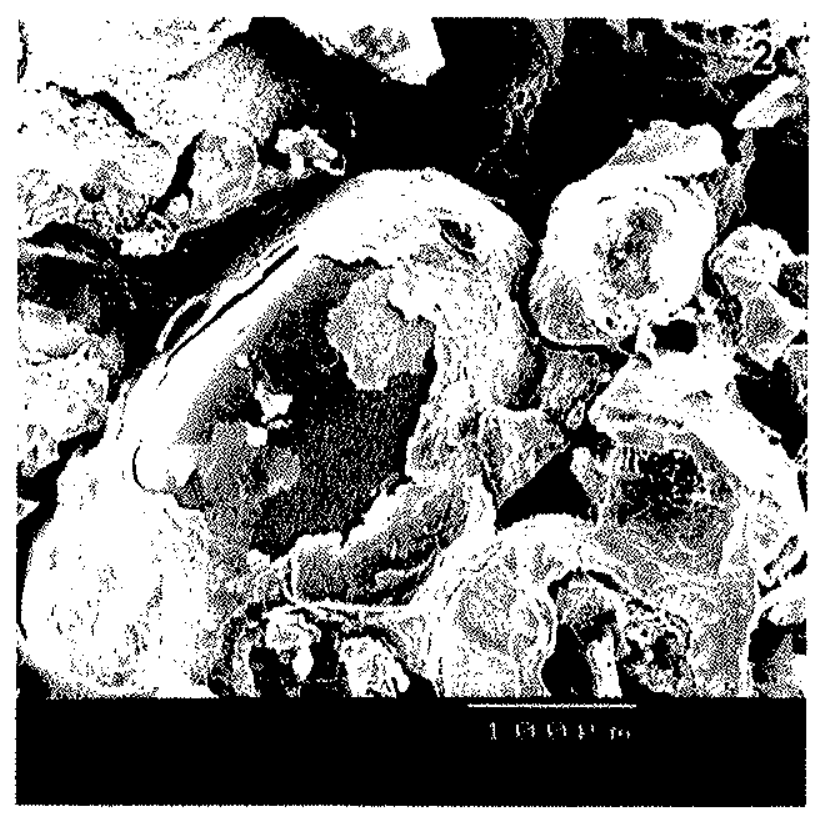

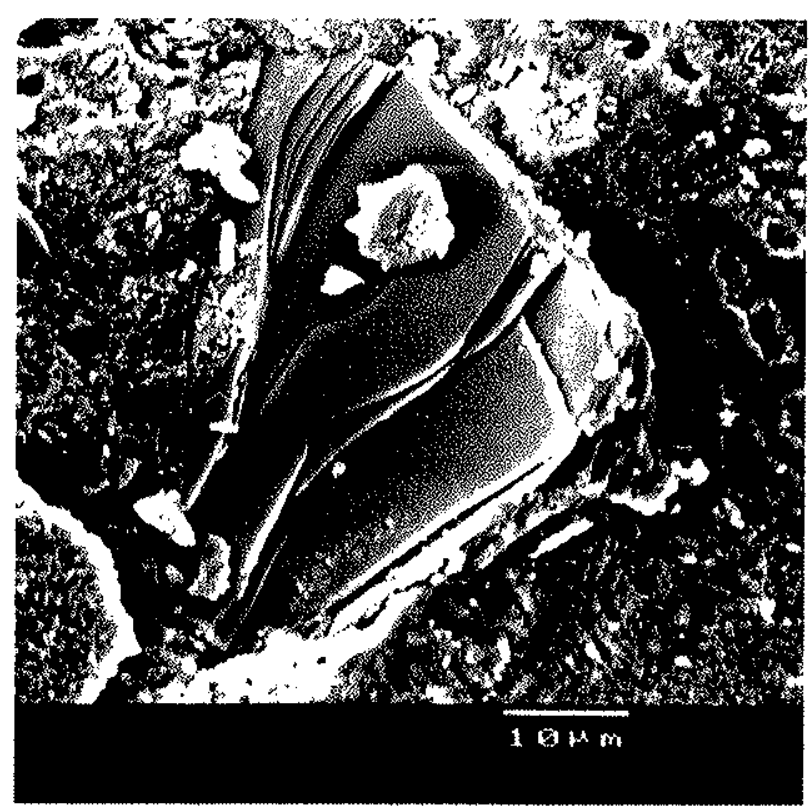




\subsection{Toposseqüência de Sumaré}

A toposseqüência de Sumaré está situada no topo do interflúvio principal que separa as bacias hidrográficas do rio Paranapanema, ao norte, e do rio Ivaí, ao sul. A área de estudo caracteriza-se por interflúvios amplos, com topos extensos e arredondados, relativamente planos. A vertente onde está localizada a toposseqüencia é longa, com declividade fraca (3\%), perfil convexo próximo ao topo, e com uma ruptura suave na média alta vertente, quando passa a ser ligeiramente côncava. Nessa posição do interflúvio, o final das vertentes não atinge os corrégos, terminando geralmente em longos vales em berço (Fig. 3.2).

Na Figura 3.2, observam-se, de montante para jusante, três volumes pedológicos principais: um superficial de textura areno-franca, um subsuperficial de textura franco-argiloarenosa ocorrendo apenas na média alta vertente, $e$, sotoposto a esses dois, um volume de textura franco-arenosa. Em razão de tal homogeneidade, essa toposseqüência não foi dividida em segmentos. No entanto, as descrições seguem o modelo proposto anteriormente, e as observações macro e micromorfológicas mais relevantes estão resumidas no Anexo 2.

O volume superficial, com espessura que varia de $20 \mathrm{~cm}$ a $60 \mathrm{~cm}$, se estende ao longo de toda a seqüência, apresenta cores que variam de bruno-avermelhada a vermelhoamarelada (5YR 4/4 a 4/6); textura areno-franca; estrutura que varia de subangular pequena fraca a maciça com grãos soltos; muito friável; não-plástica e não-pegajosa; porosidade abundante formada por empilhamento simples de grãos, além de alguns macroporos formados pela atividade biológica. Nesse volume, é comum a presença de pequenos bolsões (até $5 \mathrm{~cm}$ de diâmetro) de areia lavada de cor clara, e, também, de pequenos fragmentos de carvão vegetal. A transição para o volume sotoposto é clara em termos de cor.

Nesse volume o fundo matricial é formado por aproximadamente $5 \%$ a $10 \%$ de plasma, $50 \%$ de esqueleto e $45 \%$ de poros. O plasma sob luz natural apresenta cores que variam de bruno-escura a vermelha; sob luz polarizada, é isótico em pequenos aumentos, mas com aumentos maiores surgem setores sépicos com plasma reorganizado ao redor do 


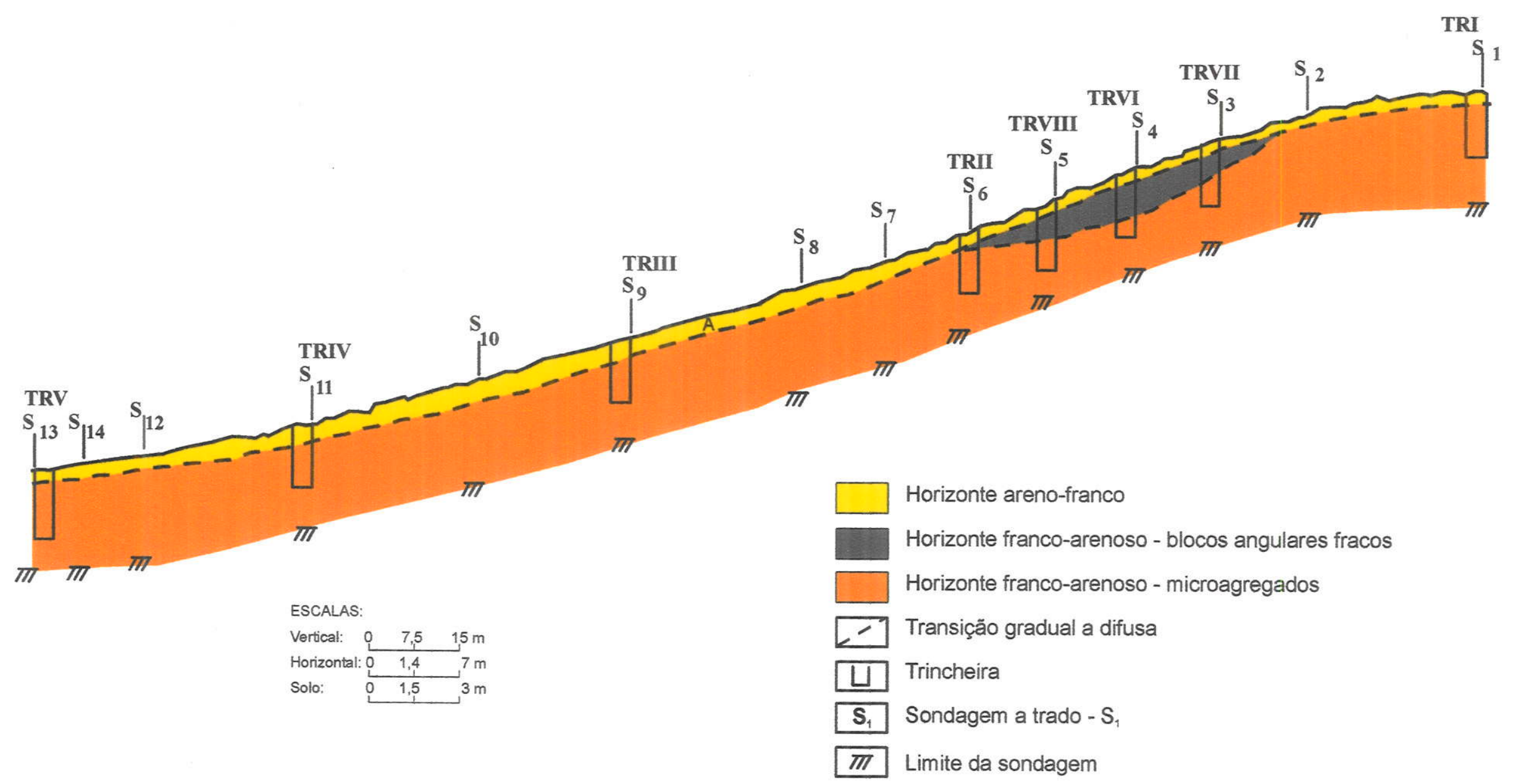

Fig. 3.2. Toposseqüência de Sumaré - Paranavaí 
esqueleto, originando estrutura plásmica do tipo granossépica. A estrutura de base entre o plasma e o esqueleto é predominantemente quito-gefúrica, mas podem ocorrer pequenos setores isolados com plasma mais concentrado ou mais lavado, desenvolvendo as estruturas de base porfírica e secundariamente mônica, respectivamente (PRANCHA VI Fotomicrografia 1). Observando-se a PRANCHA VII - Fotomicrografia 1, verifica-se que 0 plasma bruno-escuro não se distribui de forma uniforme; concentra-se junto aos poros ou forma uma fina película que envolve parcialmente os grãos do esqueleto. Outras vezes, acumula-se nas imperfeições dos grãos de quartzo e mais raramente na forma de microagregados.

O esqueleto é constituído essencialmente por grãos de quartzo, raros feldspatos, opacos e minerais pesados. A granulometria dos grãos detríticos de quartzo pode variar desde areia grossa até areia muito fina, pobremente selecionados. Em determinados setores das lâminas analisadas o esqueleto está agrupado e mais adensado. A porosidade é formada por empilhamento simples de grãos, fissuras, cavidades e canais fortemente comunicantes. A origem dessa porosidade é atribuída a processos pedogenéticos.

O esqueleto formado pela fração areia grossa apresenta microfissuras prenchidas por plasma. A presença dessas microfissuras geralmente está relacionada com dissolução de grãos, pelos processos de alteração química, chegando às vezes a uma fragmentação dos grãos do esqueleto (PRANCHA VI - Fotomicrografia 1 e PRANCHA VII Fotomicrografias 2 e 3). A fração areia grossa está restrita às posições de topo do interflúvio, diminuindo de forma acentuada à medida que se desce em direção ao fundo do vale. $O$ adensamento observado em alguns setores de algumas lâminas foi atribuído à intensa atividade agrícola a que está submetida a área de estudo.

A transição para o volume franco-arenoso é marcada pela mudança de cor, que se torna bruno-escura; a estrutura subangular a maciça com grãos soltos torna-se mais microagregada, acompanhada de um aumento de argila. Com relação ao volume francoargilo-arenoso, ocorre um aumento acentuado do plasma; as estruturas de base quitogefúrica e mônica, tipicas do volume superficial, dão lugar a estruturas de base quitogefúrica a porfírica aberta.

O volume subsuperficial profundo $(+350 \mathrm{~cm})$ é bastante homogêneo e se estende por toda a seqüência, apresenta cor vermelho-escura (2,5YR 3/6); textura franco-arenosa; 
estrutura que varia de subangular pequena fraca a maciça, que se desfaz em microagregados; muito friável; ligeiramente plástica a ligeiramente pegajosa; porosidade abundante constituida por empilhamento simples de grãos e macroporos de origem biológica formados principalmente por canais milimétricos, originados pela decomposição de antigas raízes. Da mesma forma que no volume superior, é comum a presença de pequenos bolsões de areia lavada, de cor mais clara, e de pequenos fragmentos de carvão vegetal.

Nesse volume, o plasma em luz natural apresenta cores que variam de brunoescura a bruno-avermelhada e pode atingir $15 \%$ do total dos constituintes. Sob luz polarizada e com pequeno aumento, é isótico, mas com aumentos maiores aparecem pequenos domínios tanto sépicos (argilassépicos) como assépicos (granossépicos, porossépicos). A relação entre o plasma e o esqueleto dá origem a estrutura de base predominantemente enáulica e mais raramente quito-gefúrica (PRANCHA VI Fotomicrografia 2 e PRANCHA VII - Fotomicrografia 2).

O esqueleto com teores em torno de $50 \%$ mantém as mesmas características do volume superficial, exceto em relação ao tamanho, que diminui para jusante. A porosidade é formada por empilhamento simples de grãos, cavidades, canais e fissuras, permanecendo fortemente comunicante.

Entre esses dois volumes, na média alta vertente surge um terceiro, mais argiloso, na forma de uma lente. Morfologicamente, esse volume apresenta cor vermelho-escura (2,5YR 3/6); textura franco-argilo-arenosa; estrutura subangular moderada fraca; friável; ligeiramente plástica a ligeiramente pegajosa; porosidade abundante formada por empilhamento simples de grãos e macroporos milimétricos originados pela decomposição de antigas raizes. Nesse volume, entre as faces estruturais dos agregados é comum ocorrer areia lavada de cor mais clara, que pode também preencher pequenos bolsões, poros tubulares e canais centimétricos de origem biológica.

O fundo matricial desse volume é formado por $20 \%$ de plasma, $40 \%$ de esqueleto e $40 \%$ de poros. O plasma, sob luz natural, apresenta cores que variam de brunoavermelhada a avermelha com tons alaranjados; sob luz polarizada, é isótico, mas destacam-se domínios sépicos (granossépicos e porossépicos). A estrutura de base é essencialmente porfírica aberta e secundariamente quito-gefúrica, e na maior parte das 
vezes está em franco processo de transformação, com a formação de microagregados que evoluem para a estrutura enáulica (PRANCHA VI - Fotomicrografia 3).

Os dominios sépicos apresentam, sob luz polarizada, orientação forte contínua, principalmente quando relacionados com reorganizações e/ou separações do plasma ao redor dos vazios e dos grãos do esqueleto (porossépicos e granossépicos), bem como junto aos cutãs. Aparecem alguns cutãs em processo de destruição em pequenas áreas (PRANCHA VI - Fotomicrografia 4). O plasma do fundo matricial, sob luz natural, apresenta cor bruno-escura e se distribui de forma homogênea por toda a lâmina; sob luz polarizada, é isótico. A cor do plasma que forma esses poucos cutãs, sob luz natural, é vermelho intenso; sob luz polarizada, apresenta orientação forte contínua (PRANCHA VI Fotomicrografias 5 e 6 ).

Na porção superior desse volume, o plasma bruno-avermelhado forma uma massa de aspecto "esponjoso", que envolve quase totalmente os grãos do esqueleto (PRANCHA VII - Fotomicrografias 4). Não se observam cutãs nem fissuras, enquanto na base o plasma torna-se essencialmente microagregado, originando pequenos agregados arredondados e individualizados semelhantes ao plasma encontrado no volume B latossólico.

A transição do volume franco-argilo-arenoso com o volume franco-arenoso sotoposto é marcada pela diminuição do plasma, pelo desmantelamento da estrutura de base porfírica, passando a predominar a enáulica, e também pelo desaparecimento quase total dos cutãs. 


\section{PRANCHA VI}

\section{TOPOSSEQÜENNCIA DE SUMARÉ}

Fotomicrografia 1: volume areno-franco superficial com plasma bruno-escuro desenvolvendo a estrutura de base quito-gefúrica. $O$ esqueleto mostra-se pouco selecionado onde os grãos maiores estão fissurados e incrustados com óxido de ferro. A porosidade é formada pelo empilhamento simples de gräos sendo fortemente comunicante. Microscópio óptico, luz natural

Fotomicrografia 3: aspecto do volume mais argiloso desenvolvendo estrutura de base porfírica aberta. Essa estrutura começa a sofrer processo de desmantelamento para dar origem a estrutura de base enáulica típica de solos com B latossólico.

Microscópio óptico, luz natural

Fotomicrografia 5: aspecto do plasma que forma os cutãs (brunoavermelhado), em constraste com o plasma do fundo matricial.

Microscópio óptico, luz natural
Fotmicrografia 2: volume franco-arenoso profundo (Bw), o plasma bruno-escuro forma microagregados, dando origem a estrutura de base enáulica. A porosidade é formada pelo empilhamento simples de grãos, sendo fortemente comunicante. Nas partes mais profundas do perfil ocorre uma redução da fração areia grossa. Microscópio óptico, luz natural

Fotomicrografia 4: detalhe da destruição de um cutã ocorrente no topo do volume mais argiloso.

Microscópio óptico, luz natural

Fotomicrografia 6: cutãs com orientação forte contínua realçando o plasma bruno-avermelhado, enquanto o plasma bruno-escuro é praticamente isótico. Microsópio óptico, luz polarizada 


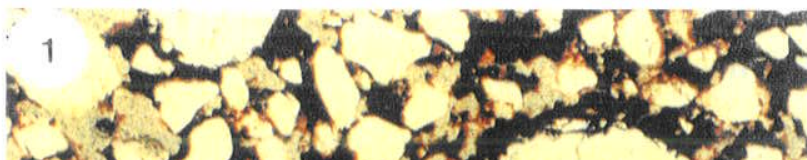
$1-2+3 x$

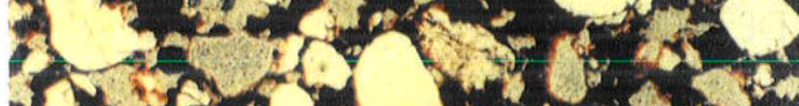
$f^{4}+5 \times 20$

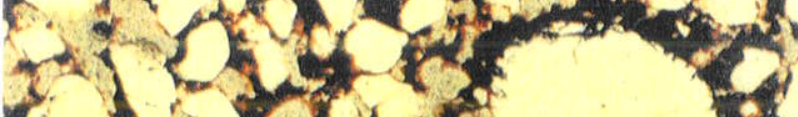
Shlat 20 te

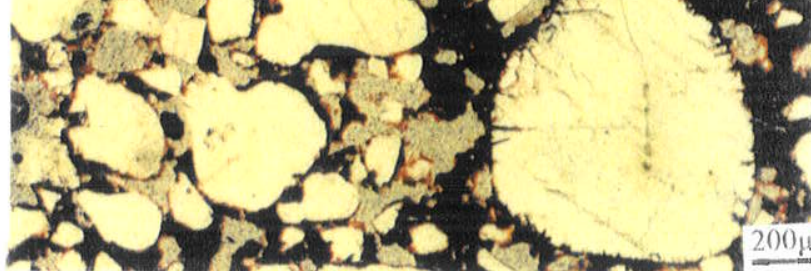

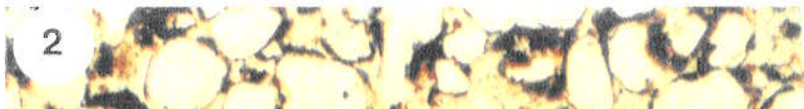

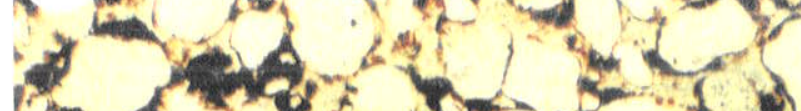

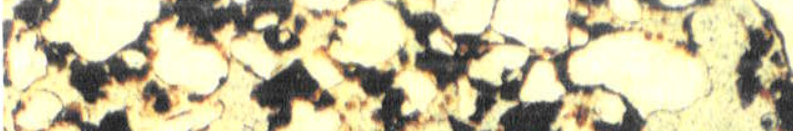

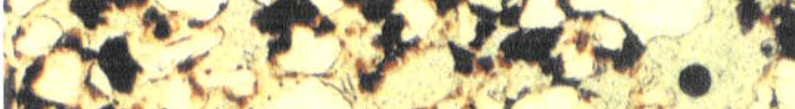
$242-5$ rat

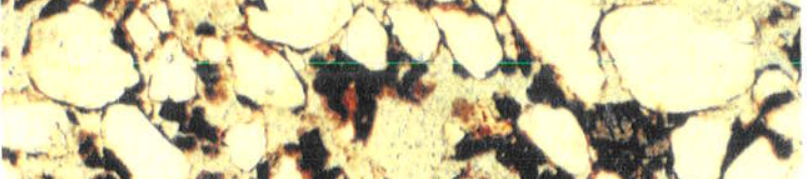
$x^{4}-12 x+2$

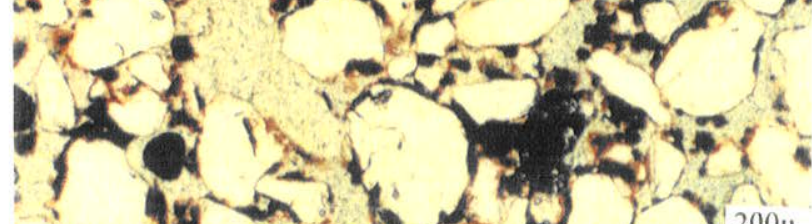
- $x^{2}+200 \times 200$
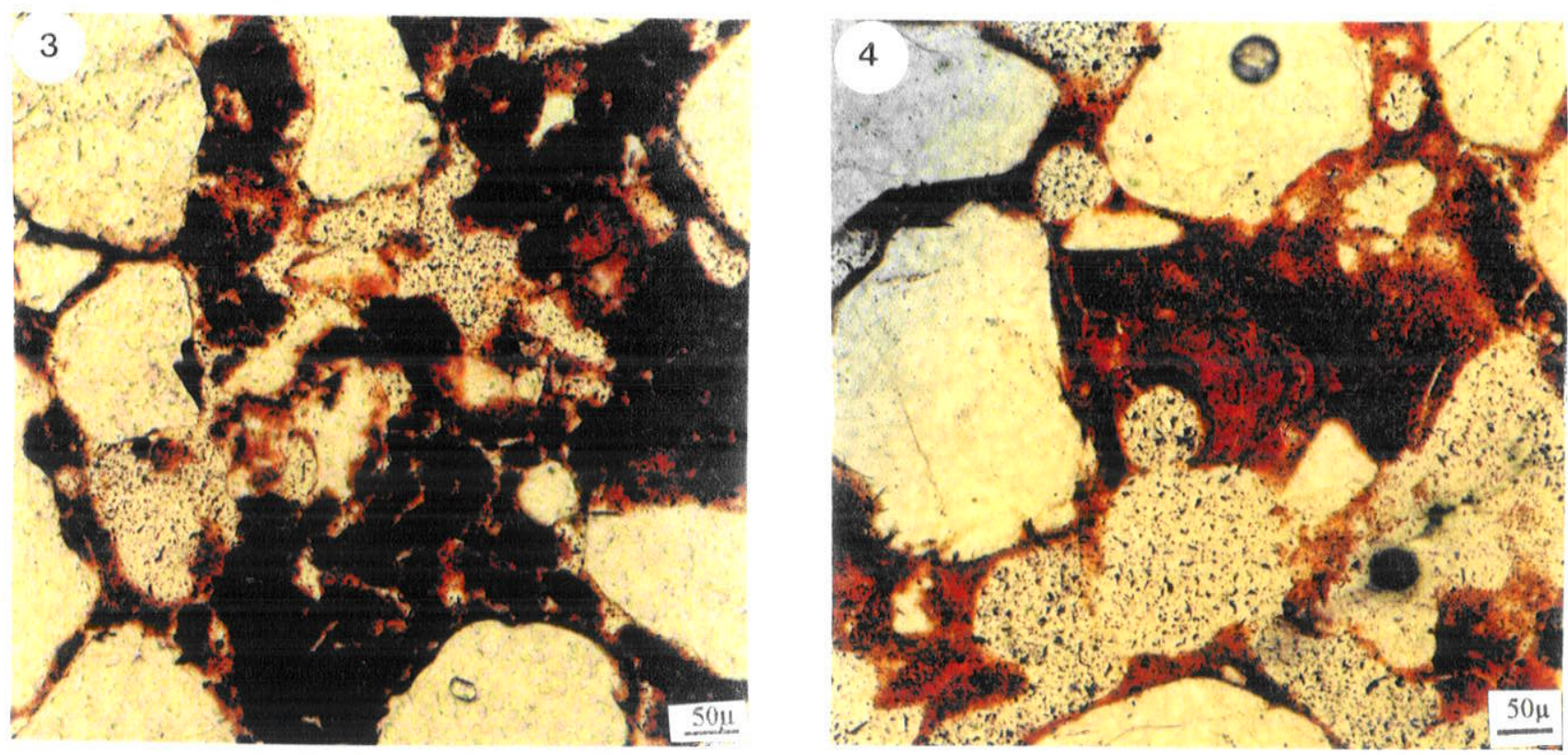
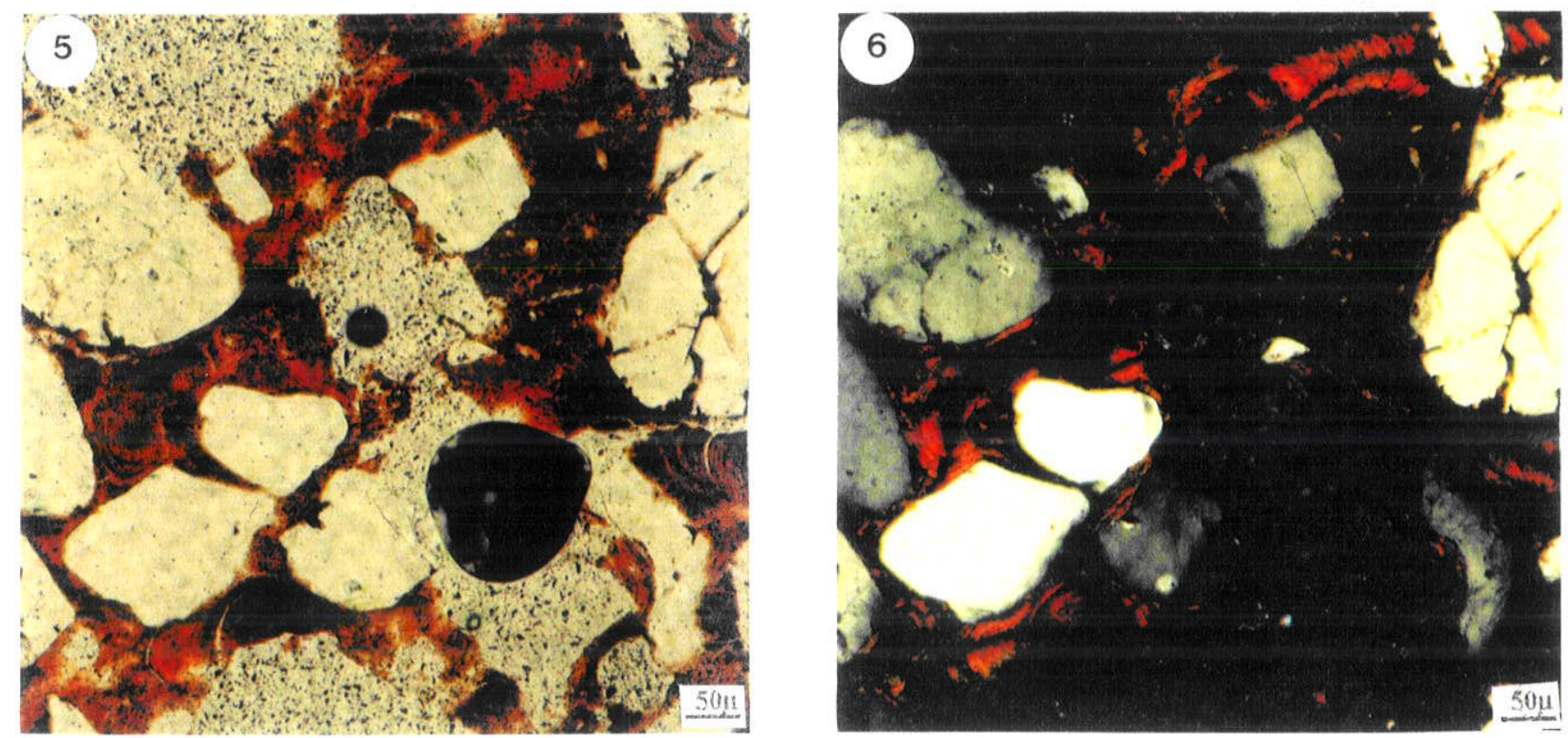
Fotomicrografia 1: volume superficial com plasma concentrado preferencialmente junto aos poros ou recobrindo com uma fina película os grãos do esqueleto.

Microscópio eletrônico de verredura
Fotomicrografia 2: grão detrítico de quartzo fissurado rodeado por microagregados arredondados bemdesenvolvidos.

Microscópio eletrônico de varredura
Fotomicrografia 3: cavidade de dissolução com forma geométrica semelhante a tetraedros parcialmente recobertos pelo plasma caulínitico mais óxido de ferro.

Microscópio eletrônico de varredura
Fotomicrografia 4: plasma com aspecto de uma massa esponjosa que cobre parcialmente os grãos do esqueleto no volume mais argiloso.

Microscópio eletrônico de varredura 

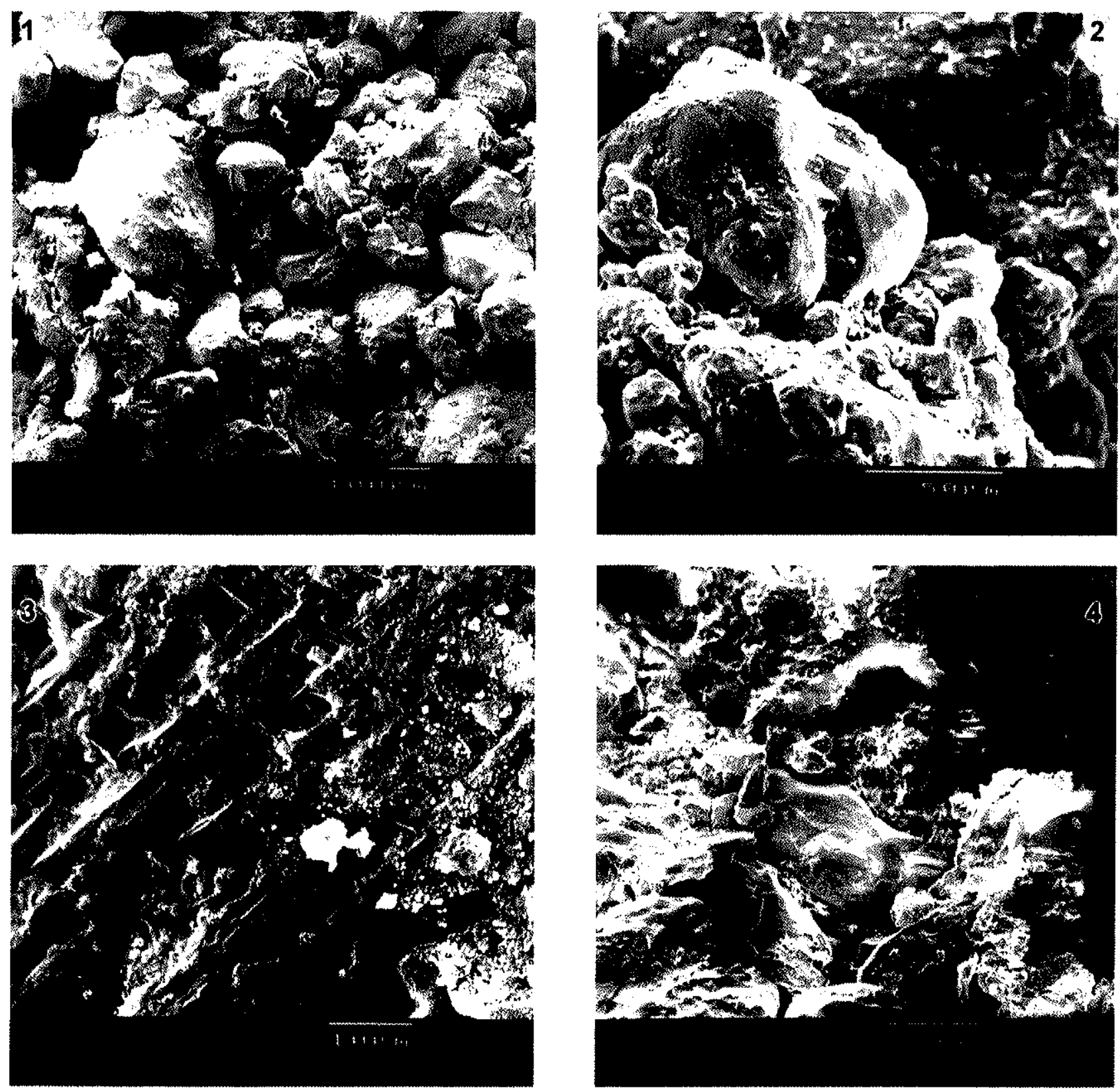


\subsection{Toposseqüência de Umuarama}

A toposseqüência de Umuarama também está localizada sobre o interflúvio das bacias hidrográficas dos rios Ivaí, ao norte, e do Piquiri, ao sul. Situa-se em uma colina de topo convexo pouco marcado, com cota de aproximadamente $500 \mathrm{~m}$, na margem esquerda do córrego Longe, afluente do córrego Pinhalzinho (Fig. 3.3). A vertente onde foi realizado o estudo é assimétrica e recoberta por vegetação de gramíneas. A síntese das descrições morfológicas e micromorfológicas está no Anexo 2.

Nesta toposseqüência ocorrem somente dois volumes pedológicos principais: um volume superficial de textura arenosa a areno-franca e um volume profundo de textura franco-arenosa, ambos se prolongando por toda a vertente. No sopé ocorre um depósito coluvial arenoso com $85 \mathrm{~cm}$ de espessura (PRANCHA VIII- Fotos 1 e 2). Tal como a toposseqüência anterior, também esta não foi subdividida em segmentos, porém as descrições seguem os mesmos moldes.

O volume superficial, com espessura em torno de $40 \mathrm{~cm}$, ocorre em toda a seqüência, apresenta cores que variam de vermelho-avermelhada a bruno-avermelhadoescura (5YR 3/4, 4/6 a 2,5YR 3/4, 3/6); textura arenosa a areno-franca; estrutura maciça com grãos soltos a subangular pequena fraca; friável; não-plástica a não-pegajosa; porosidade abundante formada pelo empilhamento simples de grãos e macroporos. $\hat{E}$ comum a presença de areia lavada de cor mais clara, fragmentos de carvão vegetal e raros nichos de insetos. A parte superior desse volume apresenta alternância de cores claras e mais escuras, enquanto na base ele é homogêneo. No final da vertente esse volume está coberto pelo depósito coluvial. Esse colúvio é composto por quatro camadas arenosas de pequena espessura.

A concentração de plasma do fundo matricial, no volume superficial, varia de $5 \%$ a $10 \%$, e o esqueleto pode alcançar $55 \%$, enquanto a porosidade pode atingir $45 \%$. $O$ plasma, sob luz natural, apresenta cor bruno-avermelhada com tons alaranjados; sob luz polarizada, é isótico com pequenos aumentos, mas com aumentos maiores surgem domínios sépicos (granossépicos, porossépicos) e assépicos (argilassépicos). A estrutura de base é variável, predominando a quito-gefúrica, mas em alguns setores o esqueleto está 


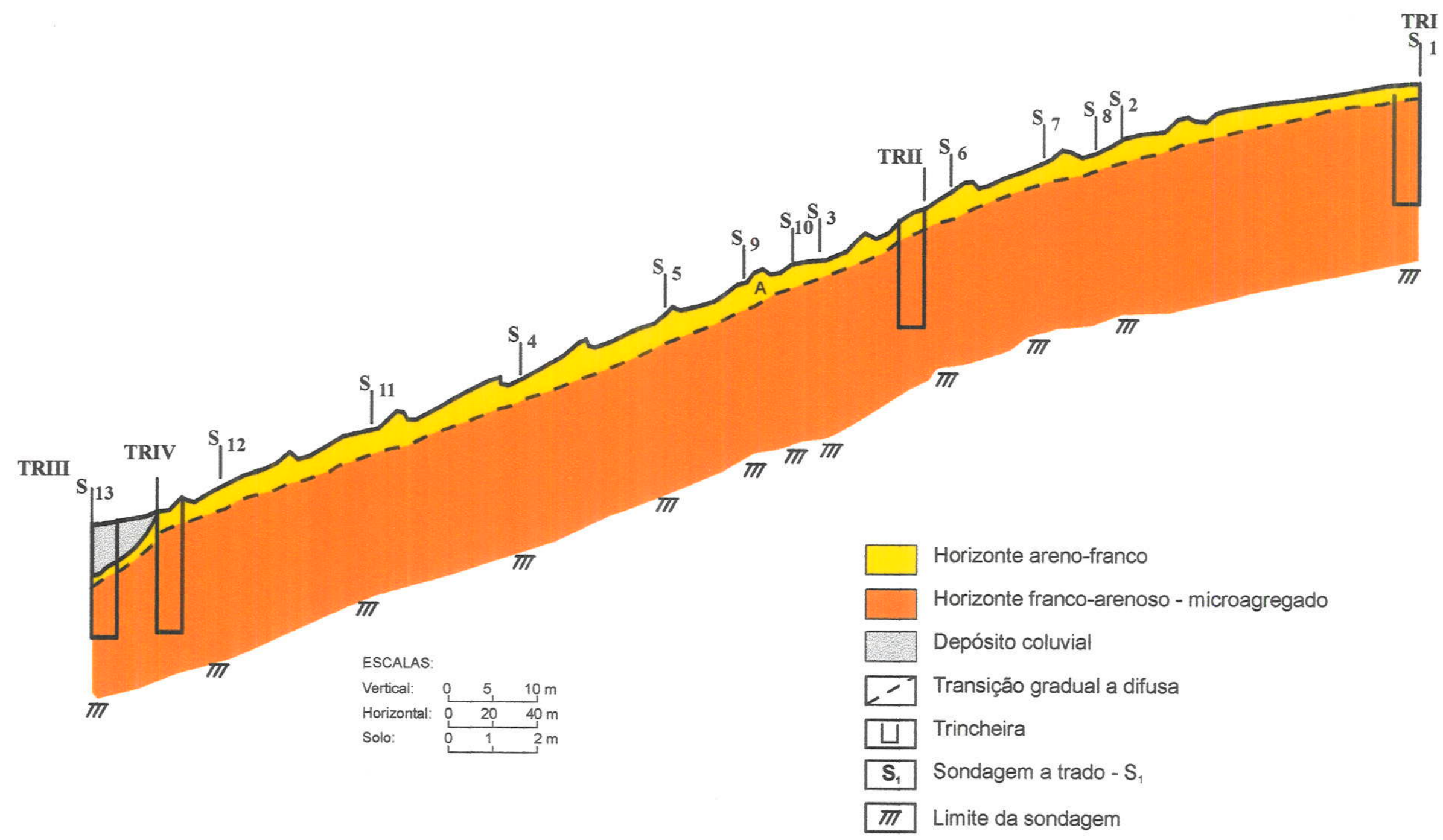

Fig. 3.3. Toposseqüência de Umuarama - Umuarama 
lavado (mônica), enquanto em outros o plasma apresenta-se concentrado em faixas e em manchas, semelhante a pequenos nódulos, dando origem à estrutura de base porfírica (PRANCHA IX - Fotomicrografia 1).

O esqueleto, composto essencialmente por grãos de quartzo das frações areia média e areia fina, apresenta uma distribuição ora homogênea, ora em faixas horizontais, moderadamente selecionados. A porosidade é formada por empilhamento simples de grãos, cavidades e canais fortemente comunicantes. A heterogeneidade na distribuição do esqueleto é atribuída à atividade agrícola. De modo geral, associada ao esqueleto mais fino, ocorre maior quantidade de plasma, preenchendo quase totalmente os poros.

A transição para o volume subsuperficial profundo é difusa plana e ocorre em razão da textura, que se torna mais argilosa; da predominância da estrutura microagregada, típica dos latossolos; da mudança da consistência mais friável e da diminuição da areia lavada.

O volume subsuperficial profundo $(+350 \mathrm{~cm})$ ocorre ao longo de toda a vertente, apresentando cor bruno-vermelho-escura (2,5YR 3/4); textura franco-arenosa; estrutura subangular pequena fraca, que se rompe em microagregados; muito friável; ligeiramente plástica a ligeiramente pegajosa; porosidade abundante formada por empithamento simples dos grãos, cavidades, fissuras e canais tubulares abundantes. É comum a presença de nichos de insetos centimétricos (até $5 \mathrm{~cm}$ de diâmetro) preenchidos por material mais argiloso e escuro, fragmentos de carvão vegetal, e de areia lavada na forma de pequenos bolsões, mas principaimente ao longo das fissuras.

Nesse volume, o plasma aumenta e pode ultrapassar $20 \%$ do total dos constituintes. $O$ esqueleto praticamente apresenta as mesmas proporções do volume superficial e alcança um máximo de $50 \%$, enquanto a porosidade varia em torno de $40 \%$. O plasma, sob luz natural, mostra cores que variam de bruno-escura a vermelha com tons alaranjados; sob luz polarizada, é isótico, porém com maiores aumentos verificam-se domínios sépicos (granossépicos e porossépicos), com orientação forte contínua, melhor observados quando o plasma está reorientado ao redor do esqueleto e dos poros. Quando o plasma ocorre formando uma fina película ao redor do esqueleto e, também, unindo os grãos do esqueleto através de pontes, desenvolve, conseqüentemente, a estrutura de base quito-gefúrica. Em outros setores, onde o plasma está bem individualizado, formam-se microagregados, originando a estrutura de base enáulica (PRANCHA IX - Fotomicrografia 
2).

O esqueleto distribui-se de maneira mais ou menos homogênea, com poucas exceções, quando a fração grosseira está agrupada. É formado basicamente pelas frações areia média e areia fina, moderadamente selecionadas. A porosidade é constituída por empilhamento simples, cavidades, canais e fissuras fortemente comunicantes. Sua origem foi atribuida a processos pedogenéticos.

O material coluvial é formado por quatro camadas de pequena espessura. No entanto, reveste-se de importância por apresentar uma distribuição granulométrica totalmente heterogênea ao longo do perfil, quando comparado com os solos da vertente. Os diferentes valores das concentrações granulométricas encontradas nas camadas podem ser utilizados como um parâmetro na identificação de materiais transportados ao longo das vertentes, uma vez que, para os solos desenvolvidos diretamente do material sotoposto, a distribuição granulométrica segue um padrão homogêneo e característico, observado nas diferentes áreas de estudo. Dessa forma, é possivel identificar de modo claro se o material que compõe as formações superficiais foi transportado ou derivou do próprio local.

Esses depósitos são constituidos por materiais arenosos, malselecionados, remobilizados principalmente pelas águas das chuvas e também por fluxos gravitacionais após a retirada da mata, depositados no fundo do vale. Mostram uma sucessão de camadas, que tendem a apresentar forma de cunha na direção dos paleofluxos, isto é, para os setores mais altos da vertente. Os contatos são abruptos e nitidamente erosivos. As camadas que exibem coloração mais escura apresentam indices mais elevados de argila associada à matéria orgânica, na forma de pequenas lentes milimétricas horizontais, decontínuas ou de nódulos argilosos. De modo geral, as maiores concentrações de argila estão associadas com as frações granulométricas mais finas (PRANCHA IX Fotomicrografias 3 e 4).

O contato entre as camadas é abrupto em termos de cor e textura, sendo comum o contato direto de frações granulométricas diferentes, ou então o material mais fino tende a preencher os espaços vazios (poros e cavidades) existentes entre os grãos mais grosseiros. No interior das camadas, os grãos detríticos de quartzo podem estar mais adensados e com maior quantidade de material argiloso, responsável pela maior dureza desses domínios. Em outros setores, o esqueleto apresenta-se menos adensado, 
desenvolvendo alta porosidade e características semelhantes aos solos da vertente (PRANCHA IX - Fotomicrografias 5 e 6 respectivamente).

As análises micromorfológicas evidenciaram que o material de origem nas três toposseqüências é o mesmo, provavelmente o Arenito Caiuá. O esqueleto não apresenta orientação, com exceção daquele encontrado no interior dos nódulos ferruginosos do final da toposseqüência do sítio Três Leões e na porção terminal da toposseqüência de Umuarama, onde se encontra $\mathrm{o}$ depósito coluvial. A ausência de orientação do esqueleto pode ser indicativo de que a alteração se processou diretamente do Arenito Caiuá sotoposto, sem nenhum deslocamento capaz de orientar os grãos do esqueleto. Essa homogeneidade na distribuição do esqueleto pode estar relacionada também à nãopresença de forças internas, principalmente do regime hídrico, que deveria ser estável no interior dos volumes, não permitindo o aparecimento de domínios orientados, bem como pela quase inexistência de minerais argilosos expansíveis.

A seqüência de distribuição dos solos, do sopé da vertente em direção ao topo, da toposseqüência do sítio Três Leões, define o seguinte sistema pedológico: Areias Quartzosas/Solo Podzólico Vermelho-Escuro/Latosso Vermelho-Escuro; enquanto para as toposseqüências de Sumaré e Umuarama, no mesmo sentido, aparece a seguinte organização pedológica Areias Quartzosas/Latossolo Vermelho-Escuro. 


\section{PRANCHA VIII}

TOPOSSEQÜENCIA DE UMUARAMA

Foto 1: visão geral do perfil de solo da TR-1 da toposseqüência de Umuarama. Notar a homogeneidade em termos de cor

Foto 2: depósito coluvial existente no final da toposseqüência de Umuarama. Observar as diferentes camadas $\left(C_{1}, C_{2}, C_{3} \in C_{4}\right)$, que se destacam pelas mudanças de cor 

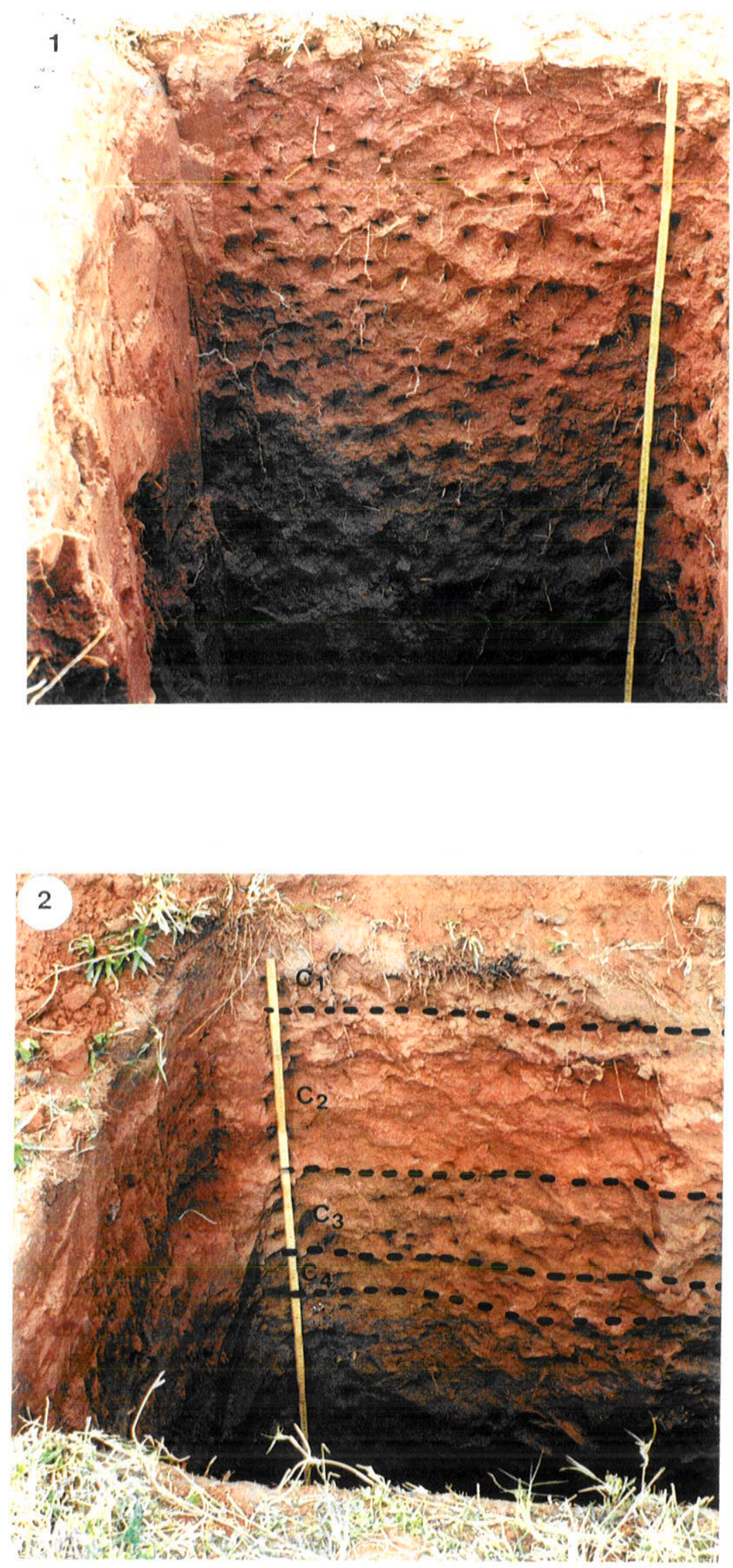


\section{TOPOSSEQÜÊNCIA DE UMUARAMA}

Fotomicrografia 1: volume francoarenoso superficial com plasma brunoescuro a avermelhado e estrutura de base predominantemente quito-gefúrica. Nos domínios mais concentrados pode ocorrer a estrutra de base porfírica. $O$ esqueleto mostra-se moderamente selecionado e a porosidade formada por empilhamento simples de grãos é fortemente comunicante.

Microscópio óptico, luz natural
Fotomicrografia 2: volume franco-argiloarenoso $(\mathrm{Bw})$ profundo com plasma microagregado. A porosidade é constrituida pelo empithamento simples de grãos, sendo fortemente comunicante. Esse volume se desenvolve ao longo de toda a toposseqüência.

Microscópio optico, luz natural
Fotomicrografia 3: material coluvial exibindo camadas com concentração de plasma diferente. $\mathrm{Na}$ parte superior da fotomicrografia as estruturas de base que predominam são a quito-gefúrica $e$ subordinadamente a mônica, enquanto na parte inferior destaca-se a estrutura porfírica.

Microscópio óptico, luz natural

Fotomicrografia 5: material coluvial mostrando uma camada com o equeleto adensado e redução acentuada da porosidade. O materiat mais fino tende a preencher a porosidade.

Microscópio óptico, tuz natural
Fotomicrografia 4: contato claro, entre as camadas que compó coluvial, realçado pela granutometria. Em geral o plasma mais relacionado com o esqueleto mais fino, enquanto 0 esqueleto mais grosseiro está mais lavado.

Microscópio óptico, turz naturat
Fotomicrografia 6: volume de Areias Quartzosas sob as camadas que formam o depósito coluvial. Observar o esqueteto pouco adensado com porosidade abundante, semelhante ao B tatossólico do topo.

Microscópio óptico, luz natural 


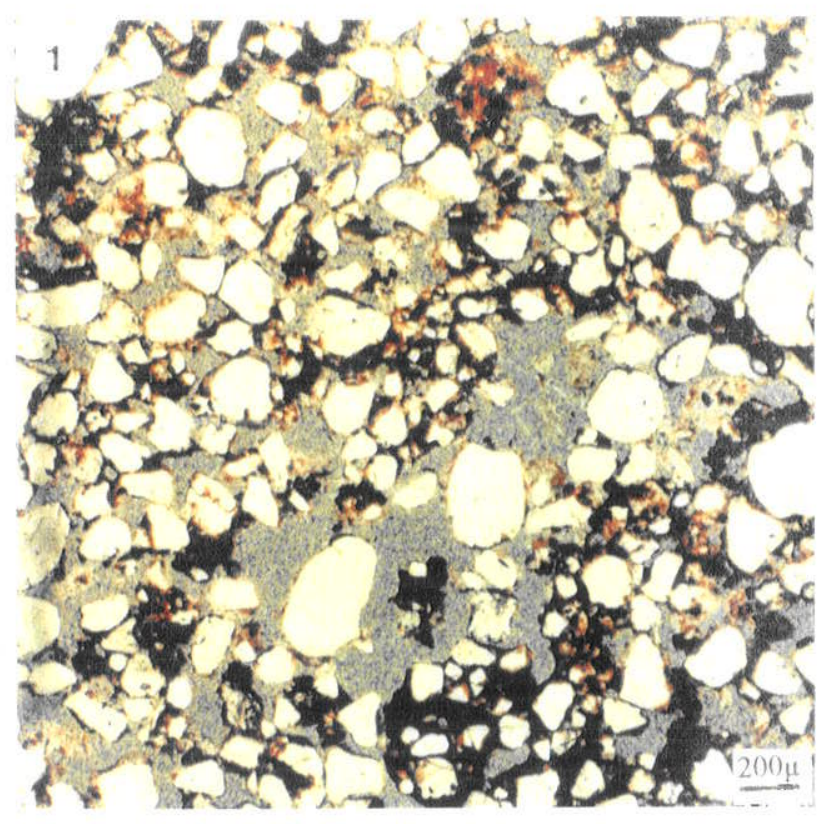

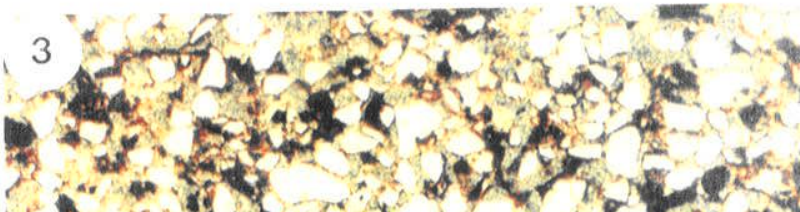

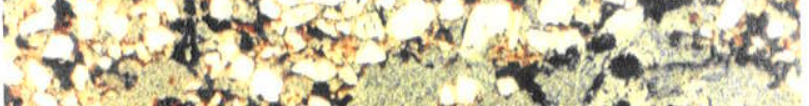

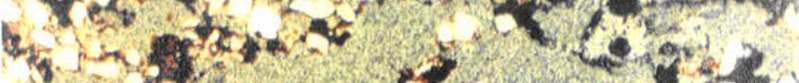

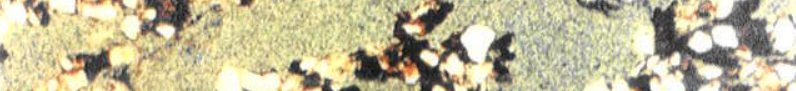

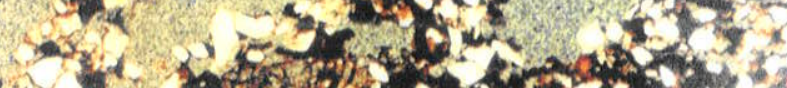

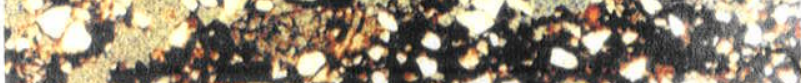

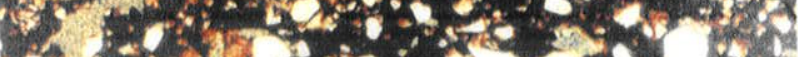

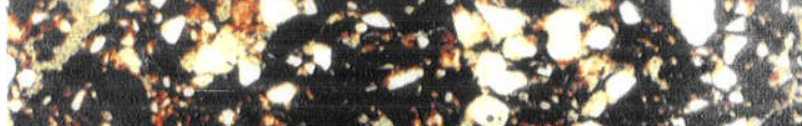

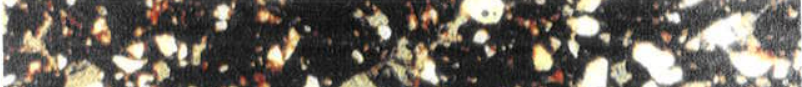

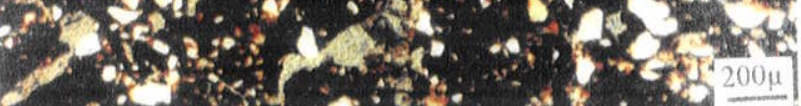

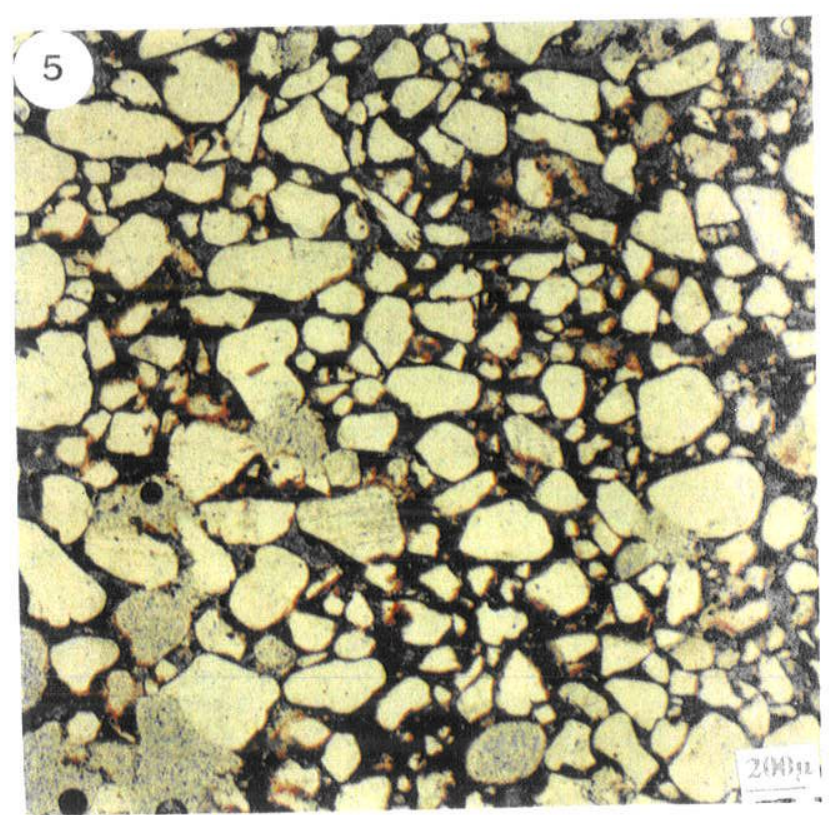

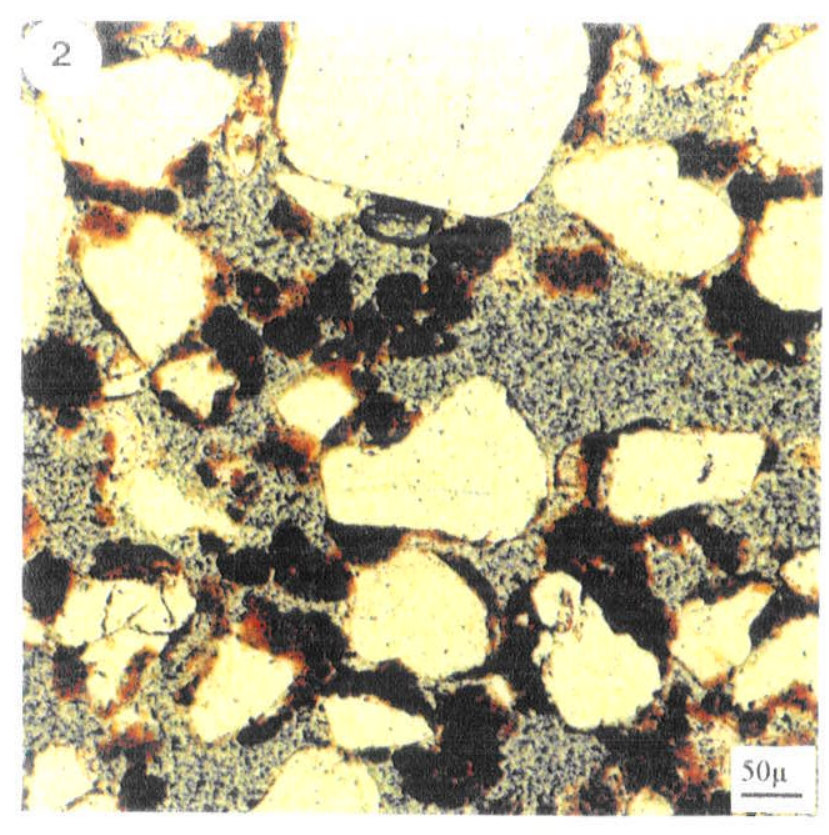
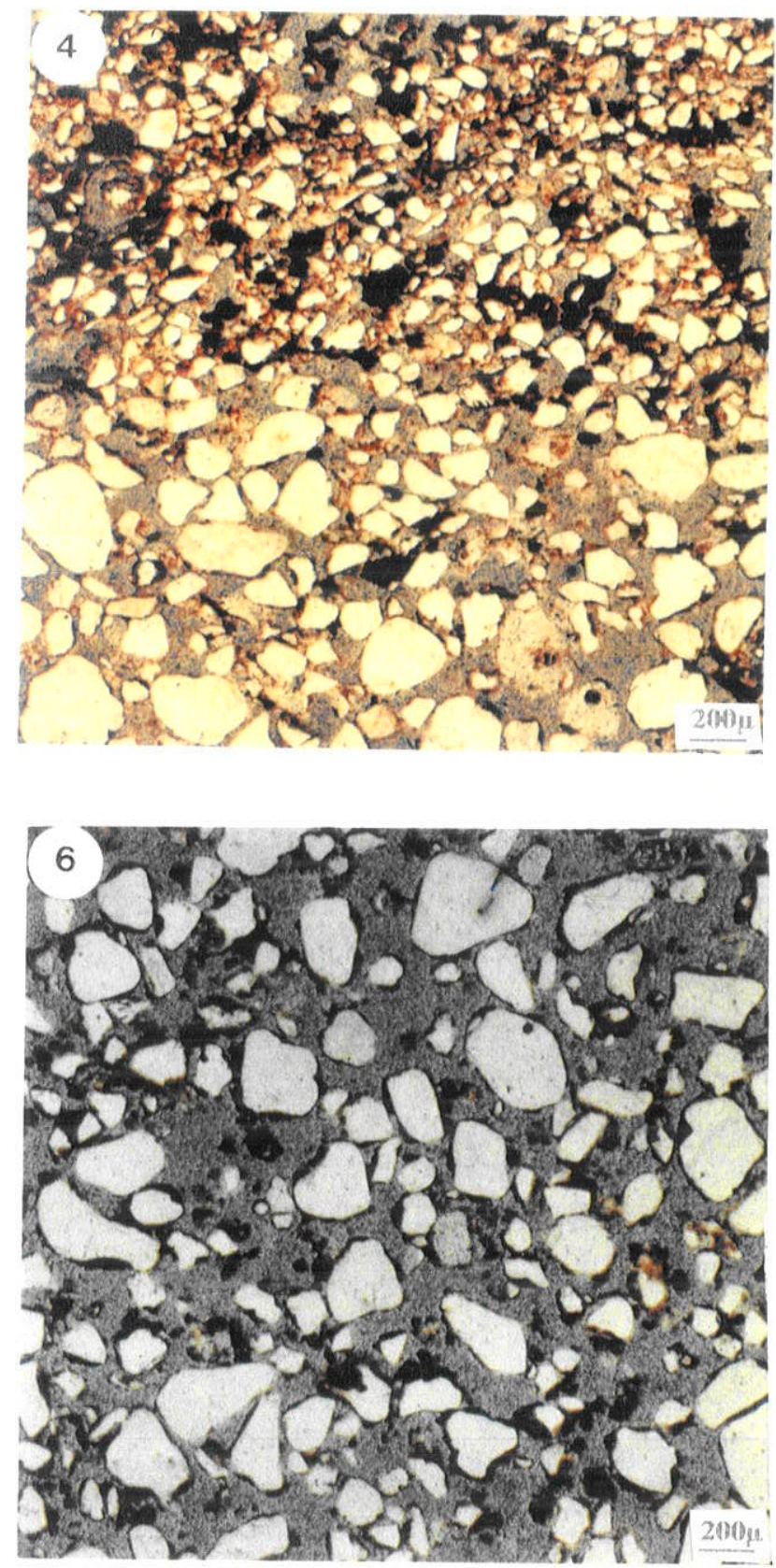


\section{Composição granulométrica}

Uma das preocupações deste trabalho foi realizar análises granulométricas detalhadas, com intervalos de $1 / 2 \varnothing$ (phi), dos materiais que compõem as formações superficiais e o Arenito Caiuá, uma vez que apresentam considerável importância quando se estudam sedimentos de origem clástica. A comparação das diferentes frações granulométricas ocorrentes nesses materiais, bem como sua distribuição, caracterizam-se por serem parâmetros indispensáveis quando se procura definir a filiação entre materiais.

Os dados obtidos através de análises granulométricas são de fundamental importância para a caracterização dos sedimentos, rochas sedimentares e solos. A textura, por exemplo, é definida com base na forma, tamanho e distribuição dos constituintes, que são muitas vezes suficientes para caracterizar materiais pedológicos ou mesmo auxiliar na identificação do modo como o material foi transportado, distância e ambiente de deposição (Dryden \& Dryden, 1946; Krumbien, 1941; Doeglas, 1968; Folk, 1954; Martins, 1967; Suguio, 1973; Brewer, 1964; Pettijohn, 1980; Giannini, 1987; Fernandes, 1992).

A partir dos métodos convencionais de análises granulométricas, foram determinados os teores de areia, silte e argila, para mostrar o comportamento dessas frações tanto em profundidade como ao longo da vertente. Também se determinou a relação de silte/argila; para Carvalho (1976), os valores obtidos dessa relação tendem a refletir a distribuição relativa dessas frações no perfil, bem como a exibir o seu comportamento na vertente.

\subsection{Toposseqüência do sítio Três Leões}

O Anexo 3 mostra os dados granulométricos percentuais dos perfis amostrados da toposseqüência, além de apresentar os valores da relação silte/argila. A Figura 3.4 representa a variação das frações com a profundidade dos perfis das trincheiras. 
$=0,500 \mathrm{~mm}$ ) praticamente não mudam na seqüência, e somente no terço inferior da vertente, em duas amostras da TR- IV, ultrapassam $1,0 \%$.

A areia média $(2,0 \varnothing=0,250 \mathrm{~mm})$, com teores um pouco mais elevados no máximo de 7,0\%, apresenta distribuição mais ou menos uniforme, com leve tendência a decrescer com a profundidade no perfil e também ao longo da vertente, até a TR-IV. Na TR-V, no final da vertente, devido à presença do arenito alterado, há grande variação dos valores, indo de 6,06\%, como matriz dos nódulos, até 1,0\% no arenito alterado, e desaparecendo praticamente na base da trincheira, a $110 \mathrm{~cm}$ de profundidade.

A fração areia fina $(3,0 \varnothing=0,125 \mathrm{~mm})$ predomina nos materiais pedológicos. Os valores mais elevados encontram-se no topo, na TR-I, onde alcançam $66,83 \%$, diminuindo de forma lenta e gradual para o fundo do vale e em profundidade no perfil. Na TR-IV, terço inferior da vertente, atingem o mínimo, alcançando $29,0 \%$. A jusante, na TR-V, os valores voltam a crescer, aproximando-se daqueles encontrados no Arenito Caiuá (50\%-60\%). Dos volumes pedológicos identificados, o que apresenta a menor concentração é o volume mais argiloso (Bt), mantendo valores praticamente idênticos nas TR-II e TR-III, localizadas na média vertente, e reduzindo-se ainda no setor com ocorrência de nódulos, enquanto o teor de argila aumenta, porém de forma moderada.

A areia muito fina $(4,0 \varnothing=0,053 \mathrm{~mm})$ tem comportamento inverso ao apresentado pela areia fina. Suas concentrações mais baixas são encontradas no topo (TR-I), em torno de $9,0 \%$, enquanto na TR-V, junto ao córrego, pode atingir o valor de $26,72 \%$. Sua distribuição do topo até o terço inferior é um tanto uniforme, com pequeno aumento na vertente e de forma pouco evidente no perfil. Entretanto, há dois pontos importantes a serem enfatizados. Na passagem da TR-I para a TR-II, as concentrações dessa fração evoluem de valores ao redor de $10,0 \%$ para valores em torno de $16,0 \%$, sendo que esses valores são mantidos para a TR-III. A partir da TR-III e, principalmente, nas TR-IV e V, ocorre um incremento, porém o decréscimo com a profundidade é claro, mostrando que realmente existe uma mobilidade dos materiais finos para jusante. As concentrações mais elevadas são melhor observadas nos volumes superfíciais, onde os valores são mais pronunciados, enquanto nos volumes mais profundos sua variação é moderada.

O comportamento do silte é semelhante ao da areia muito fina ao longo da vertente. Na porção mais alta do interflúvio, na TR-I, seus valores são baixos e variam de $2,72 \%$ a 
4,71\%; no fundo do vale, TR-V, alcança valores próximos de $14,0 \%$. Os valores mais elevados estão relacionados com amostras do arenito alterado existente na base das TR-IV e V, uma vez que nos volumes mais superficiais das referidas trincheiras seus valores são menores e compativeis com os encontrados ao longo da seqüência.

Pela distribuição da argila, fica claro que existe uma separação entre os volumes superficiais arenosos e os volumes mais profundos argilosos. Os volumes superfíciais perdem lateraimente argila ao longo da vertente; isso fica evidente quando são comparados os dados de sua concentração, na TR-I 14,28\%, reduzindo-se para $4,77 \%$ na TR-V, no sopé da vertente. Portanto, os volumes superfíciais perdem argila ao longo da seqüência. Ao mesmo tempo em que a argila é mobilizada dos volumes superfíciais, ocorre uma acumulação nos volumes mais profundos, dando origem a um volume $B$ textural, que tem início na média alta vertente e se avoluma para jusante, tendo a máxima expressão na TRIII. Entre as TR-IV e V, começa a sofrer uma redução de espessura, transformando-se no volume arenoso superficial, que nesse local torna-se mais espesso. O valor mais elevado de argila ocorre no final do volume Bt, junto ao contato com a rocha alterada, sob a massa nodular, onde atinge $32,05 \%$. A partir desse ponto, até o córrego, há sinais de remobilizações da argila e também dos compostos férruginosos, evidenciados pela perda da cor avermelhada e pelas baixas concentrações da argila, que nesse setor da vertente atinge o valor mínimo de $4,77 \%$.

Em síntese, analisando-se a Fig. 3.4, observa-se que do topo até a média vertente (TR-I, TR-II e TR-III) há predomínio da fração areia fina; perda gradual de argila do horizonte superficial ao longo da vertente; enrriquecimento gradual a partir do volume superficial, em profundidade e ao longo da vertente, dos teores de argila e areia muito fina, culminando na TR-III com a individualização de um Bt, bem característico. A redução gradual ao longo do perfil e da vertente observada para areia fina se dá, principalmente, em detrimento do enriquecimento em argila e em areia muito fina. Enquanto no terço inferior (TR-IV e TR-V) ocorre redução siginificativa, em profundidade, dos teores de areia fina, acompanhada por aumento significativo de areia muito fina e silte nas proximidades do arenito alterado e redução lateral dos teores de argila em direção ao sopé, coincidindo com a destruição do Bt e do volume nodular e conseqüente espessamento do volume arenoso superficial. 

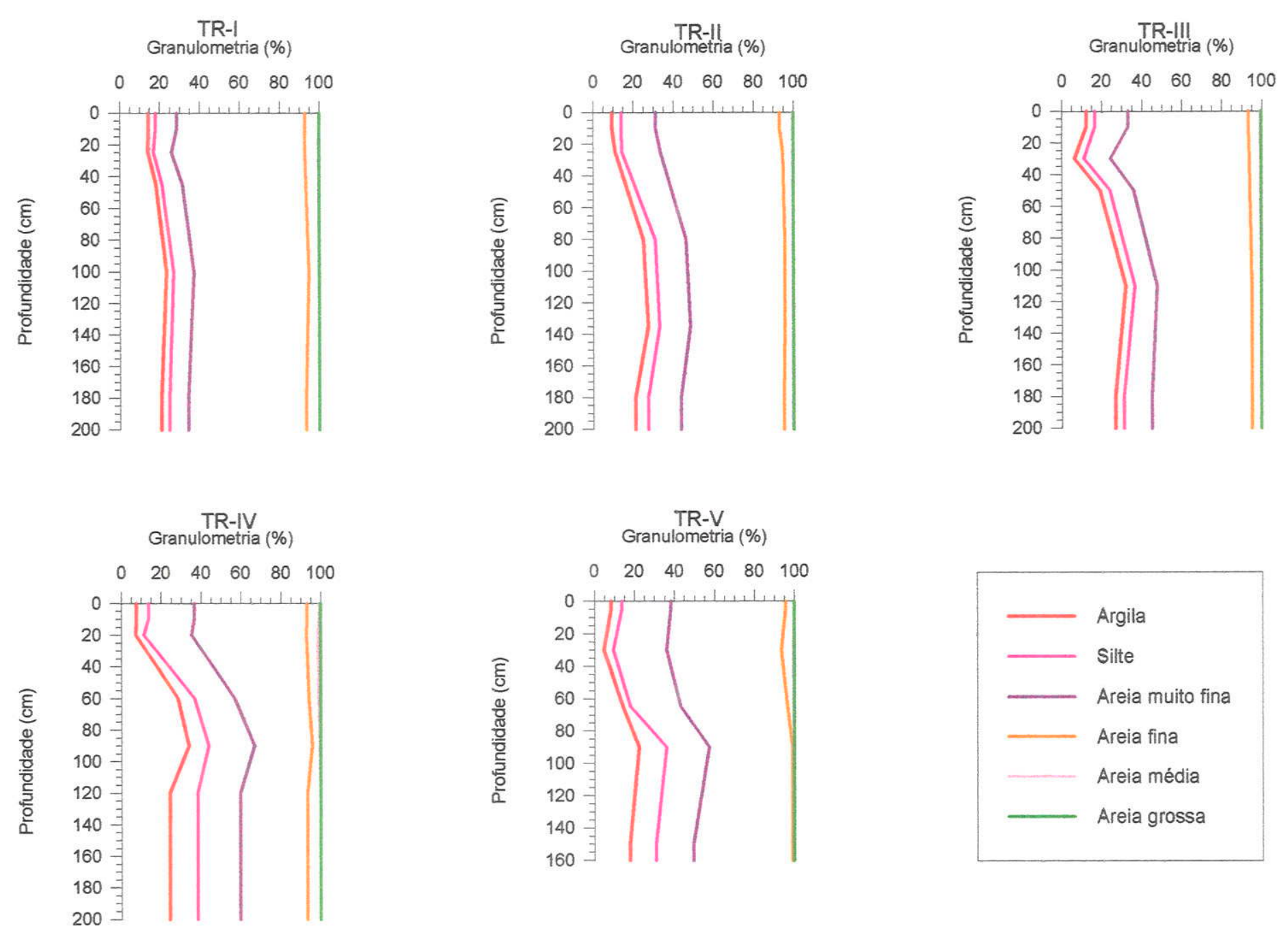

Fig. 3.4. Distribuição vertical das frações granulométricas ao longo da toposseqüência do sítio Três Leões 


\subsection{Toposseqüência de Sumaré}

Através dos dados do Anexo 3 e observando-se a Fig. 3.5, verifica-se que a toposseqüência de Sumaré diferencia-se das demais pela presença de constituintes mais grosseiros, que fazem parte das formações superficiais.

No topo do interflúvio, na TR-l, verifica-se a ocorrência de areia grossa com teores que variam de $6,27 \%$ a $10,57 \%$, no perfil. Na toposseqüência, esses teores diminuem para jusante, reduzindo-se de forma drástica já na TR-VII (alta vertente). Sua presença restringe-se, portanto, aos setores mais altos do espigão principal e tende a desaparecer em direção ao sopé da vertente.

Verifica-se ainda a ocorrência significativa da areia média, juntamente com a fração areia fina. São as frações predominantes no material, ao longo de toda a toposseqüência. Essas duas frações, de modo geral, apresentam teores maiores nos horizontes superficiais, diminuindo ligeiramente em profundidade, sempre em detrimento, principalmente, do aumento do teor de argila. Ao longo da toposseqüência, a partir da média baixa vertente, início do setor côncavo, os teores de areia média aumentam em todo o perfil, suplantando por vezes aqueles da areia fina, enquanto os da areia fina e muito fina diminuem.

A fração areia fina predomina em todo o setor de topo até a média vertente, com teores que variam de $34,38 \%$, na TR-IV, até $53,05 \%$, na TR-II.

As concentrações da fração areia muito fina são baixas, e sua distribuição no perfil é bem uniforme; contudo, na seqüência, seus teores são mantidos até o terço inferior, diminuindo a partir daí até o sopé da vertente.

Os teores de silte são os mais baixos encontrados entre as toposseqüencias estudadas, e o seu comportamento praticamente não sofre alterações significativas tanto no perfil como ao longo da vertente. Sua distribuição, embora reduzida, assemelha-se à da areia muito fina.

A distribuição da argila, nessa toposseqüência, é um tanto anômala, pois concentra-se em maiores proporções nas trincheiras do terço superior da vertente. Os maiores teores são encontrados nas trincheiras VII, VIII e II, onde podem alcançar $22,58 \%$. 
TR-I

Granulometria (\%)

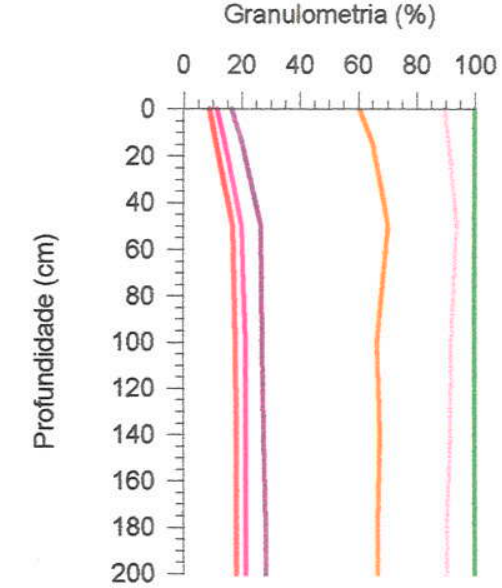

TR-II

Granulometria (\%)

$\begin{array}{llllll}0 & 20 & 40 & 60 & 80 & 100\end{array}$

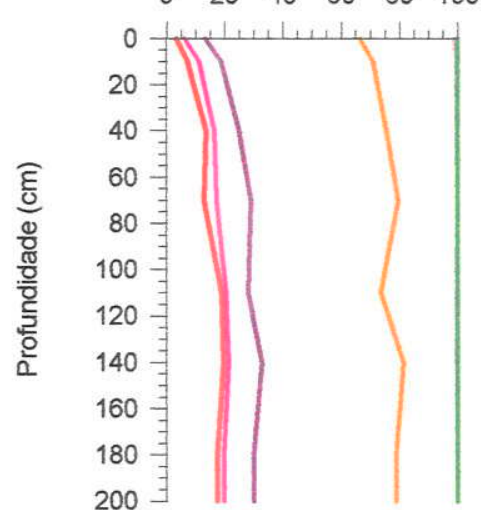

TR-VI

Granulometria (\%)

$\begin{array}{llllll}0 & 20 & 40 & 60 & 80 & 100\end{array}$

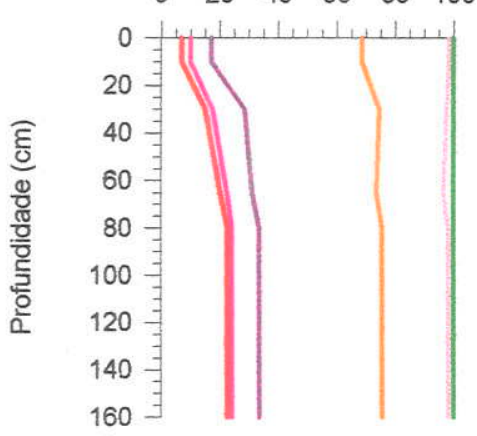

TR-II

Granulometria (\%)

$\begin{array}{llllll}0 & 20 & 40 & 60 & 80 & 100\end{array}$

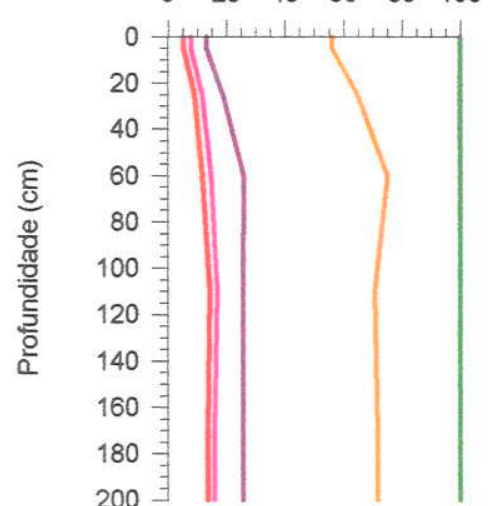

TR-VII

Granulometria (\%)

$\begin{array}{llllll}0 & 20 & 40 & 60 & 80 & 100\end{array}$

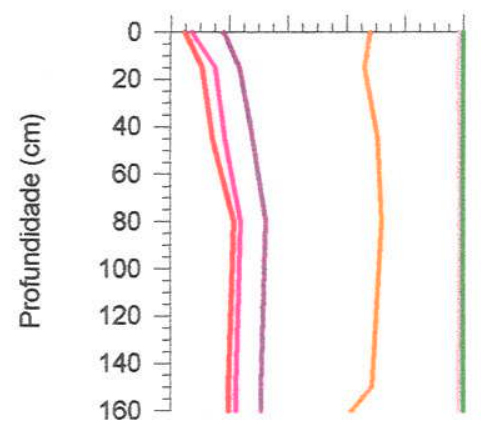

Granulometria (\%)

$\begin{array}{llllll}0 & 20 & 40 & 60 & 80 & 100\end{array}$

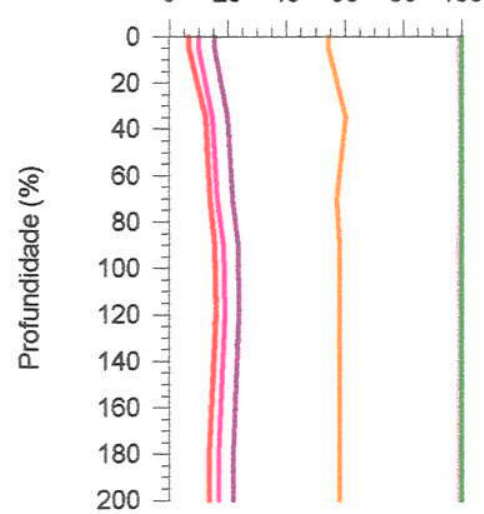

TR-VIII

Granulometria (\%)

$\begin{array}{lllll}20 & 40 & 60 & 80 & 100\end{array}$

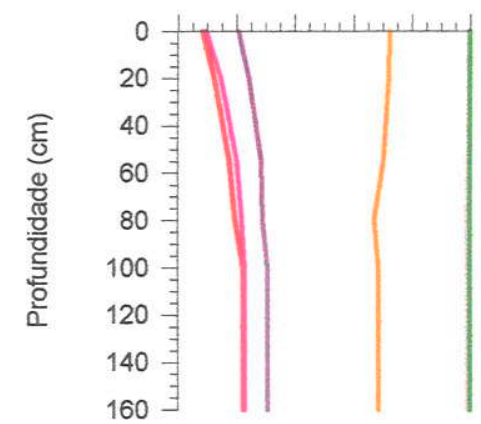
Granulometria (\%)

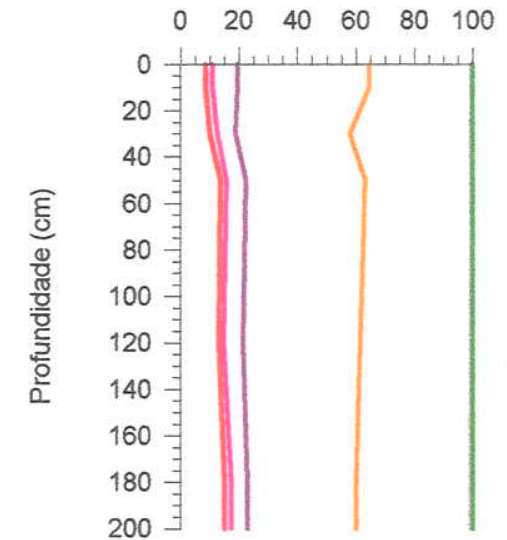

Fig. 3.5. Distribuição vertical das frações granulométricas ao longo da toposseqüência de Sumaré

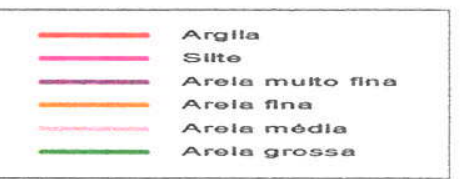


No topo, sua concentração é menor e alcança o máximo de $18,12 \%$, enquanto nas trincheiras situadas a partir da média vertente até o fundo do vale esses valores decrescem mais ainda. Como pode ser verificado na Fig. 3.5, o aumento da argila ocorre até a profundidade máxima de 1,0m; depois diminui e permanece uniforme, tendo os materiais um comportamento de B latossólicos.

\subsection{Toposseqüência de Umuarama}

Na toposseqüência de Umuarama não ocorre a fração areia grossa, contudo elevados teores de areia média estão presentes (Fig. 3.6 e Anexo 3).

A distribuição da areia média é um tanto anômala, isto é, a TR-I do topo é a que apresenta os valores mais baixos dessa fração, variando de $15,03 \%$ a $26,32 \%$, enquanto no topo do perfil da TR-IV, no final da vertente, seus teores são elevados, alcançando $45,51 \%$, diminuindo de forma significativa nos primeiros $40,0 \mathrm{~cm}$ de profundidade para, a partir daí, manter-se mais ou menos constante até a base do perfil. Na seqüência, aumenta de forma moderada do topo para o fundo da vertente.

Na TR-III, no final da seqüência, os teores de areia média sofrem modificações acentuadas em suas concentrações, ocasionadas pela deposição de um pequeno pacote coluvial. Essas oscilações de valores acontecem próximo da superfície, até $85,0 \mathrm{~cm}$ de profundidade, estando relacionadas às diferentes camadas de material coluvial, originadas da própria vertente. Quando o colúvio é ultrapassado, a distribuição granulométrica assume as características comuns apresentadas pelos materiais pedológicos da área.

A fração areia fina é a que predomina nas formações superficiais de Umuarama. Sua distribuição varia de forma pouco significativa tanto no perfil como ao longo da vertente. A distribuição no perfil torna-se truncada na TR-III, pelos motivos explicados anteriormente.

A distribuição da areia muito fina ocorre de modo inverso ao apresentado pela areia fina, uma vez que esta fração diminui de forma moderada ao longo da seqüência. Seus valores mais altos estão no terço superior da vertente, representados pelas TR-I e II, que alcançam $20,65 \%$, enquanto no fundo da vertente atingem o máximo de $12,66 \%$, 
exceto as concentrações encontradas nas camadas de colúvios, com $17,05 \%$, mesmo assim inferiores aos do topo.

Em geral, o valor de silte é o mais alto de todas as áreas estudadas, exceto para as amostras de rocha alterada da toposseqüência do sítio Três Leões. A distribuição do silte é semelhante à da areia muito fina.

O comportamento da argila ao longo da vertente lembra o da toposseqüência de Sumaré, isto é, suas concentrações mais elevadas encontram-se no terço superior. Na TRI, os teores de argila atingem $20,22 \%$ na base do perfil; à medida que se desce na vertente, ocorre uma redução com a diminuição gradual desses valores, até atingir $7,55 \%$, no volume superficial que está soterrado.

Comparando-se as três áreas estudadas, nota-se que na toposseqüência de Sumaré predominam as frações areia fina e areia média e a presença de areia grossa no topo da vertente e valores baixos de silte. Já na toposseqüência do sítio Três Leões, praticamente desaparece a fração areia média, com predominio das frações areia fina e muito fina e incremento nos valores de silte em direção a jusante. O que se destaca na toposseqüência de Umuarama é a maior participação da fração areia muito fina, em relação às demais.

A presença de frações mais grosseiras na toposseqüência de Sumaré e de areia muito fina e a maior quantidade de silte ocorrente na toposseqüência de Umuarama estão relacionados com a variação faciológica do arenito sotoposto, isto é, Sumaré estaria mais próxima da área fonte, enquanto na toposseqüência de Umuarama, por ser a mais distante da área fonte, os sedimentos encontram-se mais fraturados, tendo como conseqüência maior concentração de matriz mais fina (Fernandes, 1992). A pequena quantidade de areia grossa da toposseqüência do sítio Três Leões pode estar relacionada à posição topográfica onde foi realizado o estudo, isto é, num setor rebaixado, embutido no inteflúvio principal, constituindo-se num patamar secundário pobre nessa fração, ou mesmo relacionada ao material de origem, o Arenito Caiuá, onde essa fração ocorre de forma subordinada. 
TR-I

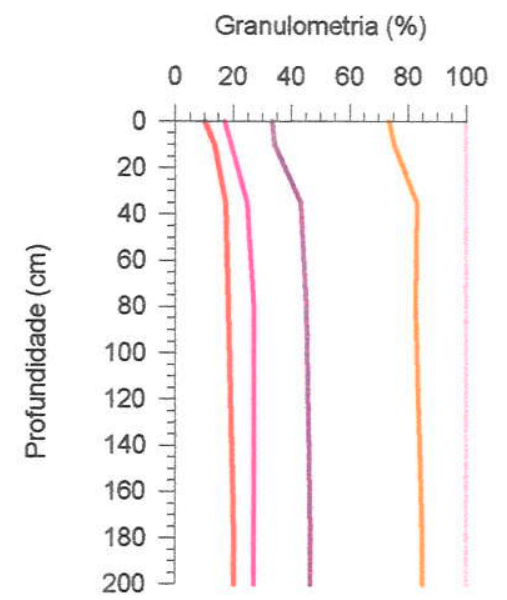

TR-II

Granulometria (\%)

$\begin{array}{llllll}0 & 20 & 40 & 60 & 80 & 100\end{array}$

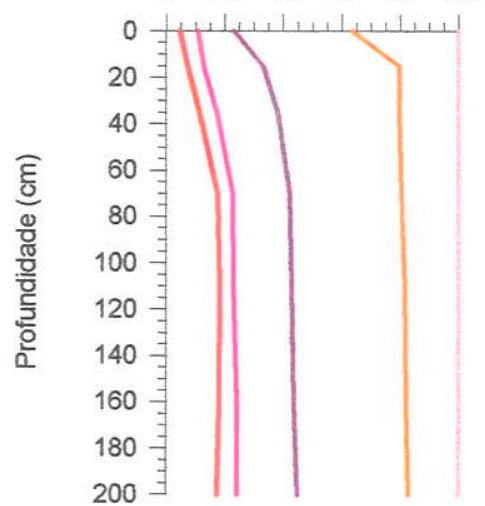

TR-IV

Granulometria (\%)

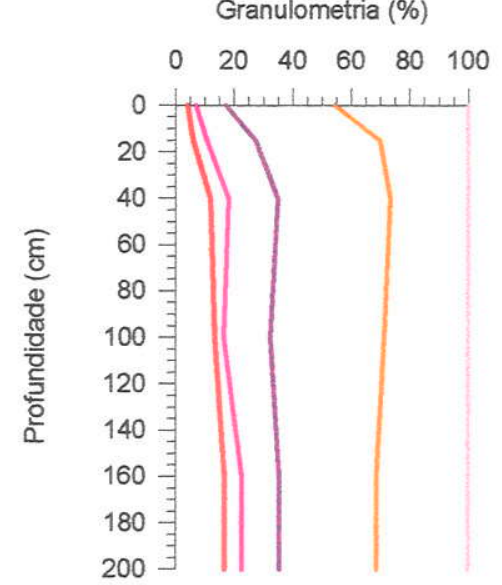

TR-III

Granulometria (\%) $\begin{array}{llllll}20 & 40 & 60 & 80 & 100\end{array}$

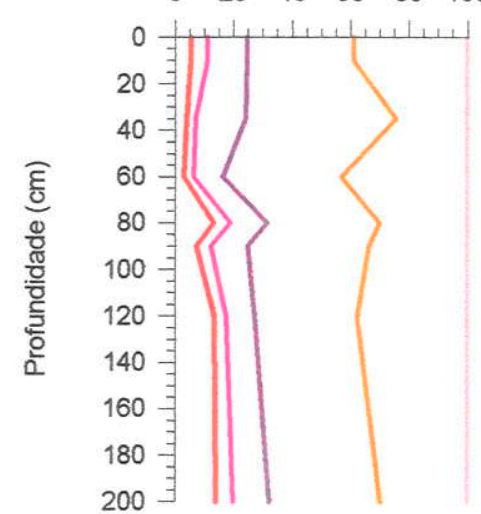

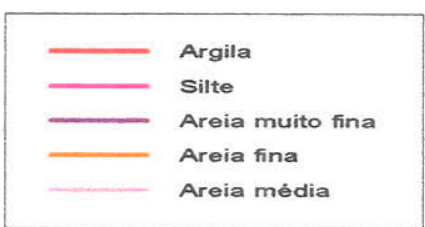

Fig. 3.6. Distribuição vertical das frações granulométricas ao longo da toposseqüência de Umuarama 


\subsection{Parâmetros estatísticos granulométricos de Folk \& Ward (1957)}

Os parâmetros estatísticos granulométricos (diâmetro médio, desvio padrão, assimetria e curtose), utilizados nos estudos da distribuição granulométrica dos sedimentos, tornaram-se componentes fundamentais de várias classificações de sedimentos. Embora existam diferentes métodos de cálculo, o que teve maior aceitação foi o concebido por Folk \& Ward (1957). A partir disso, ocorreu uma grande aceitação desses parâmetros, os quais foram utilizados pela maioria dos pesquisadores, além de uniformizar os dados em termos de apresentação de resultados (Giannini, 1987). Entretanto, junto com a aceitação dos critérios ora estabelecidos, surgiram também objeções quanto ao uso de maneira generalizada de tais parâmetros. Entre os críticos, destacam-se Chappell (1967) e Koldijk (1968), que alegam falta de sensibilidade dos métodos gráficos, principalmente nas partes caudais da distribuição granulométrica.

Recomenda-se, em razão de algumas objeções a esse método, que os resultados obtidos sejam comparados com outras técnicas de anáilises mais simples e mais seguras (Ponçano, 1986), como os diagramas triangulares de Folk, (1954); Shepard, (1954); Martins, (1967); Picard, (1971); Asseez, (1972).

Nesta pesquisa, procura-se fazer uma análise comparativa entre os dados granulométricos das formações superficiais, ocorrentes no noroeste do Paraná, e o Arenito Caiuá, utilizando-se para isso os parâmetros estatísticos granulométricos de Folk \& Ward (1957). O uso desses parâmetros visa estabelecer, se possível, alguma relação em termos de filiação, através da análise das frações grosseiras, da cobertura superficial e do arenito, uma vez que foi realizado um estudo detalhado de granulometria de ambos os materiais.

Para a interpretação das análises, separaram-se os resultados em duas partes, uma constituida de materiais finos, silte e argila, e a outra de grosseiros, maiores do que 0,053mm. Para Carvalho (1976), essa divisão tem por finalidade principal eliminar o efeito da fração fina sobre os resultados obtidos pelos parâmetros estatísticos granulométricos, quando são comparados aos resultados da fração grosseira do Arenito Caiuá.

O significado geológico dos resultados dos parâmetros estatísticos granulométricos não está totalmente esciarecido; contudo, podem auxiliar no conhecimento do ambiente de 
diminuem e passam a fazer parte de outra faixa, relacionada às curvas platicúrticas.

Os dados obtidos pelo método dos percentis de Folk \& Ward (1957), das formaçōes superficiais e do Arenito Caiuá, foram plotados em diagramas de dispersão, com a finalidade de facilitar a comparação entre os materiais. Comparando-se os resultados das relações das toposseqüências e do arenito, nota-se que os dados do Arenito Caiuá são mais espalhados, enquanto os das toposseqüências estão mais agrupados (Figuras 3.7 e 3.8).

Os valores do diâmetro médio $\mathrm{x}$ desvio padrão para as toposseqüências estão agrupados dentro do intervalo compreendido entre $2,0 \varnothing$ e $3,0 \varnothing$, com pequenas variações, isto é, um pouco mais grosseiro para a toposseqüência de Sumaré, enquanto que para o Arenito Caiuá os valores variam de forma mais ampla, de $1,0 \varnothing$ a $4,0 \varnothing$. Portanto, todos os valores encontrados para as toposseqüências estão inseridos nesse intervalo maior. Os valores mais espalhados, apresentados pelo Arenito Caiuá, podem estar relacionados à coleta de amostras em diferentes microambientes dentro da bacia, bem como a algumas de origem duvidosa, uma vez que existe uma semelhança muito grande entre as litologias que compõem o Grupo Bauru (Fulfaro \& Perinotto, 1996).

Os valores do desvio padrão evidenciam uma amplitude bem maior, principalmente para o arenito, indicando que este apresenta um baixo grau de seleção, quando comparado com os materiais das toposseqüências. Embora existam frações grosseiras nos materiais das formações superficiais, esses valores estâo mais agrupados, denotando um meihor grau de seleção para essas frações.

De modo semelhante ao desvio padrão, os dados de assimetria são espalhados, com valores positivos e negativos associados principalmente ao Arenito Caiuá. A variação de valores apresentados pela assimetria foi interpretada como sendo sensível ao ambiente deposicional, desde que os sedimentos não fossem afetados por processos diagenéticos (Folk \& Ward, 1957; Friedmann, 1961; Duane, 1964; Moiola \& Weiser, 1968). Como os dados ambientais são menos importantes neste trabalho, somos favoráveis à idéia de que os valores positivos e negativos encontrados nas toposseqüencias estejam mais relacionados com a migração de materiais finos a partir do topo para o sopé da vertente, com auxílio da circulação hídrica, que pode ser bastante eficiente nesses materiais (Cunha, 1996). 

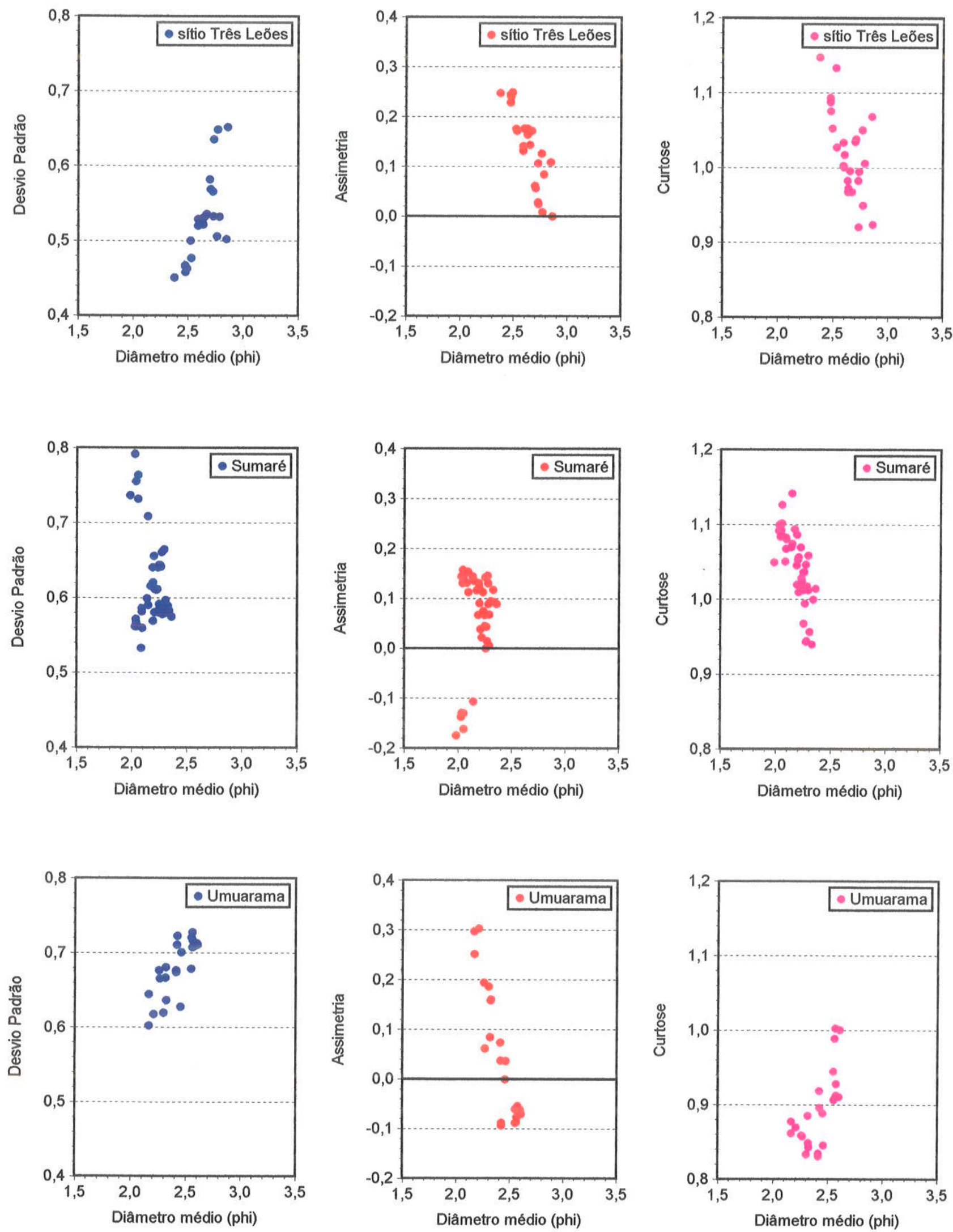

Fig. 3.7. Relação entre os parâmetros estatísticos granulométricos de Folk \& Ward (1957): diâmetro médio $x$ desvio padrão, diâmetro médio $x$ assimetria e diâmetro médio $x$ curtose das frações tamanho areia das formações superficiais estudadas 

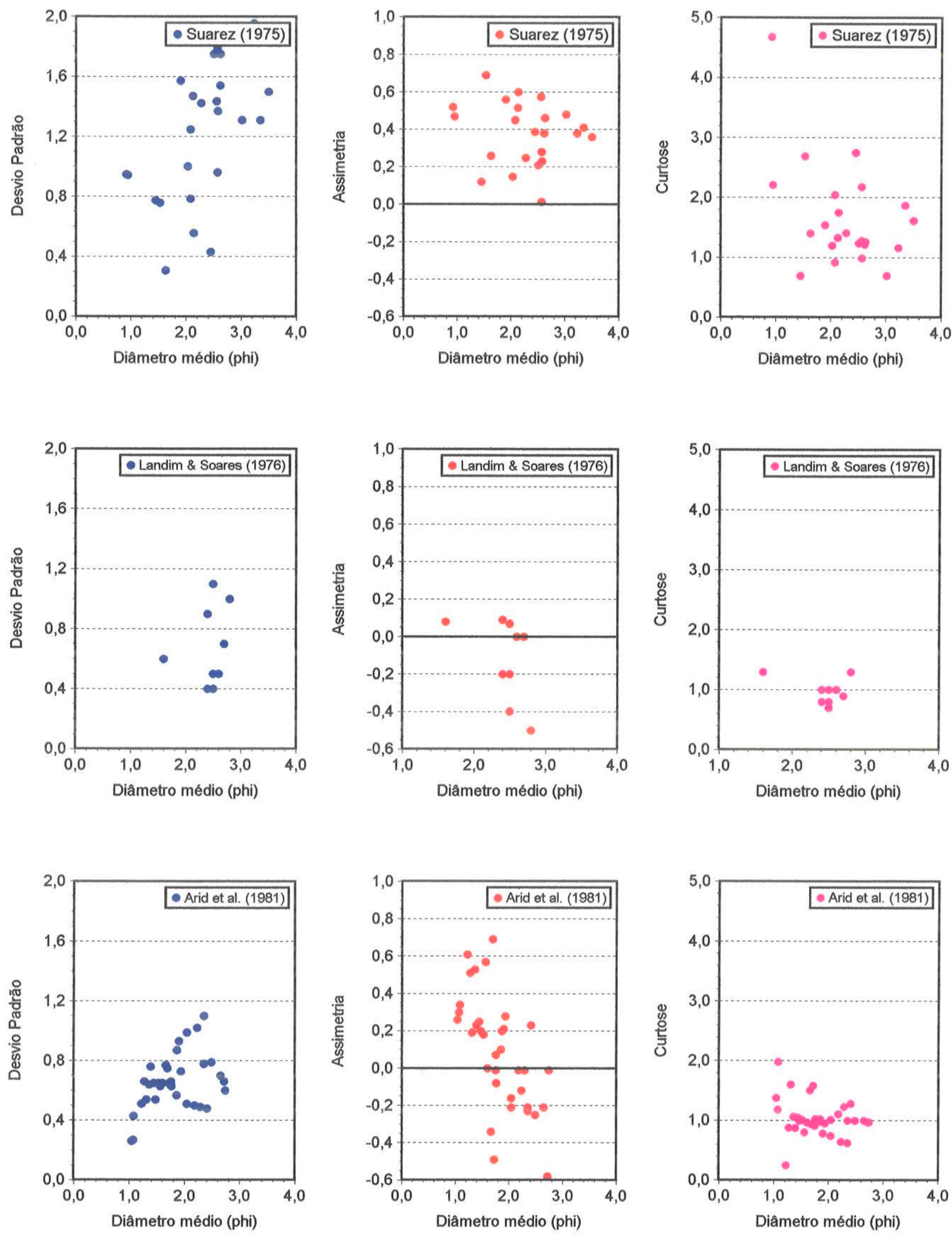

Fig. 3.8. Relação entre os parâmetros estatísticos de Folk \& Ward (1957): diâmetro x desvio padrão, diâmetro $x$ assimetria e diâmetro $x$ curtose obtidos a partir de dados coletados, no estado de São Paulo, para o Arenito Caiuá 
Cronan (1972) verificou que a mistura de populações de tamanhos diferentes favoreceria as mudanças de valores apresentados pela assimetria e curtose e que essas diferenças estavam relacionadas com a deposição de sedimentos cada vez mais finos, à medida que a velocidade do transporte diminuía.

Asseez (1972), ao fazer interpretações sobre ambientes deposicionais, concluiu que a dispersão de sedimentos reflete basicamente flutuações na competência do transporte, mistura de materiais com diferentes origens e, também, a coleta de amostras em diferentes microambientes.

Os valores da curtose estão dispersos no Arenito Caiuá e mais aglutinados nas formações superficiais. Os valores da curtose não foram ainda interpretados com clareza. No entanto, Ponçano (1986) considera que as distribuições leptocúrticas estejam relacionadas com remoção de uma fração de sedimentos e que as distribuições platicúrticas possam indicar mistura de sedimentos.

Convém ressaltar que os resultados obtidos pelos parâmetros estatísticos de Folk \& Ward (1957) não são conclusivos quanto à proveniência dos materiais das formações superficiais; no entanto, observa-se que todos os valores encontrados nas toposseqüências estão inseridos na faixa de valores apresentados pelo arenito sotoposto, sugerindo, portanto, uma provável filiação entre materiais que compõem a cobertura superficial e o Arenito Caiuá.

Dessa forma, concorda-se com Giannini (1987), que afirma que os parâmetros estatísticos são muito mais importantes na uniformização dos resultados do que na definição de origem de materiais. Por isso, esses dados devem sempre ser utlizados associados com outros mais confiáveis.

\subsection{A relação silte/argila}

Os valores médios da relação silte/argila aumentam do topo para o fundo da vertente nas toposseqüências do sítio Três Leões e de Umuarama, porém ocorre de modo inverso em Sumaré. Em geral, o valor da relação tende a decrescer com a profundidade, 
em razão do aumento da argila, nos volumes mais profundos (Anexo 3 ).

$\mathrm{Na}$ toposseqüência do sítio Três Leões são encontrados valores intermediários dessa relação, além de aumentarem em direção ao córrego. Na trincheira TR-1, o valor médio é de 0,19 , enquanto para a trincheira TR- II há um leve incremento e passa para 0,30. A TR-III, na média vertente, praticamente repete o valor da TR-II, com um aumento pouco significativo, atingindo 0,32 . Os valores da relação encontrados na TR- IV, no terço inferior, aumentam de modo brusco e atingem 0,51. A TR-V, no final da vertente, apresenta uma grande amplitude de valores em razão de as amostras coletadas próximo da base do perfil pertencerem à rocha alterada, que renova continuamente o conteúdo do silte, favorecendo desse modo um incremento significativo da relação, que atinge o valor médio de 0,65 . Portanto, o aumento brusco da relação verificado na TR-IV está relacionado com a presença do arenito alterado na base do perfil.

A toposseqüência de Sumaré apresenta os valores mais baixos dessa relação. $\mathrm{Na}$ TR-I, do topo, o valor médio é de 0,22 e sofre uma redução para 0,16 nas TR-VII e TR-VIII. A TR-VI, situada entre as trincheiras VII e VIII, mostra um valor médio de 0,29. Esse acréscimo ocorre sempre que as amostras são coletadas na superficie do terreno, portanto com baixa concentração de argila, o que faz crescer o valor da relação, uma vez que os teores de silte se mantêm com pequenas variações na vertente. Esse fato é melhor observado na TR-II, quando o valor médio atinge 0,32 , sendo que as demais trincheiras, localizadas a jusante, mostram uma tendência de redução no valor da relação, como pode ser observado na TR-III e na TR-IV, com valores médios de 0,28 e 0,25, reduzindo-se para 0,19 na TR-V no sopé da vertente (Anexo 3).

A redução dos valores da relação silte/argila, verificada nas trincheiras do terço inferior da vertente, pode estar relacionada com perdas seletivas diferenciadas dos materiais mais finos em subsuperfície.

$\mathrm{Na}$ toposseqüência de Umuarama são encontrados os valores mais elevados da relação silte/argila, como pode ser verificado na TR-1, que alcança o valor médio de 0,46, e na TR-II, que atinge 0,55 , localizadas no topo e alta vertente respectivamente. A TR-IV e a TR-III, situadas no final da vertente, apresentam valores médios compreendidos entre 0,52 e 0,66, respectivamente. Entretanto, o maior valor médio apresentado pela TR-Ill deve ser considerado com ressalvas, uma vez que quatro amostras são do material coluvial 
acumulado no sopé da vertente. Apesar de esse material ser oriundo da própria vertente, há concentrações de frações tornando a distribuição granulométrica bastante irregular, o que altera o resultado final (Anexo 3 ).

Os valores da relação silte/argila confirmam os resultados das análises granulométricas, isto é, os valores mais baixos dessa relação são encontrados na toposseqüência de Sumaré, onde predominam as frações mais grosseiras, e os mais altos na toposseqüência de Umuarama, onde predominam os materiais finos, com exceção daqueles valores encontrados no final da toposseqüência do sítio Três Leões. Os dados dessa relação estão de acordo, portanto, com a variação faciológica do arenito sotoposto, que, segundo Jabur \& Santos (1984) e Fernandes (1992), tende a ficar mais rico nas frações mais finas, à medida que se distancia da área fonte.

\subsection{Análise morfoscópica}

Um dos objetivos desta pesquisa é estudar a origem dos materiais que compõem as formações superficiais, no noroeste do Paraná; em razão disso foi dada grande importância às características apresentadas pelos grãos detríticos de quartzo, principal componente do esqueleto, que formam esses materiais. Para Boulet (1974), o esqueleto é formado por minerais primários de diferentes espécies, por produtos amorfos ou orgânicos. É necessário, entretanto, que todos os constituintes tenham tamanho suficiente, para que possam ser identificados por microscópio ótico. Com esse intuito, foi realizada uma análise morfoscópica detalhada dos grãos detríticos do esqueleto, com auxílio de microscópio eletrônico de varredura, visando, principalmente, identificar grãos fragmentados, picotados, fissurados, dissolvidos, corroídos, bem como identificar a composição da película que os recobre.

Nas rochas clásticas, o mineral mais comumente encontrado é o quartzo. Isso se deve, em parte, à sua grande estabilidade química $e$, também, ao fato de estar presente na majoria das rochas existentes na crosta terrestre. Apesar de não ser o constituinte principal de todas as rochas, é, sem dúvida, mais abundante do que os feldspatos, biotita, muscovita, caulinita, ou qualquer outro mineral. Mesmo em sedimentos formados por 
grande quantidade de fragmentos, o quartzo é comumente o constituinte em maior proporção. Em decorrência disso, pode ser considerado como o principal constituinte das rochas sedimentares clásticas e, portanto, é considerado um mineral de fundamental importância para a determinação de proveniência de arenitos (Krynine, 1937; Bokman, 1952; Pettijohn, 1975; Suttner et al., 1981; Basu, 1985; Moral Cordona et al., 1996; Moral Cordona et al., 1997).

A análise morfoscópica dos grãos detríticos de quartzo foi empregada, embora haja restrições quanto ao seu uso, para se definir proveniência ou mesmo especificar a rocha parental, uma vez que detalhes da morfologia superficial dos grãos, como rugosidade e arredondamento, podem ser originados, modificados ou apagados, durante o transporte, por agentes químicos pós-deposição ou mesmo por processos pedogenéticos (Blatt, 1967; Waugh, 1970; Pittman, 1972; Nordstrom \& Margolis, 1972; Riezebos, 1974; Pettijohn, 1975; Fritsch, 1988). Entretanto, quando são realizadas análises criteriosas da morfoscopia de grãos detríticos a partir da rocha mãe, passando por todos os estágios de alteração até atingir os materiais que formam o solo, acredita-se que semelhanças ou diferenças acentuadas entre os grãos detríticos possam representar, de algum modo, significado genético na interpretação de filiação que, no presente caso, seria entre as formações superficiais e o Arenito Caiuá.

A areia foi separada em várias frações granulométricas. Para cada intervalo, foram montadas lâminas para a determinação do tamanho, arredondamento e esfericidade dos grãos de quartzo (Krumbien, 1941; Rittenhouse, 1943). As amostras foram coletadas nas trincheiras, a partir do Arenito Caiuá, tendo-se o cuidado de coletar amostras em todos os estágios de alteração da rocha, até atingir o solo, ao longo das toposseqüências.

Para análise ao microscópio petrográfico, foram contados 100 grãos de quartzo de cada classe granulométrica. Mesmo no Arenito Caiuá, foram determinados somente os grãos de quartzo, procurando-se, dessa forma, evitar incertezas quanto aos teores, uma vez que outros minerais, como os feldspatos e as micas, que estão presentes na rocha, tendem a desaparecer nos materiais pedológicos, à medida que os processos de alteração evoluem.

Observando-se a Fig. 3.9, fica claro que o grau de arredondamento descresce de forma acentuada das frações mais grosseiras (areia grossa e média) para as frações finas 
(areia fina e areia muito fina). O mesmo acontece com a esfericidade; apesar de predominarem as formas arredondadas com alta esfericidade, principalmente nas frações grosseiras, tal não ocorre com as frações areia fina e muito fina, podendo atingir $35 \%$ de grãos com média a baixa esfericidade. Isso é válido para todas as amostras das formações superficiais, inclusive para as amostras do Arenito Caiuá.

Cabe ressaltar que em todas as amostras analisadas a mudança de classe de arredondamento ocorre na maior parte das vezes no intevalo $2,5 \varnothing(0,177 \mathrm{~mm})$, com exceção da toposseqüência do sítio Três Leões, onde a mudança ocorre no intervalo $3,0 \varnothing$ $(0,125 \mathrm{~mm})$. Isto é, os grãos detritais que são arredondados com alta esfericidade estão compreendidos nas classes inferiores a 2,5Ø. Quando os valores ultrapassam $2,5 \varnothing$, os grãos são predominantemente subarredondados e subordinadamente subangulosos, com média a baixa esfericidade.

Nas toposseqüências de Sumaré e de Umuarama, apesar de ocorrerem gräos bem-arredondados com teores que podem ultrapassar $20 \%$ do total da lâmina, esses grãos tendem a desaparecer nas frações areia fina a muito fina.

A análise de amostras do Arenito Caiuá apresenta o mesmo comportamento dos materiais que compõem as formações superficiais, caracterizando, dessa forma, uma provável filiação entre os materiais.

A seguir, serão apresentadas as PRANCHAS $X$ e $X I$, com uma série de fotomicrografias, obtidas com auxílio do microscópio eletrônico de varredura, de grãos detríticos de algumas das fraçōes granulométricas que fazem parte das formações superficiais e do Arenito Caiuá. Para cada intervalo granulométrico analisado, apresentase também a feição morfológica que mais vezes se repetiu, ou que se julgou importante. Essas observações permitem que sejam revelados detalhes e complexidades não identificados com o microscópio petrográfico.

Os grãos de quartzo exibem superfícies com diferentes feições, que são responsáveis por importantes modificações na sua morfologia. Algumas dessas feições foram originadas durante o transporte eólico e são reconhecidas pelo desenvolvimento de fraturas e crenulações sobre os grãos detríticos, observadas principalmente no Arenito Caiuá. Outras, estão relacionadas a dissolução química, desenvolvendo diversas formas 
Toposseqüência do sítio Três Leões

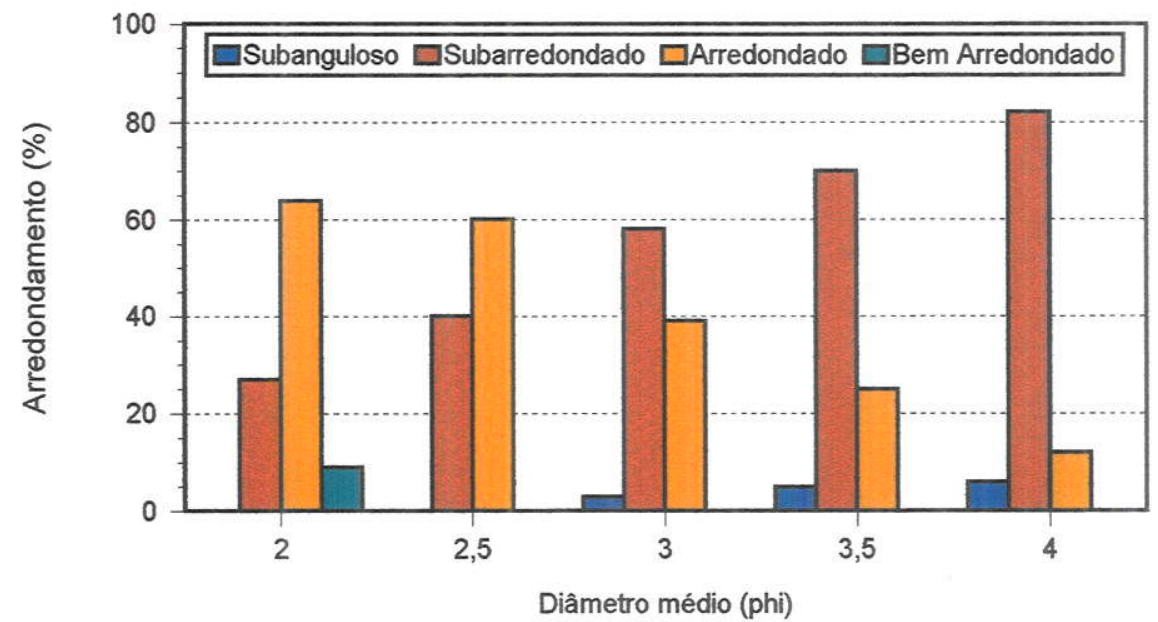

Toposseqüência de Umuarama

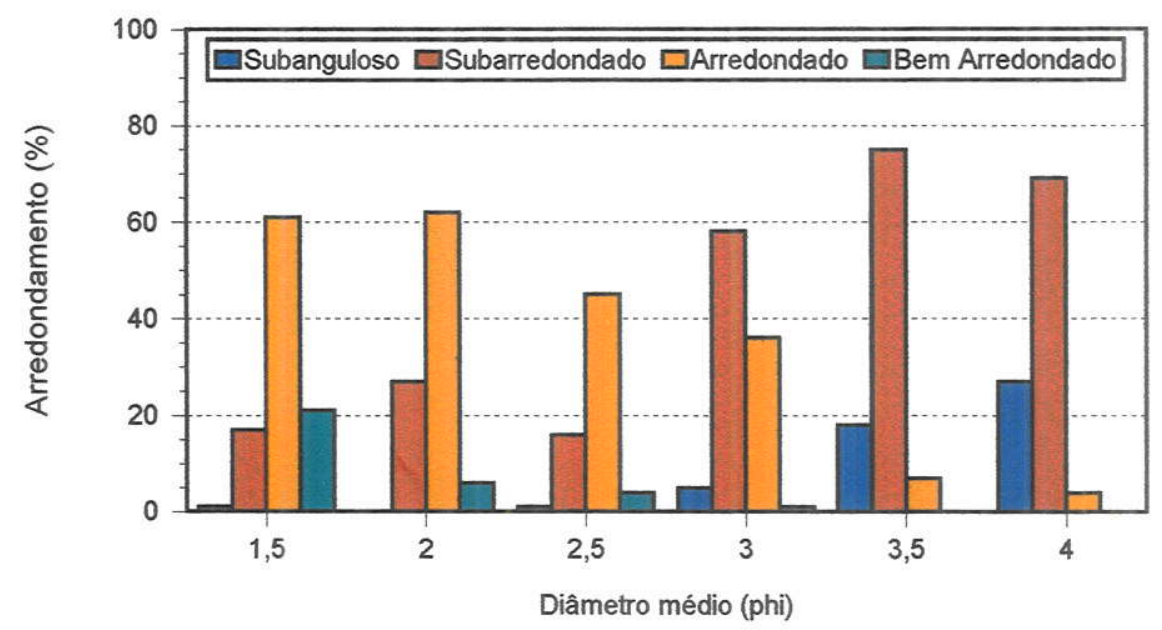

Toposseqüência de Sumaré

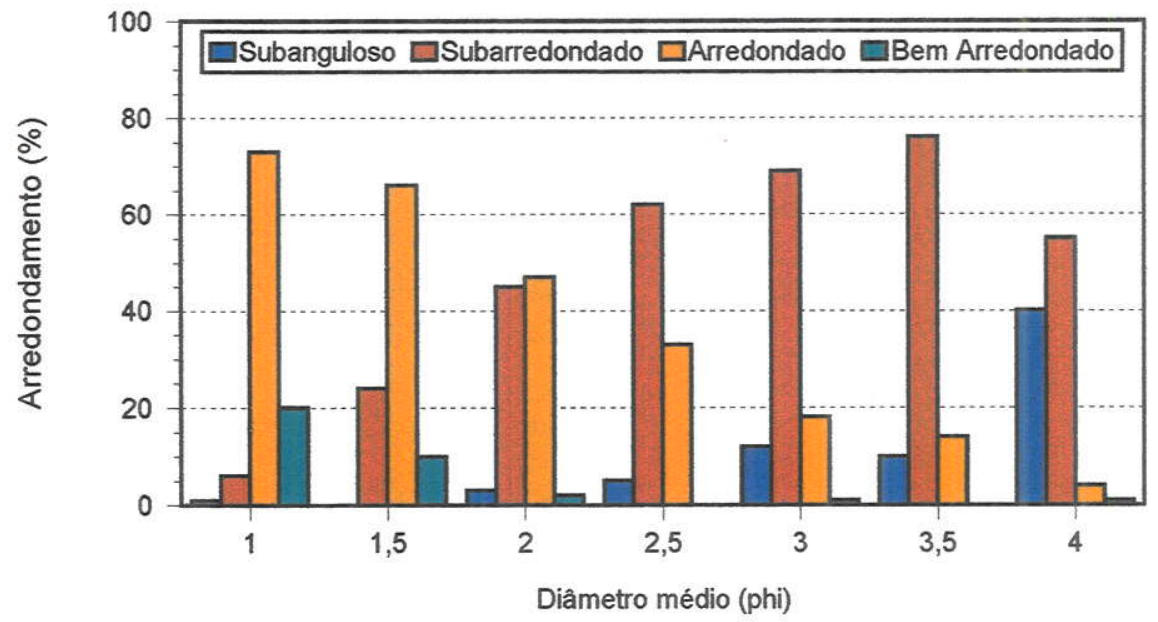

Arenito Caiuá

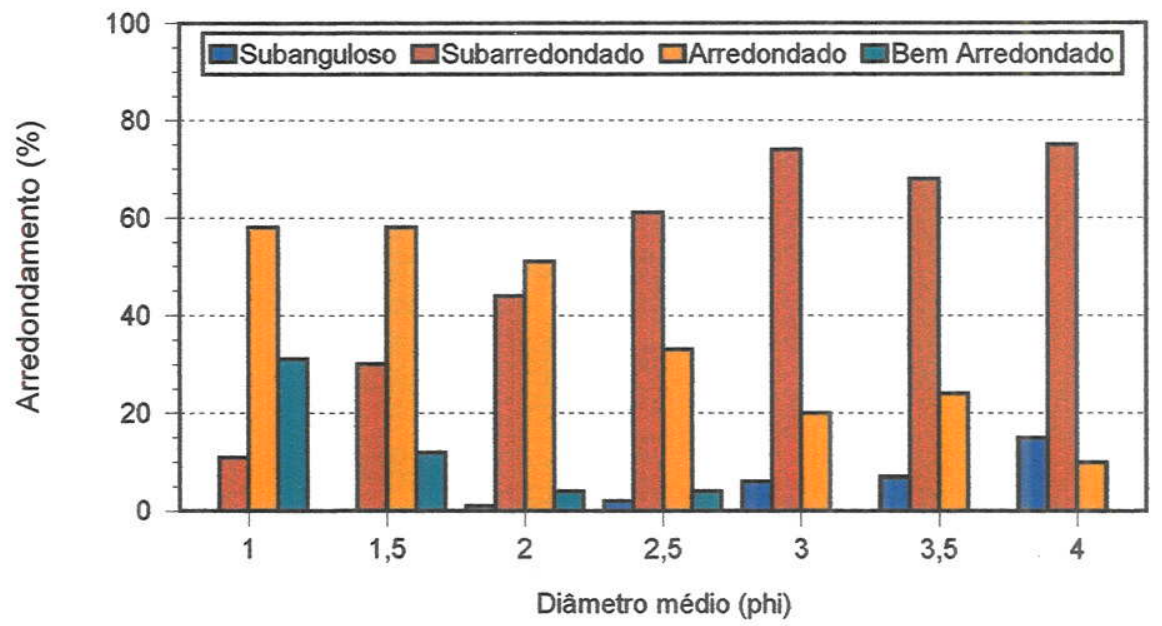

Fig. 3.9. Freqüência (\%) de arredondamento dos grãos detríticos de quartzo das diferentes frações granulométricas encontradas nas toposseqüências estudadas e do Arenito Caiuá 
PRANCHA X

\section{GRÃOS DETRITICOS DE QUARTZO DAS FORMAÇC̋ES SUPERFICIAIS}

Fotomicrografia 1: grãos detríticos de quartzo pertericentes à fração areia grossa $(0,50 \mathrm{~mm})$. Observar o grau elevado $\mathrm{de}$ arredondamento e esfericidade. Nessa fração é comum a presença de gräos fraturados e/ou com figuras de dissolução.

Microscópio eletrônico de varredura

Fotomicrografia 3: grãos detritícos de quartzo pertencentes à fração areia fina evidenciando um grau moderado de arredondamento e esfericidade.

Microscóplo eletrônico de varredura
Fotomicrografia 2: grão detrítico de quartzo exibindo cavidades geométricas na forma de triângulos (dente de serra) originadas pelos processos de dissolução química.

Microscópio eletrônico de varredura
Fotomicrografia 4: numerosas cavidades paratelas de tamanho variado com aspecto de tetraedros produzidas por dissolução química. O paratelismo das faces indica a presença de planos cristalográficos paralelos.

Microscópio eletrônico de varredura
Fotomicrogra fia 5: grãos detrítricos de quartzo pert tcentes à fração areia muito fina mostrando o baixo grau de arredondame to e esfericidade. Devido às dimensões reduzidas, dificilmente são identificadas as fissuras.

Microscópio eletrônico de varredura
Fotomicrografia 6: grão de quartzo praticamente seccionado pelos procesos de dissolução química. Grãos com esse aspecto geralmente são encontrados nas fraçōes mais finas.

Microscópio eletrônico de varredura 

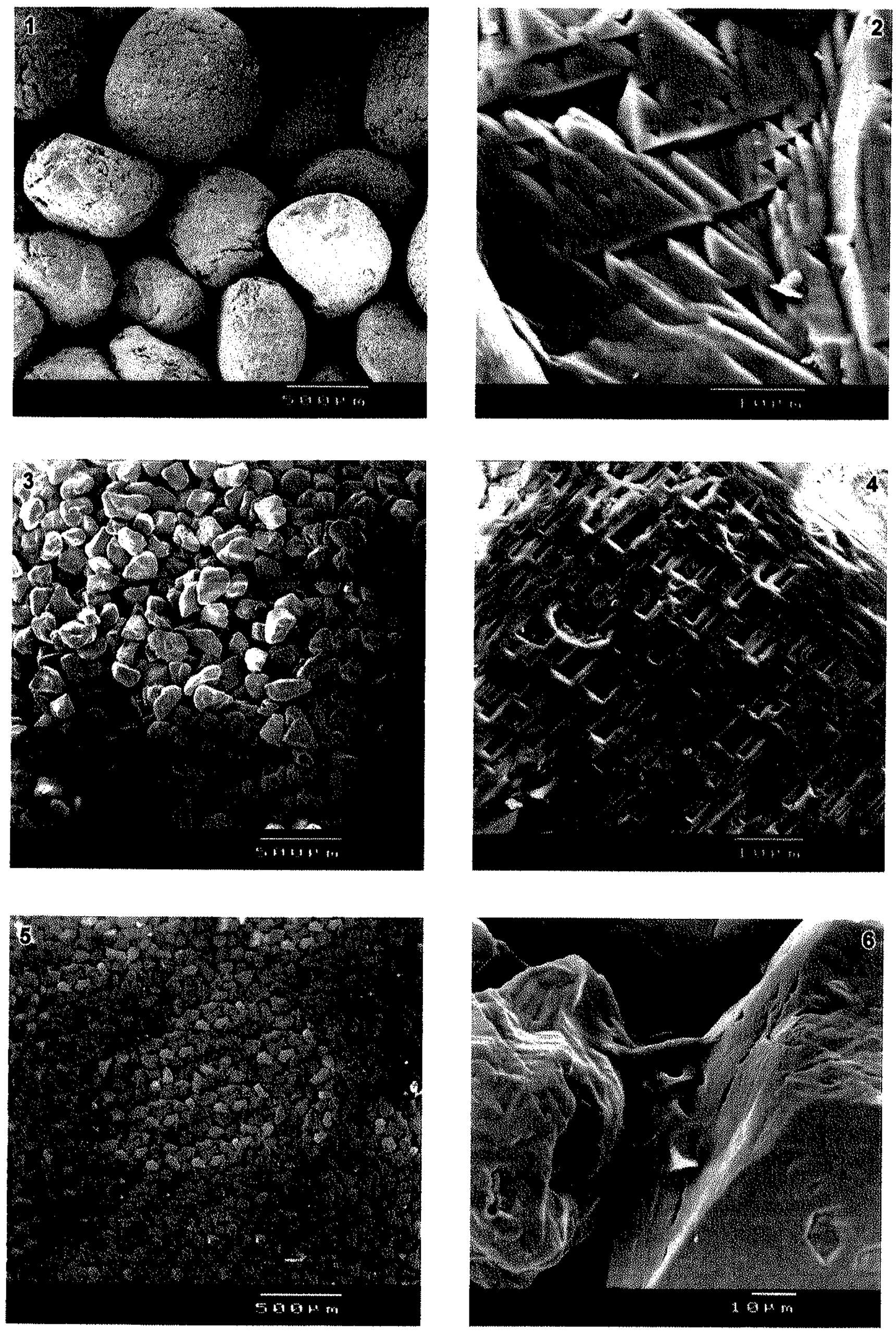
Fotomicrografia 1: grãos detríticos de quartzo pertencentes à fração areia grossa com elevado grau de arredondamento e esfericidade. No arenito são mais comuns as cavidades produzidas pelo impacto mecânico, originadas durante 0 transporte dos sedimentos.

Microscópio eletrônico de varredura
Fotomicrografia 2: detalhe de fissuras e cavidades produzidas por impacto mecânico durante o transporte eólico, dos grãos de quartzo $(Q)$. As cavidade maiores podem conter no seu interior materiais com a composição da caulinita (C).

Microscópio eletrônico de varredura
Fotomicrografia 3: grãos detríticos de quartzo pertencentes à fração areia fina. Verificar a redução do grau de arredondamento e esfericidade dessa fração. As formas assemelham-se com aquelas das formações superficiais. Microscópio eletrônico de varredura
Fotomicrografia 4: grãos de quartzo com numerosas fraturas com bordas cortantes e cavidades originadas durante o transporte eólico. Microscópio eletrônico de varredura
Fotomicrografia 5: grãos detríticos de quartzo da fração areia muito fina mostrando baixo grau de arredondamento e esfericidade semelhante aos das formações superficiais.

Microscópio eletrônico de varredura
Fotomicrografia 6: grão de quartzo com fratura conchoidal típica, originada durante o transporte eólico.

Microscópio eletrônico de varredura 

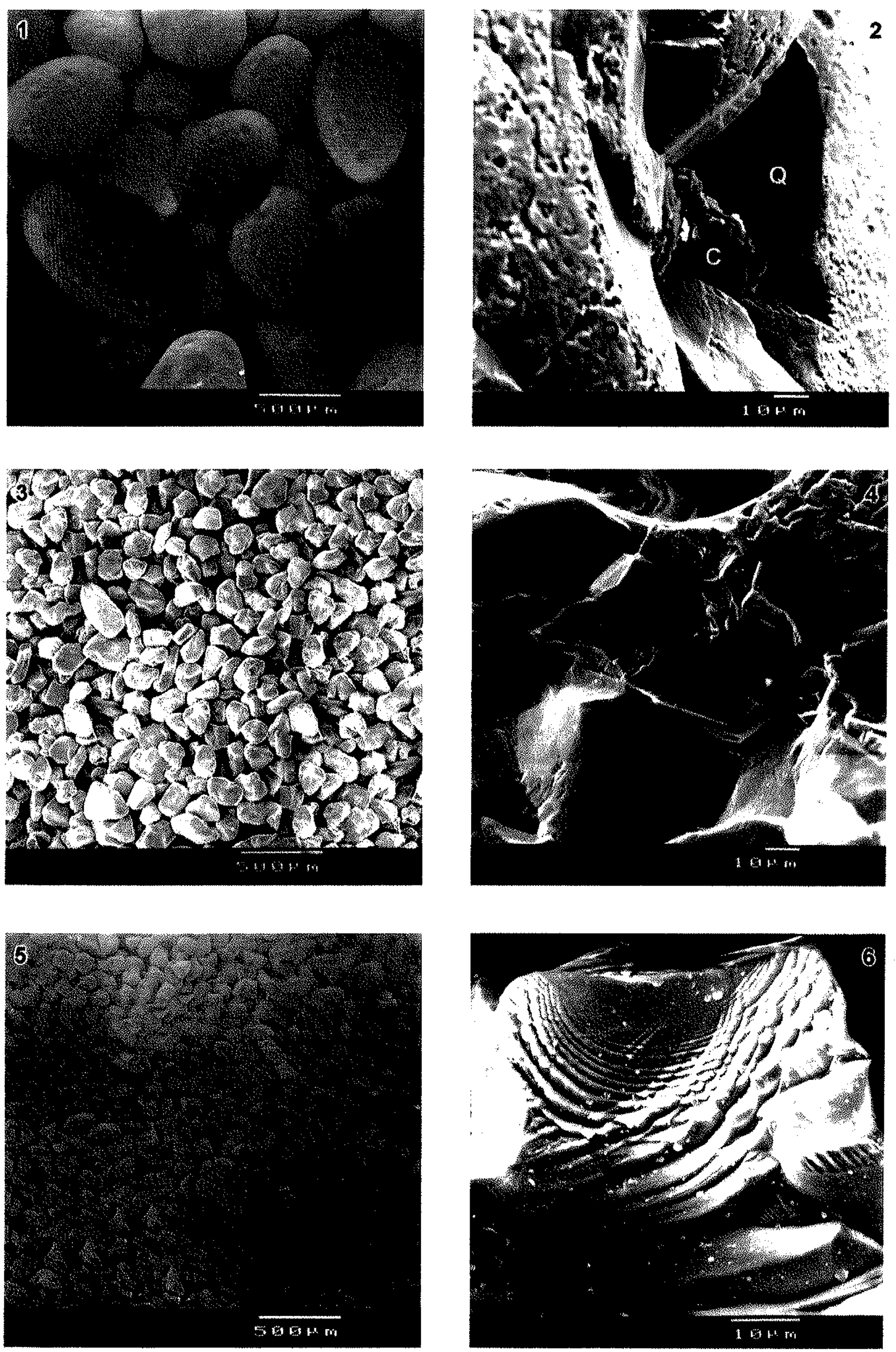
de figuras de corrosão, em decorrência dos processos de alteração que foram relatados como uma degradação hidromórfica associada a solos ferralíticos bem-drenados (Fritsch, 1988).

As análises da superfície dos grãos de quartzo, demostraram que existe uma semelhança, bastante significativa, entre os materiais que formam as formações superficiais e os sedimentos que compõem o Arenito Caiuá. Ambos os materiais são formados predominantemente pelas frações areia fina a muito fina, moderadas a bem selecionadas. Quanto a forma, os grãos mostram-se arredondados a bem arredondados com alto grau de esfericidade, principalmente nas frações grosseiras. Estas medidas tendem a diminuir com a redução do tamanho dos grãos.

\section{Caracterização mineralógica}

A composição mineralógica do Arenito Caiuá já foi descrita no Capítulo I, quando foram comentadas as características gerais da rocha fresca. Cabe, no entanto, ressaltar as características das espécies minerais que formam essa litologia, descrevendo os componentes encontrados na rocha original, passando pelos vários estágios evolutivos, desencadeados pelos processos de alteração supérgena. A abordagem será feita de forma única e não em separado ou por área, uma vez que a Formação Caiuá é caracterizada por apresentar grande homogeneidade litológica, da mesma forma que os produtos por ela originados. As espécies mineralógicas, encontradas nas toposseqüências sítio Três Leões, Sumaré e de Umuarama, são sempre as mesmas, mostrando semelhanças nas características que as identificam, variando apenas nas suas concentrações relativas e no grau de transformação, ocasionados pelos processos de alteração superficial. As pequenas diferenças de teores entre as espécies minerais indicam que o material de origem é o mesmo nas três áreas da pesquisa.

As espécies mineralógicas foram identificadas com auxilio da microscopia óptica convencional e do microscópio eletrônico de varredura (MEV). Os argilominerais foram determinados por difratometria de raios-x (lâminas orientadas), tomando-se a fração argila do volume $B$, coletada no topo, meia-vertente e sopé. Os diagramas de raios- $x$ das amostras 
natural, glicolada e calcinada obtidos para $2 \theta$, na faixa de $2^{\circ}$ a $32^{\circ}$, foram superpostos para facilitar a identificação e a interpretação dos argilominerais. Como auxílio a essa técnica foi empregada, também, espectroscopia de infravermelho.

Os difratogramas de raios- $x$ compreendidos entre $2^{\circ}$ e $90^{\circ}$ foram efetuados sobre o pó da amostra total, não orientada. Esse procedimento é importante porque permite a identificação praticamente de todas as espécies mineralógicas cuja concentração ultrapasse a $5 \%$ da amostra total (Fig. 3.10).

\subsection{Arenito Caiuá}

Entre os minerais leves, da fração grosseira $(>0,053 \mathrm{~mm})$, predomina o quartzo, e secundariamente destacam-se os feldspatos (microclínio e plagioclásio), calcedônia e mica. Entre os pesados aparecem os opacos (magnetita, hematita, ilmenita e leucoxênio), enquanto entre os transparentes ocorrem a estaurolita, a turmalina, o zircão, o rutilo e subordinadamente granada, cianita e monazita. Todos esses minerais estão agregados por cimento sílico-ferruginoso e carbonático ou ambos. A seguir serão descritas as características dos principais minerais que formam o Arenito Caiuá, encontrados nas toposseqüencias estudadas.

O quartzo é o constituinte principal do Arenito Caiuá, podendo alcançar concentrações superiores a $90 \%$. No microscópio óptico ocorre como grãos detriticos monocristalinos, límpidos, por vezes recobertos com uma fina película de óxido de ferro de cor vermelha; outras vezes apresenta-se fraturado, corroído, crenulado, apresentando dissoluções com forma de "golfos", que podem estar prenchidas por óxido-hidróxidos de ferro e argilominerais.

Os feldspatos são raros e estão bastante alterados e são encontrados somente em algumas lâminas delgadas do arenito alterado, mas facilmente identificados quando observados no MEV. Formam cristais subédricos, corroidos, geralmente com bordas serrithadas (PRANCHA V - Fotomicrografia 3). Nas amostras analisadas, sua concentração é baixa, porém seu teor pode ultrapassar a $15 \%$ na rocha desprovida de alteração. 

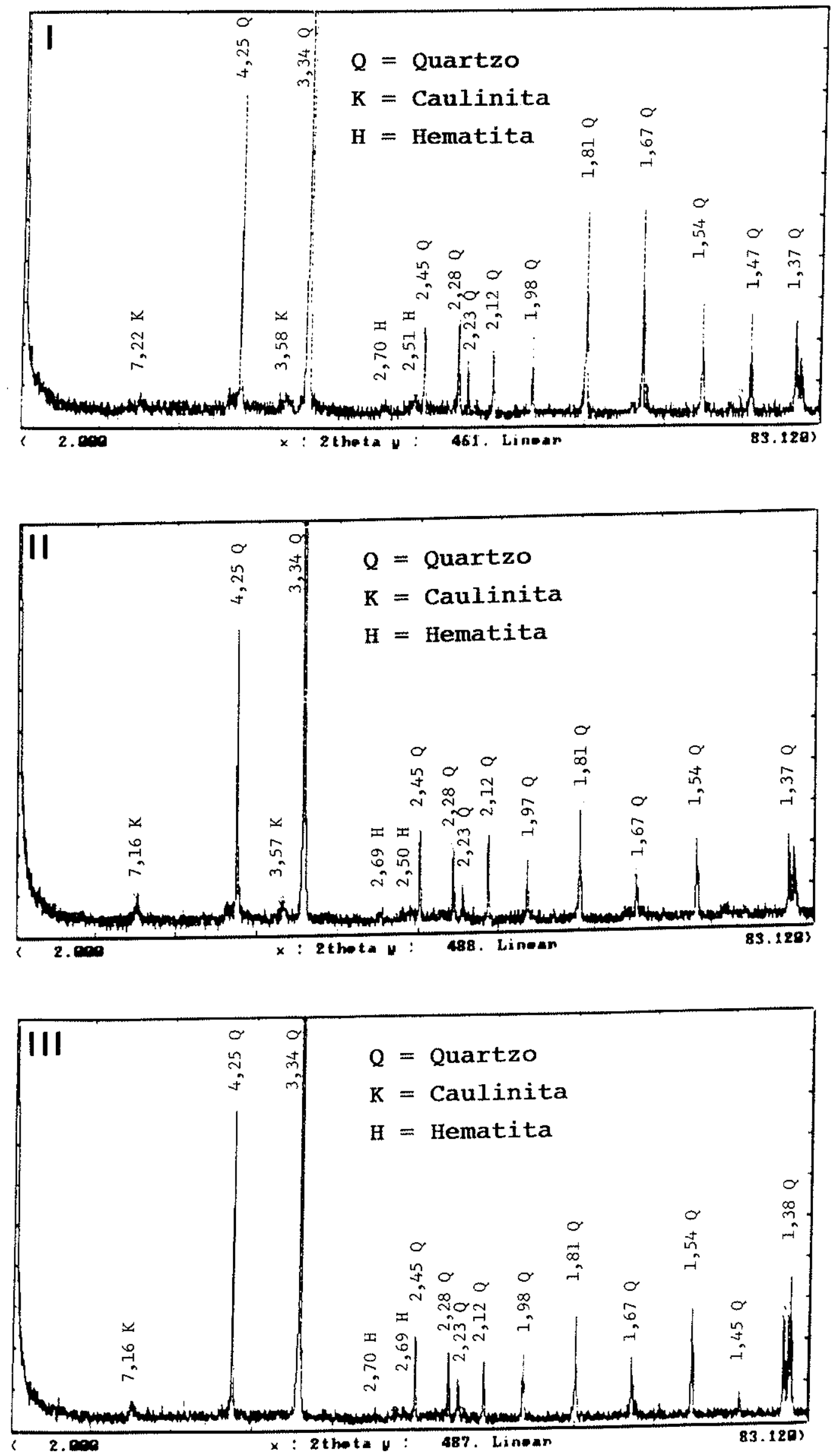

Fig. 3.10. Difratogramas de raios-x mostrando a mineralogia das formaçס̋es superficiais (I=topo, $\|=$ =meia-vertente e $\| \mid=$ =sopé da vertente 
A mica, com a composição da muscovita, é extremamente rara, e seus grãos são tabulares, às vezes angulares, arredondados a subarredondados, caracterizados pelo relevo baixo semelhante ao observado anteriormente na PRANCHA V - Fotomicrografia 4.

Entre os minerais pesados opacos, predominam a magnetita e/ou a maghemita, ocorrendo geralmente como pequenos cristais subangulares a arredondados, raramente bem-arredondados e angulares, com hábito cristalino, subédricos a anédricos, corroídos, formando pequenas reentrâncias nas bordas, desenvolvendo aspecto serrilhado. Sua origem é tida como uma contribuição das rochas basálticas sotopostas (Suarez, 1976; Soares et al., 1980; Fernandes, 1992).

A hematita predomina como cimento responsável pela cor avermelhada, mas também, em pequena quantidade, na forma de cristais opacos a translúcidos, que apresentam cor avermelhada. Sob microscopia óptica, geralmente aparece como grãos angulares a subarredondados e hábito cristalino, anédricos a subédricos, com bordas allteradas em tons avermelhados. Nos estágios mais avançados de alteração, a hematita pode impregnar as bordas de alguns grãos do esqueleto ou até mesmo preencher pequenas fissuras

A ilmenita, embora de difícil identificação devido ao seu baixo teor, ocorre geralmente como grãos subangulares a subarredondados anédricos a subédricos; outras vezes na forma de cimento, recobrindo os grãos de quartzo. Para Soares et al. (1980), a ilmenita ocorreria como uma fina película envolvendo os grãos de quartzo, e seria a responsável pelas cores vermelho-escura a arroxeada do arenito, sendo que a mesma seria derivada da magnetita por processos de alteração.

O mineral translúcido com aspecto de um material pulverulento, que ocorre na forma de pequenos pontos de cor esbranquiçada da rocha, foi identificado como leucoxênio, e sua origem estaria diretamente associada com a alteração da ilmenita.

Desse modo, a ilmenita e o leucoxênio seriam de origem secundária, formados a partir de compostos ferruginosos liberados de minerais pré-existentes, como a magnetita e a hematita. Assim, somente a magnetita e a hematita seriam herdadas das rochas fontes, que deram origem aos sedimentos responsáveis pela formação do Arenito Caiuá. 
Corroborando essa idéia, é conveniente ressaltar que, em análises realizadas através de difratometria de raios- $x$, em amostras de arenito alterado (agregado com cimento ferruginoso), encontrado no sopé da toposseqüência do sítio Três Leões, foram identificados somente picos pertencentes à hematita (Fig.3.10).

Apesar de espécies minerais como a mica e a calcedônia serem referidas na maior parte da bibliografia consultada sobre a composição mineralógica do Arenito Caiuá, elas são extremamente raras.

\subsection{Formações superficiais}

Embora as distâncias entre as toposseqüências estudadas sejam relativamente grandes (superiores a $80 \mathrm{~km}$ ), os solos apresentam aspectos bastante similares com relação à mineralogia, às propriedades físicas e principalmente no que diz respeito à textura. Entretanto, com base nos resultados das análises, obtidos por difratometria de raios-x $e$ espectroscopia de absorção de infravermelho sobre a composição do plasma argiloso, os solos estudados podem ser reunidos em dois grupos: solos com plasma caulinítico com hematita, correspondendo aos solos da regiäo de Sumaré e Umuarama, e solos com plasma predominantemente caulinitico e hematita combinado com pequenos teores de material com estrutura tipo $2: 1$, comuns na toposseqüência do sítio Três Leões.

Os minerais que constituem as formações superficiais são os mesmos que aqueles encontrados na Formação Caiuá. Dessa forma, todas as espécies de minerais ocorrentes no arenito são encontradas nos solos, além de haver uma semelhança na đistribuição das frações granulométricas, com exceção da argila, que tende a aumentar nos materiais pedológicos.

Os minerais grosseiros que formam o esqueleto do fundo matricial nas três áreas apresentam feições características de identificação semelhantes às encontradas na rocha sotoposta, diferenciando-se desta, apenas pela maior quantidade e composição do plasma.

O componente mineralógico principal dessas formações é o quartzo. Subordinadamente, aparecem os minerais pesados opacos e transparentes e raramente 
os feldspatos. Todos esses minerais estão envolvidos por um plasma argiloso de cor vermelha constituido por caulinita e hematita associada a pequenas concentrações de material com estrutura do tipo 2:1 nos interflúvios mais rebaixados, como aquele onde está localizada a toposseqüência do sítio Três Leões (Fig. 3.11). Enquanto nos latossolos encontrados sobre os interflúvios mais altos, como o da região de Paranavaí e de Umuarama predomina o plasma formado por caulinítica mais óxido de ferro (Fig. 3.12).

A identificação nos difratogramas de raios- $x$ de picos na região de 14A (amostra natural) associados e ausência de expansão significativa (amostra glicolada) levaram a identificar os argilominerais do tipo 2:1 como sendo, provavelmente, vermiculita com alumínio entrecamadas. Nesse caso, é possivel que o argilomineral presente seja realmente uma vermiculita com alumínio entrecamadas em razão da ocorrência de minerais micáceos na rocha original. Segundo Douglas (1989), In: Kämpf (1995) e Kämpf et al. (1995), a presença de vermiculita com hidróxido de alumínio entrecamadas ocorre nos solos quando no material de origem há a presença de micas. Portanto, a presença desses minerais se deve, provavelmente, à alteração de micas existentes no Arenito Caiuá e, também, às condições geoquímicas vigentes em solos ácidos, bastante evoluídos, que favorecem a existência de hidróxido de alumínio, que pode precipitar-se entre as camadas de vermiculita para originar camadas mistas, tornando esses minerais bastante estáveis nesse meio (Jackson, 1964).

A espectroscopia de infravermelho também confirma a predominância do plasma caulinítico com as bandas características a $3.697 \mathrm{~cm}^{-1} \mathrm{e} 3.621 \mathrm{~cm}^{-1}$. Contudo, a inexistência da banda $3.669 \mathrm{~cm}^{-1}$ da caulinita é um sensivel indicador de sua baixa cristalinidade (Farmer \& Palmieri, 1975; Besoain, 1985). A gibbsita ocorre em proporções muito pequenas, dificultando sua identificação por difratometria de raios- $x$, embora sua presença seja confirmada pela espectroscopia de absorção de infravermelho, definida pela presença das bandas $3.527 \mathrm{~cm}^{-1}$ e $3.443 \mathrm{~cm}^{-1}$ (Fig. 3.13).

É comum a presença de minerais ferromagnéticos nas formações superficiais, geralmente identificados como magnetita. No entanto, maghemita também é um mineral ferromagnético, muito comum nos solos originados de rochas vulcânicas, podendo ser facilmente confundido com a magnetita (Costa, 1996). A maghemita, pode originar-se no ambiente pedogenético pela oxidação do ferro divalente presente na magnetita durante os 

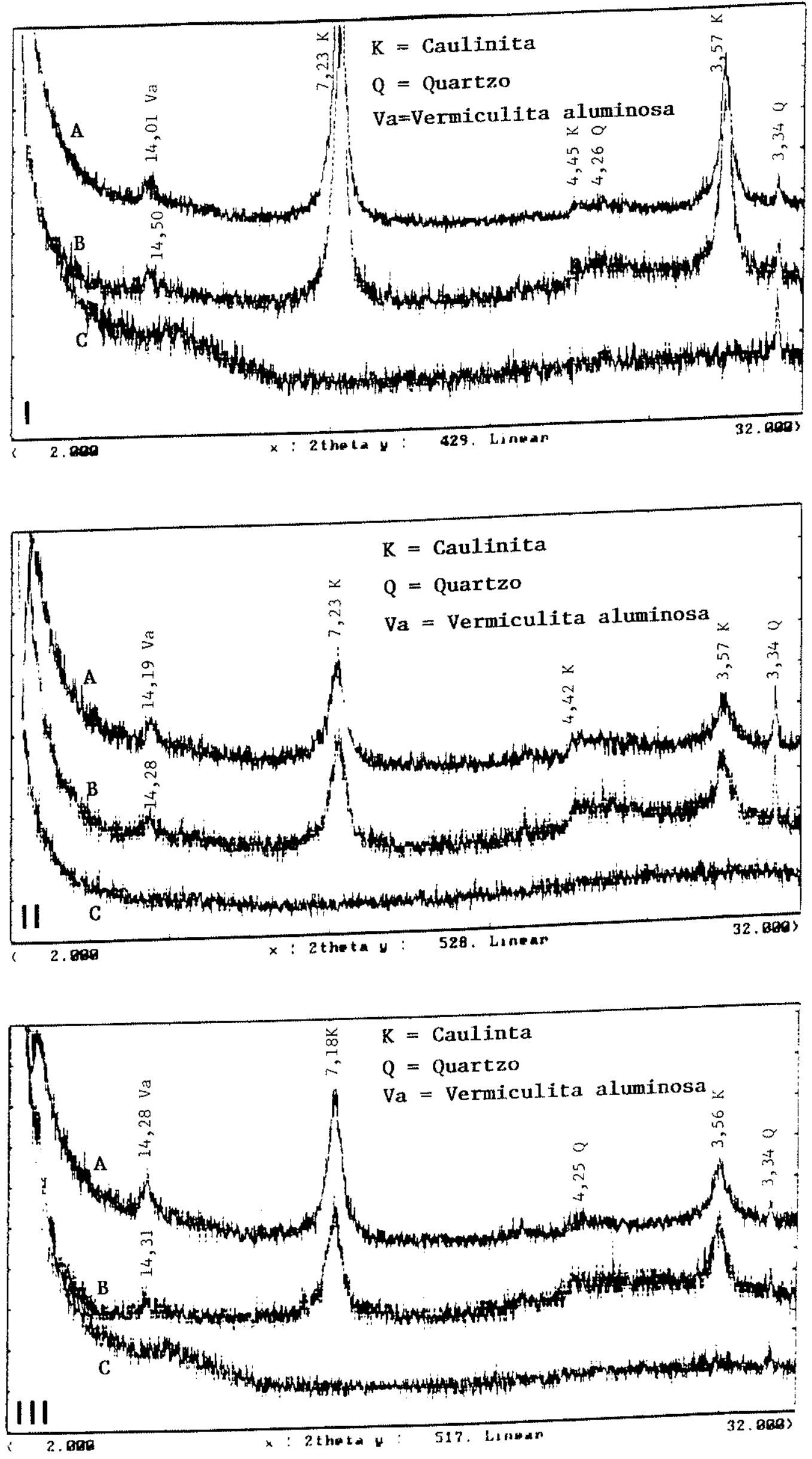

Fig. 3.11. Difratogramas de raios-x para a fração argila, do horizonte $B$, da toposseqüencia Tites $(A=$ natural, $B=$ glicolada, $C=$ calcinada; $\mid=$ topo, $\|=$ meia-vertente e $\| l=$ sopé da vertente 

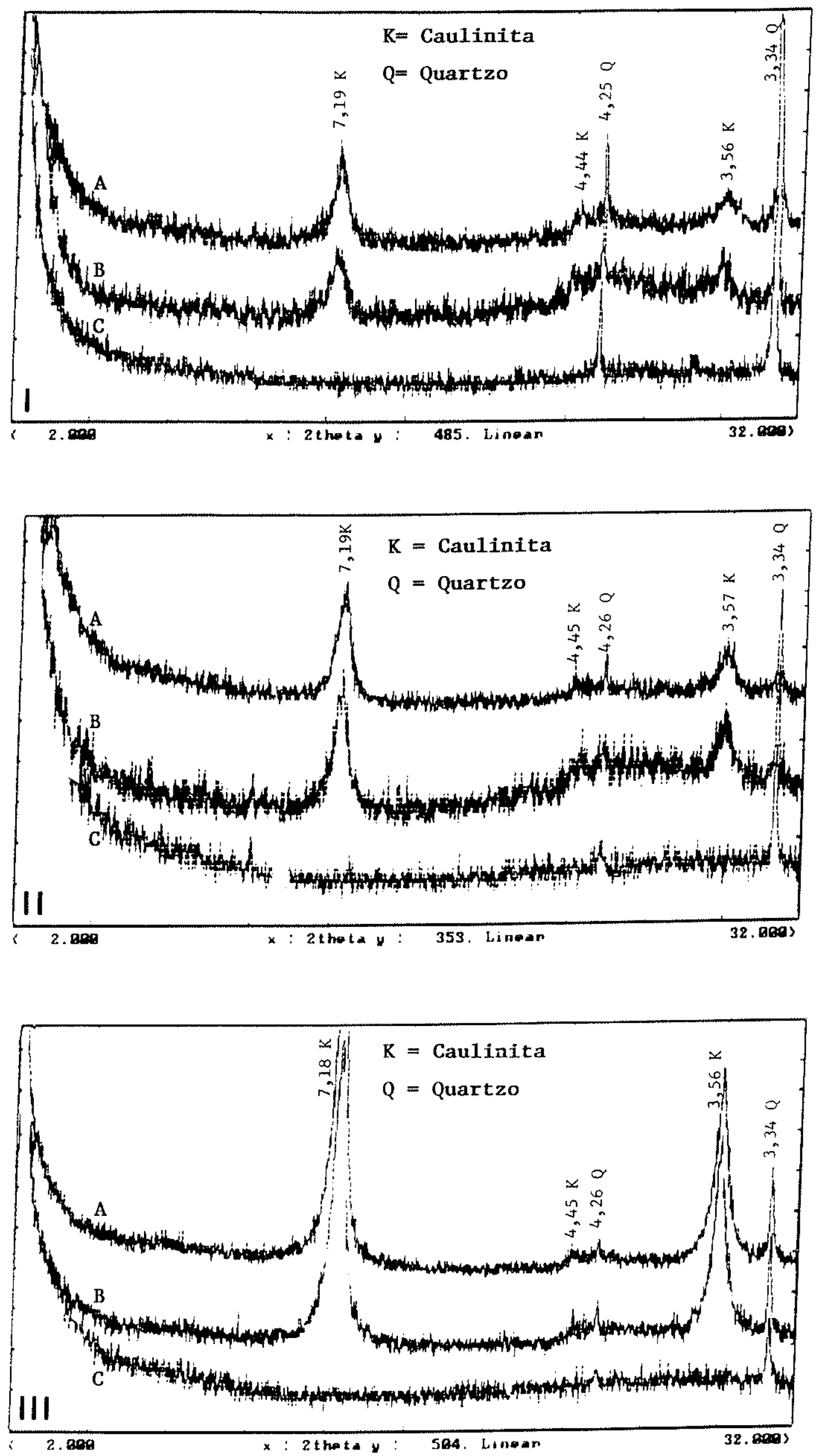

Fig. 3.12. Difratogramas de raios- $x$ para a fraçăo argila, do horizonte $B$, da toposseqüencia de Sumare $(A=$ natural, $B=$ glicolada, $C=$ calcinada; $\mid=$ topo, $\|=$ meia-vertente e $\| l=$ sopé da vertente 
Toposseqüência do sítio Três Leōes

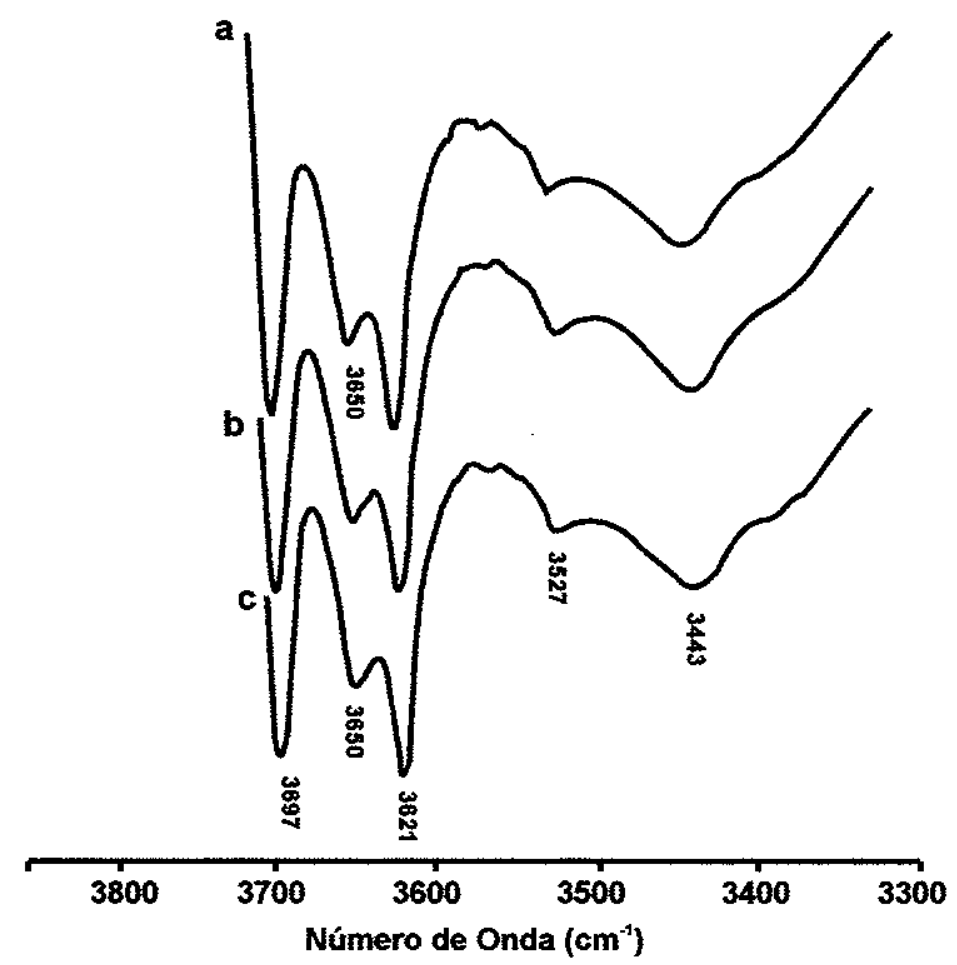

Toposseqüência de Sumaré

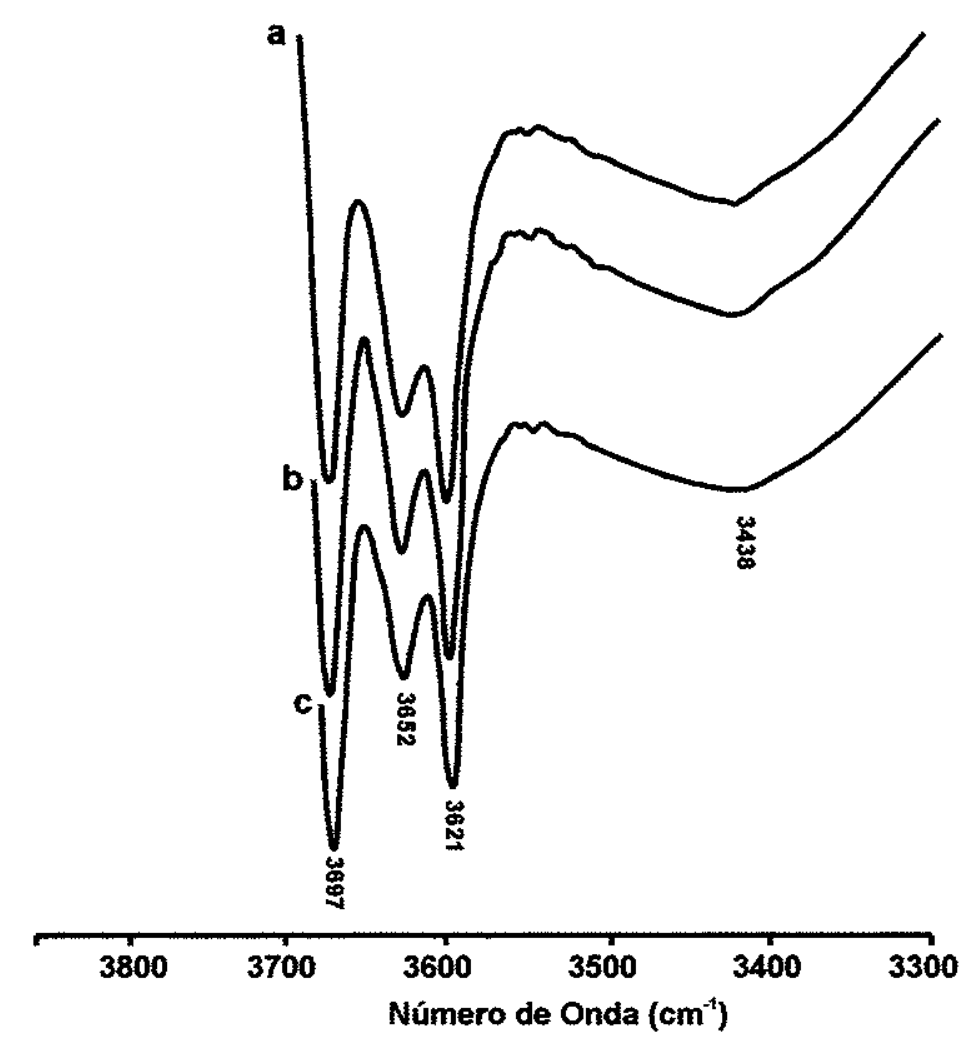

Fig. 3.13 Espectroscopia de infravermelho de amostras das toposseqüências do sítio Três Leões e de Sumaré (a=topo, $b=$ meia-vertente, $c=$ sopé da vertente) 
processos de alteração supérgena ou então de outros óxidos de ferro na presença da matéria orgânica (Schwertmann \& Taylor, 1989).

A caulinita, que está presente como o principal componente do plasma das formações superficiais nas três toposseqüências, provavelmente tenha sido originada por mecanismo de neoformação, a partir dos feldspatos presentes na rocha mãe, no ambiente pedogénetico ou então herdada do próprio arenito. Segundo Campos et al. (1982) e Fernandes et al. (1994), na fração fina do Arenito Caiuá e em profundidade há o predomínio de argilominerais do grupo das esmectitas, enquanto que mais próximo da superfície prevalecem amplamente argilominerais do grupo da caulinita. Rochas ricas em silicio e alumínio, e na ausência de outros cátions, submetidas às condições climáticas atuais, associadas a solos de boa drenagem, são altamente favoráveis ao desenvolvimento de caulinita (Millot, 1964; Grim, 1968; Brindley \& Brown, 1980).

A presença de gibbsita, no interior dos nódulos ferruginosos, pode estar relacionada a processos diferentes dos atuais, representando, dessa forma, relíquias de épocas passadas, preservadas pelas condições encontradas no interior dessas estruturas, que impediram trocas de soluções com o meio exterior.

\section{Minerais pesados das formações superficiais e do Arenito Caiuá}

A identificação e a análise dos teores de ocorrência dos minerais pesados, além de sua maturidade textural, têm por objetivo estabelecer correlações entre os estudos realizados nas toposseqüências localizadas em Cianorte, Paranavaí e Umuarama, bem como no material de origem, o arenito. O Arenito Caiuá alterado aparece somente no final da toposseqüência do sítio Três Leões, contribuindo, portanto, com poucas amostras para o estudo dos minerais pesados. Para aumentar o grau de confiabilidade dos dados dessas espécies encontradas no arenito, foram então coletadas amostras na toposeqüência São José, situada também em Umuarama e estudada por Cunha (1996). Esta difere das outras analisadas pela presença de solos rasos (iitólicos), o que permitiu a coleta de amostras do arenito alterado na base de todas as trincheiras. 
Para o estudo dos minerais pesados, foram coletadas amostras das formações superficiais nos diferentes volumes dos perfis das trincheiras das toposseqüencias. $\mathrm{Na}$ escolha das amostras que seriam analisadas, foram levadas em consideração a posição e a representatividade de cada volume, bem como sua continuidade lateral ao longo da vertente.

Optou-se, nesse estudo, pela fração areia muito fina para ser analisada, devido à sua melhor representatividade, em todas as amostras analisadas e, também, porque essa foi a fração que maior concentração apresentou de minerais pesados em relação aos outros intervalos amostrados.

\subsection{Assembléia de minerais pesados das formações superficiais}

A assembléia dos minerais pesados das formações superficiais que se desenvolvem no noroeste do Paraná mostra uma pequena diversidade mineralógica, onde se destacam os opacos, a estaurolita, o rutilo, a turmalina e o zircão como principais (Anexo 5). Secundariamente, ocorrendo como traços, temos granada, cianita e dumortierita. Os minerais pesados opacos se destacam entre os demais, na maior parte das amostras, podendo atingir até $90 \%$ do total da lâmina, constituídos basicamente por magnetita, hematita, ilmenita e leucoxênio.

Os graus de arredondamento e esfericidade foram determinados com auxílio de tabelas comparativas e classificados conforme sugestão de Krumbien (1941) e Rittenhouse (1943), como: angulosos, subangulosos, subarredondados, arredondados $e$ bemarredondados. A seguir serão descritas as principais características dos minerais pesados:

opacos: a magnetita, a ilmenita, a limonita e o leucoxênio são os minerais mais comuns, formando a maior parte da fração pesada, e podem chegar a $90 \%$ do total. Ao microscópio, ocorrem como grãos arredondados a subarredondados, estando presentes tanto nos materiais das formações superficiais como no Arenito Caiuá. As características descritivas dessas espécies encontram-se no item 3.1;

estaurolita: mineral de ocorrência abundante, com porcentagem variando de $3 \%$ a $55 \%$. 
Ocorre como grãos irregulares, pleocróicos, nas cores amarelada até amarelo-avermelhada e alongamento positivo. Ao microscópio, a maioria dos grãos apresentam-se subarredondados, arrendondados e, secundariamente, subangulosos, sem macla, com fratura subconchoidal característica, sendo comum a ocorrência de grãos com o aspecto de "queijo suiço", graças à existência de pequenas inclusões. As cores de interferência, em tons fortes e constantes, facilitam sua identificação;

rutilo: mineral pouco comum, variando em torno de $4 \%$ nas amostras estudadas. Ao microscópio, o rutilo aparece como grãos angulosos, com arestas subarredondadas $e_{\text {, }}$ subordinadamente, bem-arredondados, sem macla, quase opacos de cor geralmente avermelhada. Também ocorre com hábito prismático ou irregular e relevo alto. Em alguns grãos, são visiveis pequenas estrias segundo o alongamento;

turmalina: mineral bastante comum, com porcentagens que variam de $17 \%$ a $42 \%$. Os grãos apresentam-se com propriedades ópticas normais, facilmente identificáveis pelo seu pleocroísmo intenso, que varia de marrom-claro a marrom-escuro, às vezes em tons azulesverdeado e, raramente, azulado, arredondados a bem-arredondados, exibindo formas com alto grau de esfericidade, porém raramente prismáticas. Alguns grãos apresentam pequenas inclusões;

zircão: mineral abundante nas áreas de estudo com percentuais que variam de $18 \%$ a $54 \%$. Ao microscópio, ocorre como grãos arredondados, ovóides e prismáticos, terminados ou não em pirâmides com bordas arredondadas, relevo alto, límpidos ou com pequenas inclusões, pleocroísmo fraco em tons amarelado a incolor. Freqüentemente, os grãos aparecem com impregnações de óxido de ferro, o que dificulta sua identificação, pois assemelha-se, nesses casos, ao rutilo. No entanto, a distinção é facilitada ao se cruzar os nícois o rutilo matém a mesma cor;

granada: é um mineral raro; foi encontrado somente em duas lâminas da toposseqüência de Umuarama, junto ao sopé da vertente. Ocorre como grãos de formas irregulares, incolores, isotrópicos, angulosos a subangulosos, relevo alto e fratura conchoidal a subconchoidal. Essas características tornam as granadas um mineral de fácil identificação;

cianita: semelhante à granada em termos de ocorrência, são minerais considerados traços associados com o arenito alterado. Carcaterizam-se pelo hábito tabular, clivagem retangular 
pouco nítida, cristais incolores, sem pleocroísmo, extinção obliqua;

dumortierita: mineral muito raro, aparece somente no Arenito Caiuá alterado da toposseqüência do sítio Três Leões. O cristal apresenta forma de prisma curto com bordas arredondadas, clivagem proeminente, pleocroísmo forte variando desde incolor, prateado, até um azul intenso, extição reta. Junto às clivagens ocorrem impregnações de óxido de ferro.

\subsection{Distribuição dos minerais pesados das formações superficiais}

Após a identificação e a contagem dos grãos, verificou-se a ocorrência dos mesmos minerais, sem variações significativas nos seus teores, entre os volumes de uma mesma trincheira. Assim, optou-se por fazer a soma dos teores de cada volume, com a finalidade de determinar o valor médio dos minerais encontrados por trincheira. Com o valor dessa média, construíram-se gráficos que mostram a distribuição dos minerais pesados por trincheira. Portanto, a análise a ser feita será por trincheiras de cada toposseqüência, exibindo seu conteúdo percentual e o grau de arredondamento (Fig. 3.14 e 3.15 respectivamente).

$\mathrm{Na}$ toposseqüência do sítio Três Leões, fica bem evidente uma notável modificação na distribuição da estaurolita na vertente; isto é, além de apresentar teores menores do que em Sumaré, o conteúdo desse mineral diminui do topo para o fundo do vale. Quanto ao arredondamento, a estaurolita ocorre na forma subarredondada a arredondada, independentemente do setor da vertente em que se encontre.

Ao contrário do que acontece com a distribuição da estaurolita, o rutilo apresenta um aumento, embora pequeno, de seus teores, à medida que se desce para o sopé da vertente. Esse fato chama a atenção, uma vez que os teores de rutilo na toposseqüência variam em torno de $4 \%$, enquanto que no terço inferior (TR-V) o mesmo atinge $16 \%$. Essa anomalia torna-se clara pelo fato de que em nenhuma outra amostra o rutilo ultrapassou $9 \%$. Essa discrepância pode também estar relacionada às características da amostra coletada junto ao arenito alterado. O rutilo ocorre na forma subarredondada, com exceção 
da TR-I, onde as formas subarredondada e arredondada se equivalem.

A turmalina mantém suas concentrações ao longo da vertente, com exceção da TR III, que apresenta um leve incremento. Quanto à forma, esse mineral apresenta os mais altos graus de arredondamento quando comparado aos demais minerais pesados, ocorrendo geralmente nas formas arredondada a bem-arredondada e, secundariamente subarredondada.

O zircão apresenta comportamento semelhante ao rutilo, aumentando suas concentrações à medida que se desce na vertente, porém de forma mais acentuada. $O$ crescimento de seus teores para jusante pode ser explicado da mesma maneira como foi salientado anteriormente para o rutilo, isto é, seus teores aumentam ao se aproximar do arenito alterado no sopé da vertente. A forma de seus grãos é geralmente arredondada; secundariamente, ocorrem formas subarredondada a bem-arredondada.

Na toposseqüência de Sumaré, afora o predomínio da estaurolita sobre os demais minerais pesados, todas as espécies mantêm seus teores com pequenas variações ao longo da vertente. Depois da estaurolita, o mineral mais comum é o zircão, com exceção da TR-1, onde a turmalina apresenta teores mais elevados.

O rutilo aparece como coadjuvante nessa toposseqüência, o que está de acordo com os dados de Fernandes (1992), que estudou os minerais pesados do Arenito Caiuá, onde o rutilo ocorre como mineral pesado secundário. A estaurolita apresenta-se predominantemente subarredondada a subangular e, mais raramente, arredondada, ao longo de toda a vertente.

Os demais minerais: rutilo, turmalina e zircão, tendem a aumentar levemente o seu grau de arredondamento em direção a jusante da vertente, principalmente quando são comparadas amostras do topo (TR-I) com as espécies descritas da média vertente (TR-II). No sopé (TR-V), a diferença no grau de arredondamento entre a estaurolita subarredondada e as demais espécies arredondadas fica mais acentuada quando se comparam o topo e o fundo do vale.

$\mathrm{Na}$ toposseqüência de Umuarama são encontradas as mesmas espécies de minerais pesados, e os seus teores assemelham-se aos da toposseqüência de Sumaré, com exceção do zircão, que ocorre com teores inferiores. A estaurolita e a turmalina são as 
espécies predominantes em toda a vertente. A estaurolita apresenta um pequeno aumento de concentração na direção de jusante, enquanto a turmalina mantém-se praticamente estável. O zircão, com menores teores, apresenta comportamento inverso ao da estaurolita, isto é, tende a diminuir em direção ao fundo do vale. O rutilo ocorre com teores extremamente reduzidos. Quanto ao arredondamento, nessa toposseqüência prevalecem as formas arredondadas das espécies minerais, com exceção da estaurolita, em que predominam a subarredondada $e$, secundariamente, a forma arredondada.

Na toposseqüência São José, o conteúdo da estaurolita é bastante baixo na TR-I e na TR-II, situadas no setor de montante sobre solos rasos, quando comparado com as outras trincheiras, porém com teores semelhantes aos encontrados no final da toposseqüência do sítio Três Leões. Na TR-III, no sopé da vertente, sobre solo podzólico, apresenta leve aumento. As características do mineral são mantidas, predominando as formas subarredondada e, subordinadamente, arredondada.

Quanto ao rutilo, apesar de haver um pequeno incremento com relação a outras toposseqüências, entre as trincheiras não há modificações significativas. As formas que prevalecem são a arredondada e, subordinadamente, a subarredondada.

A turmalina mantém seus teores na TR-I e na TR-II, enquanto na TR-III apresenta um pequeno incremento. Esse aumento pode estar relacionado à localização da trincheira, que nesse setor da vertente caracteriza-se por ser um local de acúmulo de material proveniente das áreas a montante. A forma arredondada dos grãos prevalece sobre as demais, ficando a subarredondada e a bem-arredondada em segundo plano.

O zircão é o mineral que ocorre em maiores proporções na toposseqüência, destacando-se a TR-II, onde atinge mais de $50 \%$ do total amostra. As formas mais comuns de ocorrência do zircão são, preferencialmente, arredondada e, secundariamente, subarredondada e bem-arredondada.

A toposseqüência São José difere das outras pelo seu baixo conteúdo de estaurolita. Os teores de estaurolita, no entanto, são semelhantes às concentrações do final da toposseqüência do sítio Três Leões (TR -V). Isso provavelmente ocorre pela presença do arenito alterado próximo da superfície.

De modo geral, na toposseqüência de Sumaré predomina a estaurolita, com 
valores constantes, em toda a vertente. A turmalina apresenta uma pequena redução em direção ao sopé, enquanto o zircão mostra o contrário, isto é, aumenta no mesmo sentido. Os teores de rutilo são extremamente baixos. Na toposseqüência do sitio Três Leões a estaurolita diminui em direção ao sopé, enquanto o zircão e o rutilo aumentam. A turmalina mostra-se constante em toda a seqüência. Em Umuarama a estaurolita e a turmalina predominam amplamente sobre as demais espécies de minerais, em toda a vertente. $A$ estaurolita aumenta em direção a jusante, ao passo que a turmalina pouco varia. $O$ zircão diminui consideravelmente suas concentrações e o rutilo praticamente desaparece em direção ao sopé. Na toposseqüência São José o zircão e a turmalina são as espécies minerais mais abundantes seguidas do rutilo, ao passo que a estaurolita diminui consideravelmente, mantendo contudo valores constantes na seqüência.

Neste estudo não foram comprovadas variações significativas no conteúdo dos minerais pesados, entre os materiais das formações superficiais e do Arenito Caiuá. Em geral, a estaurolita acumula-se relativamente e a sua quantidade é sempre maior nos latossolos ou nas posições mais altas das toposseqüências. O rutilo e de certa forma 0 zircão parece estarem associados a materiais mais jóvens próximo da rocha alterada, enquanto as concentrações de turmalina pouco variam independentemente do setor da vertente analisado.

A assembléia formada por estaurolita, rutilo, turmalina e zircão sugere alta maturidade mineralógica de ambos os materiais, além de não ocorrer concentração de nenhuma espécie mineral ao longo das toposseqüências. Isso também representa um argumento muito consistente quanto à origem das formações superficiais, sugerindo que elas tenham sido geradas pelos processos de alteração in situ diretamente do arenito sotoposto, confirmando desse modo a presença de coberturas residuais, na região noroeste do Paraná. 
Toposseqüência do sítio Três Leões

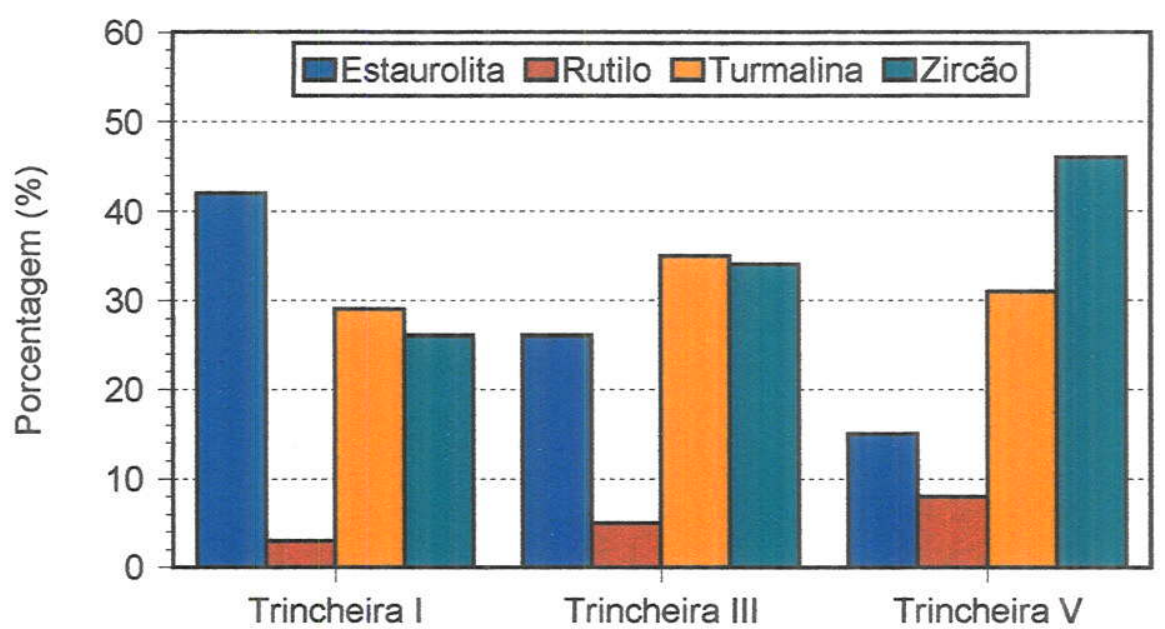

Toposseqüência de Umuarama

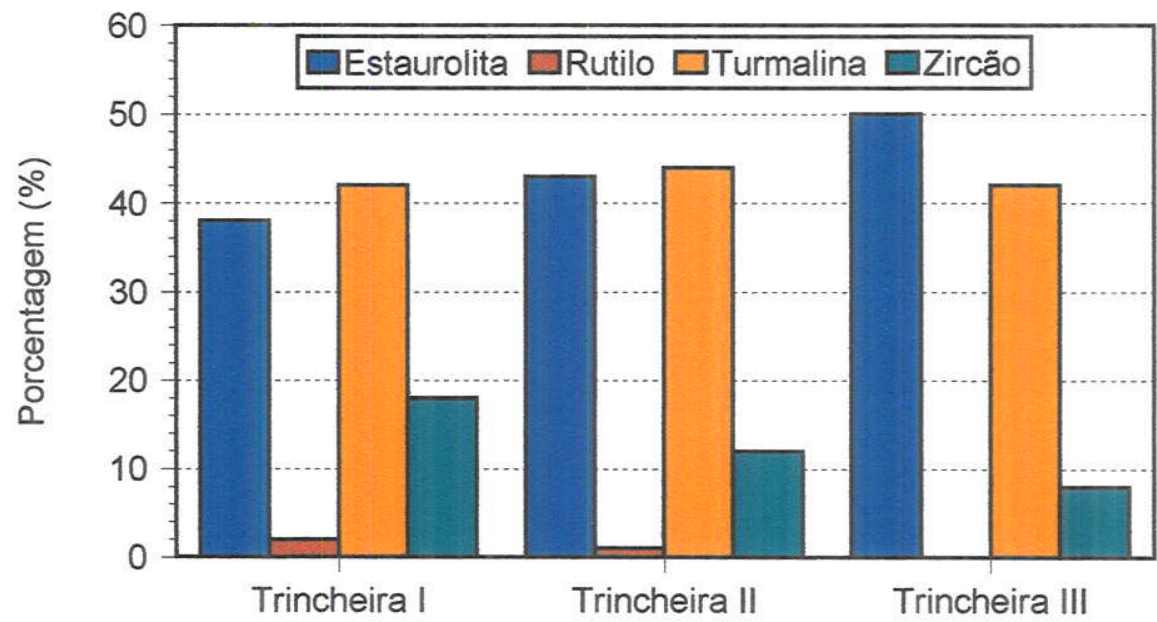

Toposseqüência de Sumaré

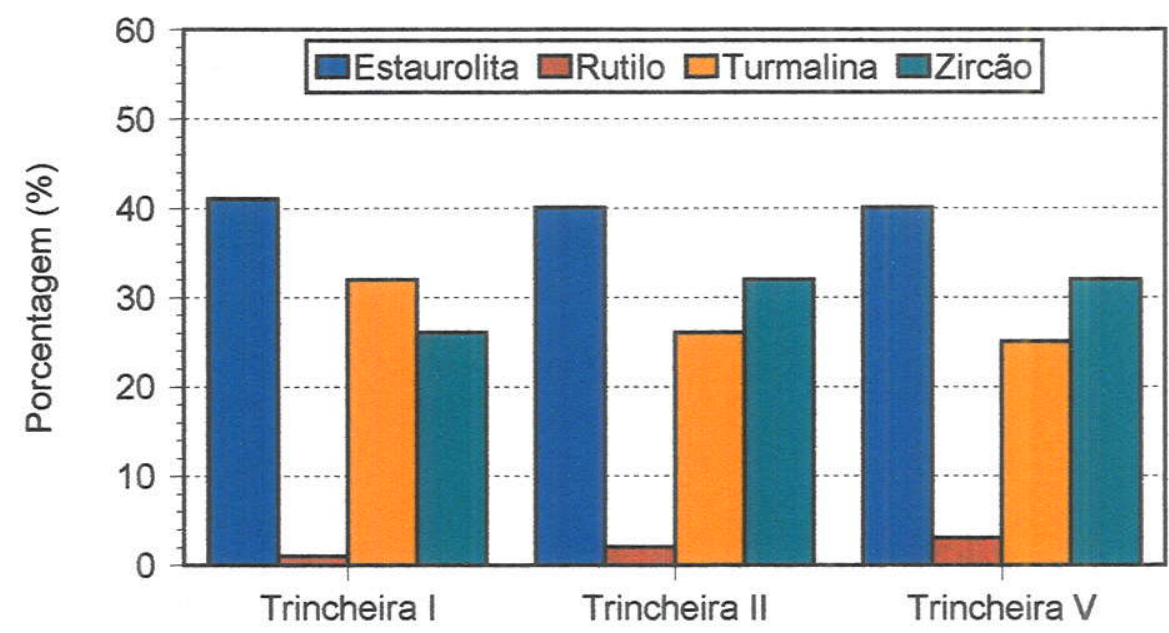

Toposseqüência São José

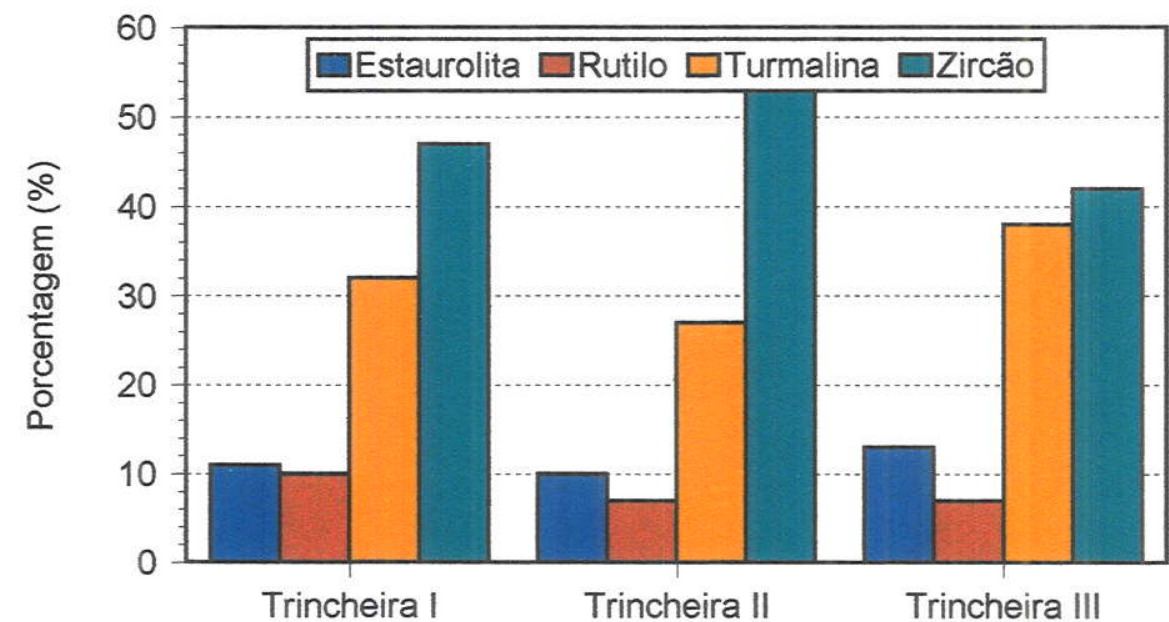

Fig. 3.14. Freqüência (\%) de minerais pesados que ocorrem nos perfis das trincheiras das várias toposseqüências estudadas 


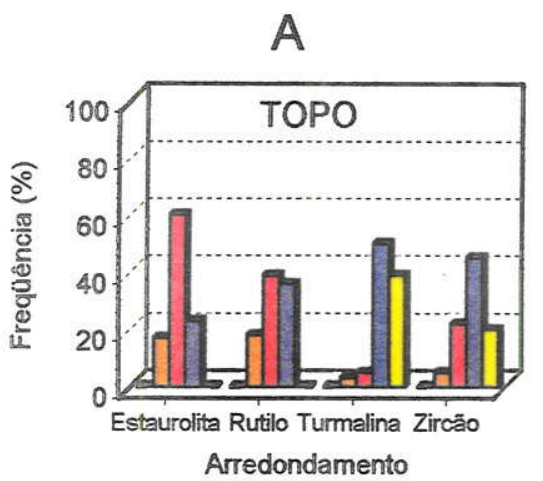

\section{B}
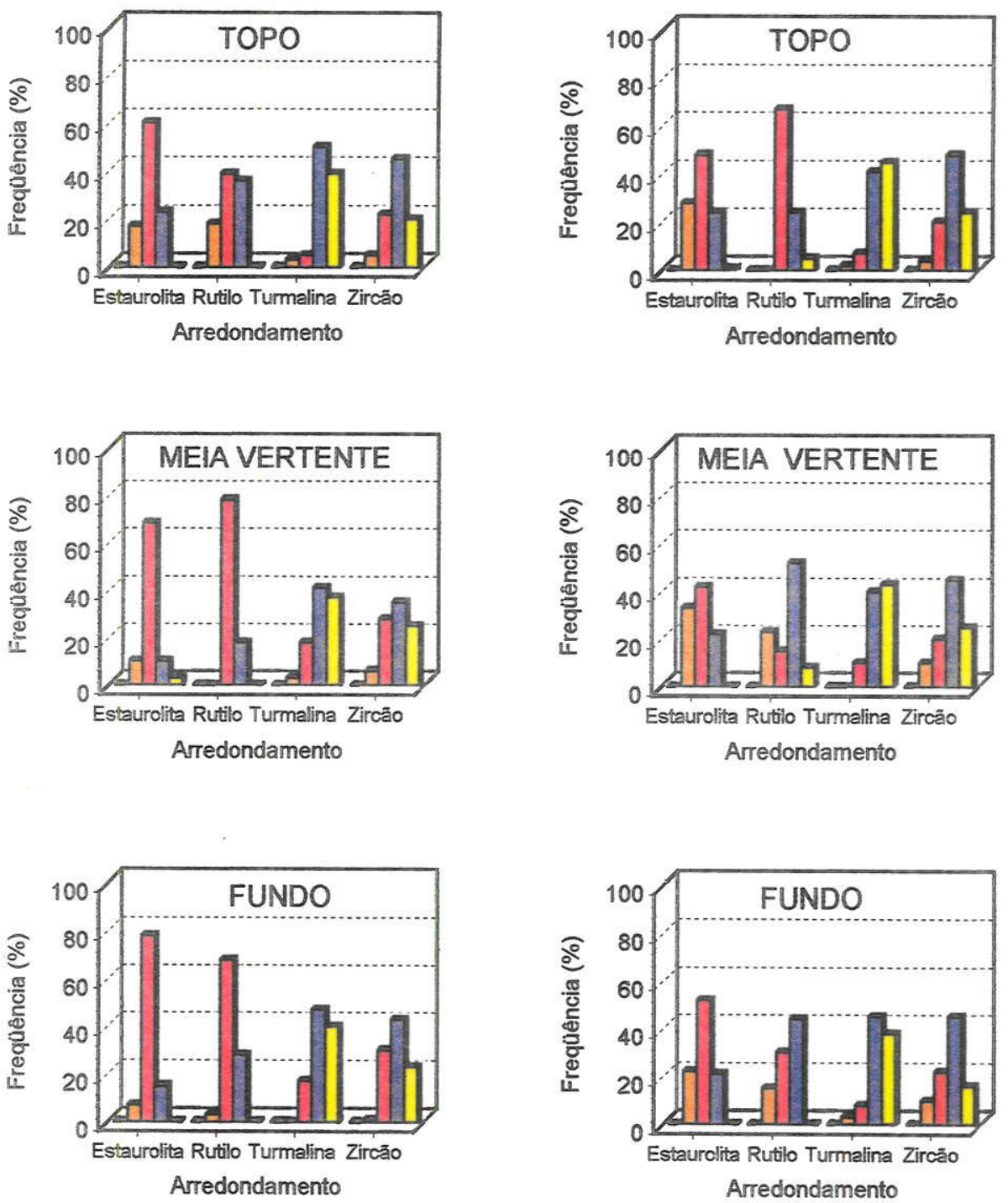

C
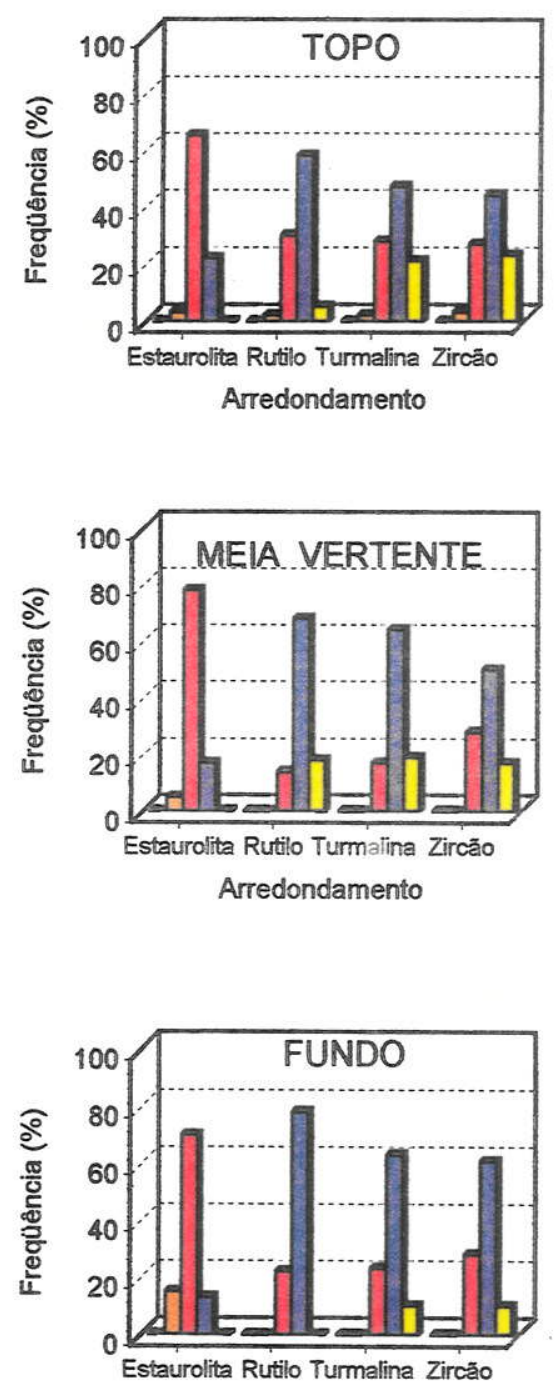

Arredondamento
D
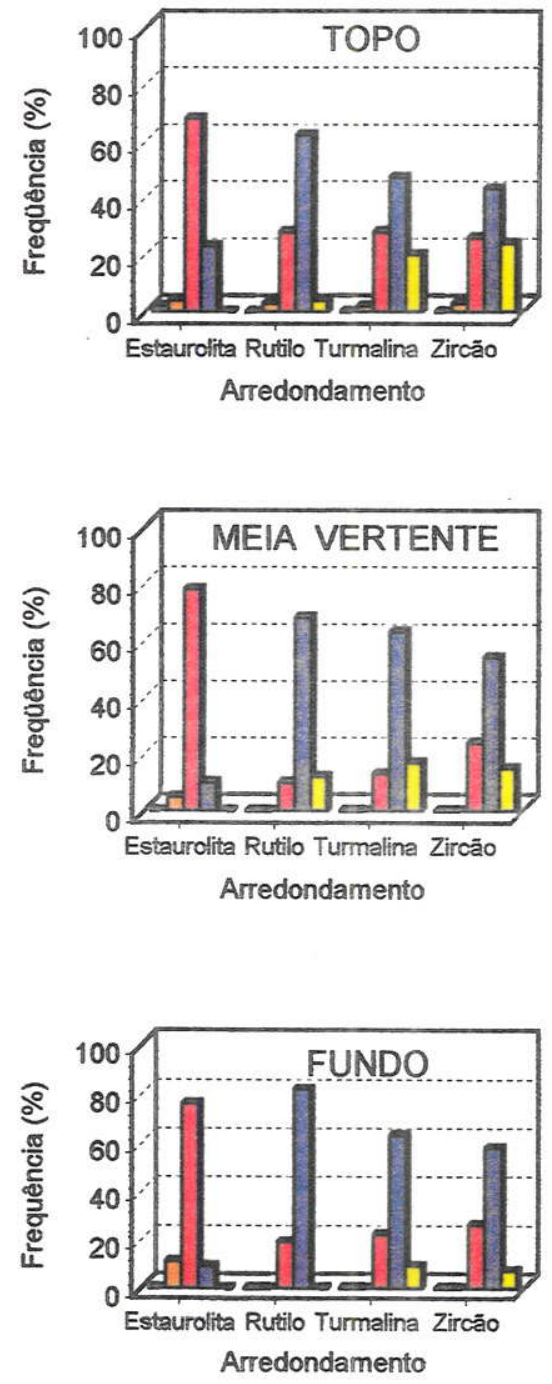

Anguloso $\square$ Subanguloso $\square$ Subarredondado $\square$ Arredondado $\square$ Bem Arredondado

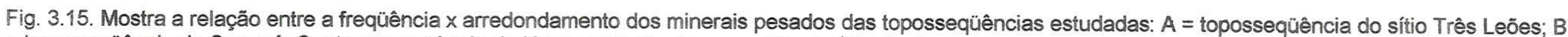
= toposseqüência de Sumaré; $C=$ toposseqüência de Umuarama; $D=$ toposseqüência São José 


\section{CAPÍTULO IV}

\section{A EVOLUÇÃO DAS FORMAÇÕES SUPERFICIAIS E AS SUAS RELAÇŌES COM O MODELADO E O ARENITO CAIUÁ}

O modelado paranaense apresenta-se como grandes superfícies aplainadas bastante dissecadas. As mais antigas estão representadas por testemunhos, alçados em relação à superfície atual, preservados por rochas de maior resistência à erosão. Essas superfícies foram elaboradas durante o Cenozóico, principalmente a partir do Terciário médio (Oligoceno). Segundo Bigarella et al. (1965), operaram sobre o arcabouço geológico estrutural do território paranaense sucessivos sistemas morfoclimáticos, responsáveis pelo desenvolvimento das formas atuais do relevo. Assim, como resultado dessas alternâncias, foram elaboradas várias superfícies de aplainamento de extensão regional, representadas pela superfície de cimeira e pelas interplanálticas, respectivamente pediplanos $\mathrm{Pd} 3, \mathrm{Pd} 2$ e Pd1. Elas foram provavelmente desenvolvidas no Oligoceno ( $\mathrm{Pd} 3$ ), no Plioceno inferior ( $P d 2)$ e no Plioceno superior/Pleistoceno inferior (Pd1). Seus remanescentes encontram-se amplamente distribuídos no Brasil (Bigarella et al., 1965).

No norte e noroeste do Paraná, de acordo com Justus (1985), o Pd1 apresenta inclinação da ordem de $1 \%$ em direção ao vale do rio Paraná; situa-se nas altitudes máximas entre $620 \mathrm{~m}$ e $630 \mathrm{~m}$, próximo ao contato com as superficies mais elevadas e mais antigas ( $\mathrm{Pd} 2$ e $\mathrm{Pd} 3$ ), e nas mínimas entre $380 \mathrm{~m}$ e $400 \mathrm{~m}$, próximo ao vale do rio Paraná. $\mathrm{Na}$ área de distribuição do Arenito Caiuá, emergem alguns relevos residuais, como aqueles dos Três Morrinhos e morro dos Três Irmãos, que corresponderiam a remanescentes da superfície $\mathrm{Pd} 2$ (desnivel de $130 \mathrm{~m}$ ), e pequenas elevações com desnivel inferor a $20 \mathrm{~m}$, mantidas por rochas ricas em óxidos hidratados de ferro e por carapaças e couraças ferruginosas (Justus, 1985).

Na região, o pediplano Pd1 corta as efusivas da Formação Serra Geral e os arenitos da Formação Caiuá. Popp \& Bigarella (1975), Justus (1985) e Bigarella \& Mazuchowski (1985) afirmam que essas rochas estão recobertas por formações supeficiais arenosas a argilosas, com espessuras variáveis que podem ultrapassar a $20 \mathrm{~m}$; pedogeneizadas, formando Latossolo Vermelho-Escuro, Latossolo Roxo e Areias Quartzosas. O contato com a rocha do substrato é erosivo fazendo-se às vezes por linha 
de pedra de origem coluvial.

Essas formações superficiais, que recobrem de maneira generalizada os interfiúvios e encostas, mostram, segundo Bigarella et al. (1965), Bigarella \& Mazuchowski (1985) e Justus (1985), evidências da sucessão de diferentes processos morfogenéticos relacionados às mudanças climáticas do Quaternário, como paleossolos, estruturas de dissipação, paleopavimentos rudáceos e os próprios materiais coluviais. Assim, após a última glaciação do período Quaternário, teriam predominado condições úmidas, levando a uma dissecação geral da paisagem. As flutuaçōes para o seco teriam dado origem a solifluxão extensiva, formação local de paleopavimentos rudáceos, deposição de sedimentos nas planícies de inundação e formação de terraços de várzeas (Bigarella et al., 1965).

Popp \& Bigarella (1975) consideram as seqüências arenosas que recobrem os †े afloramentos do Arenito Caiuá como uma formação passivel de mapeamento e li propuseram a denominação de Formação Paranavaí. Segundo esses autores, essa formação apresenta aspecto coluvial ou aluvial, em geral sem estruturas primárias ou estratificação nítida, sendo difícil a distinção entre o manto de intemperismo e o recobrimento de sedimentos (Cenozóicos). Justus (1985) inclui na Formação Paranavaí as carapaças e couraças ferruginosas pedogenéticas e os paleopavimentos encontrados no divisor entre as bacias do Ivaí-Piquiri.

Na cidade de Paranavaí, em uma voçoroca localizada na rua Piaui, Popp \& Bigarella (1975) descreveram as seqüências que compõem a formação. São quatro unidades, separadas entre si por discordâncias erosivas: a unidade mais antiga (seqüência 1) jaz em discordância erosiva sobre os estratos cruzados do Arenito Caiuá; a unidade mais recente (seqüência IV) correlaciona-se a uma rampa colúvio-aluvionar dissecada pela voçoroca. A seguir apresentam-se, de forma sucinta, a descrição e interpretação elaboradas pelos autores para as quatro seqüências:

- a seqüência I, na base do pacote, apresenta espessura variável, coloração castanhoavermelhada, assemelhando-se a um colúvio arenoso. As estruturas sedimentares são dificilmente identificadas, e apenas com uma observação mais detalhada é possivel perceber, com dificuldade, a presença de segmentos e planos horizontais alternados esparsos, remanescentes de fluxos arenosos densos. Essas feições lembram estruturas de dissipação. Por vezes ocorrem concentrações de pequenos fragmentos de arenito 
alterado, dando um aspecto conglomerático ao depósito;

- após a deposição da seqüência I, provavelmente em ambiente de floresta, processos pedogenéticos se instalaram, formando um perfil de solo. Uma nova crise climática, rompendo o equilibrio ambiental (retrocesso da floresta), intensifica os processos erosivos. Grande parte dos sedimentos da seqüência | foram, então, erodidos, deixando como vestígios do antigo perfil de solos (paleossolo) alguns remanescentes esparsos do horizonte B e C. Sobreposta à seqüência I, em inconformidade erosiva, encontra-se a seqüência II, constituída por areias castanho-claras até amareladas. De espessura irregular, sendo localmente mais espessa $(1,80 \mathrm{~m})$ do que as outras, caracteriza-se pela presença de estruturas de dissipação bem-desenvolvidas. Nela não foram encontrados vestígios de paleossolos;

- a seqüência II foi dissecada anteriormente à deposiçăo da sequência III. Os depósitos da última preenchem canais abertos na seqüencia inferior. A seqüencia III, de coloração esbranquiçada, também apresenta estruturas de dissipação evidentes, que se mostram como ondulações irregulares (estruturas de carga) ou lenticulares, diferenciadas pela concentração de material coloidal de cor cinza ou castanha (argila, óxidos de ferro hidratados e humatos). Além das camadas onduladas de continuidade lateral variável, encontram-se camadas contorcidas (estruturas de carga), bem como estruturas de corte e preenchimento salientadas pela impregnação com material coloidal. As estruturas de dissipação ressaltam e individualizam cada seqüência arenosa depositada por fluxos densos formados por corrida de areia;

- a seqüência superior IV está depositada em inconformidade erosiva sobre os estratos da seqüencia III. Encontra-se melhor preservada, terminando numa rampa suavemente inclinada para o centro do vale. É constituída por uma sucessão de camadas subparalelas irregulares, com $4 \mathrm{~cm}$ de espessura, coloração castanha, alternando com camadas claras de $6 \mathrm{~cm}$ a $10 \mathrm{~cm}$. As camadas arenosas apresentam estruturas de dissipação características. Segundo os autores (op cit.), as seqüências que constituem a Formação Paranavaí, elaboradas pela alternância de processos morfoclimáticos, testemunham as oscilações do clima durante o periodo Quaternário.

Entretanto, os resultados obtidos com os levantamentos de campo e análises dos materiais das toposseqüências estudadas nesta pesquisa mostram que as formações superficiais, associadas a essa superfície (Pd1), têm como material de origem $\circ$ Arenito 
Caiuá, alterado in situ, e as variações observadas ao longo das toposseqüências são produzidas por transformações pedológicas laterais (PRANCHA XII - Fotos 2 e 3).

Foram identificadas ao longo das toposseqüências os seguintes sistemas pedológicos: Areias Quartzosas/Latossolo Vermelho-Escuro (toposseqüências de Sumaré e Umuarama) e Areias Quartzosas/Solo Podzólico Vermelho-Escuro/Latosso VermelhoEscuro (toposseqüência do sítio Três Leões).

O primeiro sistema corresponde a vertentes instaladas sobre as porções mais altas dos interflúvios, de perfil convexo-côncavo, conectando o topo a vales em berço, sem a presença de cursos d'água permanentes e incisões verticais. O segundo está associado a vertentes convexas, situadas em setores rebaixados dos interflúvios, conectando o topo aos vales entalhados por cursos d'água permanentes (córregos). Apesar de nesta pesquisa ter sido analisada apenas uma vertente nessa situação, organizações semelhantes foram observadas por outros autores em diferentes localidades: a toposseqüência córrego Longe, em Umuarama (Cunha, 1996; Cunha \& Castro, 1998) - Fig. 4.1; e a toposseqüência Bom Jesus, no município de Cidade Gaúcha (Martins et al., 1998) - Fig. 4.2.

\section{Sistema pedológico Areias Quartzosas/Latossolo Vermelho-Escuro}

Com relação às toposseqüências de Sumaré e Umuarama, verificou-se que todos os volumes pedológicos identificados formam um conjunto de camadas sucessivas e paralelas à topografia, bem como os seus limites, confirmando uma evolução simultânea entre a pedogênse e a forma de relevo atual. Os volumes que mais sofrem perdas das frações finas são os superficiais e, de modo geral, ao longo de toda a toposseqüência. Entretanto, ocorre um empobrecimento lateral das frações finas em direção a jusante, atingindo toda a espessura da cobertura. Assim, a perda dos materiais finos favorece as acumulações relativas das fraçöes grosseiras e uma distribuição granulométrica diferenciada ao longo da vertente.

Ao microscópio se observam, nos setores de topo e alta vertente, maiores concentrações de plasma. No entanto, o plasma parece estar em desequilíbrio, uma vez 
que alguns cutãs estão fragmentados (PRANCHA VI - Fotomicrografia 4). Essa situação só é observada onde se dá a inversão na forma do perfil da vertente, que passa do topo plano-convexo para um perfil ligeiramente côncavo, que se prolonga até o fundo da vertente (Fig. 3.2). Essa forma ligeiramente côncava, nesse setor da vertente, estaria relacionada a abatimentos da superfície por perda de matéria, principalmente óxidos de ferro e argila, com conseqüente, rearranjos das organizações estruturais. Fenômeno semelhante ao encontrado nessa toposseqüência foi descrito para solos da região de Marilia, no estado de São Paulo, por Queiroz Neto (1988).

As características micromorfológicas da toposseqüência de Umuarama assemelham-se às da toposseqüência de Sumaré, isto é, as maiores concentrações do plasma encontram-se nas partes mais altas da vertente. No entanto, não foi observada, nas lâminas delgadas, a destruição de cutãs ou mesmo remobilização acentuada de material (plasma). O aumento do plasma no perfil ocorre de forma progressiva e contínua. Contudo, é possivel definir, com base nos teores de plasma, dois volumes: o primeiro, superficial, arenoso, pouco espesso e com estrutura de base predominantemente quitogefúrica; o segundo, subsuperficial, mais argiloso, espesso, com estrutura de base predominantemente enáulica, mas com domínios quito-gefúricos distribuidos de modo aleatório.

Remobilização de materiais, de montante para jusante, devem ter ocorrido no passado geológico. Esses materiais seriam provaveimente encontrados nos anfiteatros e nos vales em berço. Porém estudos granulométricos efetuados sobre essas feições do relevo não foram capazes de diagnosticar a presença de tais depósitos, pois a passagem do solo que recobre os interflúvios para aqueles que recobrem os anfiteatros e vales em berço se dá sem truncamento de camada ou seleção do material grosseiro, e ambos parece terem tido uma evolução única na paisagem. A única evidência passível de observação, nessa passagem, é a alteração de cor, uma vez que, à medida que se desce na vertente, os solos adquirem cores mais claras. A modificação de cor também é acompanhada da redução do teor de argila. A alteração da cor foi atribuida a processos de circulação hídrica lateral, que se intensificam à medida que se aproxima do sopé da vertente (Cunha, 1996). Entretanto, no sopé da toposseqüência de Umuarama, ocorre um depósito coluvial arenoso, que teve origem com o desmatamento da área. Esses depósitos rasos, bem-estratificados, localizados nos eixos dos vales em berço, são resultantes do escoamento superficial areolar que se intensificara na área durante a fase inicial de 
ocupação e de predomínio da cultura do café.

\section{Sistema pedológico Areias Quartzosas/Solo Podzólico Vermelho- Escuro/Latossolo Vermelho-Escuro}

Na toposseqüência do sítio Três Leões, o setor inferior da vertente não apresenta mais paralelismo dos horizontes pedológicos como o observado nas toposseqüências anteriores. Já a partir da média-vertente, ou média alta-vertente, aparece um volume em subsuperficie, mais argiloso que os adjacentes, que se inicia em forma de cunha e termina na baixa-vertente também em forma de cunha - é um horizonte Bt. No sopé da vertente, a partir do terço inferior, o volume arenoso se espessa e jaz diretamente sobre a alteração do Arenito Caiuá. No contato, envolvendo às vezes parte do horizonte Bt, ocorre uma concentração nodular que desaparece em direção a montante. Nesse horizonte arenoso mais espesso são observadas bandas onduladas formadas por material mais argiloso do que aquele que as envolve (PRANCHA XII - Foto 1). Essas bandas, entretanto, são mais abundantes e contínuas em direção a montante, quando o volume arenoso transiciona lateralmente para o Bt; a jusante, são mais finas e fragmentadas, desaparecendo totalmente no sopé da vertente. Essas feições foram também observadas nas outras duas toposseqüências estudadas por Cunha (1996), Cunha \& Castro (1998) e Martins et al. (1998). Essas bandas se destacam do resto do volume pela cor (em geral são vermelhoamareladas) e pela textura (mais argilosas). Cunha (1996), na toposseqüência córrego Longe (Umuarama), interpretou essas bandas como relíquias do horizonte Bt, em razão das características do material que as compõe e, principalmente, pela ligação física através de pedúnculos que algumas, as mais a montante, ainda mantêm com o horizonte Bt. Situações semelhantes foram observadas e assim interpretadas por Castro (1989) na região de Marília, e por Santos (1995) na região de Bauru. Essas carcaterísticas das bandas onduladas sugerem, portanto, sua formação às expensas da destruição, a jusante, do horizonte Bt.

Assim, as estruturas de dissipação descritas na Formação Paranavaí, ou simplesmente no recobrimento colúvio-aluvionar, como se referem vários autores, sempre em posição de sopé de vertente com entalhe vertical, parecem corresponder a essas 
bandas onduladas. Da mesma forma, as concentrações nodulares, presentes nesse setor das vertentes, podem corresponder aos pavimentos paleorudáceos descritos por Popp \& Bigarella (1975) e Justus (1985).

Essas feições surgem freqüentemente nos setores das bacias onde as vertentes apresentam formas convexas relacionadas ao entalhe do curso d'água, no sopé da vertente, que atualmente tende a acelerar os fluxos hídricos nesse setor. Esses fluxos promovem a transformação da cobertura pedológica de jusante para montante pela invasão das Areias Quartzosas sobre o Solo Podzólico Vermelho-Escuro, enquanto que na média alta-vertente o horizonte $\mathrm{Bt}$ ainda avança lateralmente sobre o $\mathrm{BW}$.

A dinâmica dos fluxos hídricos no sopé da vertente tende a ser modificada em decorrência do nível de base local. Essas mudanças tanto podem ocorrer em razão de mudanças climáticas, como de eventos tectônicos, das condições hidrológicas de superfície, ou mesmo em decorrência da facilogia apresentada pelo Arenito Caiuá. Essas tranformações são observadas com freqüência nas vertentes desenvolvidas sobre os interflúvios mais rebaixados, terminando com a presença de uma incisão vertical, de profundidade variável, com drenagem permanente.

\section{Considerações sobre o paleoclima}

As alterações climáticas ocorridas, principalmente aquelas no final do período Pleistoceno e durante o Holoceno, promovendo de modo alternado períodos glaciais, com redução de chuvas, e interglaciais com aumento de umidade, influenciaram os processos geomorfológicos, sedimentológicos, pedológicos, bem como a distribuição da vegetação. Entretanto, intercalados dentro desses períodos mais prolongados (glaciais e interglaciais) foram também reconhecidos episódios úmidos e secos de curta duração responsáveis por mudanças localizadas, restritas a pequenas porções de determinadas regiões (Suguio et al., 1985; Behling, 1995a, b).

Nos últimos anos, com o avanço dos conhecimentos obtidos com análises detalhadas de laboratório, utilizando critérios sedimentológicos e dados palinológicos, ampliaram-se de forma significativa os conhecimentos, permitindo que fossem demarcadas 
com certa precisão, em termos cronológicos, as mudanças de clima semi-árido para clima com maior precipitação, ocorridas na região centro-sul do Brasil, mais precisamente na passagem do Pleistoceno/Holoceno (Schimitz, 1990; Neves, 1991; Jabur, 1992; Clapperton, 1993; Ledru, 1993; Stevaux, 1993; Souza Filho, 1993; Thomaz \& Thorp, 1996; Behling, 1995a e b; Santos, 1997; Thomaz, 1999).

Os trabalhos desenvolvidos pelo Grupo GEMA-DGE-UEM (Grupo de Estudos Multidisciplinares do Ambiente do Departamento de Geografia da Universidade Estadual de Maringá), efetuados na bacia hidrográfica do rio Paraná, curso superior, permitiram que fosse realizada a reconstituição, pelo menos parcialmente, da evolução das várias fases por que passou o rio Paraná, bem como do desenvolvimento da vegetação daquela área.

Jabur (1992) realizou uma ampla revisão dos trabalhos que empregavam dados sedimentológicos e palinológicos, na região centro-sul do Brasil, e, com base em dados palinológicos coletados junto aos rios Piquiri, Esperança e Pinhalzinho, determinou as variações climáticas ocorridas nos últimos 25.000 anos antes do presente (A. P.), para a região.

Para Jabur (1992), o intervalo compreendido entre 25.000 e 10.000 anos A. P. caracteriza-se pela predominância de clima semi-árido alternado com dois períodos úmidos de menor duração. Os períodos de clima mais seco favorecem o desenvolvimento de gramíneas e vegetação aberta. Esses dados são confirmados por Bigarella et al. (1994) ao comentar que os periodos glaciais, registrados no hemisfério Norte, se refletiram no hemisfério Sul com a redução da umidade, e que as florestas tropicais foram sendo substituídas por formações mais abertas típicas de clima semi-árido. Ambos os autores salientam que na passagem de um clima para outro ocorre uma fase de transição.

Ao analisar a Fig. 4.3, verifica-se que o limite superior desse intervalo climático, que marca a passagem do Pleistoceno/Holoceno, bem como os demais limites, encontram-se defasados temporalmente, dependendo da região estudada. A nãocoincidência desses limites deve-se às posições geográfica e topográfica da região ante as variações climáticas (Ledru, 1993).

O período compreendido entre 8.000 e 4.000 anos A. P. é caracterizado pela presença de um clima mais ameno, se comparado com o período anterior, definido por um intervalo transicional evoluindo para a instalação de um clima mais úmido, que irá 
transcorrer durante o Holoceno inferior. $\mathrm{Na}$ área de estudo, esse intervalo de tempo é marcado pela presença de pólens de floresta úmida e vegetação de várzea (Jabur, 1992). No rio Paraná, predomina a fase de deposição de sedimentos finos, originados pelo predomínio da alteração química, tendo como conseqüência mudança no padrão do sistema fluvial, que evolui para anastomosado (Stevaux, 1993; Stevaux, 1994; Santos, 1997).

Um periodo seco, compreendido entre 3.000 e 2.000 anos A. P., foi confirmado na região noroeste do Paraná pela presença de pólens de vegetação de cerrado, grande desenvolvimento de cactáceas, que avançou sobre a floresta úmida (Jabur, 1992). Relictos da vegetação desse período estão preservados e podem ser observados numa reserva florestal do munícipio de Campo Mourão.

A partir de 2.000 anos A.P., o clima volta a ser úmido e assim permanece até o presente. Esse período de tempo está bem-caracterizado pela presença abundante de pólens típicos de florestas que se desenvolvem em climas úmidos (Jabur, 1992; Thomaz, 1999).

Dessa forma, o entalhe da superfície Pd1, o modelado das vertentes e a evolução das formações superficiais e da sua organização pedológica estiveram sujeitos às variações climáticas a partir do Pleistoceno e, mais particularmente, das variações do Quaternário.

Entretanto, o levantamento das toposseqüências $e$ as observações micromorfológicas não revelaram nenhuma evidência que possa ser diretamente associada a essas mudanças climáticas ocorridas durante 0 Quaternário na região. Esse fato pode ser explicado, de um lado, pela situação das toposseqüências em áreas preferenciais de saída de matéria (topos dos interflúvios principais) e, de outro lado, pelo tempo de duração das alterações climáticas, que nesse caso não teriam sido suficientemente longas para produzir modificações nos perfis de solos (superposição de características morfológicas, geração de feições morfológicas, pedorreliquias, etc.) ou no modelado das vertentes (geração de rupturas de declive, de patamares, etc.). Assim, a variação lateral da organização pedológica observada parece ser resultante do recuo das cabeceiras sobre o interflúvio e do aprofundamento dos vales.

A partir das considerações realizadas anteriormente, verificou-se que todos os 
volumes identificados formam um conjunto de camadas sucessivas e paralelas à topografia, bem como seus limites (exceção da porção terminal da toposseqüência do sítio Três Leões), confirmando uma evolução simultânea entre a pedogênese e a evolução do relevo atual. A não-acumulação de argila em profundidade nas porções de alta-vertente, e sua conseqüente acumulação nos volumes mais profundos, verificadas à medida que se desce na topografia, seriam evidências que reforçariam a migração lateral. Dessa forma, as diferenciações ocorridas nos volumes superficiais, ao longo das toposseqüências, seriam ocasionadas pela redistribuição dessas frações, bem como da diferenciação dos volumes em profundidade e na lateralidade.

As análises micromorfológicas realizadas a partir de lâminas delgadas permitiram uma meihor compreensão dos processos de origem das formações superficiais e da organização da cobertura pedológica na região noroeste do Paraná. Os latossolos microagregados, que predominam nas superficies dos topos suaves, formaram-se provavelmente pela alteração química do Arenito Caiuá. Isso pode ser confirmado pela ocorrência do latossolo sob o volume $\mathrm{Bt}$, ao longo de toda a vertente. Posteriormente, ou concomitantemente à formação do latossolo, se dá a instalação de um sistema que transforma o volume microagregado em volume $B$ textural com estrutura poliédrica bemdesenvolvida. No topo do volume com estrutura poliédrica, devido à diminuição da porosidade e capacidade de infiltração, surge um processo de hidromorfia, o qual é responsável pela remobilização da argila, favorecendo o surgimento de um volume arenoso superficial. Finalmente, no sopé da vertente instala-se um sistema de transformação remontante, em que se dá a separação do plasma do esqueleto, favorecendo o acúmulo relativo deste último e tendo como conseqüência o aumento da espessura do volume arenoso superficial. Essa transição é considerada uma frente de transformação, com evacuação do plasma e acumulação relativa do esqueleto. As frações mais finas do plasma (formadas por soluções e elementos dissolvidos) são evacuadas da bacia pelas drenagens instaladas no fundo da seqüência. Nesse caso, a evolução da cobertura pedológica é acompanhada por um rebaixamento da superfície topográfica, correspondente às perdas da matéria que acompanham as transformações.

Esses aspectos mostram que a cobertura pedológica é contínua ao longo de toda a vertente, com provável filiação genética entre os volumes; o $B$ latossólico evolui para o volume Bt e este para o volume arenoso superficial. De todos os horizontes, o B latossólico encontra-se em transformação, sob as condições atuais de clima, embora, no conjunto, sua 
evolução para o Bt seja concordante com a evolução da vertente, já que ambos os horizontes são paralelos à topografia atual. Essas características comprovam, nessas vertentes, que a cobertura pedológica encontra-se em transformação. Transformações como essas podem ser originadas por mudanças climáticas globais ou por modificação do nivel de base local ou regional, favorecendo um aprofundamento vertical da rede de drenagem no sopé da vertente (Boulet, 1992; Boulet et al., 1993; Pellerin \& Queiroz Neto, 1992; Filizola, 1993).

Nas toposseqüências de Sumaré e de Umuarama essas transformações são menos evidentes, em decorrência do fato de os setores terminais das toposseqüências não atingirem os córregos, fazendo com que as flutuações do lençol freático, apesar de existirem, sejam amenizadas, não acarretando modificações bruscas, como as verificadas na toposseqüência do sítio Três Leões. Desse modo, as modificações da cobertura pedológica são mais evidentes no sopé da vertente do que no topo, embora essas transformações progridam em direção a montante, podendo inclusive abranger toda a vertente.

Outros dois fatos que chamam a atenção são:

- nas três toposseqüências estudadas, o esqueleto da cobertura pedológica jamais apresenta alguma orientação, com exceção do esqueleto encontrado nos nódulos ferruginizados da toposseqüência sítio Três Leões e na porção terminal da toposseqüência de Umuarama, onde está localizado o depósito coluvial. A ausência de orientação do esqueleto da cobertura pedológica pode ser indicativo de que a alteração se processou diretamente do Arenito Caiuá sotoposto, sem nenhum deslocamento capaz de orientar os grãos do esqueleto. Segundo Young (1976) e Mcfarlane \& Bowden (1992), esses critérios, quando presentes, são um forte diagnóstico de alteração in situ. Para Boulet et al. (1993), essa homogeneidade na distribuição do esqueleto pode estar relacionada também à não-presença de forças internas, principalmente do regime hídrico, que deveria ser estável nos volumes, não permitindo o aparecimento de domínios orientados, e também à pequena ocorrência ou inexistência de minerais argilosos expansíveis.

- não-concentração de uma espécie de mineral pesado ao longo das toposseqüências também é um argumento muito consistente para a interpretação de origem das formações superficiais a partir da alteração in situ. Young (1976) e Mcfarlane \& Bowden 
(1992) consideram que esse aspecto confirmaria a existência de coberturas residuais. As variações de concentração das diferentes espécies de minerais pesados, verificadas entre as toposseqüências, estão mais relacionadas com mudanças faciológicas sofridas durante a deposição do Arenito Caiuá do que com as alterações pedogeoquímicas ou mesmo com processos de retrabalhamento. 
PRANCHA XII

\section{TOPOSSEQÜENNCIA DO SITIO TRÉS LEŐES}

Foto 1: detalhe do volume arenoso (E) com bandas onduladas finas $(0,5 \mathrm{~cm}$ a $2,5 \mathrm{~cm}$ de espessura), que se tornam bem visíveis em razão do seu maior conteúdo em argila, tornando-as mais avermelhadas, tendendo a desaparecer completamente em direção ao topo do perfil

Foto 2: aspectos de alteração do Arenito Caiuá para solo comumente encontrado no sopé das vertentes. Na base do perfil da TR-5 aparece o arenito alterado, estratificado, com inúmeras fissuras de cor mais clara preenchidas por material mais fino. Em direção ao topo as características do arenito vão sendo destruídas, gradando para o solo e o volume nodular
Foto 3: detalhe do Arenito Caiuá alterando-se para solo nos topos dos interflúvios mais elevados da região. Verificar que na base 0 arenito apresenta estratificação plano-paralela bem característica entremeada por bolsões de alteração de diferentes formas e tamanhos. Em direção ao topo a estrutura do arenito começa, de modo contínuo, a desmantelar-se para originar o solo 

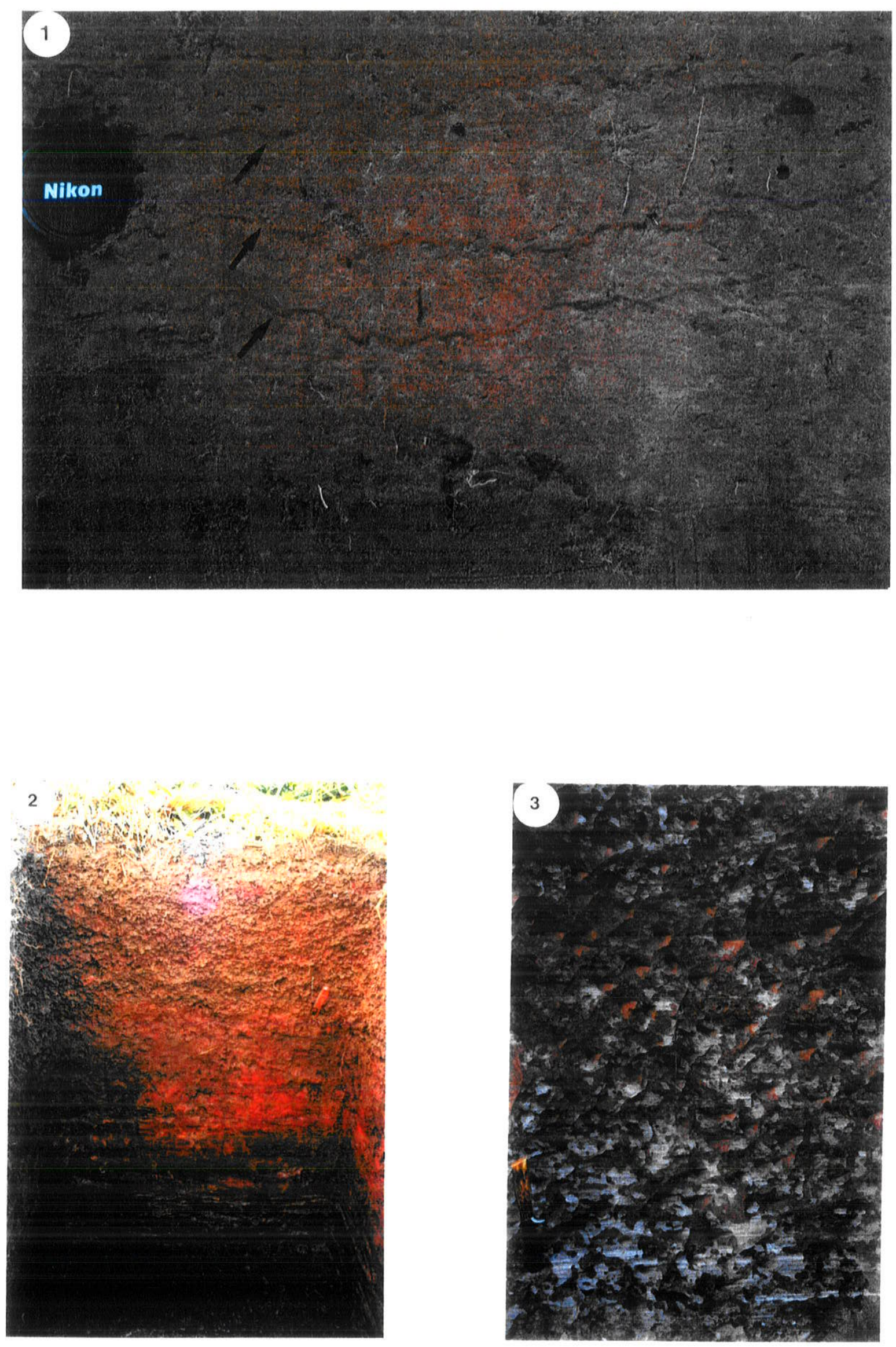


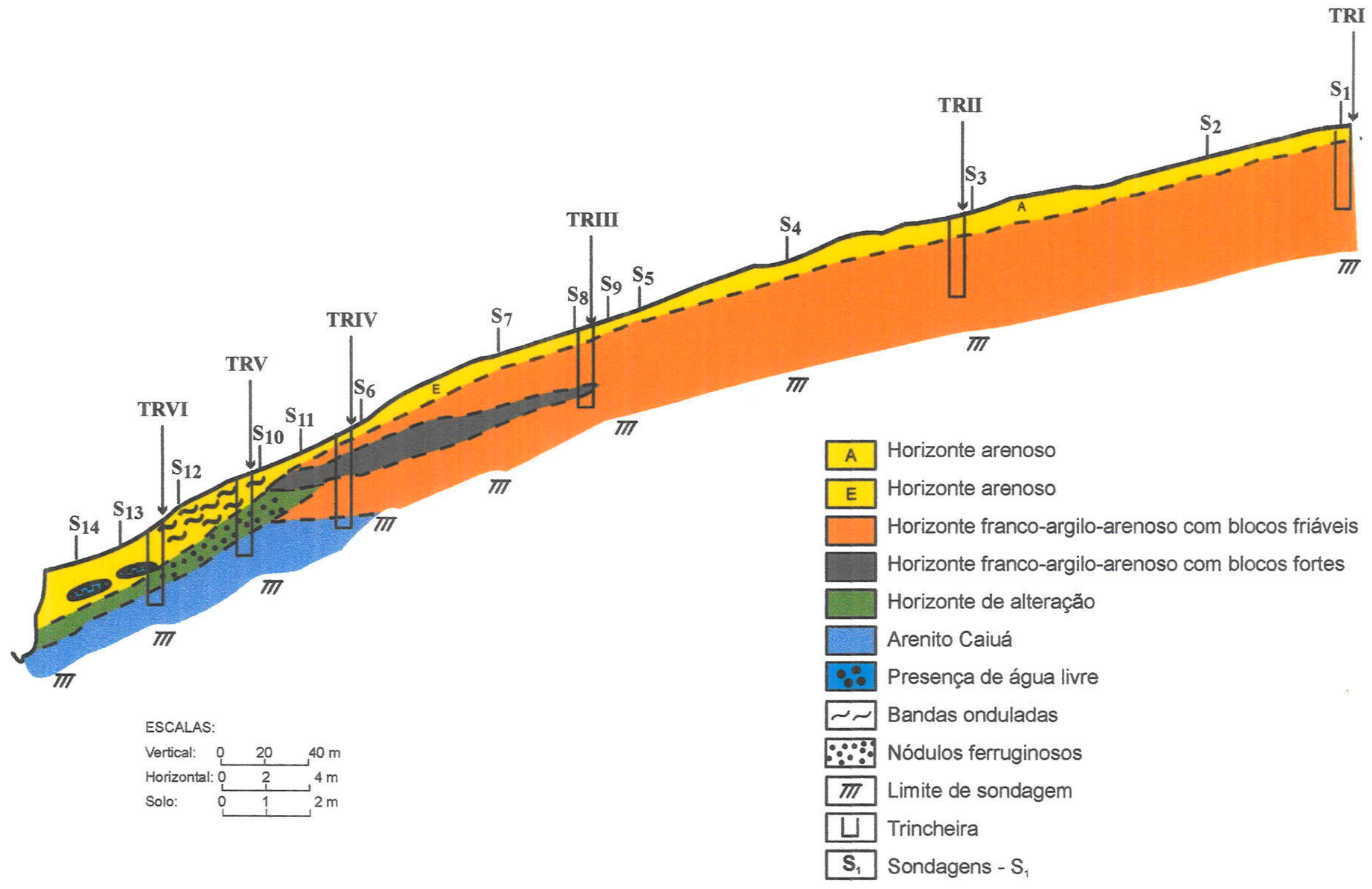

Fig.4.1. Toposseqüência córrego Longe - Umuarama (Cunha, 1996) 


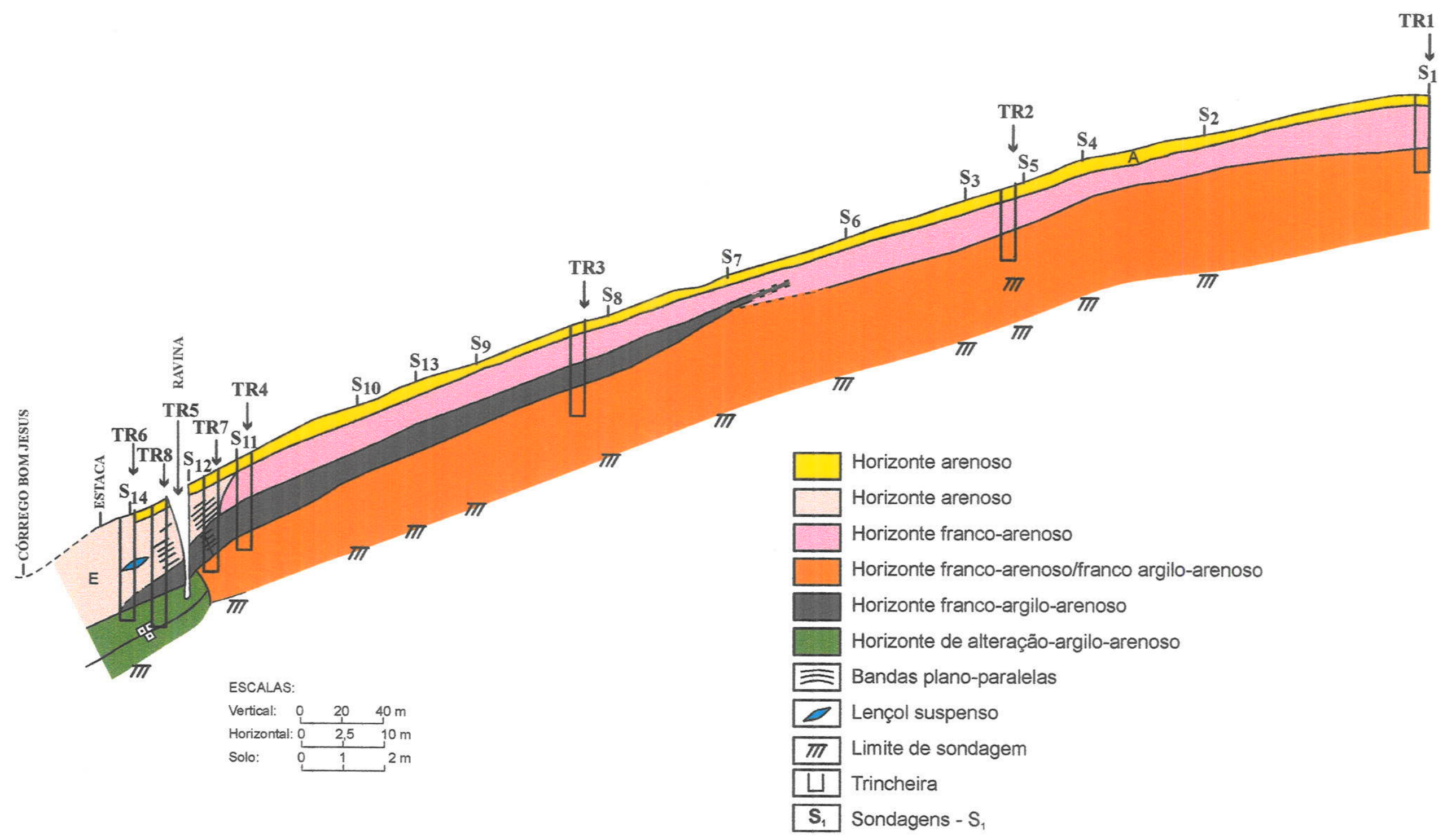

Fig.4.2. Toposseqüência córrego Bom Jesus - Cidade Gaúcha (Martins et. al., 1998) 

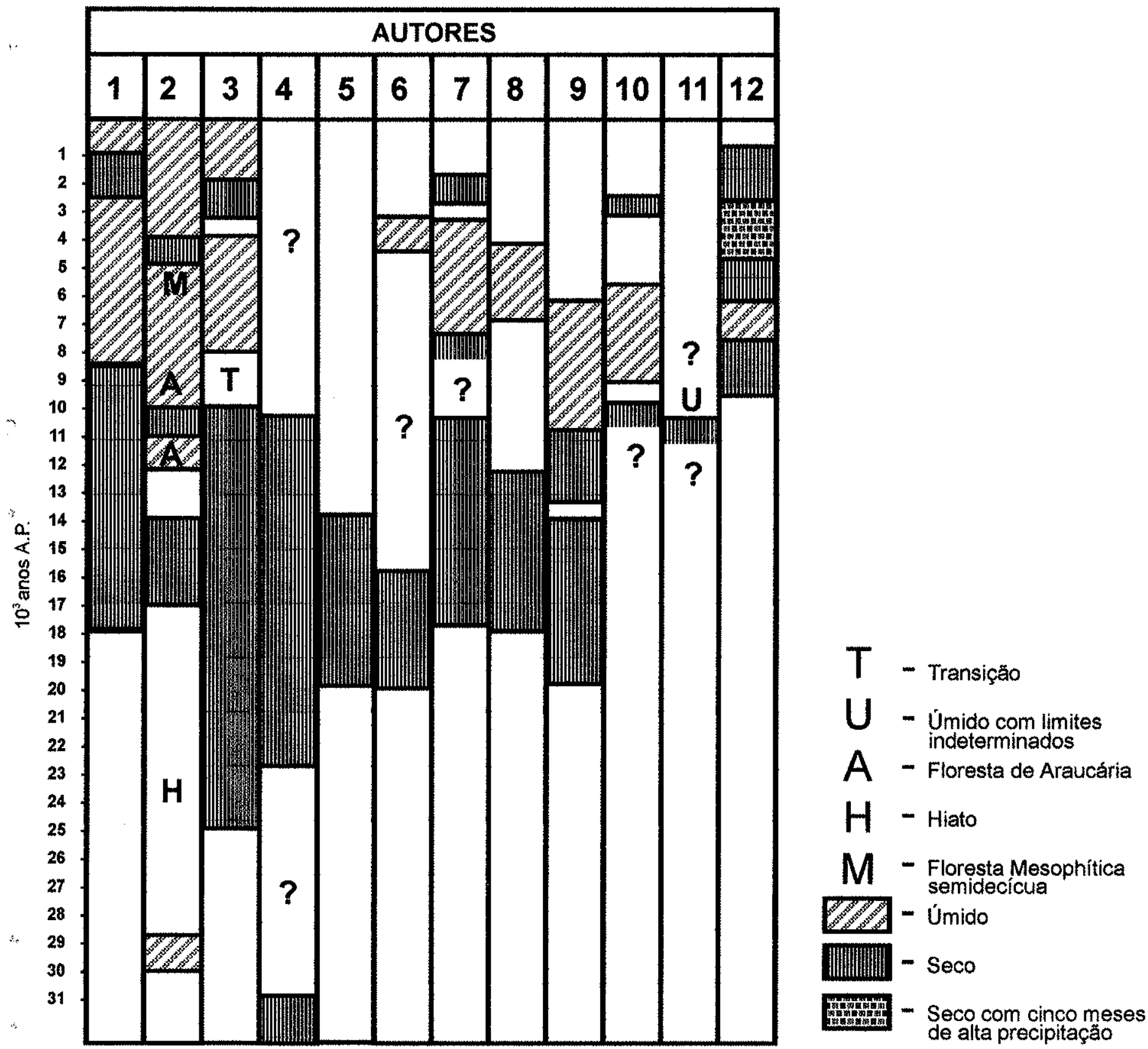

1 - Iriondo \& Garcia (1993), Planície Chacopampeana

2 - Ledru (1993), Brasil Central

3 - Jabur (1992), regiäo de Porto Rico

4 - Soubides et al. (1991) apud Clapperton (1993), serra dos Carajás

5 - Cordeiro (1991) litoral do Rio Grande do Sul

6 - Neves (1991) litoral do Rio Grande Sul

7 - Barbosa et al. (1991), sul de Goiás

8 - Shimitz (1991), geral

9 - Vander Hammen (1990), oeste do Rio Grande do Sul

10 - Bigarella (1971 e 1974), litoral do Paraná

11 - Roth \& Lorcheistter (1991) Rio Grande do Sul

12 - Behling (1995 a), Brasil Central

Fig. 4.3. Mostra os diferentes intervalos climáticos na passagem Pleistoceno/Holoceno, definidos por vários * autores, a partir de estudos efetuados na região centro-sul do Brasil e NE da Argentina (Santos, 1997) 


\section{CONSIDERAÇÕES FINAIS}

As formações superficiais, constituídas basicamente por latossolo vermelhoescuro, que recobrem quase que totaimente o Arenito Caiuá, na região noroeste do Paraná, são geralmente consideradas como tendo evoluído de materiais coluviais originados durante as oscilações climáticas do Quaternário. Entretanto, estudos detalhados através de toposseqüências, efetuados sobre as formações superficiais que ocorrem sobre os topos dos interflúvios mais elevados, permitiram reconsiderar essa hipótese.

Os horizontes do solo estão organizados numa sucessão vertical, sem truncamento de camadas, paralelos à superfície que se desenvolve ao longo de toda a vertente. As espessuras dos volumes variam lateralmente quando a declividade torna-se mais acentuada, provocando o adelgaçamento dos horizontes subsuperficiais, principalmente se a rocha alterada estiver mais próxima, e o espessamento dos horizontes superficiais.

O esqueleto constituído predominantemente por grãos de quartzo não apresenta orientação, com exceção daquele encontrado no interior dos nódulos ferruginosos do final da toposseqüência do sítio Três Leões e no sopé da vertente de Umuarama, onde ocorre um depósito coluvial. Em geral, a ausência de orientação do esqueleto é um forte indicativo de que a alteração se processou diretamente do Arenito Caiuá sotoposto, sem deslocamentos capazes de orientar os grãos.

As análises micromorfológicas mostram que ao longo das seqüências ocorre transferência de matéria, confirmada por diferentes organizações pedológicas, isto é, através de estruturas que demostram perda de matéria e aquelas que indicam reorganização com acumulação de matéria (cutãs). As principais feições que representam perda de máteria são o desmantelamento da estrutura porfírica, que se transforma em quitônica, enaúlica e mônica pela remobilização do plasma; fissuração, fragmentação e deslocamento de pequenos fragmentos de cutãs e de nódulos ferruginosos; presença de domínios, nos horizontes superiores, com perdas acentuadas de argila; dissolução do esqueleto, tendo como conseqüência o aumento da porosidade e acumulação relativa do esqueleto. Todas essas feições, em geral, estão associadas aos volumes superficiais de todas as toposseqüências estudadas. Ao contrário, as estruturas que representam ganho 
de matéria estão assim identificadas: transformação, por acumulação de argila, das estruturas quitônica e enaúlica em porfírica; preenchimento dos poros maiores, dando origem a cutãs; redução acentuada da porosidade. Essas estruturas de adição de matéria ocorrem nos volumes subsuperficiais, principalmente quando se desenvolvem volumes com B textural. Essas mudanças caracterizam coberturas superficiais em transformação, pois é visível a mudança do B latossólico em B textural, a partir da média alta-vertente, e deste em Areias Quatzosas no final da vertente da toposseqüência do sítio Três Leões, enquanto que para as toposseqüências de Sumaré e de Umuarama os Latossolos Vermelho-Escuros do topo gradam para Areias Quatzosas em direção ao sopé da vertente.

Os perfis de solos são formados por materiais arenosos, e a distribuição das frações grosseiras seguem um padrão semelhante ao encontrado no Arenito Caiuá. Análises da superfície dos grãos de quartzo demostraram que existe uma semeihança, bastante significativa, entre os materiais das formações superficiais e os sedimentos que compõem o Arenito Caiuá. Ambos são formados, predominantemente, pelas frações areia fina a muito fina, moderadas a bem-selecionadas. Quanto a forma, os grãos mostram-se arredondados a bem-arredondados, com alto grau de esfericidade, principalmente nas frações grosseiras. Essas medidas tendem a diminuir com a redução do tamanho dos grãos. As descrições micromorfológicas mostraram que o material de origem das formações superficiais, nas três toposseqüências, é o mesmo, provavelmente, do Arenito Caiuá.

Um dos critérios utilizados por diversos pesquisadores, para difinir a existência da cobertura coluvial que recobre o Arenito Caiuá, foi o dos valores obtidos pelos parâmetros estatísticos de Folk \& Ward (1957). O valor do diâmetro médio para as formações superficiais geralmente indica a predominância de materiais mais finos, portanto diferente daqueles valores obtidos para o Arenito Caiuá. Porém, quando se elimina a fração fina de ambos os materiais e analisam-se as frações grosseiras, os valores dos parâmetros estatísticos são semelhantes $e$, se usados isoladamente, não se prestam para a caracterização e identificação dos materiais.

A composição mineralógica das formações superficiais e do arenito é constituída basicamente por quartzo, raros feldspatos e minerais pesados opacos e transparentes não-micáceos. A assembléia de minerais pesados é formada por estaurolita, rutilo, turmalina e zircão, o que sugere uma alta maturidade textural e mineralógica para os 
materiais das formações superficiais que recobrem a Formação Caiuá.

Análises qualitativas da fração fina (MEV-EDS) demonstraram que a matriz do arenito e o plasma das formações superficiais apresentam a mesma composição química, constituída basicamente por caulinita pobremente cristalizada e por hidróxidos de ferro. Essa associação mineralógica caracteriza ambientes lixiviados e formações superficiais bastante evoluidas, refletindo o intemperismo agressivo que os afetou. A não-mudança de composição dos minerais dos perfis sugere que existe somente um material de origem para as formações superficiais.

As vertentes onde foram analisadas as toposseqüências estão relacionadas a uma superfície de erosão definida por Bigarella et al. (1965) como Pd1, que desde o final do período Terciário vem sendo remodelada sob condiçöes climáticas que, durante o Quaternário principalmente, se alternaram entre periodos mais secos e periodos mais úmidos. Contudo, as oscilações climáticas não deixaram nesses materiais vestígios claros. As oscilações climáticas mais recentes (últimos 25.000 anos A.P.) identificadas na região não foram suficientemente longas para deixar testemunhos.

As variações laterais observadas na organização da cobertura pedológica são resultantes do recuo das cabeceiras de drenagem sobre os interflúvios e do aprofundamento dos vales. Os mecanismos que controlam esse recuo e o aprofundamento podem ser de origem climática e tectônica.

Acredita-se, portanto, que as formações superficiais ocorrentes na região noroeste do Paraná tenham sido originadas a partir do Arenito Caiuá por alteração in situ, e que, se houve remobilizações de materiais ao longo das vertentes, estes são de difícil identificação. Quando ocorrem, estão relacionados a fundos de vales, nichos de nascentes e pequenas bacias de recepção. No entanto, a mobilidade de materiais torna-se clara quando há depósitos coluviais, de origem antrópica, formados após a retirada da mata. 


\section{BIBLIOGRAFIA}

AB'SÁBER, A. N. - 1960 - Posição das superfícies aplainadas no Planalto Brasileiro. In: Notícias Geomorfológicas 5, Campinas.

ALMEIDA, M. A.; STEIN, D. P.; MELO, M. S.; BISTRICHI, C. A.; PONÇANO, W. L.; HASUI, Y \& ALMEIDA, F. F. M. - 1980 - Geologia do oeste paulista e áreas fronteiriças dos estados do Mato Grosso do Sul e Paraná. In: CONGRESSO BRASILEIRO DE GEOLOGIA, 31. Balneário Camboriú, Anais..., Balneário Camboriú, SBG, v. 5, p 27992812.

ARID, F. M.; BARCHA, S. F. \& MEZZALIRA, S. - 1981 - Contribuição ao estudo da Formação Caiuá. São Paulo, R. IG., 2(1):5-20.

ASSEEZ, L.O. - 1972 - Triangular presentation of textural data in the interpretation of depositional environments. J. Sed. Petrol., 42(3):729-731.

AZEVEDO, A. A. B. \& MAZZOLI, M. - 1984 - Geologia da Folha de Aguaí, SP. São Paulo, R. IG, 5(1/2):39-46.

BACKER, C. L. - 1923 - The lava fiel of the Paraná basin, South América. J. Geol., 31:6679.

BASU, A. - 1985 - Reading provenance from detrital quartz. Dept. of Geology, Univ. Indiana. PROVENANCE OF ARENITES, ed. G.G. Zuffa., Dept. of Earth Sci. University of Calabria, Italy.

BEHLING, H. - 1995a - A high resolution holocene pollen record from Lago do Pires, SE Brazil: vegetation, climate and fire history. J. of Paleontology, 14:253-268.

BEHLING, H. - 1995b - Investigations into the Late Pleistocene and Holocene history of vegetation and climate in Santa Catarina (Sul do Brasil). Vegetation History and Archaeobotany, 4:127-152.

BELLIENI, G; BROTZU, P.; COMIN-CHIARAMONTI, P.; ERNESTO, M.; MELFI, A. J.; PACCA, I. G. PICCIRILLOO, E. M. \& STOLFA, D. - 1983 - Petrological and paleomagnetic data on the plateau basalt to rhyolite sequences of the southern Paraná basin (Brazil). Acad. Bras. Ciênc., 55:355-383.

BELLIENI, G; BROTZU, P.; COMIN-CHIARAMONTI, P.; ERNESTO, M.; MELFI, A. J.; PACCA, I. G. PICCIRILLO, E. M. \& STOLFA, D. - 1984 - Flood basalt to rhyolite suites in the southern Paraná plateau (Brazil): paleomagnetism, petrogenesis and geodynamic implications. J. Petrol., 25:579-618.

BELLIENI, G; COMIN-CHIARAMONTI, P.; MARQUES, L. S.; MELFI, A. J.; NARDY, A. R. J.; PAPATRECHAS, C.; PICCIRILLO, E. M.; ROISENBERG, A. \& STOLFA, D. - 1986 Petrogenetic aspects of acid and basalt lavas from the Parana plateau (Brazil): geological, mineralogical and petrochemical relationships. J. Petrol., 27:915-944.

BESOAIN, E. - 1985 - Mineralogía de arcillas de suelos. Instituto Interamericano de Cooperación para la Agricultura. San José, Costa Rica.

BIGARELLA, J.J.; MOUSINHO, R. \& SILVA, J.X. - 1965 - Pediplanos, pedimentos e seus depósitos correlativos no Brasil. Bol. Paranaense de Geografia, 16-17:117-151.

BIGARELLA, J.J. \& MAZUCHOWSKI, J.Z. - 1985 - Visão integrada da problemática da erosão. III Simpósio Nacional de Controle de Erosão. Maringá, ABGE, ADEA, 332p. 
BIGARELLA, J. J.; BECKER, R. D. \& SANTOS, G. F. - 1994 - Estruturas e origens das paisagens tropicais e subtropicais. Florianópolis, Ed. UFSC, 425 p.

BLATT, H -1967 - Original characteristics of clastic quartz grains. J. Sed. Petrol., 37:401424.

BOCQUIER, G. - 1972 - Genése et évolution de deux toposequénces de sols tropicaux đu Tchad, Mém. ORSTOM, $\mathrm{n}^{\circ} 62$.

BOKMAN, J. - 1952 - Clastic quartz particles as indices of provenance. J. Sed Petrol., 22:17-24.

BOULET, R. - 1974 - Toposequences de sols tropicaux en Haute Volta. Équilibre et déséquilibre pédobioclimatique. Universidade de Estrasburgo, Mém. ORSTOM, $n^{\circ} 85$, $272 \mathrm{p}$.

BOULET, R. -1978 - Étude pédologique des parcelies d'érsion INRA-CTFT. Centre ORSTOM de Cayenne, relatório, $9 p$.

BOULET, R.; CHAUVEL, A.; HUMBEL, F. X. \& LUCAS, Y. - 1982a - Analyse structurale et cartographie en pédologie. 1 - Prise en compte de l'organization bidimensionelle de la couverture pédologique: les études de toposséquence et leurs principaux apports a la connaissance des sols. Cah. ORSTOM, ser. Pédol., 19(4):309-322.

BOULET, R.; HUMBEL, F. X.; \& LUCAS, Y. - 1982b - Analyse structurale et cartographie en pédologie. II - un méthode d'analyse prenant en compte l'organisation tridimensionelle des couvertures pédologiques. Cah. ORSTOM, sér. Pédol., 19(4):323339.

BOULET, R.; HUMBEL, F. X. \& LUCAS, Y. - 1982C - Analyse structurale et cartographie en pédologie. III - passage de la phase analytique à une cartogrphie génerale synthétique. Cah. ORSTOM, sér. Pédol., 19(4):341-351.

BOULET, R. - 1988 - Análise estrutural da cobertura pedológica e cartografia. In: CONGRESSO BRASILEIRO DE CIENNCIAS DO SOLO, 21, Anais... Campinas, SBCS, p. $79-90$.

BOULET, R. - 1992 - Uma evolução recente da pedologia e suas implicações no conhecimento da genêse do relevo. In: CONGRESSO DA ASSOCIAÇÃO BRASILEIRA DE ESTUDOS DO QUARTENÁRIO, 3, Belo Horizonte: ABEQUAS.

BOULET, R.; LUCAS, Y., FRITSCH, E. \& PAQUET, H. - 1993 - Géochimie des paysages: le rôle des couvertures pédologiques. Coll. Sédimentologie et Géochimie de la Surface à la mémoire de Georges MILLOT, p. 55-76.

BREWER, R. - 1964 - Fabric and mineral analysis of soils. Robert e Krieger Publs. Co. Hungston. N. York, 482p.

BRINDLEY, G. W. \& BROWN, G. - 1980 - Crystal structures of clay minerals and their Xray identification. London Mineralogical Society, $495 \mathrm{p}$.

BUOL, S. W.; HOLE, F. D. \& MCCRAKEN, R. J. - 1973 - Soil genesis and classification. Ames, lowa University Press, 1973.

CAMPOS, J. O.; BLAKE, E. H. T. \& ROMANO, O. - 1982 - Arenitos do Caiuá - notas sobre ocorrências. Geociências, 1:29-47. 
CAMPY, M. \& MACAIRE, J. J. - 1989 - Geologie des formations superficielles. Paris, Masson, $433 p$.

CARVALHO, A. - 1976 - Solos da região de Marília - relações entre a pedogênese e a evolução do relevo. São Paulo, IG-USP, 163p. (Tese de Doutorado).

CARVER, R. E. - 1971 - Heavy-mineral separation. In: Procedures in Sedimentary Petrology. Edited by Robert E. Carbver, University of Georgia-EUA. 652p.

CASTRO, S. S. -1989 - Sistemas de transformação pedológica em Marilia, SP: B latossólicas e B texturais. USP-FFLCH, Departamento de Geografia, São Paulo, 274 p. (Tese de Doutorado).

CASTRO, S. S. \& CURM!, P. -1987 - Bandas onduladas em solos podzólicos - variação Marília: estruturas de transformação pedológica. Campinas, In: CONGRESSO BRASILEIRO DE CIENCIAS DO SOLO, 15, Campinas, Resumo e Cuminicação.

CHAPPELL, J. - 1967 - Recognizing fossil strand lines from grain-size analyses. J. Sed. Petrol., 37(1):157-165.

CHESTER, R. \& GREEN, R. N. -1968 - The infra-red determination of quartz in sediments and sedimentary rocks. Chem. Geol., 3:199-212.

CLAPPERTON, C. M. - 1993 - Nature of environmental changes in the South America at the Glacial Maximum. Palaeogeography, Palaeoclimatology, Palaeoecology, 101:189208.

COIMBRA, A. M -1976 - Arenitos da Formação Bauru: estudos de área fonte. Instituto de Geociências da Universidade de São Paulo. São Paulo, 2 v.,125 p. (Dissertação de Mestrado).

COMIN-CHIARAMONTI, P.; GOMES, C. B.; PICCIRILLO, E. M. \& RIVALENTI, G. - 1983High $\mathrm{TiO}_{2}$ dikes in the coastline of São Paulo and Rio de Janeiro States (Brazil). Neus Jahr. Miner. Abh. 146:133-150.

CORWIN, C.; FODOR, R. V. \& ROISENBERG, A. - 1986 - Silicate-phase compositions in the Serra Geral (Paraná) continental flood-basalt province, sothern Brazil. N. Jb. Miner., 154:57-73.

COSTA, A. C. S. - 1996 - Iron oxide mineralogy of soils derived from volcanic rocks in the Paraná river basin, Brazil. The Ohio State University, 243 p. (PhD).

COTTAS, L. R. \& BARCELOS, J. H. - 1981 - Novas considerações sobre a região de Itaqueri, São Paulo. In: SIMPÓSIO REGIONAL DE GEOLOGIA, Curitiba, SBG, 2: 7076.

CRONAN, C. S. - 1972 - Skewness and kurtosis in polymodal sediments from the Irish sea. J. Sed. Petrol., 42(1):102-107.

CUNHA, J. E.; GUMIERO, G. D.; MARQUES, E. E.; SAGUTI, L. Y. - 1990 - Urbanização e degradação do quadro Natural, área da cidade de Umuarama, PR., $8^{\circ}$ Encontro Nacional de Geógrafos, Salvador, Resumos... AGB, 39p.

CUNHA, J. E. - 1996 - Caracterização morfológica (macro e micro) e comportamento físicohídrico de duas toposseqüências em Umuarama (PR): subsidios para avaliação dos processos erosivos. USP.FFLCH, Departamento de Geografia, São Paulo, 130 p. 
(Dissertação de Mestrado).

CUNHA, J. E. \& CASTRO, S. S. - 1998 - Morfphologie, comportement physico-hídrique et l'érosion de deux sistèmes pédologiques du nord-ouest du Paraná (brésil). 16 CONGRES MONDIAL DE SCIENCE DU SOL, Le Corum, Symposium 30, Montpellier, France (CD-Room).

CUNHA, J. E. \& NÓBREGA, M. T. - 1998 - Estudo morfopedológico da toposseqüência Câmpus do Arenito de Cidade Gaúcha-PR. Santa Catarina, Geosul, 14(27):462-464. Revista do Departamento de Geociências/Universidade Federal - CFCH., (Ediçäo Especial).

CURI, N.; LIMA. P. C. \& LEPSCH, I. F. - 1985 - Terminologia de micromorfologia do solo. SOCIEDADE BRASILEIRA DE CIENCIA DO SOLO. Campinas. 33-43.

DOEGLAS, D. J. - 1968 - Grain-size indeces, classification and environments. Sedimentology, 10(1):83-100.

DEHIRA, L. K.; BRAGA, O. T.; PONÇANO, W. L.; GIMENEZ FILHO, A.; PIRES NETO, A. G.; RICOMINI, C. \& MELO, M. S. - 1981 - Sedimentos cenozóicos na região de Paranavai-Cianorte (PR). Curitiba, Atas, $3^{\circ}$ Simp. Reg. Geol., SBG, 2:14-24.

DELVIGNE, J. - 1965 - Pédogénese en zone tropicale: la formation des minéraux secondaires en milieu ferralitique. Publ. Mém. ORSTOM, $n^{\circ} 13,177 \mathrm{p}$.

DRYDEN, L. \& DRYDEN, C. - 1946 - Comparative rates of weatering of some common heavy minerals. J. Sed. Petrol., 16:91-96.

DUANE, D. B. - 1964 - Significance of skewness in recent sediments, Western Pimlico Sound, North Carolina. J. Sed. Petrol., 34(4):864-874.

EMPRESA BRASILEIRA DE PESQUISA AGROPECUÁRIA. SERVIÇO NACIONAL DE LEVANTAMENTO E CONSERVAÇÃO DO SOLO. INSTITUTO AGRONOOMICO DO PARANÁ - 1984 - Levantamento de reconhecimento dos solos do estado do Paraná. Vol. 1 e 2, $791 \mathrm{p}$.

FARMER, V. C. \& PALMIERI, F. - 1975 - The characterization of soil minerals by infrared spectroscopy. In: GIESEKING, E. J. ed. Soil Components. Berlin, Springer Verlag, Vol. 2, p. 573-670.

FARMER, V. C. \& RUSSEL, J. D. - 1964 - Infrared absorption spectrometry in clay studies. Clay Clay Miner. (15):121-142.

FERNANDES, L. A. - 1992 - A cobertura cretácea suprabasáltica no Paraná e Pontal do Paranapanema (SP): os Grupos Bauru e Caiuá. USP-Instituto de Geociências, São Paulo, 129 p. (Dissertação de Mestrado).

FERNANDES, L. A.; COIMBRA, A. M.; BRAND NETO, M. e GESICKI, A. L. D. - 1994 Argilominerais do Grupu Caiuá. R. Bras. Geoc. 24(2):90-96.

FILIZOLA, H. F. 1993 - O papel da erosão geoquímica na evolução do modelado da bacia de Taubaté - SP. Departamento de Geografia -FFLCH - USP., São Paulo, 2 volumes. (Tese de Doutorado).

FODOR, R. V.; CORWIN, C. \& ROISENBERG, A. - 1985 - Petrology of Serra Geral (Paraná) continental flood basalts, southern Brazil: crustal contamination, source 
material, and South Atlantic magmatism. Contrib. Mineral. Petrol. 91:4-65.

FODOR, P. V. - 1987 - Low and high $\mathrm{TiO}_{2}$ flood basalts of southern Brazil: Origin from picritic parentage and a common mantle source. Earth Planet. Sci. Letters 84:423 -430.

FOLK, R. L. - 1954 - The distinction between grain-size and mineral composition in sedimentary rock nomenclature. J. Geol., 62(4):344-359.

FOLK, R. L \& WARD, W. C. - 1957 - Brazos River bar, a study in the significance of grainsize parameters. J. Sed. Petrol., 27(1):2-26.

FREITAS, R. O. - 1973 - Geologia e petrologia da Formação Caiuá no estado de São Paulo. Bol. Inst. Geogr. Geol., 50:122 p.

FRIEDMANN, G. M. - 1961 - Distinction between dune, beach and river sands from their textural characteristics. J. Sed. Petrol., 31(2):514-529.

FRIPIAT, J. J. - 1960 - Application de la spectrocopie infrarouge à l'étude des mineraux argileux. Bull. Groupe Fr. Argiles, 12(7):25-41.

FRITSCH, E. - 1988 - Morphologie des quartz d'une couverture ferrallitique dégradée par hydromorphie. Cah. ORSTOM, sér. Pédol., 24(1):3-15.

FULFARO, V. J. \& PERINOTTO, J. A. J. - 1996 - A bacia Bauru: estado da arte. In: SIMPÓSIO SOBRE O CRETÁCEO DO BRASIL, 4. Rio Claro, 1996. Boletim...Rio Claro, UNESP-SP.

GADSDEN, J. A. - 1975 - Infrared spectra of minerals and related inorganic compounds. $277 \mathrm{p}$.

GALEHOUSE, J. S. - 1971 - Sedimentation analysis, In: Carver ed.: Procedures in sedimentary petrology. Wiley-Interscience; John Wiley \& Sons, (Inc.): New York, p.69. 94.

GASPARETTO, N. V. L. - 1991 - Alteração intempérica de rochas vulcânicas ácidas na região central do estado do Rio Grande do Sul. Instituto de Geociências, UFRGS, Porto Alegre, 119 p. (Dissertação de Mestrado).

GASPARETTO, N.V.L.; NAKASHIMA, P. \& NÓBREGA, M.T. - 1993 - Mapeamento geotécnico de Umuarama - Carta de solos - Carta de riscos. Maringá, UEM-DGE, 36p. (Notícia Explicativa - Inédito).

GIANNINI, P. C. F. - 1987 - Sedimentação quaternária na planicie costeira de PeruibeItanhaem (SP). IG-USP, São Paulo, 2 vol. 234 p. (Dissertação de Mestrado).

GORDON Jr., M. - 1947 - Classification of the gondwanic rocks of Paraná, Santa Catarina and Rio Grande do Sul. D.N.P.M., Div. Geol. Min. Pr. e Est., n 38 , pp. 1-19.

GRIFFITHS, J. C. - 1967 - Scientific method in analysis of sediments: McGraw-Hill Book Co., New York, $508 \mathrm{p}$.

GRIM, R. E. - 1968 - Clay mineralogy. 2 ed., McGraw Hill Co. Inc., New York, 596 p.

INSTITUTO AGRONÓMICO DO PARANÁ, Londrina, PR. - 1994 - Cartas climáticas do estado do Paraná. Londrina, IAPAR, $49 \mathrm{p}$. ilustrado (Documento $\mathrm{n}^{\circ} .18$ ).

JABUR, I. C. \& SANTOS, M. L. - 1984 - Revisão estratigráfica da Formação Caiuá. Maringá (PR), Bol. Geogr., 2(2):91-106. 
JABUR, I. - 1992 - Analise paleoambiental do Quaternário superior na bacia do alto Paraná. Instituto de Geociências e Ciências Exatas - UNESP - Rio Claro - SP. 184 p. (Tese de Doutorado).

JACKSON, M. L. - 1964 - Chemical composition of soils. In: Bear, F.E. (ed.) Chemistry of the soil. $2^{\text {a }}$. ed., Reinhold Publ. Co., New York, 71-141p.

JUSTUS, J. O. - 1985 - Subsidios para interpretação morfogenética através da utilização de imagens de radar. Universidade Federal da Bahia, Salvador, 204 p. (Dissertação de Mestrado).

KÄMPF, N. - 1995 - Haloisitas em saprólitos de rochas vuicânicas do Rio Grande do Sul. R. Bras. Ci. Solo, Campinas, 19:179-184.

KÄMPF, N.; AZEVEDO, A. C. \& COSTA JR, M. I. - 1995 - Estrutura básica de argilominerais 2:1 com hidróxi-Al entrecamadas em latossolo bruno do Rio Grande do Sul. R. Bras. Ci. Solo, Campinas, 19:185-190.

KING, L.C. - 1956 - A geomorfologia do Brasil oriental. R. Bras. Geog. ano XVIII, 2: 147265.

KOLDIJK, W. S. - 1968 - On environment-sensitive grain-size parameters. Sedimentology, 10(1):57-69.

KRYNINE, P. D. - 1937 - Petrology and genesis of the Siwalik Series. Am. J. Sci., 34:422446.

KRUMBIEN, W. C. - 1941 - Measurement and geologic significance of shape and roundness of sedimentary particles. J. Sed. Petrol., 11:64-72.

LANDIM, P. M. B. \& FÚLFARO, V. J. - 1971 - Nota sobre a gênese da Formação Caiuá. In: CONGRESSO BRASILEIRO DE GEOLOGIA, 25. São Paulo, Anais..., São Paulo, SBG, v. 2:277-280.

LANDIM, P. M. B. \& SOARES, P. C. - 1976 - Estratigrafia da Formação Caiuá. In: CONGRESSO BRASILEIRO DE GEOLOGIA, 29, Ouro Preto, Anais... Ouro Preto, SBG, v. 2, p. 195-206.

LEDRU, M. P. - 1993 - Late quaternary environmental and climatic changes in Central Brazil. Quaternary Research, 39:90-98.

LEPRUN, J. C. - 1979 - Les cuirassesferrgineusesdes pays cristallins d'Afrique Occidentale sèche. Genèse, transformations, dégradations. Thèse Sci. Strasbourg et Sci. Géol., Mém., Strasbourg, 58, 224p.

LUCAS, Y. - 1989 - Systèmes pédologiques en Amazonie brésilienne. Equilibre. Déséquilibre et transformations. Thèse Sci. Poitiers, $157 \mathrm{p}$.

MAACK, R. - 1941 - Algumas observações a respeito da existência do Arenito São Bento e Caiuá no estado do Paraná. Arq. Mus. Paraná, 1:107-129.

MAACK, R. - 1953 - As conseqüências da devastação das matas no estado do Paraná. Arq. Bol. Técn., 8:459-472.

MARTINS, L. R. - 1967 - Aspectos texturais e deposicionais dos sedimentos praiais e eólicos da planície costeira do Rio Grande do Sul. Porto Alegre, Esc. Geol., Publ. Esp. $n^{\circ} 13, \mathrm{pp} .1-102$. 
MARTINS, V. M. - 1994 - Estudo de uma toposseqüência de solos no munícipio de Cidade Gaúcha - PR. Dept. Geografia - UEM., Maringá, 46 p. (Trabalho de Iniciação CientíficaInédito).

MARTINS, V. M.; CASTRO, S. S.; CUNHA, J. E.; NÓBREGA, M. T. \& GASPARETTO, N. V. L. - 1998 - Relação entre o modelado e a cobertura pedológica na vertente direita do córrego Bom Jesus em Cidade Gaúcha-PR. Santa Catarina, Geosul, 14(27):511-514. revista do Departamento de Geociências/Universidade Federal - CFCH., (Edição Especial).

MCFARLANE, M. J. \& BOWDEN, D. J. - 1992 - Mobilization of alumunium in weathering profiles of the african surface in Malawi. Earth Surface Processes and Landform, V.17, 789-805.

MELO, M. S.; COIMBRA, A. M. \& CUHIERATO, G. - 1997 - Coberturas colúvio-eluviaisneocenozóicas do centro-leste do estado de São Paulo - redefinição da Formação Santa Rita do Passa Quatro. In: CONGRESSO DA ASSOCIAÇÃO BRASILEIRA DE ESTUDOS DO QUATERNÁRIO, 6, Curitiba, 1997. Resumos Expandidos... Curitiba, ABEQUA, p. 199-203.

MENDES, J. C. - 1984 - Elementos de estratigrafia. Ed. USP, São Paulo, 566 p.

MENEGOTTO, E. \& GASPARETTO, N. V. L. - 1987 - Intemperização de rochas vulcânicas básicas e ácidas na região de Santa Maria, RS. Porto Alegre, $1^{\circ} \mathrm{CBGq}$., vol. 2, pp.6983.

MEZZALIRA, S. \& ARRUDA, M. R. - 1965 - Observações geológicas na região do Pontal do Paranapanema, estado de São Paulo. An. Acad. Bras. Ciênc., 37(1):69-77.

MILLOT, G. - 1964 - Géologia des argiles. Masson et Cie., Paris, 499 p.

MILLOT, G.; BOCQUIER, G.; CHAUVEL, A.; LEPRUN, J. C.; NAHON, D.; PAQUET, H.; PEDRO, G.; ROGNON, P.; RUELLAN, A. \& TARDY, Y. - 1979 - Géochimie de la surface, pédogenèse, aplanissements et formes du relief dans les pays méditerranéens et tropicaux. Sci. Géol., Mém., Strasbourg, 53.

MINEROPAR. - 1986 - Mapa geológico do estado do Paraná. Curitiba, PR.

MINISTÉRIO DA AGRICULTURA - 1970 - Levantamento de reconhecimento dos solos do noroeste do Paraná. Bol. Técnico. Equipe de pedologia e fertilidade do solo, Rio de Janeiro (14):1-102.

MOIOLA, R. J. \& WEISER, D. - 1968 - Textural parameters - an evaluation. J. Sed. Petrol., 38(1)45-53.

MORAL CORDONA, J. P.; SÁNCHEZ BELLÓN, A.; LOPPEZ AGUAIO, F. \& CABALLERO, M. A. - 1996 - The analysis of quartz grain surface features as a complementary method for studying their provenance: the Guadalete river Basin (Cádiz, SW Spain).

Sedimentary Geology 106:155-164.

MORAL CORDONA, J. P.; GUTIÉRREZ MAS, J. M.; SÁNCHEZ BELLÓN, A.; LÓPEZ AGUAIO, F. \& CABALLERO, M. A. - 1997 - Provenance of multicycle quartz arenites of Pliocene age at Arcos, southwestern Spain. Sedimentary Geology 112:251-261.

MURATÓRI, A. M. - 1997 - A degradação da paisagem na região noroeste do estado do Paraná: condicionantes naturais e antrópicas. In: CONGRESSO DA ASSOCIAÇÃO 
BRASILEIRA DE ESTUDOS DO QUATERNÁRIO, 6, Curitiba, 1997. Resumos Expandidos... Curitiba, ABEQUA, p. 213-216.

NEVES, P. G. P. - 1991 - Palinologia de sedimentos de uma mata tropical paludosa em Terra de Areia, planicie costeira norte. Instituto de Geociência - UFRGS., 166 p. (Tese de Mestrado).

NÓBREGA, M.T.; GASPARETTO, N.V.L. \& NAKASHIMA, P. - 1992 - Metodologia para cartografia geotécnica de Umuarama. Maringá (PR), Bol. Geogr., 10(1):5-10.

NÓBREGA, M. T. - 1995 - Caracteristicas e mecanismo de estabilização de solos tropicais com cal e cimento em pista experimental. IG-USP, São Paulo, 247p. (Tese de Doutorado).

NORDSTROM, C. E. \& MARGOLIS - 1972 - Sedimentary history of central California Shelf Sands as revealed by scanning electron microscopy. J. Sed. Petrol., 42(3):527-536.

OLPHEN, H. \& FRIPIAT, J. J. - 1979 - Data handbook for clay materials and other nonmetallic minerals. Pergamon Press, Oxford.

PELLERIN, J. \& QUEIROZ NETO, J. P. - 1992 - Morfogênese e pedogênese no córrego da Invernada (Marília, SP). In: CONGRESSO DA ASSOCIAÇÃO BRASILEIRA DE ESTUDOS DO QUATERNÁRIO, 3, Belo Horizonte. Anais...

PETTIJOHN, F. J. -1975 - Sedimentry Rocks. Harper \& Row Publichers, New York, 731p.

PETTIJOHN, F. J. -1980 - Rocas sedimentarias. EUDEBA, Buenos Aires, 4 ed., 731p.

PICARD, M. D. - 1971 - Classification of fine grained sedimentary rocks. J. Sed. Petrol., 41(1):179-195.

PICCIRILLO, E. M.; RAPOSO, M. I. B.; MELFI, A. J.; COMIM-CHIARAMONTI, P.; BELLIENI, G.; CORDANI, U. G. \& KAWASHITA, R. - 1987 - Bimodal fissural volcanic suites from the Paraná Basin (Brazil): Rb-Ar age, Sr-isotopes and geochemistry. Geochim. Brasiliensis, 1(1):53-59.

PITTMAN, E. D. - 1972 - Diagenesis of quartz in sandstone as revealed by scanning eletron microcopy. J. Sed. Petrol., 42(3):507-519.

PONÇANO, W. L. - 1986 - Sobre a interpretação ambiental de parâmetros estatísticos granulométricos: exemplos de sedimentos quaternários da costa brasileira. R. Bras. Geol., 16(2):157-170.

POPP, J.H. \& BIGARELLA, J.J. - 1975 - Formações cenozóicas do noroeste do Paraná. Rio de Janeiro Anais Acad. Brasil. Ciênc., 47:465-472. (Suplemento).

QUEIROZ NETO, J. P. - 1988 - Análise estrutural da cobertura pedológica no Brasil. In: CONGRESSO BRASILEIRO DE CIÊNCIA DO SOLO, 21, Anais... Campinas, SBCS. p. $415-430$.

RICCOMINI, C.; GIMENEZ FILHO, A.; PIRES NETO, A. G.; STEIN, D. P.; ALMEIDA, F. F. M.; DEHIRA, L. K.; MELO, M. S.; BRAGA, T. O. \& PONÇANO, W. L. - 1981 Características da porção basal da Formação Caiuá, no noroeste do Paraná. In: SIMPÓSIO REGIONAL DE GEOLOGIA, 3, Curitiba, Atas..., Curitiba, SBG, 2:34-48.

RIEZEBOS, P. A. -1974 - Scanning electron microscopical observations on weakly cemented sands. Geol. Mijnb., 53(4):109-122. 
RITTENHOUSE, G. - 1943 - Trasportation and deposition of heavy minerals. Bull. Geol. Soc. Amer., 54:1725-1780.

ROSS, J. L. S. - 1991 - O relevo brasileiro, as superfícies de aplanamento e níveis morfológicos. 7-24.

RUEGG, N. R. - 1969 - Aspectos geoquímicos, mineralógicos e petrográficos de rochas basálticas da bacia do Paraná. FFCL/USP, São Paulo, 172 p. (Tese de Doutorado).

RUELLAN, A. \& DOSSO, M. - 1993 - Regards sur le sol. Les Éditions Foucher, Paris. $192 p$.

RUSSEL, J. D. \& FRASER, A. R. - 1994 - Infrared methods. Clay Mineralogy: Spectroscopy and Chemical Determinative Methods. Edited by Wilson, M. J. Published by Chapmam \& Hall, London, Chapter, 2.

SALOMÃO, F. X. T. -1994 - Processos erosivos lineares em Bauru (SP): regionalização cartográfica aplicada ao controle preventivo urbano e rural. USP.FFLCH, Departamento de Geografia, São Paulo, 200 p. (Tese de Doutorado).

SANFORD, R. M. \& LANGE, F. W. - 1960 - Basin study appoach for oil evaluation of Paraná miogeosycline of south Brazil. Bol. Amen. Assoc. Petrol. Geol., 44(8):13161370.

SANTOS, L. S. C. - 1995 - Estudo morfológico da toposseqüência da Posada da Esperança, em Bauru, SP: subsidio para a compreensão da gênese, evolução e comportamento atual dos solos. USP-FFLCH, São Paulo, Departamento de Geografia, USP, 71 p. (Dissertação de Mestrado).

SANTOS, M. L. - 1997 - Estratigrafia e evolução do sistema siliciclástico do rio Paraná no seu curso superior: ênfase à arquitetura dos depósitos, variação longitudinal das fácies e processos sedimentares. UFRGS - IG, Porto Alegre, Instituto de Geociências, 2 v. 250 p. (Tese de Doutorado).

SARTORI, P. L. P.; MACIEL FILHO, C. L. \& MENEGOTTO, E. - 1975 - Contribuição ao estudo das rochas vulcânicas da bacia do Paraná na região de Santa Maria, RS. An. Acad. Bras. Ci. 52:125-133.

SARTORI, P. L. P. \& GOMES, C. B. - 1980 - Composição químico-mineralógica das últimas manifestações vulcânicas na região de Santa Maria, RS. An. Acad. Bras. Ciênc. 52(1):125-133.

SCHIMITZ, P. I. - 1990 - Caçadores e coletores antigos. In: PINTO, M. N., ed.. Cerrado, características, ocupação e perspectivas. Editora da UNB, p. 101-146.

SCHWERTMANN, U. \& TAYLOR, R. M. - 1989 - Iron oxides. In: J. B. Dixon, and S. B. Weed (eds). Minerals in soil environments, 2nd Ed., Book Ser. $n^{\circ} 1$. Soil Sci Soc. Am. Madison, WI.

SHEPARD, F. P. - 1954 - Nomenclature based on sand-silt-clay rations. J. Sed. Petrol., 24(3):151-158.

SILVEIRA, H. - 1998 - Modificações resultantes da ação antrópica: uso, manejo e reflexos no meio nural do município de Cidade Gaúcha, PR. Presidente Prudente, UNESP, 96p. (Disertação de Mestrado). 
SMART, P \& TOVEY, N. K. - 1982 - Electron microscopy of soil and sediments: techniques. Ed. Oxford University Press. New York, $264 \mathrm{p}$.

SOARES, P. C.; SINELLI, O.; PENALVA, F.; WERNICK, E.; SOUZA, A. \& CASTRO, P. R. M. - 1973 - Geologia do nordeste do estado de São Paulo. In: CONGRESSO BRASILEIRO DE GEOLOGIA, 27, Aracajú. Anais..., SBG, v. 1.

SOARES, P. C.; LANDIM, P. M. B. - 1976 - Depósitos cenozóicos na região centro-sul do Brasil. Notícia Geomorfológica, 16(31):17-39.

SOARES, P. C.; LANDIM, P. M. B.; FÚLFARO, V. J. \& SOBREIRO NETO, A. F. - 1979 Ensaio de caracterização estratigráfica do cretáceo no estado de São Paulo. In: SIMPÓSIO REGIONAL DE GEOLOGIA, 2, Rio claro, Boletim de Resumos. Rio Claro, SBG/Núcleo SP.

SOARES, P. C.; LANDIM, P. M. B.; FÚLFARO, V. J. \& SOBREIRO NETO, A. F. - 1980 Ensaio de caracterização estratigráfica do cretáceo no estado de São Paulo; Grupo Bauru, R. Bras. Geoc., 10(3):177-185.

SOUZA FILHO, E. E. - 1993 - Aspectos da geologia e estratigrafia dos depósitos sedimentares do no Paraná entre Porto Primavera (MS) e Guaíra (PR). IG - USP., São Paulo, 214p. (Tese de Doutorado).

STEVAUX, J. C. - 1993 - O Paraná: geomorfogênese, sedimentação e evolução quaternária do seu curso superior (região de Porto Rico, PR). IG - USP., São Paulo, 242p. (Tese de Doutorado).

STEVAUX, J. C. - 1994 - The upper Paraná river (Brazil): geomorphology, sedimentology and paleoclimatology. Quaternary International, v. 21, p.143-161.

STOOPS, G. \& JONGERIUS, A. - 1975 - Proposal for a micrommorphological cassification in soil materiais. I. A classification of the related distribuitions of coarse and fine particles. Geoderma, 13:189-200, (a reply Geoderma, 19:247-249, 1977).

SUAREZ, J. M. - 1975 - Contribuição à geologia do extremo oeste do estado de São Paulo. Rio de Janeiro, Bol. Geogr., 34(247):128-160.

SUAREZ, J. M. - 1976 - Contribuição à geologia do extremo oeste do estado de São Paulo. Rio de Janeiro, Bol. Geogr., 34(248):119-155.

SUGUIO, K. - 1973 - Introdução à sedimentologia. São Paulo, Ed. Edgard Blücher/EDUSP. $317 p$.

SUGUIO, K. - 1980 - Fatores paleoambientais e paleoclimáticos e subdivisão estratrigráfica do Grupo Bauru. In: MESA REDONDA, "A Formação Bauru no estado de São Paulo e regiōes adjacentes", São Paulo, Coletânea de Trabalhos e Debates, Sociedade Brasileira de Geologia, Núcleo de São Paulo, p. 15-30.

SUGUIO, K.; MARTIN, L.; BITTENCOURT, C. S. P.; DOMINGUES, J. M. L. \& FLEXOR, J. M. - 1985 - Flutuações do nível relativo do mar durante o Quaternário superior ao longo do litoral brasileiro e suas implicações na sedimentação costeira. $R$. Bras. Geoc., 15(4):273-283.

SUTTNER, L. J.; BASU, A. \& MACK G. H. - 1981 - Cimate and origin of quartz arenites. J. Sed. Petrol., 51(4):1235-1246. 
THORNBURY, W. D. - 1966 - Principios de Geomorfologia. 2 ed. Buenos Aires. Editorial Kapelusz.

THOMAZ, M. F. \& THORP, M. B. - 1996 - The response of geomorphic systems to climatic and hydrological change during the late glacial and early Holocene in the humid and sub-humid tropics. In: BREANSON, J.; BROWN, A. G. \& GREGORY, K. J. (eds.). Global Continental Changes: the context of paleohydrology, Geological. Society. Special. Publication. 115, p. 139-153.

THOMAZ, S. L. - 1999 - Paleopalinologia e paleoecologia de depósitos holocênicos da planicie aluvial do alto rio Paraná na região de Porto Rico, estado do Paraná

(Brasil). Departamento de Biologia, Universidade Estadual de Maringá, 56 p. (Tese de Doutoramento).

TOMAZELLLI, J. J. - 1977 - Minerais pesados da plataforma continental do Rio Grande do Sul. IG-UFRGS, Porto Alegre, 77 p. (Dissertação de Mestrado).

TRICART, J. - 1965 - Principes et méthodes de la Géomorphologie. Paris, Masson et Cie.. $496 p$.

TROPPMAIR, H. - 1994 - Perfil fitoecológico do estado do Paraná. Bol. Geogr., Univ. Est. Maringá - PR, 8(1)67-80.

VAZ, L. F. - 1997 - Coluviões de recuo de encostas. in: CONGRESSO DA ASSOCIAÇÃO BRASILEIRA DE ESTUDOS DO QUATERNÁRIO, 6, Curitiba, 1997. Resumos Expandidos... Curitiba, ABEQUA, p. 274-277.

VERBEKE, R. - 1969 - Sur un procédé de fabrication de lames minces dans roches peu cimentées et des sols. Bull. de la Soc. Géol. France, 7 Tomo XI, (3):426-433.

YOUNG, A. - 1976 - Tropical soils and soil survey. Cambridge University Press, Cambridge, $468 \mathrm{p}$.

WAUGH, B. - 1970 - Formation of quartz overgrowts in the Penrith Sandstone (lower permian) of Northwest England as revealed by scanning electron microscopy. Sedimentology, 14:209-320.

WASHBURNE, C. W. - 1930 - Petroleum geology of the State of São Paulo. Bol. da Comissão Geográfica e Geológica do Estado de São Paulo, 22:1-272.

WHITE, I. C. - 1908 - Relatório final da comissão de estudos das minas de carvão de pedra do Brasil. Relatório sobre "coal measures" e rochas associadas do Sul do Brasil. Parte I, Geologia, 201 p.

WHITE, J. L. \& ROTH, C. - 1986 - Infrared spectrometry. In: KLUTE, A. ed. Methods of Soil Analysis. Part. 1. Physical and Mineralogical Methods. $2^{\text {nd }}$ Ed., Madison, American Society of Agronomy - Soil Science Society of America. p. 291-330 (Monograph n. 9). 
ANEXOS 
ANEXO 1

Dados climáticos das áreas de estudo 
Dados climáticos da Microrregiảo de Cianorte - Paraná

Valores médios mensais - 1972 a 1993

Fonte IAPAR (1994) - Londrina - PR

\begin{tabular}{|c|c|c|c|c|c|c|c|}
\hline \multicolumn{7}{|c|}{ TEMPERATURA ${ }^{\circ} \mathrm{C}$} & \multirow{2}{*}{$\frac{\text { Precipitaçåo }}{\mathrm{mm}}$} \\
\hline Mês & $\begin{array}{c}\text { Média } \\
\text { Máxima }\end{array}$ & $\begin{array}{l}\text { Média } \\
\text { Minima }\end{array}$ & $\begin{array}{l}\text { Máxima } \\
\text { Absoluta }\end{array}$ & $\begin{array}{l}\text { Minima } \\
\text { Absoluta }\end{array}$ & $\begin{array}{c}\text { Média } \\
\text { Compensada }\end{array}$ & $\begin{array}{l}\text { Amplitude } \\
\text { Térmica }\end{array}$ & \\
\hline Janeiro & 30,2 & 20,4 & 35,9 & 11,3 & 24,6 & 24,6 & 194,4 \\
\hline Fevereiro & 30,2 & 20,4 & 36,4 & 13,0 & 24,6 & 23,4 & 150,2 \\
\hline Março & 30,0 & 19,8 & 35,4 & 8,8 & 24,1 & 26,6 & 135,3 \\
\hline Abril & 27,8 & 17,7 & 33,4 & 7,3 & 22,0 & 26,1 & 156,6 \\
\hline Maio & 24,6 & 15,0 & 32,0 & 2,2 & 19,1 & 29,8 & 146,6 \\
\hline Junho & 23,0 & 13,3 & 29,6 & 1,8 & 17,4 & 27,8 & 102,0 \\
\hline Julno & 23,5 & 12,9 & 31,2 & $-2,4$ & 17,3 & 33,6 & 72,8 \\
\hline Agosto & 25,1 & 14,3 & 33,6 & 1,0 & 18,9 & 32,6 & 81,7 \\
\hline Setembro & 25,8 & 15,4 & 37,4 & 3,2 & 20,0 & 34,2 & 135,0 \\
\hline Outubro & 28,3 & 17,5 & 35,5 & 7,9 & 22,4 & 27,6 & 158,1 \\
\hline Novembro & 29,5 & 18,8 & 39,0 & 9,4 & 23,7 & 29,6 & 142,6 \\
\hline Dezembro & 29,7 & 19,9 & 38,0 & 11,9 & 24 & 26,1 & 211,4 \\
\hline MÉDIA & 27,3 & $\uparrow 7,1$ & & & 21,5 & & \\
\hline
\end{tabular}


Dados climáticos da Microrregião de Paranavaí - Paraná

Valores médios mensais - 1972 a 1993

Fonte IAPAR (19940 - Londrina - PR

\begin{tabular}{|c|c|c|c|c|c|c|c|}
\hline \multicolumn{7}{|c|}{ TEMPERATURA ${ }^{\circ} \mathrm{C}$} & \multirow{2}{*}{$\frac{\text { Precipitação }}{\mathrm{mm}}$} \\
\hline Mês & $\begin{array}{l}\text { Média } \\
\text { Máxima }\end{array}$ & $\begin{array}{l}\text { Média } \\
\text { Mínima }\end{array}$ & $\begin{array}{l}\text { Máxima } \\
\text { Absoluta }\end{array}$ & $\begin{array}{l}\text { Minima } \\
\text { Absoluta }\end{array}$ & $\begin{array}{c}\text { Média } \\
\text { Compensada }\end{array}$ & $\begin{array}{l}\text { Amplitude } \\
\text { Térmica }\end{array}$ & \\
\hline Janeiro & 31,4 & 20,8 & 37,4 & 11,5 & 25,2 & 25,9 & 171,2 \\
\hline Fevereiro & 31,1 & 20,7 & 37,6 & 13,0 & 24,8 & 24,6 & 147,1 \\
\hline Março & 30,8 & 20,2 & 36,3 & 8,4 & 24,5 & 27,9 & 128,2 \\
\hline Abril & 28,7 & 18,0 & 35,4 & 7,5 & 22,3 & 27,9 & 108,8 \\
\hline Maio & 25,6 & 15,5 & 31,9 & 2,4 & 19,5 & 29,5 & 125,7 \\
\hline Junho & 24,1 & 13,8 & 30,8 & 1,2 & 17,9 & 29,6 & 97,6 \\
\hline Julho & 24,5 & 13,4 & 32,0 & $-3,0$ & 17,9 & 35,0 & 58,9 \\
\hline Agosto & 26,4 & 14,9 & 34,3 & 0,0 & 19,6 & 34,3 & 57,7 \\
\hline Setembro & 26,6 & 15,8 & 38,3 & 4,2 & 20,4 & 34,1 & 133,3 \\
\hline Outubro & 29,3 & 18,0 & 37,7 & 8,6 & 22,9 & 29,1 & 155,5 \\
\hline Novembro & 30,5 & 19,4 & 41,5 & 10,0 & 24,1 & 31,5 & 125,6 \\
\hline Dezembro & 30,6 & 20,3 & 40,0 & 14,1 & 24,7 & 25,9 & 179,9 \\
\hline MÉDIA & 28,3 & 17,6 & & & 22,0 & & \\
\hline
\end{tabular}


Dados climáticos da Microrregião de Umuarama - Paraná

Valores médios mensais - 1972 a 1993

Fonte IAPAR (1994) - Londrina - PR

\begin{tabular}{|c|c|c|c|c|c|c|c|}
\hline \multicolumn{7}{|c|}{ TEMPERATURA ${ }^{\circ} \mathrm{C}$} & \multirow{2}{*}{$\frac{\text { Precipitaçăo }}{\mathrm{mm}}$} \\
\hline Mês & $\begin{array}{l}\text { Média } \\
\text { Máxima }\end{array}$ & $\begin{array}{l}\text { Média } \\
\text { Minima }\end{array}$ & $\begin{array}{l}\text { Máxima } \\
\text { Absoluta }\end{array}$ & $\begin{array}{l}\text { Minima } \\
\text { Absoluta }\end{array}$ & $\begin{array}{c}\text { Média } \\
\text { Compensada }\end{array}$ & $\begin{array}{l}\text { Amplitude } \\
\text { Térmica }\end{array}$ & \\
\hline Janeiro & 30,4 & 21,0 & 36,8 & 12,1 & 25,0 & 24,7 & 164,7 \\
\hline Fevereiro & 30,3 & 20,8 & 37,0 & 12,5 & 24,8 & 24,5 & 131,8 \\
\hline Março & 30,0 & 20,3 & 36,2 & 8,5 & 24,5 & 27,7 & 123,8 \\
\hline Abril & 27,7 & 18,0 & 34,0 & 7,4 & 22,2 & 26,6 & 134,8 \\
\hline Maio & 24,7 & 15,4 & 31,4 & 2,6 & 19,4 & 28,8 & 154,3 \\
\hline Junho & 23,3 & 13,8 & 30,4 & 2,2 & 17,8 & 28,2 & 104,7 \\
\hline Julho & 23,6 & 13,4 & 31,2 & $-1,4$ & 17,7 & 32,6 & 72,8 \\
\hline Agosto & 25,0 & 14,7 & 34,1 & 0,5 & 19,2 & 33,6 & 81,7 \\
\hline Setembro & 25,7 & 15,8 & 38,3 & 3,2 & 20,2 & 35,1 & 139,4 \\
\hline Outubro & 28,0 & 17,9 & 36,0 & 8,2 & 22,6 & 27,8 & 152,2 \\
\hline Novembro & 29,3 & 19,3 & 39,2 & 9,5 & 23,9 & 29,7 & 165,4 \\
\hline Dezembro & 29,8 & 20,4 & 38,4 & 13,2 & 24,6 & 25,2 & 190,0 \\
\hline MÉDIA & 27,3 & 17,6 & & & 21,8 & & \\
\hline
\end{tabular}




\section{ANEXO 2}

Síntese das descrições macro e micromorfológicas 
Toposseqüência do sítio Três Leões 
Quadro sintese das descriçőes morfológicas dos perfis de solos das trincheiras da topossequeencia sitio Três Leōes - Cianorte

\begin{tabular}{|c|c|c|c|c|c|c|c|c|c|}
\hline TR & $\begin{array}{l}\text { PROF. } \\
\text { (cm) }\end{array}$ & COR & TEXTURA & ESTRUTURA & CONSISTÉNCIA & POROSIDADE & $\begin{array}{c}\text { RAIZES EIOU } \\
\text { ATIVIDADE BIOLÓGICA }\end{array}$ & TRANSIÇĀO & OBSERVAÇŌES \\
\hline \multirow{5}{*}{ TR I } & $0-20$ & $2,5 Y R 3 / 6$ & $\begin{array}{l}\text { franco- } \\
\text { arenosa } \\
\end{array}$ & $\begin{array}{c}\text { maciça, } \\
\text { grấos soltos }\end{array}$ & $\begin{array}{c}\text { nảo plástica e não } \\
\text { pegajosa }\end{array}$ & empithamento simples & $\begin{array}{l}\text { poucas raizes, pouca } \\
\text { atividade biológica }\end{array}$ & $\begin{array}{c}\text { clara a } \\
\text { ondulada }\end{array}$ & $\begin{array}{c}\text { muito friável, pequenos frag. de carväo vegeta } \\
\text { manchas de areia lavada }\end{array}$ \\
\hline & $20-32$ & $2,5 Y R 4 / 6$ & $\begin{array}{l}\text { franco - } \\
\text { arenosa }\end{array}$ & $\begin{array}{c}\text { maciça se desfaz em } \\
\text { microagregados }\end{array}$ & $\begin{array}{l}\text { não plástica e năo } \\
\text { pegajosa }\end{array}$ & $\begin{array}{l}\text { empilhamento simples, } \\
\text { macroporos abundantes }\end{array}$ & $\begin{array}{c}\text { poucas ralzes, pouca } \\
\text { atividade biotógica }\end{array}$ & ondulada & $\begin{array}{l}\text { muito friável, frag. de carvão, areia lavada } \\
\text { preenchendo canais de antigas raizes }\end{array}$ \\
\hline & $32-60$ & $2,5 Y R 4 / 8$ & $\begin{array}{l}\text { franco - } \\
\text { arenosa }\end{array}$ & $\begin{array}{c}\text { tendência a } \\
\text { subangular fraca }\end{array}$ & $\begin{array}{l}\text { ligeiramente plástica a } \\
\text { ligeiramente pegajosa }\end{array}$ & $\begin{array}{l}\text { empilhamento simples, } \\
\text { macroporos abundantes }\end{array}$ & $\begin{array}{l}\text { poucas ralzes, abundante } \\
\text { atividade biologica }\end{array}$ & $\begin{array}{l}\text { difusa a } \\
\text { ondulada }\end{array}$ & $\begin{array}{l}\text { fríavel, frag. de carvazo, nichos de insetos, arei } \\
\text { lavada nas faces estruturais e macroporos }\end{array}$ \\
\hline & $60-155$ & $\begin{array}{c}10 R 4 / 8 \\
2,5 Y R 4 / 8\end{array}$ & $\begin{array}{c}\text { franco-argilo- } \\
\text { arenosa }\end{array}$ & $\begin{array}{c}\text { blocos subangulares } \\
\text { pequenos e fracos }\end{array}$ & $\begin{array}{l}\text { ligeiramente plástica a } \\
\text { ligeiramente pegajosa }\end{array}$ & $\begin{array}{l}\text { empilhamento simples, } \\
\text { macroporos abundantes }\end{array}$ & $\begin{array}{l}\text { poucas raizes, abundante } \\
\text { atividade biologica }\end{array}$ & $\begin{array}{l}\text { difusa a } \\
\text { ondulada }\end{array}$ & $\begin{array}{c}\text { friável, frag. de carvão, areia lavada } \\
\text { preenchendo canais de antigas raizes e faces } \\
\text { estruturais }\end{array}$ \\
\hline & $155-200+$ & $\begin{array}{c}10 R 4 / 6 \\
2,5 Y R 4 / 8\end{array}$ & $\begin{array}{c}\text { franco-argilo- } \\
\text { arenosa }\end{array}$ & $\begin{array}{c}\text { maciça se desfaz em } \\
\text { microagregados }\end{array}$ & $\begin{array}{l}\text { ligeiramente plástica a } \\
\text { ligeiramente pegajosa }\end{array}$ & $\begin{array}{l}\text { empilhamento simples, } \\
\text { diminui macroporos }\end{array}$ & $\begin{array}{c}\text { poucas raizes, pouca } \\
\text { atividade bilógica }\end{array}$ & - & $\begin{array}{c}\text { muito friável, frag. de carvăo, pequena presenç } \\
\text { de areia lavada }\end{array}$ \\
\hline \multirow{5}{*}{ TRII } & $0-18$ & $2,5 Y R 3 / 6$ & areia-franca & $\begin{array}{l}\text { maciça, } \\
\text { gråos soltos }\end{array}$ & $\begin{array}{l}\text { não plástica e năo } \\
\text { pegajosa }\end{array}$ & empithamento simples & $\begin{array}{c}\text { poucas ralizes, pouca } \\
\text { atividade biológica }\end{array}$ & $\begin{array}{c}\text { gradual } \\
\text { ondulada }\end{array}$ & $\begin{array}{c}\text { muito friável, frag. de carvăo, concentraçăo de } \\
\text { areia lavada nos macroporos }\end{array}$ \\
\hline & $18 \cdot 35$ & $2,5 Y R 4 / 6$ & areia-franca & $\begin{array}{c}\text { maciça, } \\
\text { gräos soltos }\end{array}$ & $\begin{array}{l}\text { năo plástica e nảo } \\
\text { pegajosa }\end{array}$ & $\begin{array}{l}\text { empilhamento simples, } \\
\text { macroporos abundantes }\end{array}$ & $\begin{array}{l}\text { poucas ralzes, pouca } \\
\text { atividade biologica }\end{array}$ & abrupta & $\begin{array}{l}\text { friável, bandas incipientes, frag. carvăo, areia } \\
\text { lavada preenchendo macroporos nichos/inseto }\end{array}$ \\
\hline & $35-120$ & $\begin{array}{c}10 R 4 / 8 \\
2,5 Y R 4 / 8 \\
\end{array}$ & $\begin{array}{c}\text { franco-argilo- } \\
\text { arenosa }\end{array}$ & $\begin{array}{c}\text { subangular a angular } \\
\text { média a moderada }\end{array}$ & \begin{tabular}{|l|} 
ligeiramente plástica a \\
ligeiramente pegajosa
\end{tabular} & $\begin{array}{l}\text { empilhamento simples, } \\
\text { macroporos abundantes }\end{array}$ & $\begin{array}{l}\text { poucas raizes, pouca } \\
\text { atividade biologica }\end{array}$ & $\begin{array}{c}\text { difusa } \\
\text { ondulada }\end{array}$ & $\begin{array}{l}\text { areia lavada revestindo canais de antigas raize } \\
\text { nichos de insetos e cerosidade incipiente }\end{array}$ \\
\hline & $120-150$ & $\begin{array}{c}10 R 4 / 6 \\
2,5 Y R 4 / 6\end{array}$ & $\begin{array}{c}\text { franco-argito- } \\
\text { arenosa }\end{array}$ & $\begin{array}{c}\text { subangular a angular } \\
\text { pequena fraca }\end{array}$ & $\begin{array}{l}\text { ligeiramente plástica a } \\
\text { ligeiramente pegajosa }\end{array}$ & $\begin{array}{l}\text { empithamento simples, } \\
\text { macroporos abundantes }\end{array}$ & $\begin{array}{l}\text { poucas raízes, pouca } \\
\text { atividade biológica }\end{array}$ & $\begin{array}{l}\text { difusa } \\
\text { ondulada }\end{array}$ & $\begin{array}{c}\text { pedotúbulos preenchidos por material escuro, } \\
\text { pequenos agregados mais endurecidos }\end{array}$ \\
\hline & $150-200+$ & $2.5 Y R$ R/8 & $\begin{array}{c}\text { franco-argilo- } \\
\text { arenosa }\end{array}$ & $\begin{array}{c}\text { maciça se desfaz em } \\
\text { mictoagregados }\end{array}$ & $\begin{array}{l}\text { năo plástica e năo } \\
\text { pegajosa }\end{array}$ & $\begin{array}{l}\text { empithamento simples, } \\
\text { macroporos abundantes }\end{array}$ & $\begin{array}{l}\text { poucas ralzes, pouca } \\
\text { atividade biologica }\end{array}$ & - & $\begin{array}{l}\text { muito friável, areia lavada preenchendo bolsర̄e } \\
(3 \mathrm{~cm}) \text {, canais preenchidos por material escuro }\end{array}$ \\
\hline \multirow{5}{*}{ TRIII } & $0-20$ & 5YR $4 / 4$ & areia-franca & $\begin{array}{c}\text { subangular pequena } \\
\text { fraca }\end{array}$ & $\begin{array}{l}\text { não plástica e năo } \\
\text { pegajosa }\end{array}$ & $\begin{array}{l}\text { empilhamento simples, } \\
\text { macroporos abundantes }\end{array}$ & $\begin{array}{l}\text { poucas raizes, pouca } \\
\text { atividade biologica }\end{array}$ & $\begin{array}{c}\text { clara } \\
\text { ondulada }\end{array}$ & $\begin{array}{l}\text { friável, pequenos bolsóes de areia lavada, frag } \\
\text { de canăăo, pequenos agregados argilosos duro }\end{array}$ \\
\hline & $20-45$ & \begin{tabular}{|c|}
$5 Y R 5 / 4$ a \\
$5 / 6$
\end{tabular} & areia-franca & $\begin{array}{c}\text { maciça, } \\
\text { grảos soltos }\end{array}$ & $\begin{array}{c}\text { năo plástica e năo } \\
\text { pegajosa }\end{array}$ & $\begin{array}{l}\text { empilhamento simples, } \\
\text { macroporos abundantes }\end{array}$ & $\begin{array}{c}\text { ausencia de raizes, pouca } \\
\text { atividade biologica } \\
\end{array}$ & $\begin{array}{l}\text { abrupta } \\
\text { ondulada }\end{array}$ & $\begin{array}{l}\text { friável, canais preenchidos por areia lavada, } \\
\text { restos de bandas onduladas argilosas }\end{array}$ \\
\hline & $45-65$ & 2,5 YR $4 / 6$ & $\begin{array}{l}\text { franco- } \\
\text { arenosa }\end{array}$ & $\begin{array}{l}\text { maciça, } \\
\text { grăos soltos }\end{array}$ & $\begin{array}{l}\text { ligeiramente plástica a } \\
\text { ligeiramente pegajosa }\end{array}$ & $\begin{array}{l}\text { empilhamento simples, } \\
\text { macroporos abundantes }\end{array}$ & $\begin{array}{c}\text { ausência de raizes, pouca } \\
\text { atividade biologica }\end{array}$ & $\begin{array}{c}\text { abrupta } \\
\text { ondulada }\end{array}$ & $\begin{array}{l}\text { friável, presença de bandas onduladas regulare } \\
\text { com limites nítido tanto superior como inferior }\end{array}$ \\
\hline & $65-170$ & $\begin{array}{c}10 \mathrm{R} 4 / 6 \mathrm{a} \\
4 / 8\end{array}$ & $\begin{array}{c}\text { franco-argilo- } \\
\text { arenosa } \\
\end{array}$ & $\begin{array}{c}\text { subangular a angular } \\
\text { moderada forte }\end{array}$ & $\begin{array}{l}\text { plástica e } \\
\text { pegajosa }\end{array}$ & $\begin{array}{l}\text { empilhamento simples, } \\
\text { macroporos abundantes }\end{array}$ & $\begin{array}{l}\text { ausencia de raizes, pouca } \\
\text { atividade biológica }\end{array}$ & $\begin{array}{l}\text { difusa } \\
\text { plana }\end{array}$ & $\begin{array}{l}\text { cerosidade entre agregados, nichos de insetos } \\
\text { pedotübulos preenchidos por material escuro }\end{array}$ \\
\hline & $170-200+$ & 2,5 YR $4 / 8$ & $\begin{array}{c}\text { franco-argilo- } \\
\text { arenosa }\end{array}$ & $\begin{array}{c}\text { maciça, se desfaz em } \\
\text { microaoreoados }\end{array}$ & $\begin{array}{l}\text { ligeiramente plástica a } \\
\text { ligeiramente,neaaiosa }\end{array}$ & $\begin{array}{l}\text { empilhamento simples, } \\
\text { macroporos_abundantes }\end{array}$ & $\begin{array}{l}\text { ausencia de raizes, pouca } \\
\text { atividade biolócica }\end{array}$ & - & $\begin{array}{l}\text { muito friável, nichos de insetos e pedotúbulos } \\
\text { oreennchidos oor material escuro }\end{array}$ \\
\hline
\end{tabular}


Continuação do Quadro sintese

\begin{tabular}{|c|c|c|c|c|c|c|c|c|c|}
\hline TR & $\begin{array}{l}\text { PROF. } \\
(\mathrm{cm})\end{array}$ & COR & TEXTURA & ESTRUTURA & CONSISTENCIA & POROSIDADE & $\begin{array}{l}\text { RAIZES EIOU } \\
\text { ATIVIDADE BIOLOGICA }\end{array}$ & TRANSIÇAOO & OBSERVAÇÓES \\
\hline \multirow{6}{*}{ TRIV } & 0.15 & $\begin{array}{c}\text { SYR } 4 / 3 \text { a } \\
4 / 4\end{array}$ & areia-franca & $\begin{array}{l}\text { subangular } \\
\text { pequena e fraca }\end{array}$ & $\begin{array}{l}\text { nảo plástica e não } \\
\text { pegajosa }\end{array}$ & empithamento simples & $\begin{array}{l}\text { poucas raizes, pouca } \\
\text { atividade biológica }\end{array}$ & $\begin{array}{l}\text { plana } \\
\text { clara }\end{array}$ & $\begin{array}{l}\text { friável, lentes centimétricas de areia lavada, } \\
\text { presença de pequenas nodutos ferruginosos }\end{array}$ \\
\hline & $15-35$ & $5 Y R 4 / 6$ & areia-franca & $\begin{array}{l}\text { maciça, } \\
\text { grảos soltos }\end{array}$ & $\begin{array}{c}\text { năo plástica e năo } \\
\text { pegajosa }\end{array}$ & $\begin{array}{l}\text { empilhamento simples, } \\
\text { macroporos abundantes }\end{array}$ & $\begin{array}{l}\text { raizes finas abundantes, } \\
\text { pouca atividade biológica }\end{array}$ & $\begin{array}{c}\text { abrupta } \\
\text { plana }\end{array}$ & $\begin{array}{l}\text { presença de nódulos ferruginosos com } 2 \mathrm{~cm} \text { de } \\
\text { diâmetro, subangulares e nichos de insetos }\end{array}$ \\
\hline & $35-82$ & $\begin{array}{c}5 Y R 5 / 6 \text { a } \\
4 / 8\end{array}$ & $\begin{array}{c}\text { franco-argilo- } \\
\text { arenosa }\end{array}$ & $\begin{array}{c}\text { subangutar a angular } \\
\text { moderada fraca }\end{array}$ & $\begin{array}{l}\text { ligeiramente plástica a } \\
\text { ligeiramente pegajosa }\end{array}$ & $\begin{array}{l}\text { empilhamento simples, } \\
\text { macroporos abundantes }\end{array}$ & $\begin{array}{l}\text { raizes finas abundantes, } \\
\text { pouca atividade biológica }\end{array}$ & $\begin{array}{l}\text { ondulada } \\
\text { clara }\end{array}$ & $\begin{array}{l}\text { nódulos ferruginosos }(4 \mathrm{~cm}) \text {, angulares } \\
\text { subangulares }\end{array}$ \\
\hline & $82-100$ & $2,5 Y R \quad 4 / 8$ & $\begin{array}{c}\text { franco-argilo- } \\
\text { arenosa }\end{array}$ & $\begin{array}{c}\text { subangular a angular } \\
\text { moderada média }\end{array}$ & flástica e pegajosa & $\begin{array}{l}\text { empilhamento simples, } \\
\text { macroporos abundantes }\end{array}$ & $\begin{array}{l}\text { poucas raizes, pouca } \\
\text { atividade biológica }\end{array}$ & $\begin{array}{l}\text { onduiada } \\
\text { difusa }\end{array}$ & $\begin{array}{l}\text { poucos nódulos, agregados formam plaquetas } \\
\text { semelhante a estrutura laminar, cerosidade } \\
\text { entre agregados, canais de antigas ralzes com } \\
\text { principio de hidromorfia, nichos de insetos }\end{array}$ \\
\hline & $100-140$ & $\begin{array}{c}10 R 4 / 8 \text { a } \\
4 / 4\end{array}$ & $\begin{array}{c}\text { franco-argilo- } \\
\text { arenosa }\end{array}$ & $\begin{array}{l}\text { subangular fraca } \\
\text { moderada média }\end{array}$ & $\begin{array}{l}\text { ligeiramente płástica a } \\
\text { ligeiramente pegajosa }\end{array}$ & $\begin{array}{l}\text { empilhamento simples, } \\
\text { poucos macroporos }\end{array}$ & $\begin{array}{l}\text { poucas raizes finas, pouca } \\
\text { atividade biológica }\end{array}$ & $\begin{array}{c}\text { interpenetra- } \\
\text { ça }\end{array}$ & $\begin{array}{l}\text { friável, muito úmido, frag. de rocha alterada, } \\
\text { canais vazios de antigas rafizes, manchas de } \\
\text { hidromorfia e pequenos nichos de insetos }\end{array}$ \\
\hline & $140-200+$ & $\begin{array}{c}10 R 3 / 8 \text { a } \\
6 / 8\end{array}$ & $\begin{array}{c}\text { franco-siftico } \\
\text { argilosa }\end{array}$ & $\begin{array}{l}\text { Subangular fraca } \\
\text { moderada média }\end{array}$ & $\begin{array}{c}\text { não plástica e rlåo } \\
\text { pegajosa }\end{array}$ & $\begin{array}{l}\text { empithamento simples } \\
\text { poucos macroporos }\end{array}$ & $\begin{array}{l}\text { poucas raizes, pouca } \\
\text { atividade tiológica }\end{array}$ & $\begin{array}{c}\text { interpenetra- } \\
\text { çăo }\end{array}$ & $\begin{array}{c}\text { friável, muito úmido, canais vazios de antigas } \\
\text { raizes, presença de fraturas com argila e com } \\
\text { sinais de hidromorfia, rocha alterada }\end{array}$ \\
\hline \multirow{5}{*}{$T R \vee$} & $0-10$ & 5 YR $3 / 4$ & areia-franca & $\begin{array}{l}\text { maciça, } \\
\text { gráos soltos }\end{array}$ & $\begin{array}{l}\text { não plástica e năo } \\
\text { pegajosa }\end{array}$ & $\begin{array}{l}\text { empilhamento simples, } \\
\text { macroporos abundantes }\end{array}$ & $\begin{array}{l}\text { ralzes finas abundantes, } \\
\text { pouca atividade biologica }\end{array}$ & $\begin{array}{l}\text { ondulada } \\
\text { clara }\end{array}$ & $\begin{array}{c}\text { muito friável, presença de areia lavada, com } \\
\text { nódulas ferruginosos irregulares com } 2 \text { a } 3 \mathrm{~cm} \\
\text { de diametro revestidos por material escuro }\end{array}$ \\
\hline & $10-60$ & 5YR 5/4 & areia & $\begin{array}{l}\text { maciça, } \\
\text { gráos soltos }\end{array}$ & $\begin{array}{l}\text { não plástica e náo } \\
\text { pegajosa }\end{array}$ & empilhamento simples & $\begin{array}{l}\text { raizes finas abundantes, } \\
\text { abundante atividade } \\
\text { biologica }\end{array}$ & $\begin{array}{l}\text { ondulada } \\
\text { clara }\end{array}$ & $\begin{array}{c}\text { muito friável, nódulos ferruginosos irregulares } \\
\text { a } 4 \mathrm{~cm} \text { de diametro revestidos por material } \\
\text { escuro }\end{array}$ \\
\hline & $60-75$ & 5YR 5/8 & $\begin{array}{l}\text { franco- } \\
\text { arenosa }\end{array}$ & $\begin{array}{l}\text { subangular } \\
\text { pequena fraca }\end{array}$ & $\begin{array}{l}\text { ligeiramente plástica a } \\
\text { ligeiramente pegajosa }\end{array}$ & $\begin{array}{l}\text { empilhamento simples, } \\
\text { macroporos abundantes }\end{array}$ & $\begin{array}{l}\text { poutcas ralzes, pouca } \\
\text { atividade biológica }\end{array}$ & $\begin{array}{l}\text { abrupta } \\
\text { clara }\end{array}$ & $\begin{array}{c}\text { friável, raros nódulos, comum frag. de rocha } \\
\text { alterada, canais de antigas ralzes preenchiclos } \\
\text { por material argiloso, nichos de insetos }\end{array}$ \\
\hline & $75-110$ & $\begin{array}{l}\text { 10R } 4 / 6 \text { a } \\
5 Y R 7 / 4\end{array}$ & $\begin{array}{c}\text { franco-argito- } \\
\text { arenosa }\end{array}$ & $\begin{array}{l}\text { subangular pequena } \\
\text { fraca }\end{array}$ & $\begin{array}{l}\text { ligeiramente plática a } \\
\text { |ligeiramente pegajosa }\end{array}$ & $\begin{array}{l}\text { empilhamento simpies } \\
\text { macroporos abundantes }\end{array}$ & $\begin{array}{l}\text { poucas raizes, pouca } \\
\text { atividade biológica }\end{array}$ & $\begin{array}{c}\text { interpenetra- } \\
\text { çå }\end{array}$ & $\begin{array}{c}\text { friável, água fivre, comum frag. de rocha } \\
\text { alterada, com sinais de hidromorfia, cerosidade } \\
\text { incipiente entre as estratificaçbes }\end{array}$ \\
\hline & $110-140$ & $\begin{array}{c}10 R 3 / 6 \text { a } \\
6 / 4\end{array}$ & $\begin{array}{l}\text { franco- } \\
\text { arenosa }\end{array}$ & $\begin{array}{l}\text { maciça, } \\
\text { oräos soltos }\end{array}$ & $\begin{array}{c}\text { năo plástica e nắo } \\
\text { Dedaiosa }\end{array}$ & $\begin{array}{l}\text { empilhamento simples, } \\
\text { macroporos abundantes }\end{array}$ & $\begin{array}{l}\text { poucas raizes, pouca } \\
\text { atividade biolooica }\end{array}$ & $\underset{c a c}{\text { interpenetra- }}$ & $\begin{array}{l}\text { friável, água livre, frag. de rocha alterada com } \\
\text { sinais dehidromorfia e estratificacăo visivel }\end{array}$ \\
\hline
\end{tabular}


Descriç̋es micromorfológicas dos perfis das trincheiras da toposseqüẻncia do sítio Três Leð̋es -Cianorte

\begin{tabular}{|c|c|c|c|c|c|c|}
\hline \multirow{2}{*}{\multicolumn{2}{|c|}{$\begin{array}{c}\text { TRINCHEIRA } \\
\text { VOLUMES } \\
\text { PROFUNDIDADES }(\mathrm{cm}) \\
\end{array}$}} & \multicolumn{5}{|c|}{ TR I } \\
\hline & & $\begin{array}{l}\text { Franco-arenoso } \\
\quad 10-20\end{array}$ & $\begin{array}{c}\text { Franco-arenoso } \\
22-32\end{array}$ & $\begin{array}{c}\text { Franco-arenoso } \\
40-50\end{array}$ & $\begin{array}{l}\text { Franco-argilo-arenoso } \\
90-100\end{array}$ & $\begin{array}{c}\text { Franco-argilo-arenoso } \\
175-185\end{array}$ \\
\hline \multirow{3}{*}{$\begin{array}{l}\text { FUNDO } \\
\text { MATRICIAL } \\
(\%)\end{array}$} & Esqueleto & 50 & 50 & 50 & 55 & 35 \\
\hline & Plasma & 10 & 12 & 20 & 25 & 30 \\
\hline & Poros & 40 & 38 & 30 & 30 & 35 \\
\hline \multirow{8}{*}{ ESQUELETO } & Mineralogia & quartzo & quartzo & quartzo & quartzo & quartzo \\
\hline & Origem & in situ & in situ & in situ & in situ & in situ \\
\hline & Dimensão & areia fina e muito fina & areia fina e muito fina & areia fina e muito fina & areia fina e muito fina & areia fina e muito fina \\
\hline & Frequência & comum & comum & comum & comum & comum \\
\hline & Grau/Seleção & moderadamente selec. & moderadamente selec. & moderadamente selec. & moderadamente selec. & moderadamente selec. \\
\hline & Dist. base & aleatória & aleatória/agrupada & aleatória & aleatória & aleatória \\
\hline & Dist. ref. & sem & sem & sem & sem & sem \\
\hline & Orientação & não orientados & não orientados & não orientado & não orientado & não orientados \\
\hline \multirow{5}{*}{ PLASMA } & Cor & vermelho-alaranjada & vermelho-alaranjada & vermelho-fernuginoso & vermelho-escura & verm. esc. a alaranjada \\
\hline & Orientação & não orientado & sem & setores forte continua & domínios fraca continua & sem \\
\hline & Dist. base & quitogefúrica & quitogefúrica & quitogefúrica e enáulica & enáulica & quitonica, enáulica, porfirica \\
\hline & Dist. ref. & $\begin{array}{l}\text { película ao redor do } \\
\text { esqueleto } \\
\end{array}$ & sem relação & $\begin{array}{l}\text { fina pelicula ao redor e } \\
\text { fazendo ponte no esqueleto }\end{array}$ & $\begin{array}{l}\text { pelíicula ao redor do } \\
\text { esqueleto }\end{array}$ & sem relação \\
\hline & $\begin{array}{l}\text { Estruturas } \\
\text { Plásmicas }\end{array}$ & isótico & isótico & isótico & isótico & isótico \\
\hline \multirow{5}{*}{ POROS } & Tipo & empilhamento simples & empilhamento simples & empilhamento complexo & empilhamento complexo & empilhamento simples \\
\hline & Forma & irregulares & irregulares & irregulares & irregulares & irregulares \\
\hline & Origem & pedoporos & pedoporos & pedoporos & pedoporos & pedoporos \\
\hline & Comunicação & fort. intercomunicante & fort. intercomunicante & fort. intercomunicante & fort. intercomunicante & fort. comunicante \\
\hline & Alisamento & ortoporos & ortoporos & ortoporos & ortoporos & ortoporos \\
\hline \multicolumn{2}{|c|}{$\begin{array}{l}\text { OBSERVAÇÕES GERAIS E } \\
\text { FEIÇÕES PEDOLÓGICAS }\end{array}$} & $\begin{array}{l}\text { plasma isótico e matéria } \\
\text { orgânica preenchendo os } \\
\text { poros }\end{array}$ & $\begin{array}{l}\text { pápulas (?) com orientação } \\
\text { forte continua, limites nitidos }\end{array}$ & $\begin{array}{l}\text { cutãs de iluviação associado } \\
\text { aos poros e ao esqueleto }\end{array}$ & $\begin{array}{l}\text { pedotúbulos }(0,3 \mathrm{a}, 0,5 \mathrm{~mm}) \\
\text { com bordas alisadas e } \\
\text { recoberta por plasma }\end{array}$ & $\begin{array}{l}\text { ausência de cutãs, nódulos } \\
0,2 \mathrm{~mm} \text { e limites pouco } \\
\text { nítidos }\end{array}$ \\
\hline
\end{tabular}




\begin{tabular}{|c|c|c|c|c|c|c|}
\hline \multicolumn{7}{|c|}{ TRINCHEIRA } \\
\hline \multicolumn{2}{|c|}{$\begin{array}{c}\text { VOLUMES } \\
\text { PROFUNDIDADES (cm) }\end{array}$} & $\begin{array}{c}\text { Areia-franca } \\
5-15\end{array}$ & $\begin{array}{c}\text { Areia-Franca } \\
20-30\end{array}$ & $\begin{array}{c}\text { Franco-argilo-arenosa } \\
70-80 \\
\end{array}$ & $\begin{array}{c}\text { Franco-argilo-arenosa } \\
115-125\end{array}$ & $\begin{array}{c}\text { Franco-argilo-arenosa } \\
175-185 \\
\end{array}$ \\
\hline \multirow{3}{*}{$\begin{array}{l}\text { FUNDO } \\
\text { MATRICIAL } \\
(\%)\end{array}$} & Esqueleto & 60 & 55 & 35 & 40 & 30 \\
\hline & Plasma & 15 & 10 & 45 & 35 & 30 \\
\hline & Poros & 25 & 35 & 20 & 25 & 40 \\
\hline \multirow{8}{*}{ ESQUELETO } & Mineralogia & quartzo & quartzo & quartzo & quartzo & quartzo \\
\hline & Origem & in situ & in situ & in situ & in situ & in situ \\
\hline & Dimensão & areia fina e muito fina & areia fina e muito fina & areia fina e muito fina & areia fina e muito fina & areia fina e muito fina \\
\hline & Frequência & comum & comum & comum & comum & comum \\
\hline & Grau/Seleção & moderadamente selec. & moderadamente selec. & moderadamente selec. & moderadamente selec. & moderadamente selec. \\
\hline & Dist. base & aleatória & aleatória & aleatória & aleatória & aleatória \\
\hline & Dist. ref. & sem & sem & sem & sem & sem \\
\hline & Orientação & não orientados & não orientados & não orientados & não rientados & não orientados \\
\hline \multirow{5}{*}{ PLASMA } & Cor & bruno-avermelhada & bruno-avermelhada & vermelho-alaranjada & vermelho-alaranjada & vermelho-alaranjada \\
\hline & Orientação & sem & sem & orientação somente nos cutãs & sem & sem \\
\hline & Dist. base & $\begin{array}{l}\text { película ao redor do } \\
\text { esqueleto }\end{array}$ & película ao redor do esqueleto & porfirica & aglomerática e quitônica & $\begin{array}{l}\text { aglomerática, porfirica e } \\
\text { quitônica }\end{array}$ \\
\hline & Dist. ref. & aleatória/agrupada & agrupada & sem & sem & sem \\
\hline & $\begin{array}{l}\text { Estruturas } \\
\text { Plásmicas }\end{array}$ & isótico & isótico & isótico & isótico & isótico \\
\hline \multirow{5}{*}{ POROS } & Tipo & empilhamento simples & emp. complexo, cavidades & cavitários, emp. complexo & cavitários, emp. complexo & emp. complexo, cavitários \\
\hline & Forma & irregulares & irregulares & regulares & irregulares & irregulares \\
\hline & Origem & pedoporos & pedoporos & pedoporos & pedoporos & pedoporos \\
\hline & Comunicação & fort. intercomunicantes & fort. intercomunicantes & frac. intercomunicantes & fort. intercomunicantes & fort. intercomunicantes \\
\hline & Alisamento & ortoporos & otoporos & ortoporos e metaporos & ortoporos e metaporos & ortoporos e metaporos \\
\hline \multicolumn{2}{|c|}{$\begin{array}{l}\text { OBSERVAÇÕES GERAIS E } \\
\text { FEIÇÕES PEDOLÓGICAS }\end{array}$} & $\begin{array}{l}\text { plasma concentrado com } \\
\text { aspecto de pequenos } \\
\text { nódulos }(0,2 \text { a } 0,3 \mathrm{~mm})\end{array}$ & $\begin{array}{l}\text { pequenos nódulos } \\
\text { ferruginosos com limites } \\
\text { nítidos }\end{array}$ & $\begin{array}{l}\text { cutãs de iluviação com } \\
\text { orientação forte contínua } \\
\text { (porossépicos) }\end{array}$ & $\begin{array}{l}\text { plasma isótico, zonas } \\
\text { (granossépicas, porossépicas) }\end{array}$ & $\begin{array}{l}\text { cutãs de iluviação, } \\
\text { pedotúbulos }(0,2 \mathrm{~mm}) \text { com } \\
\text { parede lisa }\end{array}$ \\
\hline
\end{tabular}


Continuaçăo do Quadro síntese

\begin{tabular}{|c|c|c|c|c|c|c|c|}
\hline \multirow{2}{*}{\multicolumn{2}{|c|}{\begin{tabular}{|c|} 
TRINCHEIRA \\
VOLUMES \\
PROFUNDIDADES $(\mathrm{cm})$ \\
\end{tabular}}} & \multicolumn{6}{|c|}{ TR III } \\
\hline & & $\begin{array}{c}\text { Areia-franca } \\
5-15 \\
\end{array}$ & $\begin{array}{c}\text { Areia-franca } \\
25-35 \text { (interbandas) }\end{array}$ & $\begin{array}{c}\text { Franco-arenosa } \\
60-70 \text { (transição/E) }\end{array}$ & $\begin{array}{c}\text { Franco-arenosa } \\
60-70 \text { (transição/Bt) } \\
\end{array}$ & $\begin{array}{c}\text { Franco-argilo-arenosa } \\
90-100\end{array}$ & $\begin{array}{c}\begin{array}{c}\text { Franco-argila-arenosa } \\
175-185\end{array} \\
\end{array}$ \\
\hline \multirow{3}{*}{$\begin{array}{l}\text { FUNDO } \\
\text { MATRICIAL } \\
(\%)\end{array}$} & Esqueleto & 40 & 50 & 55 & 45 & 25 & 30 \\
\hline & Plasma & 30 & 5 & 10 & 30 & 60 & 35 \\
\hline & Poros & 30 & 45 & 35 & 25 & 15 & 35 \\
\hline \multirow{8}{*}{ ESQUELETO } & Mineralogia & quartzo & quartzo & quartzo & quartzo & quartzo & quartzo \\
\hline & Origem & in situ & in situ & in situ & in situ & in situ & in situ \\
\hline & Dimensão & areia fina e muito fina & areia fina e muito fina & areia fina e muito fina & areia fina e muito fina & areia fina e muito fina & areia fina e muito fina \\
\hline & Frequência & comum & comum & comum & comum & comum & comum \\
\hline & Grau/seleção & moderadamente selec. & moderadamente selec. & moderadamente selec. & moderadamente selec. & moderadamente selec. & moderadamente selec. \\
\hline & Dist. base & aleatória, agrupada & aleatória & aleatória & aleatória & aleatória & aleatória \\
\hline & Dist. ref. & sem relação & sem relação & sem relação & sem relação & sem relação & sem relação \\
\hline & Orientação & não orientados & não orientados & não orientados & não orientados & não orientado & não orientado \\
\hline \multirow{5}{*}{ PLASMA } & Cor & bruno-escura & bruno-avermelhada & bruno-avermelhada & vermelho-alaranjada & vermelho-alaranjada & vermetho-alaranjada \\
\hline & Orientação & sem & sem & sem & em geral isótico & setores, forte contínua & sem \\
\hline & Dist. base & $\begin{array}{l}\text { quito-gefúrica, } \\
\text { porfirica }\end{array}$ & quitônica & quitônica & porfirica & porfírica & aglomerática e porfírica \\
\hline & Dist. ref. & $\begin{array}{l}\text { película ao redor do } \\
\text { esqueleto }\end{array}$ & $\begin{array}{l}\text { película ao redor do } \\
\text { esqueleto }\end{array}$ & $\begin{array}{l}\text { película ao redor do } \\
\text { esqueleto }\end{array}$ & $\begin{array}{l}\text { película ao redor do } \\
\text { esqueleto }\end{array}$ & $\begin{array}{l}\text { película ao redor do } \\
\text { esqueleto }\end{array}$ & $\begin{array}{l}\text { película ao redor do } \\
\text { esqueleto }\end{array}$ \\
\hline & $\begin{array}{l}\text { Estruturas } \\
\text { Plásmicas }\end{array}$ & isótico & isótico em geral & isótico & $\begin{array}{l}\text { isótico com setores } \\
\text { cintilantes } \\
\text { (silassépicas) }\end{array}$ & isótico em geral & isótico em geral \\
\hline \multirow{5}{*}{ POROS } & Tipo & $\begin{array}{l}\text { emp. simples e } \\
\text { complexo }\end{array}$ & empithamento simples & empilhamento simples & $\begin{array}{l}\text { empilhamento } \\
\text { complexo }\end{array}$ & $\begin{array}{l}\text { empilhamento } \\
\text { complexo }\end{array}$ & empilhamento complexo \\
\hline & Forma & irregulares e fissuras & irregulares & irregulares & irregulares e regulares & irregulares, cavidades & cavidades \\
\hline & Origem & pedoporos e dissecação & pedoporos & pedoporos & pedoporos & pedoporos e metaporos & pedoporos \\
\hline & Comunicação & fort intercomunicantes & fort. intercomunicantes & fort comunicantes & frac. comunicantes & frac. comunicantes & fort. comunicantes \\
\hline & Alisamento & ortoporos e metaporos & ortoporos & ortoporos & ortoporos & ortoporos & ortoporos \\
\hline \multicolumn{2}{|c|}{$\begin{array}{l}\text { OBSERVAÇÕES GERAIS E } \\
\text { FEIÇÕES PEDOLÓGICAS }\end{array}$} & $\begin{array}{l}\text { plasma isótico, devido } \\
\text { a opacidade do ferro e } \\
\text { da matéria orgânica }\end{array}$ & $\begin{array}{l}\text { manchas de areia } \\
\text { lavada }\end{array}$ & $\begin{array}{l}\text { pequenos domínios } \\
\text { com maior com } \\
\text { centração de argila, } \\
\text { assépicos (silassépicos) }\end{array}$ & $\begin{array}{l}\text { plasma isótico, } \\
\text { algumas zonas sépicas } \\
\text { (porossépicas, } \\
\text { granossépicas) }\end{array}$ & $\begin{array}{l}\text { cutãs com orientacão } \\
\text { forte contínua, zonas } \\
\text { sépicas (porossépicas e } \\
\text { granossépicas) }\end{array}$ & $\begin{array}{l}\text { pedotúbulos (1,5mm) } \\
\text { com limites nitido mar- } \\
\text { cado por película cutâni- } \\
\text { ca de plasma }\end{array}$ \\
\hline
\end{tabular}


Continuação do Quadro sintese

\begin{tabular}{|c|c|c|c|c|c|c|c|}
\hline \multirow{2}{*}{\multicolumn{2}{|c|}{$\begin{array}{c}\text { TRINCHEIRA } \\
\text { VOLUMES } \\
\text { PROFUNDIDADES }(\mathrm{cm}) \\
\end{array}$}} & \multicolumn{6}{|c|}{ TR IV } \\
\hline & & $\begin{array}{c}\text { Areia-franca } \\
5-15\end{array}$ & $\begin{array}{l}\text { Areia-franca } \\
15-25\end{array}$ & $\begin{array}{c}\text { Franco-argilo-arenoso } \\
35-45\end{array}$ & $\begin{array}{l}\text { Nódulos } \\
\text { Ferruginosos }\end{array}$ & $\begin{array}{l}\text { Franco-argilo-arenosa } \\
90-100\end{array}$ & $\begin{array}{c}\text { Arenito Caiuá alterado } \\
160-170\end{array}$ \\
\hline \multirow{3}{*}{$\begin{array}{l}\text { FUNDO } \\
\text { MATRICIAL } \\
(\%)\end{array}$} & Esqueleto & 55 & 50 & 40 & 20 & 40 & 60 \\
\hline & Plasma & 10 & $<5$ & 30 & 75 & 45 & 15 \\
\hline & Poros & 35 & 45 & 30 & 5 & 15 & 25 \\
\hline \multirow{8}{*}{ ESQUELETO } & Mineralogia & quartzo & quartzo & quartzo & quartzo e opacos & quartzo & quartzo \\
\hline & Origem & in situ & in situ & in situ & in situ & in situ & in situ \\
\hline & Dimensão & areia fina $\mathrm{e}$ muito fina & areia fina e muito fina & areia fina e muito fina & areia fina e muito fina & areia fina e muito fina & areia fina e muito fina \\
\hline & Frequência & comum & comum & comum & comum & comum & comum \\
\hline & Grau/Seleção & moderadamente selec. & moderadamente selec. & moderadamente selec. & moderadamente selec. & moderadamente selec. & moderadamente selec. \\
\hline & Dist. base & aleatória & aleatória & aleatória & aleatória & aleatória & aleatória e agrupada \\
\hline & Dist. ref. & sem & sem & sem & sem & sem & sem \\
\hline & Orientação & não orientado & não orientado & não orientado & não orientado & não orientado & não orientado \\
\hline \multirow{5}{*}{ PLASMA } & Cor & bruno-escura & bruno-avermelhada & vermelho-alaranjada & vermelho-escura & vermelho-alaranjada & vermelho-violácea \\
\hline & Orientação & sem & sem & moder a forte continua & sem & sem & sem \\
\hline & Dist. base & aglomerática & mônica, quitônica & porfirica e quitônica & porfirica & porfirica e enáulica & porfirica e quitônica \\
\hline & Dist. ref. & $\begin{array}{l}\text { película ao redor do } \\
\text { esqueleto }\end{array}$ & sem & $\begin{array}{l}\text { película ao redor do } \\
\text { esqueleto }\end{array}$ & $\begin{array}{l}\text { sem, alguns com peli- } \\
\text { cula ao redor do nódulo }\end{array}$ & $\begin{array}{l}\text { película em torno dos } \\
\text { poros }\end{array}$ & $\begin{array}{l}\text { película em torno dos } \\
\text { poros e do esqueleto }\end{array}$ \\
\hline & $\begin{array}{l}\text { Estruturas Plás- } \\
\text { micas }\end{array}$ & isótico & isótico & sépico & isótico & isótico em geral & isótico em geral \\
\hline \multirow{5}{*}{ POROS } & Tipo & $\begin{array}{l}\text { emp. simples e comple- } \\
\text { xo }\end{array}$ & empilhamento simples & empilhamento simples & cavitários e físsural & \begin{tabular}{|l} 
empilhamento comple- \\
xo
\end{tabular} & $\begin{array}{l}\text { emp. simples e comple- } \\
\text { xo }\end{array}$ \\
\hline & Forma & irregulares & irregulares & irregulares & irregulares & irregulares & irregulares \\
\hline & Origem & pedoporos & pedoporos & pedoporos & pedoporos & pedoporos & pedoporos \\
\hline & Comunicação & frac. comunicantes & fort. comunicantes & fort comunicantes & frac. comunicantes & frac. comunicantes & frac. comunicantes \\
\hline & Alisamento & ortoporos & ortoporos & ortoporos & ortoporos & ortoporos e metaporos & ortoporos \\
\hline \multicolumn{2}{|c|}{$\begin{array}{l}\text { OBSERVAÇÕES GERAIS E } \\
\text { FEIÇÕES PEDOLÓGICAS }\end{array}$} & $\begin{array}{l}\text { pequenos nódulos (4,0 } \\
\text { mm) ferruginosos com } \\
\text { plasma isótico }\end{array}$ & $\begin{array}{l}\text { nódulos (l a } 3 \mathrm{~mm} \text { ) } \\
\text { com e sem alteração, } \\
\text { estrutura poffíica e } \\
\text { contatos nítidos }\end{array}$ & $\begin{array}{l}\text { zonas sépicas (porossé- } \\
\text { picas e granossépicas, } \\
\text { cutâs com orientação } \\
\text { forte contínua assoc. } \\
\text { aos noros }\end{array}$ & $\begin{array}{l}\text { nódulos sendo destruí- } \\
\text { do com saída de ferro } \\
\text { das bordas (aureola } \\
\text { amarelada) }\end{array}$ & $\begin{array}{l}\text { pedotúbulos, microfis- } \\
\text { suras zonas sépicas (po- } \\
\text { rossépicas) }\end{array}$ & $\begin{array}{l}\text { fissuras preenchidas } \\
\text { com material fino, zo- } \\
\text { nas assépicas (silassé- } \\
\text { picas) }\end{array}$ \\
\hline
\end{tabular}




\begin{tabular}{|c|c|c|c|c|c|c|c|}
\hline \multicolumn{8}{|c|}{$\begin{array}{c}\text { TRINCHEIRA } \\
\text { VOI }\end{array}$} \\
\hline \multicolumn{2}{|c|}{$\begin{array}{c}\text { VOLUMES } \\
\text { PROFUNDIDADES }(\mathrm{cm})\end{array}$} & $\begin{array}{c}\text { Areia-franca } \\
0-10 \\
\end{array}$ & $\begin{array}{c}\text { Areia } \\
30-40 \\
\end{array}$ & $\begin{array}{l}\text { Nódulos Ferruginosos } \\
30-40 \\
\end{array}$ & $\begin{array}{c}\text { Franco-arenosa } \\
55-65 \\
\end{array}$ & $\begin{array}{l}\text { Arenito Caiuá alterado } \\
80-90 \\
\end{array}$ & $\begin{array}{c}\text { Arenito Caiuá alterado } \\
120-130\end{array}$ \\
\hline \multirow{3}{*}{$\begin{array}{l}\text { FUNDO } \\
\text { MATRICIAL } \\
(\%)\end{array}$} & Esqueleto & 55 & 45 & 35 & 45 & 65 & 50 \\
\hline & Plasma & 10 & 5 & 50 & 40 & 20 & $15 ?$ \\
\hline & Poros & 35 & 50 & 15 & 15 & 15 & 35 \\
\hline \multirow{8}{*}{ ESQUELETO } & Mineralogia & quartzo & quartzo & quartzo & quartzo & $\begin{array}{l}\text { quartzo, feldspato, mi- } \\
\text { ca }\end{array}$ & quatzo, feldspato, mica \\
\hline & Origem & in situ & in situ & in situ & in situ & in situ & in situ \\
\hline & Dimensão & areia fina e muito fina & areia fina e muito fina & areia fina e muito fina & areia fina e muita fina & areia fina & areia fina \\
\hline & Frequência & comum & comum & comum & comum & comum & comum \\
\hline & Grau/Seleção & moderadamente selec. & moderadamente selec. & moderadamente selec. & moderamente selec. & moderadamente selec. & pobremente selec. \\
\hline & Dist. base & aleatória & aleatónia & aleatória & aleatória & aleatória & aleatória \\
\hline & Dist. ref. & sem & sem & sem & sem & sem & sem \\
\hline & Orientação & não orientado & não orientado & não orientado & não orientado & fraca finos/grosseiros & fraca finos/grosseiros \\
\hline \multirow{5}{*}{ PLASMA } & Cor & bruna-escura & bruna-escura & vermelho-alaranjada & vermelho-alaranjada & marrom-violácea & vermelho, marrom, \\
\hline & Orientação & sem & sem & zonas fraca contínua & zonas fraca contínua & sem & sem \\
\hline & Dist. base & mônica & mônica & porfirica & porfirica e quitônica & quitônica e porfírica & quitônica e porfirica \\
\hline & Dist. ref. & sem & $\begin{array}{l}\text { película ao redor dos } \\
\text { poros }\end{array}$ & $\begin{array}{l}\text { película ao redor dos } \\
\text { nódulos e poros }\end{array}$ & $\begin{array}{l}\text { película ao redor do } \\
\text { esqueleto }\end{array}$ & $\begin{array}{l}\text { película em tomo dos } \\
\text { poros e esqueleto }\end{array}$ & $\begin{array}{l}\text { película ao redor dos } \\
\text { poros esqueleto }\end{array}$ \\
\hline & $\begin{array}{l}\text { Estruturas Plás- } \\
\text { micas }\end{array}$ & isótico & isótico & sépico & sépico & isótico & isótico \\
\hline \multirow{5}{*}{ POROS } & Tipo & empilhamento simples & empilhamento simples & emp. complexo & empilhamente simples & empilhamento simples & emp. simples, fissuras \\
\hline & Forma & irregulares & irregulales & irregulares & irregulares & finos e irregulares & finos e irregulares \\
\hline & Origem & pedoporos & pedoporos & pedoporos & pedoporos & $\begin{array}{l}\text { pedoporos, } \\
\text { litorreliquias }\end{array}$ & $\begin{array}{l}\text { pedoporos, } \\
\text { litorreliquias }\end{array}$ \\
\hline & Comunicação & fort. comunicante & frac. comunicantes & frac. comunicantes & frac. comunicantes & mod. comunicantes & mod. comunicantes \\
\hline & Alisamento & ortoporos & ortoporos e metaporos & orto e metaporos & orto e metaporos & orto e metaporos & orto e metaporos \\
\hline \multicolumn{2}{|c|}{$\begin{array}{l}\text { OBSERVAÇÕES GERAIS E } \\
\text { FEIÇÕES PEDOLÓGICAS }\end{array}$} & $\begin{array}{l}\text { nódulos }(0,4 \mathrm{~mm}) \text { com } \\
\text { esqueleto orientado (es- } \\
\text { tratos) com saída de } \\
\text { ferro da borda }\end{array}$ & $\begin{array}{l}\text { nódulos com plasma } \\
\text { isótico no centro e com } \\
\text { uma película de cor } \\
\text { amarela brilhante }\end{array}$ & $\begin{array}{l}\text { plasma com zonas sépi- } \\
\text { cas (porossépicas e } \\
\text { granossépicas) }\end{array}$ & $\begin{array}{l}\text { nódulos alterados já } \\
\text { destruídos }\end{array}$ & $\begin{array}{l}\text { fissuras preenchidas } \\
\text { com plasma orientado } \\
\text { com zonas (porossépi- } \\
\text { cas e granossépicas) }\end{array}$ & $\begin{array}{l}\text { fissuras com plásma } \\
\text { orientado com zonas } \\
\text { (porossépicas e granos- } \\
\text { sépicas) }\end{array}$ \\
\hline
\end{tabular}


Toposseqüência de Sumaré 
Quadro sintese das descriç̋es morfológicas dos perfis de solos das trincheiras da toposseqüencia de Sumaré - Paranavai

\begin{tabular}{|c|c|c|c|c|c|c|c|c|c|}
\hline TR & $\begin{array}{l}\text { PROF. } \\
\text { (cm) }\end{array}$ & COR & TEXTURA & ESTRUTURA & CONSISTENCIA & POROSIDADE & $\begin{array}{l}\text { RAIZES EIOU } \\
\text { ATIVIDADE BIOLÓGICA }\end{array}$ & TRANSIÇÃO & OBSERVAÇŐES \\
\hline \multirow{5}{*}{ TR $\mid$} & $0-20$ & 5YR $4 / 4$ & areia-franca & $\begin{array}{l}\text { maclça, } \\
\text { grảos soltos }\end{array}$ & $\begin{array}{l}\text { não plástica e năo } \\
\text { pegajosa }\end{array}$ & $\begin{array}{l}\text { empilhamento simples, } \\
\text { macroporos abundantes }\end{array}$ & $\begin{array}{l}\text { poucas raizes, pouca } \\
\text { atividade biológica }\end{array}$ & difusa & $\begin{array}{l}\text { friável, manchas centimétricas de areia lavada, } \\
\text { frag. de carvazo vegetal, areia grossa }>0,5 \mathrm{~mm}\end{array}$ \\
\hline & $20-80$ & 5YR $4 / 6$ & areia-franca & $\begin{array}{c}\text { tendência a } \\
\text { subangular fraca }\end{array}$ & \begin{tabular}{|l|} 
ligeiramente plástica a \\
ligeiramente pegajosa
\end{tabular} & $\begin{array}{l}\text { empilhamento simples, } \\
\text { macroporos abundantes }\end{array}$ & $\begin{array}{c}\text { rafzes finas diminui, pouca } \\
\text { atividade biológica }\end{array}$ & gradual & $\begin{array}{c}\text { friável, manchas centimétricas de areia lavada, } \\
\text { frag. carvão, areia grossa }\end{array}$ \\
\hline & $80-120$ & $2,5 Y R 3 / 6$ & $\begin{array}{l}\text { franco- } \\
\text { arenosa }\end{array}$ & $\begin{array}{l}\text { subangular } \\
\text { pequena fraca }\end{array}$ & $\begin{array}{l}\text { ligeiramente plástica a } \\
\text { ligeiramente pegajosa }\end{array}$ & $\begin{array}{l}\text { empilhamento simples, } \\
\text { macroporos abundantes }\end{array}$ & $\begin{array}{l}\text { poucas raizes finas, pouca } \\
\text { atividade biológica }\end{array}$ & gradual & $\begin{array}{c}\text { friável, pequenos bolsóes de areia lavada, frag. } \\
\text { de carvăo, areja grossa }\end{array}$ \\
\hline & $120-160$ & $2,5 Y R 3 / 6$ & $\begin{array}{l}\text { franco } \\
\text { arenosa } \\
\end{array}$ & $\begin{array}{c}\text { maciça se desfaz em } \\
\text { microagregados }\end{array}$ & \begin{tabular}{|l|} 
ligeiramente plástica a \\
ligeiramente pegajosa
\end{tabular} & $\begin{array}{l}\text { empithamento simples, } \\
\text { macroporos abundantes }\end{array}$ & $\begin{array}{l}\text { raizes finas diminui, pouca } \\
\text { atividade biológica }\end{array}$ & gradual & $\begin{array}{l}\text { muito friảvel, zonas centimétricas de areia } \\
\text { lavada, frag. de carvảo, areia grossa }\end{array}$ \\
\hline & $160-2004$ & $2,5 Y R 3 / 6$ & $\begin{array}{l}\text { franco- } \\
\text { arenosa }\end{array}$ & $\begin{array}{c}\text { maciça se desfaz em } \\
\text { microagregados }\end{array}$ & \begin{tabular}{|l|} 
ligeiramente plástica a \\
ligeiramente pegajosa
\end{tabular} & $\begin{array}{l}\text { empithamento simples, } \\
\text { macroporos abundantes }\end{array}$ & $\begin{array}{l}\text { poucas raízes, pouca } \\
\text { atividade biológica }\end{array}$ & - & $\begin{array}{l}\text { muito friável, zonas centimétricas de areia } \\
\text { lavada, frag. de carvão, areia grossa }\end{array}$ \\
\hline \multirow{4}{*}{$\mathrm{R}$ VII } & $0-15$ & 5YR 4/6 & areia & $\begin{array}{l}\text { maclça, } \\
\text { gắos soltos }\end{array}$ & $\begin{array}{l}\text { năo plástica e não } \\
\text { pegajosa }\end{array}$ & $\begin{array}{l}\text { empilhamento simples, } \\
\text { macroporos abundantes }\end{array}$ & $\begin{array}{l}\text { raizes finas abundantes, } \\
\text { pouca atividade biológica }\end{array}$ & difusa & $\begin{array}{c}\text { friável, pequenos bolsóes de areia lavada, frag } \\
\text { de carvảo, areia grossa pouca }\end{array}$ \\
\hline & $15-55$ & $5 Y R 4 / 6$ & areja-franca & $\begin{array}{c}\text { subangular } \\
\text { pequena fraca }\end{array}$ & $\begin{array}{l}\text { năo plástica e năo } \\
\text { pegajosa }\end{array}$ & $\begin{array}{l}\text { empilhamento simples, } \\
\text { macroporos abundantes }\end{array}$ & $\begin{array}{c}\text { poucas raizes finas, pouca } \\
\text { atividade biológica }\end{array}$ & difusa & $\begin{array}{c}\text { friável, pedotúbulos preenchidos por areia lavada } \\
\text { frag. carvão, areia grossa pouca }\end{array}$ \\
\hline & $55 \cdot 70$ & 2,5YR 3/6 & $\begin{array}{c}\text { franco-argilo- } \\
\text { arenosa }\end{array}$ & $\begin{array}{c}\text { subangular } \\
\text { pequena moderada }\end{array}$ & \begin{tabular}{|l|} 
ligeiramente plástica a \\
ligeiramente pegajosa \\
\end{tabular} & $\begin{array}{l}\text { empilhamento simples, } \\
\text { macroporos abundantes }\end{array}$ & $\begin{array}{c}\text { poucas raizes finas, pouca } \\
\text { atividade biológica }\end{array}$ & difusa & $\begin{array}{c}\text { faces estruturais e pequenos bolsoles com areia } \\
\text { lavada, arela grossa pouca }\end{array}$ \\
\hline & $70-160+$ & 2,5 YR $3 / 6$ & $\begin{array}{c}\text { franco-argito- } \\
\text { arenosa }\end{array}$ & $\begin{array}{l}\text { subangular } \\
\text { pequena média }\end{array}$ & $\begin{array}{l}\text { plástica e } \\
\text { pegajosa }\end{array}$ & $\begin{array}{l}\text { empilhamento simples, } \\
\text { macroporos abundantes }\end{array}$ & $\begin{array}{l}\text { raizes ausentes, pouca } \\
\text { atividade biológica }\end{array}$ & - & $\begin{array}{c}\text { friável, faces estruturais e canais de antigas } \\
\text { raizes preenchidos por areia lavada }\end{array}$ \\
\hline \multirow{4}{*}{$R \vee$} & $0-30$ & SYR 4/4 & areia-franca & $\begin{array}{l}\text { maciça, } \\
\text { grăos soltos }\end{array}$ & $\begin{array}{l}\text { nåo plástica e năo } \\
\text { pegajosa }\end{array}$ & $\begin{array}{l}\text { empilhamento simples, } \\
\text { macroporos abundantes }\end{array}$ & $\begin{array}{l}\text { poucas raizes finas, pouca } \\
\text { atividade bilogica }\end{array}$ & oifusa & $\begin{array}{l}\text { friável, poros tubulares preenchidos por areia } \\
\text { lavada, frag. de carvão, areia grossa diminui }\end{array}$ \\
\hline & $30-60$ & $2,5 Y R 3 / 6$ & $\begin{array}{l}\text { franco- } \\
\text { arenosa }\end{array}$ & $\begin{array}{l}\text { subangular se desfaz } \\
\text { em microagregados }\end{array}$ & $\begin{array}{l}\text { năo plástica e năo } \\
\text { pegajosa }\end{array}$ & empilhamento simples & $\begin{array}{c}\text { poucas raizes finas, pouca } \\
\text { atividade biologica }\end{array}$ & difusa & $\begin{array}{c}\text { frível, areia lavada preenchendo a porosidade } \\
\text { tubular, areia grossa pouca }\end{array}$ \\
\hline & $60-115$ & $2,5 \mathrm{yR} 3 /$ & $\begin{array}{c}\text { franco-argilo- } \\
\text { arenosa }\end{array}$ & $\begin{array}{l}\text { subangular } \\
\text { pequena média }\end{array}$ & $\begin{array}{l}\text { plástica e } \\
\text { pegajosa }\end{array}$ & empilhamento simples & $\begin{array}{l}\text { poucas raizes finas, pouca } \\
\text { atividade biológica }\end{array}$ & difusa & $\begin{array}{l}\text { poros tubulares preenchidos por material escurd } \\
\text { areia grossa pouca } \\
\end{array}$ \\
\hline & $115-160+$ & 2,5 YR $3 / 4$ & $\begin{array}{l}\text { franco- } \\
\text { arenosa }\end{array}$ & $\begin{array}{l}\text { subangular se desfaz } \\
\text { em microagregados }\end{array}$ & $\begin{array}{l}\text { ligeiramente plástica a } \\
\text { ligeiramente pegajosa }\end{array}$ & $\begin{array}{l}\text { empithamento simples, } \\
\text { macroporos abundantes }\end{array}$ & $\begin{array}{l}\text { poucas raizes finas, pouca } \\
\text { atividade biológica }\end{array}$ & - & $\begin{array}{c}\text { muito friável, presença de areia lavada } \\
\text { preenchendo pequenos poros e canais de antiga } \\
\text { ralzes }\end{array}$ \\
\hline
\end{tabular}


Continuação do Quadro sintese

\begin{tabular}{|c|c|c|c|c|c|c|c|c|c|}
\hline TR & $\begin{array}{l}\text { PROF. } \\
(\mathrm{cm})\end{array}$ & COR & TEXTURA & ESTRUTURA & CONSISTENCIA & POROSIDADE & $\begin{array}{l}\text { RAIZES E/OU } \\
\text { ATIVIDADE BIOLÓGICA }\end{array}$ & TRANSIÇAO & OBSERVAÇOESS \\
\hline \multirow{4}{*}{ R VIII } & 0.35 & 5YR 4/6 & areia-franca & $\begin{array}{c}\text { maciça }_{1} \\
\text { grảos soltos }\end{array}$ & $\begin{array}{l}\text { năo plástica e năo } \\
\text { pegajosa }\end{array}$ & empilhamento simples & $\begin{array}{c}\text { poucas raizes finas, pouca } \\
\text { atividade biologica }\end{array}$ & gradual & $\begin{array}{c}\text { friável, poros tubulares preenchidos por materia } \\
\text { escuro, bolsōes de areia lavada }\end{array}$ \\
\hline & $35-65$ & $2,5 Y R 3 / 6$ & $\begin{array}{l}\text { franco- } \\
\text { arenosa }\end{array}$ & $\begin{array}{l}\text { subangular fraca se } \\
\text { desfaz em granular }\end{array}$ & $\begin{array}{l}\text { ligeiramente plástica a } \\
\text { ligeiramente pegajosa }\end{array}$ & $\begin{array}{l}\text { empithamento simples, } \\
\text { macroporos abundantes }\end{array}$ & $\begin{array}{c}\text { poucas raizes finas, pouca } \\
\text { atividade biologica }\end{array}$ & difusa & $\begin{array}{l}\text { friável, poros e canais de antigas ralzes } \\
\text { preenchidos com areia lavada }\end{array}$ \\
\hline & $65-90$ & $2.5 Y R 3 / 4$ & $\begin{array}{c}\text { franco- } \\
\text { arenosa } \\
\end{array}$ & $\begin{array}{c}\text { subangular } \\
\text { pequena fraca }\end{array}$ & $\begin{array}{l}\text { ligeiramerite plástica a } \\
\text { ligeiramente pegajosa }\end{array}$ & $\begin{array}{l}\text { empilhamento simples, } \\
\text { macroporos abundantes }\end{array}$ & $\begin{array}{c}\text { poucas raizes finas, pouca } \\
\text { atividade biológica }\end{array}$ & gradual & $\begin{array}{l}\text { poucos poros e canais de antigas raizes } \\
\text { preenchidos com areia lavada }\end{array}$ \\
\hline & $90-160+$ & 2,5YR $3 / 6$ & $\begin{array}{c}\text { franco-argilo- } \\
\text { arenosa }\end{array}$ & $\begin{array}{c}\text { maciça se desfaz em } \\
\text { microagregados }\end{array}$ & $\begin{array}{l}\text { ligeiramente plástica a } \\
\text { ligeiramente pegajosa }\end{array}$ & empithamento simples & $\begin{array}{c}\text { poucas raizes finas, pouca } \\
\text { atividade biológica }\end{array}$ & - & $\begin{array}{l}\text { friável, maior quantidade de areia lavada } \\
\text { associadas a antigas raizes }\end{array}$ \\
\hline \multirow{6}{*}{ TR It } & $0-20$ & $5 Y R \quad 4 / 6$ & areia-franca & $\begin{array}{l}\text { maciça, } \\
\text { grảos soltos }\end{array}$ & $\begin{array}{c}\text { năo plástica e ñăo } \\
\text { pegajosa }\end{array}$ & empilhamento simples & $\begin{array}{c}\text { poucas raizes finas, pouca } \\
\text { atividade biologica }\end{array}$ & difusa & $\begin{array}{c}\text { friável, poucos poros e pedotúbulos preenchido } \\
\text { com areia lavada elou material escuro }\end{array}$ \\
\hline & $20-90$ & 5YR 4/4 & areia-franca & $\begin{array}{l}\text { subangular } \\
\text { pequena fraca }\end{array}$ & $\begin{array}{l}\text { ligeiramente plástica a } \\
\text { ligeiramente pegajosa }\end{array}$ & empilhamento simples & $\begin{array}{l}\text { poucas ralzes finas, pouca } \\
\text { atividade biologica }\end{array}$ & difusa & friável, lentes centimétricas de areia lavada \\
\hline & $20-90$ & $5 Y R 4 / 4$ & areia-franca & $\begin{array}{c}\text { subangular } \\
\text { pequena fraca }\end{array}$ & $\begin{array}{l}\text { ligeiramente plástica a } \\
\text { ligeiramente pegajosa }\end{array}$ & $\begin{array}{l}\text { empithamento simples, } \\
\text { macroporos abundantes }\end{array}$ & $\begin{array}{c}\text { poucas ralzes finas, pouca } \\
\text { atividade biologica }\end{array}$ & difusa & $\begin{array}{l}\text { friável, pequenos poros e bolsoes preenchidos } \\
\text { com areia lavada }\end{array}$ \\
\hline & $90-130$ & $2,5 Y R 3 / 6$ & $\begin{array}{c}\text { franco- } \\
\text { arenosa } \\
\end{array}$ & $\begin{array}{c}\text { subangular fraca se } \\
\text { desfaz em granular }\end{array}$ & $\begin{array}{l}\text { ligeiramente plástica a } \\
\text { ligeiramente pegajosa }\end{array}$ & $\begin{array}{l}\text { empithamento simples, } \\
\text { macroporos abundantes }\end{array}$ & $\begin{array}{l}\text { poucas ralzes finas, pouca } \\
\text { atividade biologica }\end{array}$ & difusa & $\begin{array}{c}\text { friável, pequenos poros e bolsones preenchidos } \\
\text { com areia lavada }\end{array}$ \\
\hline & $130-160$ & $2.5 Y R 3 / 6$ & $\begin{array}{l}\text { franco- } \\
\text { arenosa }\end{array}$ & $\begin{array}{l}\text { subangular fraca se } \\
\text { desfaz em granular }\end{array}$ & $\begin{array}{l}\text { ligeiramente plástica a } \\
\text { ligeiramente pegajosasa }\end{array}$ & $\begin{array}{l}\text { empithamento simples, } \\
\text { macroporos abundantes }\end{array}$ & $\begin{array}{c}\text { poucas raizes finas, pouca } \\
\text { atividade bilogica }\end{array}$ & difusa & friável, pequena presença de areia lavada \\
\hline & $160-200+$ & $2.5 Y R 3 / 6$ & $\begin{array}{l}\text { franco- } \\
\text { afenosa }\end{array}$ & $\begin{array}{c}\text { maciça se desfaz em } \\
\text { microagregados }\end{array}$ & $\begin{array}{l}\text { ligeiramente plástica a } \\
\text { ligeiramente pegajosa }\end{array}$ & $\begin{array}{l}\text { empilhamento simples, } \\
\text { macroporos abundantes }\end{array}$ & $\begin{array}{c}\text { poucas raizes finas, pouca } \\
\text { atividade biológica }\end{array}$ & - & $\begin{array}{c}\text { muito friável, faces estruturais e pequenas } \\
\text { porçסes com areia lavada }\end{array}$ \\
\hline \multirow{5}{*}{ TR M } & $0-10$ & 5YR 4/6 & areia & $\begin{array}{c}\text { maciça se desfaz em } \\
\text { grāos soltos }\end{array}$ & $\begin{array}{l}\text { năo plástica e nãa } \\
\text { pegajosa }\end{array}$ & empilhamento simples & $\begin{array}{c}\text { poucas ralzes finas, pouca } \\
\text { atividade biológica }\end{array}$ & difusa & pequenos bolsóes com areia lavada \\
\hline & $10-40$ & 5YR 4/4 & areia-franca & $\begin{array}{c}\text { maciça se desfaz em } \\
\text { gråos soltos }\end{array}$ & $\begin{array}{c}\text { năo plástica e năo } \\
\text { peģajosa }\end{array}$ & $\begin{array}{l}\text { empilhamento simples, } \\
\text { macroporos abundantes }\end{array}$ & $\begin{array}{c}\text { poucas raizes finas, pouca } \\
\text { atividade biologica }\end{array}$ & difusa & friável, pequena presença de areia lavada \\
\hline & $40-90$ & 2,5 YR $3 / 6$ & areia-franca & $\begin{array}{c}\text { subangular } \\
\text { pequena fraca } \\
\end{array}$ & $\begin{array}{l}\text { ligeiramente plástica a } \\
\text { ligeiramente pegajosa }\end{array}$ & $\begin{array}{l}\text { empilhamento simples, } \\
\text { macroporos abundantes }\end{array}$ & $\begin{array}{l}\text { raras raizes finas, pouca } \\
\text { atividade biologica }\end{array}$ & difusa & $\begin{array}{l}\text { frável, poucos pedotúbulos e tolsర̋es } \\
\text { preenchidos por areia lavada }\end{array}$ \\
\hline & $90-150$ & $2,5 Y R 3 / 6$ & areia-franca & $\begin{array}{c}\text { maciça se desfaz em } \\
\text { microagregados }\end{array}$ & $\begin{array}{l}\text { ligeiramente plástica a } \\
\text { ligeiramente pegajosa }\end{array}$ & $\begin{array}{l}\text { empilhamento simples, } \\
\text { macroporos abundantes }\end{array}$ & $\begin{array}{c}\text { poucas raizes finas, pouca } \\
\text { atividade biołógica }\end{array}$ & difusa & muito friável \\
\hline & $150-200+$ & $2,5 Y R 4 / 6$ & arela-franca & $\begin{array}{c}\text { maciça se desfaz em } \\
\text { microzarecados }\end{array}$ & $\begin{array}{l}\text { ligeiramente plástica a } \\
\text { ligeiramente_osaiosása }\end{array}$ & $\begin{array}{l}\text { empilhamento simples, } \\
\text { macroboros abundantes }\end{array}$ & $\begin{array}{c}\text { poucas raizes finas, pouca } \\
\text { atividade biolóoica }\end{array}$ & - & muit \\
\hline
\end{tabular}


Continuaçăo do Quadro sintese

\begin{tabular}{|c|c|c|c|c|c|c|c|c|c|}
\hline TR & $\begin{array}{l}\text { PROF. } \\
(\mathrm{cm})\end{array}$ & COR & TEXTURA & ESTRUTURA & CONSISTENCIA & POROSIDADE & $\begin{array}{l}\text { RALZES EIOU } \\
\text { ATIVIDADE BIOLÓGICA }\end{array}$ & TRANSIÇAOO & OBSERVAÇŐES \\
\hline \multirow{5}{*}{ TRIV } & 0.20 & 5YR 4/4 & areia & $\begin{array}{l}\text { maciça, } \\
\text { gräos soltos }\end{array}$ & $\begin{array}{l}\text { não plástica e năo } \\
\text { pegajosa }\end{array}$ & empilhamento simples & $\begin{array}{c}\text { raizes finas, pouca atividade } \\
\text { biológica }\end{array}$ & difusa & $\begin{array}{c}\text { friável, pequenos bolsరes de areia lavada, frag } \\
\text { de carvăo }\end{array}$ \\
\hline & $20-50$ & SYR 4/6 & areia-franca & $\begin{array}{l}\text { subangular } \\
\text { pequena fraca }\end{array}$ & $\begin{array}{l}\text { nảo plástica e năo } \\
\text { pegajosa }\end{array}$ & $\begin{array}{l}\text { empilhamento simples, } \\
\text { macroporos abundantes }\end{array}$ & $\begin{array}{c}\text { ralzes finas, pouca atividade } \\
\text { biológica }\end{array}$ & difusa & $\begin{array}{c}\text { friável, poros e canais de antigas raizes } \\
\text { preenchidos com areia lavada, frag. de canvăo }\end{array}$ \\
\hline & $50-95$ & $2,5 Y R 3 / 6$ & arela-franca & $\begin{array}{c}\text { subangular } \\
\text { pequena fraca }\end{array}$ & $\begin{array}{l}\text { ligeiramente plástica a } \\
\text { ligeiramente pegajosa }\end{array}$ & $\begin{array}{l}\text { empilhamento simples, } \\
\text { macroporos abundantes }\end{array}$ & $\begin{array}{l}\text { poucas raizes finas, pouca } \\
\text { atividade biológica }\end{array}$ & difusa & $\begin{array}{c}\text { friável, porçठes de areia lavada preenchendo } \\
\text { pequenos poros e canais de antigas raizes }\end{array}$ \\
\hline & $95-150$ & $2,5 Y R$ Y/6 & areia-franca & $\begin{array}{c}\text { maciça se desfaz em } \\
\text { microagregados }\end{array}$ & \begin{tabular}{|l|} 
ligeiramente plástica a \\
ligeiramente pegajosa
\end{tabular} & $\begin{array}{l}\text { empithamento simples, } \\
\text { macroporos abundantes }\end{array}$ & $\begin{array}{l}\text { poucas ralzes finas, pouca } \\
\text { atividade biológica }\end{array}$ & difusa & $\begin{array}{c}\text { muito friavel, areia lavada nos poros maiores } \\
\text { canais de antigas raizes, frag. de carvăo }\end{array}$ \\
\hline & $150-200+$ & $2,5 Y R 3 / 6$ & areia-franca & $\begin{array}{c}\text { maciça se desfaz em } \\
\text { microagregados }\end{array}$ & $\begin{array}{l}\text { ligeiramente plástica a } \\
\text { ligeiramente pegajosa }\end{array}$ & $\begin{array}{l}\text { empilhamento simples, } \\
\text { macroporos abundantes }\end{array}$ & $\begin{array}{l}\text { poucas ralzes finas, pouca } \\
\text { atividade biologica }\end{array}$ & - & $\begin{array}{l}\text { muito friável, aumenta a presença da areia } \\
\text { lavada junto aos poros e canais, frag. de carvă }\end{array}$ \\
\hline \multirow{4}{*}{ TR V } & 0.20 & 5YR $4 / 4$ & areia-franca & $\begin{array}{l}\text { maciça, } \\
\text { grảos soltos }\end{array}$ & $\begin{array}{l}\text { näo plástica a năo } \\
\text { pegajosa }\end{array}$ & empithamento simples & $\begin{array}{c}\text { raizes finas, pouca atividade } \\
\text { biológica }\end{array}$ & difusa & friável, bolsర̃es de areia lavada \\
\hline & $20-35$ & 5YR $3 / 4$ & areia-franca & $\begin{array}{c}\text { maciça, } \\
\text { grăos soltos }\end{array}$ & $\begin{array}{l}\text { năo plástica e năo } \\
\text { pegajosa }\end{array}$ & $\begin{array}{l}\text { empilhamento simples, } \\
\text { macroporos abundantes }\end{array}$ & $\begin{array}{c}\text { ralzes finas, pouca atividade } \\
\text { biológica }\end{array}$ & difusa & $\begin{array}{c}\text { friável, poucos poros e bolsőes preenchidos } \\
\text { por areia lavada }\end{array}$ \\
\hline & $35-80$ & $2,5 Y R 3 / 6$ & areia-franca & $\begin{array}{c}\text { maciça se desfaz em } \\
\text { microagregados }\end{array}$ & $\begin{array}{l}\text { ligeiramente plástica a } \\
\text { ligeiramente pegajosa }\end{array}$ & $\begin{array}{l}\text { empilhamento simples, } \\
\text { macroporos abundante }\end{array}$ & $\begin{array}{l}\text { ralzes finas, abundante } \\
\text { atividade biologica }\end{array}$ & difusa & $\begin{array}{l}\text { muito friavel, grande quantidade de cupins, } \\
\text { canais e poros preenchidos por areia lavada }\end{array}$ \\
\hline & $80-200+$ & $2,5 Y R 3 / 6$ & areia-franca & $\begin{array}{l}\text { maciça se desfaz em } \\
\text { microaorenados. }\end{array}$ & $\begin{array}{l}\text { ligeiramente plástica a } \\
\text { ligeirzmente_néraiosal }\end{array} \mid$ & $\begin{array}{l}\text { empilhamento simples, } \\
\text { macromos abundantes }\end{array}$ & $\begin{array}{l}\text { raizes finas, abundante } \\
\text { atividadebiolónica }\end{array}$ & $=$ & $\begin{array}{l}\text { muito friável, aumenta a } \\
\text { tavada iumto aco poros }\end{array}$ \\
\hline
\end{tabular}


Descriçōes micromorfológicas dos perfis das trincheiras da toposseqüéncia de Sumaré - Paranavai

\begin{tabular}{|c|c|c|c|c|c|}
\hline \multicolumn{2}{|c|}{ TRINCHEIRA } & \multicolumn{4}{|c|}{ TR I } \\
\hline \multicolumn{2}{|c|}{$\begin{array}{c}\text { VOLUMES } \\
\text { PROFUNDIDADES }(\mathrm{cm})\end{array}$} & $\begin{array}{c}\text { Areia-franca } \\
10-20\end{array}$ & $\begin{array}{c}\text { Areia-franca } \\
45-55\end{array}$ & $\begin{array}{c}\text { Franco-arenosa } \\
90-100 \\
\end{array}$ & $\begin{array}{l}\text { Franco-arenosa } \\
170-180 \\
\end{array}$ \\
\hline \multirow{3}{*}{$\begin{array}{l}\text { FUNDO } \\
\text { MATRICIAL } \\
(\%)\end{array}$} & Esqueleto & 50 & 48 & 45 & 40 \\
\hline & Plasma & 5 & 12 & 15 & 18 \\
\hline & Poros & 45 & 40 & 40 & 42 \\
\hline \multirow{8}{*}{ ESQUELETO } & Mineralogia & quartzo & quartzo & quartzo & quartzo \\
\hline & Origem & in situ & in situ & in situ & in situ \\
\hline & Dimensão & areia muito fina a grossa & areia muito fina a grossa & areia muito fina a grossa & areia muito fina a grossa \\
\hline & Frequência & comum & comum & comum & comum \\
\hline & Grau/Seleção & pobremente selec. & pobremente selec. & pobremente selec. & pobremente selec. \\
\hline & Dist. base & aleatória & aleatória & aleatória & aleatória \\
\hline & Dist. ref. & sem & sem & sem & sem \\
\hline & Orientação & não orientado & não orientado & não orientado & não orientado \\
\hline \multirow{5}{*}{ PLASMA } & Cor & brumo-escura & bruno-escura & bruno-avermelhada & bruno-avermelhada \\
\hline & Orientação & sem & sem, domínios assépicos & sem a fraca contínua & sem \\
\hline & Dist. base & quito-gefúrica & quito-gefúrica, enáulica & quito-gefúrica, enáulica & quito-gefúrica, enáulica \\
\hline & Dist. ref. & película ao redor do esqueleto & $\begin{array}{l}\text { película ao redor do } \\
\text { esqueleto }\end{array}$ & $\begin{array}{l}\text { película ao redor do } \\
\text { esqueleto }\end{array}$ & $\begin{array}{l}\text { película ao redor do } \\
\text { esqueleto }\end{array}$ \\
\hline & $\begin{array}{l}\text { Estruturas Plás- } \\
\text { micas }\end{array}$ & isótico no geral & isótico no geral & isótico no geral & isótico, domínios assépicos \\
\hline \multirow{5}{*}{ POROS } & Tipo & emp. simples, cavidades & emp. simples, cavidades & emp. simples, cavidades & emp. simples, cavidades \\
\hline & Forma & irregulares & irregulares & irregulares & irregulares \\
\hline & Origem & pedoporos & pedoporos & pedoporos & pedoporos \\
\hline & Comunicação & fort comunicantes & fort comunicantes & fort. comunicantes & fort. comunicantes \\
\hline & Alisamento & ortoporos & ortoporos & ortoporos & ortoporos \\
\hline \multicolumn{2}{|c|}{$\begin{array}{l}\text { OBSERVAÇÕES GERAIS E } \\
\text { FEIÇÕES PEDOLÓGICAS }\end{array}$} & $\begin{array}{l}\text { Concentrações de plasma isótico- } \\
\text { formando manchas, estrut de base } \\
\text { enáulica }\end{array}$ & $\begin{array}{l}\text { plasma assépico (argilassépico), pre- } \\
\text { sença de estrutura de base enáulica }\end{array}$ & $\begin{array}{l}\text { o esqueleto grosseiro apresenta fissu- } \\
\text { ras preenchidas por plasma ferrugi- } \\
\text { noso isótico }\end{array}$ & $\begin{array}{l}\text { esqueleto com fissuras não preen- } \\
\text { chidas originadas por dissolução } \\
\text { guímica }\end{array}$ \\
\hline
\end{tabular}


Continuação do Quadro síntese

\begin{tabular}{|c|c|c|c|c|c|}
\hline \multirow{2}{*}{\multicolumn{2}{|c|}{$\begin{array}{c}\text { TRINCHEIRA } \\
\text { VOLUMES } \\
\text { PROFUNDIDADES }(\mathrm{cm})\end{array}$}} & \multicolumn{4}{|c|}{ TR VII } \\
\hline & & $\begin{array}{l}\text { Areia } \\
5-15\end{array}$ & $\begin{array}{l}\text { Franco-arenosa } \\
25-35\end{array}$ & $\begin{array}{l}\text { Franco-argilo-arenoso } \\
60-70\end{array}$ & $\begin{array}{l}\text { Franco-argilo-arenosa } \\
90-100\end{array}$ \\
\hline \multirow{3}{*}{$\begin{array}{l}\text { FUNDO } \\
\text { MATRICIAL } \\
(\%)\end{array}$} & Esqueleto & 50 & 50 & 42 & 40 \\
\hline & Plasma & 5 & 10 & 18 & 20 \\
\hline & Poros & 45 & 40 & 40 & 40 \\
\hline \multirow{8}{*}{ ESQUELETO } & Mineralogia & quartzo & quartzo & quartzo & quartzo \\
\hline & Origem & in situ & in situ & in situ & in situ \\
\hline & Dimensão & areia muito fina a média & areia muito fina a média & areia muito fina a média & areia muito fina a média \\
\hline & Frequência & comum & comum & comum & comum \\
\hline & Grau/Seleção & moderadamente selec. & moderadamente selec. & moderadamente selec. & moderadamente selec. \\
\hline & Dist. base & aleatória & aleatória & aleatória & aleatória \\
\hline & Dist. ref. & sem & sem & sem & sem \\
\hline & Orientação & não orientado & não orientado & não orientado & não orientado \\
\hline \multirow{5}{*}{ PLASMA } & Cor & bruno-escura & bruno-escura a vermelha & bruno-avermelhada & bruno-avermelhada \\
\hline & Orientação & sem & sem & sem, setores forte continua & sem, raros setores forte contínua \\
\hline & Dist. base & quito-gefúrica & quito-gefúrica & quito-gefúrica, porfinica aberta & quito-gefúrica, enáulica \\
\hline & Dist. ref. & $\begin{array}{l}\text { pelicula ao redor do } \\
\text { esqueleto }\end{array}$ & $\begin{array}{l}\text { película ao redor do } \\
\text { esqueleto }\end{array}$ & $\begin{array}{l}\text { película ao redor do } \\
\text { esqueleto }\end{array}$ & $\begin{array}{l}\text { película ao redor do } \\
\text { esqueleto }\end{array}$ \\
\hline & $\begin{array}{l}\text { Estruturas Plás- } \\
\text { micas }\end{array}$ & $\begin{array}{l}\text { isótico no geral, domínios assépi- } \\
\cos \end{array}$ & $\begin{array}{l}\text { isótico no geral, dominios } \\
\text { sépicos }\end{array}$ & $\begin{array}{l}\text { isótico no geral, domínios } \\
\text { sépicos }\end{array}$ & isótico no geral, domínios sépicos \\
\hline \multirow{5}{*}{ POROS } & Tipo & emp. simples, cavidades & emp. simples & emp. simples, cavidades, canais & emp. simples, cavidades \\
\hline & Forma & irregulares & inegulares & irregulares & irregulares \\
\hline & Origem & pedoporos & pedoporos & pedoporos & pedoporos \\
\hline & Comunicação & fort. comunicantes & fort comunicantes & fort. comunicantes & fort. comunicantes \\
\hline & Alisamento & ortoporos & ortoporos & ortoporos & ortoporos \\
\hline \multicolumn{2}{|c|}{$\begin{array}{l}\text { OBSERVAÇÕES GERAIS E } \\
\text { FEICÕES PEDOLÓGICAS }\end{array}$} & $\begin{array}{l}\text { plasma isótico concentrado em fai- } \\
\text { xas (estrutura de base profirica } \\
\text { aberta) }\end{array}$ & $\begin{array}{l}\text { dominios de plasma sépico (granossé- } \\
\text { pico) }\end{array}$ & $\begin{array}{l}\text { raros framgentos de cutãs a estrutura } \\
\text { de base porfirica está sendo desman- } \\
\text { telada para originar a enánlia }\end{array}$ & $\begin{array}{l}\text { plasma sépico (granossépico), ra- } \\
\text { ros cutãs, estrutura de base enáuli- } \\
\text { ca }\end{array}$ \\
\hline
\end{tabular}




\begin{tabular}{|c|c|c|c|c|c|}
\hline \multirow{2}{*}{\multicolumn{2}{|c|}{$\begin{array}{c}\text { TRINCHEIRA } \\
\text { VOLUMES } \\
\text { PROFUNDMADES }(\mathrm{cm})\end{array}$}} & \multicolumn{4}{|c|}{ TR VI } \\
\hline & & $\begin{array}{c}\text { Areia-franca } \\
5-15 \\
\end{array}$ & $\begin{array}{c}\text { Franco-arenosa } \\
40-50 \\
\end{array}$ & $\begin{array}{c}\text { Franco-argilo-arenosa } \\
75-85 \\
\end{array}$ & $\begin{array}{c}\text { Franco-argilo-arenosa } \\
140-150 \\
\end{array}$ \\
\hline \multirow{3}{*}{$\begin{array}{c}\text { FUNDO } \\
\text { MATRICIAL } \\
(\%) \\
\end{array}$} & Esqueleto & 55 & 50 & 40 & 42 \\
\hline & Plasma & 8 & 15 & 20 & 18 \\
\hline & Poros & 37 & 35 & 40 & 40 \\
\hline \multirow{8}{*}{ ESQUELETO } & Mineralogia & quartzo & quartzo & quartzo & quartzo \\
\hline & Origem & in situ & in situ & in situ & in situ \\
\hline & Dimensão & areia muito fina a média & areia muito fina a média & areia muito fina a média & areia muito fina a média \\
\hline & Frequência & comum & comum & comum & comum \\
\hline & Grau/Seleção & moderadamente selec. & moderadamente selec. & moderadamente selec. & moderadamente selec. \\
\hline & Dist. base & aleatória & aleatória & aleatória e agrupada & aleatória \\
\hline & Dist. ref. & sem & sem & sem & sem \\
\hline & Orientação & não orientado & não orientado & não orientado & não orientado \\
\hline \multirow{5}{*}{ PLASMA } & Cor & bruno-escura & bruno-escura a avermelhada & bruno-avermelhada tons alaranjado & $\begin{array}{l}\text { brumo-avermelhada tons alaranja- } \\
\text { do }\end{array}$ \\
\hline & Orientação & sem & sem, domínios forte contínua & sem, domínios forte contínua & sem, domínios forte contínua \\
\hline & Dist. base & quito-gefúrica & quito-gefúrica & porfirica aberta e quito-gefúrica & quito-gefúrica e enáulica \\
\hline & Dist. ref. & película ao redor do esqueleto & película ao redor do esqueleto & película ao redor do esqueleto & película ao redor do esqueleto \\
\hline & $\begin{array}{l}\text { Estruturas Plás- } \\
\text { micas }\end{array}$ & isótico no geral & isótico, setores sépicos & isótico, setores sépicos & isótico, setores sépicos \\
\hline \multirow{5}{*}{ POROS } & Tipo & emp. simples & emp. simples, cavidades & emp. simples, cavidades & emp. simples cavidades, canais \\
\hline & Forma & irregular & irregular & irregular & irregular \\
\hline & Origem & pedoporos & pedoporos & pedoporos & pedoporos \\
\hline & Comunicação & fort. comunicamtes & fort comunicantes & fort comunicantes & fort. comunicantes \\
\hline & Alisamento & ortoporos & ortoporos & ortoporos & ortoporos \\
\hline \multicolumn{2}{|c|}{$\begin{array}{l}\text { OBSERVAÇÕES GERAIS E } \\
\text { FEIÇÕES PEDOLÓGICAS }\end{array}$} & $\begin{array}{l}\text { domínios com estrut. de base môni- } \\
\text { ca, o esqueleto grosseiro apresenta } \\
\text { fissuras preenchidas com plasma } \\
\text { isótico }\end{array}$ & $\begin{array}{l}\text { plasma sépico (granossépico e secun- } \\
\text { dariamente porossépico) }\end{array}$ & $\begin{array}{l}\text { plasma sépico (granossépico), restos } \\
\text { de cutãs parecem estarem deslocados } \\
\text { de sua posiçâo original }\end{array}$ & $\begin{array}{l}\text { plasma sépico (ranossépico e po- } \\
\text { rossépico), estrutura de base } \\
\text { enáulica predomina }\end{array}$ \\
\hline
\end{tabular}


Continuaçăo do Quadro sintese

\begin{tabular}{|c|c|c|c|c|c|}
\hline \multirow{2}{*}{\multicolumn{2}{|c|}{$\begin{array}{c}\text { TRINCHEIRA } \\
\text { VOLUMES } \\
\text { PROFUNDIDADES }(\mathrm{cm})\end{array}$}} & \multicolumn{4}{|c|}{ TR VIII } \\
\hline & & $\begin{array}{l}\text { Areia-franca } \\
10-20\end{array}$ & $\begin{array}{l}\text { Franco-arenosa } \\
40-50 \\
\end{array}$ & $\begin{array}{c}\text { Areia-franca } \\
65-75 \\
\end{array}$ & $\begin{array}{l}\text { Franco-argilo-arenosa } \\
70-80 \\
\end{array}$ \\
\hline \multirow{3}{*}{$\underset{\substack{\text { FUNDDO } \\
\text { MATRICIAL }}}{ }$} & Esqueleto & 50 & 45 & 40 & 40 \\
\hline & Plasma & 10 & 15 & 20 & 20 \\
\hline & Poros & 40 & 40 & 40 & 40 \\
\hline \multirow{8}{*}{ ESQUELETO } & Mineralogia & quartzo & quartzo & quartzo & quartzo \\
\hline & Origem & in situ & in situ & in situ & in situ \\
\hline & Dimensão & areia muito fina a média & areia muito fina a média & areia muito fina a média & areia muito fina a média \\
\hline & Frequência & comum & comum & comum & comum \\
\hline & Grau/Seleção & moderadamente selec. & moderadamente selec. & moderadamente selec. & moderadamente selec. \\
\hline & Dist. base & aleatória & aleatória & aleatória & aleatória \\
\hline & Dist. ref. & sem & sem & sem & sem \\
\hline & Orientação & não orientados & não orientados & não orientado & não orientados \\
\hline \multirow{5}{*}{ PLASMA } & Cor & bruno-escura a avermelhada & bruno-avermelhada & bruno-escura avermelhada & bruno-avermelhada \\
\hline & Orientação & sem, setores moderada contínua & sem, setores forte contínua & sem, setores forte contínua & sem, setores com forte contínua \\
\hline & Dist. base & quito-gefúrica & quito-gefúrica, porfirica aberta & quito-gefúrica, porfirica aberta & quito-gefúrica, prfirica aberta \\
\hline & Dist. ref. & sem & pelicula ao redor do esqueleto & película ao redor do esqueleto & película ao redor do esqueleto \\
\hline & $\begin{array}{l}\text { Estruturas Plás- } \\
\text { micas }\end{array}$ & isótico no geral, setores sépicos & isótico no geral, setores sépicos & isótico no geral, setores sépicos & isótico no geral, setores sépicos \\
\hline \multirow{5}{*}{ POROS } & Tipo & emp. simples & emp. simples, cavidades & emp. simples, cavidades & emp. simples, cavidades \\
\hline & Forma & irregulares & irregulares & irregulares & inegulares \\
\hline & Origem & pedoporos & pedoporos & pedoporos & pedoporos \\
\hline & Comunicação & fort. comunicantes & fort. comunicantes & fort. comunicantes & fort. comunicantes \\
\hline & Alisamento & ortoporos & ortoporos & ortoporos & ortoporos \\
\hline \multicolumn{2}{|c|}{$\begin{array}{l}\text { OBSERVAÇÕES GERAIS E } \\
\text { FEIÇÕES PEDOLÓGICAS }\end{array}$} & plasma sépico (granossépico) & $\begin{array}{l}\text { plasma sépico (granossépico), restos } \\
\text { de cutãs fissurados, com orientação } \\
\text { forte continua, deslocados de sua } \\
\text { posiçẫo original }\end{array}$ & $\begin{array}{l}\text { dominios com cutãs e cutãs fraturados } \\
\text { com orientação forte contínua a estru- } \\
\text { tura de base porfirica está sendo trans- } \\
\text { formada em enáulica }\end{array}$ & $\begin{array}{l}\text { plasma sépico (granossépico), } \\
\text { raros cutã̃s, a estrutura de base } \\
\text { porfirica aberta começa a ser } \\
\text { Iransformada em enáulica }\end{array}$ \\
\hline
\end{tabular}


Continuação do Quadro sintese

\begin{tabular}{|c|c|c|c|c|c|}
\hline \multicolumn{2}{|c|}{ TRINCHEIRA } & \multicolumn{4}{|c|}{ TR II } \\
\hline \multicolumn{2}{|c|}{$\begin{array}{c}\text { VOLUMES } \\
\text { PROFUNDIDADES }(\mathrm{cm})\end{array}$} & $\begin{array}{l}\text { Areia-franca } \\
5-15 \\
\end{array}$ & $\begin{array}{c}\text { Franco-arenosa } \\
65-75 \\
\end{array}$ & $\begin{array}{c}\text { Franco-arenosa } \\
105-115 \\
\end{array}$ & $\begin{array}{c}\text { Franco-arenosa } \\
170-180 \\
\end{array}$ \\
\hline \multirow{3}{*}{$\begin{array}{l}\text { FUNDO } \\
\text { MATRICIAL } \\
(\%)\end{array}$} & Esqueleto & 50 & 50 & 45 & 45 \\
\hline & Plasma & 10 & 15 & 15 & 20 \\
\hline & Poros & 40 & 35 & 40 & 35 \\
\hline \multirow{8}{*}{ ESQUELETO } & Mineralogia & quartzo & quartzo & quartzo & quartzo \\
\hline & Origem & in situ & in situ & in situ & in situ \\
\hline & Dimensão & areia muito fína a média & areia muito fina a média & areia muito fiana a areia média & areia muito fina a média \\
\hline & Frequência & comum & comum & comum & comum \\
\hline & Grau/Seleção & moderadamente selec. & moderadamente selec. & moderadamente selec. & moderadamente selec. \\
\hline & Dist. base & aleatória e agrupada & aleatória & aleatória e agrupada & aleatória \\
\hline & Dist. ref. & sem & sem & sem & sem \\
\hline & Orientação & não orientado & não orientado & não orientado & não orientado \\
\hline \multirow{5}{*}{ PLASMA } & Cor & bruno-escura a avermelhada & bruno-escura a vermelhada & bruno-escura a avermelhada & bruno-escura a avermelhada \\
\hline & Orientação & sem, setores forte continua & sem, setores assépicos & sem & sem, raros setores forte contínua \\
\hline & Dist. base & quitônica & quito-gefúrica, porfirica aberta & quito-gefúrica, porfirica aberta & quito-gefúrica, porfirica aberta \\
\hline & Dist. ref. & sem & película ao redor do esqueleto & película ao redor do esqueleto & película ao redor do esqueleto \\
\hline & $\begin{array}{l}\text { Estruturas Plás- } \\
\text { micas }\end{array}$ & $\begin{array}{l}\text { isótico no geral, raros dominios sépi- } \\
\text { cos }\end{array}$ & isótico no geral & isótico no geral, setores assépicos & isótico no geral, setores sépicos \\
\hline \multirow{5}{*}{ POROS } & Tipo & emp. simples & emp. simples, cavidades & emp. simples, cavidades & emp. simples, cavidades, canais \\
\hline & Forma & irregulares & irregulares & irregulares & irregulares \\
\hline & Origem & pedoporos & pedoporos & pedoporos & pedoporos \\
\hline & Comunicação & fort comunicantes & fort comunicantes & fort comunicantes & fot. comunicantes \\
\hline & Alisamento & ortoporos & ortoporos & ortoporos & ortoporos \\
\hline \multicolumn{2}{|c|}{$\begin{array}{l}\text { OBSERVAÇÕES GERAIS E } \\
\text { FEIÇÕES PEDOLÓGICAS }\end{array}$} & $\begin{array}{l}\text { plasma ferruginoso sépico (granossé- } \\
\text { pico) }\end{array}$ & $\begin{array}{l}\text { plasma assépico (argilassépico), o } \\
\text { esqueleto grosseiro está com fissu- } \\
\text { ras preenchidas com plasma ferrugi- } \\
\text { noso isótico }\end{array}$ & $\begin{array}{l}\text { plasma assépico (argilassépico), a es- } \\
\text { trutura de base porfírica aberta está } \\
\text { sendo transformada em enáulica }\end{array}$ & $\begin{array}{l}\text { plasma sépico (granossépico e } \\
\text { porossépico) relacionado a res- } \\
\text { tos de cutãs, pedotúbulo (isotú- } \\
\text { bulo) }\end{array}$ \\
\hline
\end{tabular}




\begin{tabular}{|c|c|c|c|c|c|}
\hline \multicolumn{6}{|c|}{ TRINCHEIRA } \\
\hline \multicolumn{2}{|c|}{$\begin{array}{c}\text { VOLUMES } \\
\text { PROFUNDIDADES }(\mathrm{cm})\end{array}$} & $\begin{array}{r}\text { Areia } \\
5-15 \\
\end{array}$ & $\begin{array}{c}\text { Areia-franca } \\
20-30 \\
\end{array}$ & $\begin{array}{c}\text { Areia-franca } \\
60-70 \\
\end{array}$ & $\begin{array}{c}\text { Areia-franca } \\
170-180 \\
\end{array}$ \\
\hline \multirow{3}{*}{$\begin{array}{c}\text { FUNDO } \\
\text { MATRICIAL } \\
(\%) \\
\end{array}$} & Esqueleto & 50 & 50 & 45 & 50 \\
\hline & Plasma & 5 & 8 & 15 & 15 \\
\hline & Poros & 45 & 42 & 40 & 40 \\
\hline \multirow{8}{*}{ ESQUELETO } & Mineralogia & quartzo & quartzo & quartzo & quartzo \\
\hline & Origem & in situ & in situ & in situ & in situ \\
\hline & Dimensão & areia muito fina a média & areia muito fina a média & areia muito fina a média & areia muito fina a média \\
\hline & Frequência & comum & comum & comum & comum \\
\hline & Grau/Seleção & moderadamente selec. & moderadamente selec. & moderadamente selec. & moderadamente selec. \\
\hline & Dist. base & aleatória & aleatória & aleatória & aleatória \\
\hline & Dist. ref. & sem & sem & sem & sem \\
\hline & Orientação & não orientado & não orientado & não orientado & não orientado \\
\hline \multirow{5}{*}{ PLASMA } & Cor & bruno-escura a preta & bruno-escura a preta & bruno-avermelhada & bruno-avermelhada \\
\hline & Orientação & sem & sem, setores moderada contínua & sem, setores moderada contínua & sem \\
\hline & Dist. base & quito-gefúrica e mônica & quito-gefúrica & quito-gefúrica, porfírica aberta & enáulica e quito-gefúrica \\
\hline & Dist. ref. & película ao redor do esqueleto & película ao redor do esqueleto & película ao redor do esqueleto & película ao redor do esqueleto \\
\hline & $\begin{array}{l}\text { Estruturas Plás- } \\
\text { micas }\end{array}$ & isótico & $\begin{array}{l}\text { isótico no geral, raros domínios } \\
\text { sépicos e assépicos }\end{array}$ & isótico no geral, raros domínios sépicos & isótico \\
\hline \multirow{5}{*}{ POROS } & Tipo & emp. simples, cavidades & emp. simples, cavidades, canais & emp. simples, cavidades & emp. simples, cavidades, canais \\
\hline & Forma & irregulares & irregulares & irregulares & irregulares \\
\hline & Origem & pedoporos & pedoporos & pedoporos & pedoporos \\
\hline & Comunicação & fort. comunicantes & fort comunicantes & fort. comunicantes & fort. comunicantes \\
\hline & Alisamento & ortoporos & ortoporos & ortoporos & otoporos \\
\hline \multicolumn{2}{|c|}{$\begin{array}{l}\text { OBSERV AÇÕES GERAIS E } \\
\text { FEICÕES PEDOLÓGICAS }\end{array}$} & $\begin{array}{l}\text { domínios com esqueleto lavado, es- } \\
\text { trutura de base mônica }\end{array}$ & $\begin{array}{l}\text { plasma sépico (granossépico e po- } \\
\text { rossépico) e assépico (argilassépico) }\end{array}$ & $\begin{array}{l}\text { ausência de cutãs, estrutura de base } \\
\text { enáulica predomina }\end{array}$ & plasma isótico microagregado \\
\hline
\end{tabular}


Continuação do Quadro síntese

\begin{tabular}{|c|c|c|c|c|c|}
\hline \multicolumn{2}{|c|}{ TRINCHEIRA } & \multicolumn{4}{|c|}{ TR IV } \\
\hline \multicolumn{2}{|c|}{$\begin{array}{c}\text { VOLUMES } \\
\text { PROFUNDIDADES }(\mathrm{cm})\end{array}$} & $\begin{array}{l}\text { Areia } \\
5-15 \\
\end{array}$ & $\begin{array}{c}\text { Areia-franca } \\
30-40\end{array}$ & $\begin{array}{l}\text { Franca-arenosa } \\
90-100\end{array}$ & $\begin{array}{l}\text { Franco-arenosa } \\
180-190 \\
\end{array}$ \\
\hline \multirow{3}{*}{$\begin{array}{l}\text { FUNDO } \\
\text { MATRICIAL } \\
(\%)\end{array}$} & Esqueleto & 50 & 47 & 45 & 40 \\
\hline & Plasma & 5 & 13 & 15 & 15 \\
\hline & Poros & 45 & 40 & 40 & 45 \\
\hline \multirow{8}{*}{ ESQUELETO } & Mineralogia & quartzo & quartzo & quartzo & quartzo \\
\hline & Origem & in situ & in situ & in situ & in situ \\
\hline & Dimensão & areia muito fina a areia média & areia muito fina a areia média & areia muito fína a média & areia muito fina a média \\
\hline & Frequência & comum & comum & comum & comum \\
\hline & Grau/Seleção & moderadamente selec. & moderadamente selec. & moderadamente selec. & moderadamente selec. \\
\hline & Dist. base & aleatória a agnupada & aleatória & aleatória a agrupada & aleatória \\
\hline & Dist. ref. & sem & sem & sem & sem \\
\hline & Orientação & não orientado & não orientado & não orientado & não orientado \\
\hline \multirow{5}{*}{ PLASMA } & Cor & bruno-escura a avermelhada & bruno-avermelhada & brun-avermelhada & bruno-avermelhada \\
\hline & Orientação & sem & sem, setores sépicos & sem, raros setores forte contínua & sem \\
\hline & Dist. base & quito-gefúrica & quito-gefúrica, porfírica aberta & quito-gerúrica, porfírica aberta & quito-gefürica \\
\hline & Dist. ref. & sem & película ao redor do esqueleto & película ao redor do esqueleto & película ao redor do esqueleto \\
\hline & $\begin{array}{l}\text { Estruturas Plás- } \\
\text { micas }\end{array}$ & isótico & isótico, setores forte contínua & isótico, raros domínios sépicos & isótico \\
\hline \multirow{5}{*}{ POROS } & Tipo & emp. simples & emp. simples, cavidades & emp. simples, cavidades & emp. simples, cavidades \\
\hline & Forma & inegulares & irregulares & irregulares & irregulares \\
\hline & Origem & pedoporos & pedoporos & pedoporos & pedoporos \\
\hline & Comunicação & fort. comunicantes & fort. comunicantes & fort. comunicamtes & fort. comunicantes \\
\hline & Alisamento & ortoporos & ortoporos & ortoporos & ortoporos \\
\hline \multicolumn{2}{|c|}{$\begin{array}{l}\text { OBSERVAÇÕS GERAIS E } \\
\text { FEICÕES PEDOLÓGICAS }\end{array}$} & $\begin{array}{l}\text { plasma isótico concentrado semelhan- } \\
\text { te a pequenos nódulos }(0,2 \mathrm{~mm} \text { ), pe- } \\
\text { dotúbulo (isotúbulo) }\end{array}$ & $\begin{array}{l}\text { plasma sépico (granossépico) rela- } \\
\text { cionado a restos de cutãs, presença } \\
\text { de pedotúbulo (isotúbulo) }\end{array}$ & $\begin{array}{l}\text { a estrutura de base porfirica aberta está } \\
\text { sendo transformada em enáulica (mi- } \\
\text { croagregados) }\end{array}$ & $\begin{array}{l}\text { estrutura de base essencialmen- } \\
\text { te enáulica }\end{array}$ \\
\hline
\end{tabular}




\begin{tabular}{|c|c|c|c|c|c|}
\hline \multicolumn{6}{|c|}{ TRINCHEIRA } \\
\hline \multicolumn{2}{|c|}{$\begin{array}{c}\text { VOLUMES } \\
\text { PROFUNDIDADES }(\mathrm{cm})\end{array}$} & $\begin{array}{c}\text { Areia-franca } \\
5-15 \\
\end{array}$ & $\begin{array}{c}\text { Areia-franca } \\
25-35 \\
\end{array}$ & $\begin{array}{c}\text { Areia-franca } \\
100-110\end{array}$ & $\begin{array}{c}\text { Franco-arenosa } \\
170-180 \\
\end{array}$ \\
\hline \multirow{3}{*}{$\begin{array}{l}\text { FUNDO } \\
\text { MATRICIAL } \\
(\%)\end{array}$} & Esqueleto & 53 & 50 & 45 & 45 \\
\hline & Plasma & 7 & 10 & 13 & 15 \\
\hline & Poros & 40 & 40 & 42 & 40 \\
\hline \multirow{8}{*}{ ESQUELETO } & Mineralogia & quartzo & quartzo & quartzo & quartzo \\
\hline & Origem & in situ & in situ & in situ & in situ \\
\hline & Dimensão & areia muito fina a média & areia muito fina a média & areia muito fina a média & areia muito fina a média \\
\hline & Frequência & comum & comum & comum & comum \\
\hline & Grau/Seleção & moderadamente selec. & moderadamente selec. & moderadamente selec. & moderadamente selec. \\
\hline & Dist. base & aleatória e agrupada & aleatória & aleatória & aleatória \\
\hline & Dist. ref. & sem & sem & sem & sem \\
\hline & Orientação & não orientado & não orientado & não orientado & não orientado \\
\hline \multirow{5}{*}{ PLASMA } & Cor & bruno-escura a avermelhada & bruno-avermelhada & bruno-avermelhada & bruno-avermelhada \\
\hline & Orientação & sem & sem, setores fraca contínua & sem, setores forte contínua & sem, setores forte contínua \\
\hline & Dist. base & quito-gefúrica & quito-gefúrica e enáulica & quito-gefúrica e enáulica & enáulica e quito-gefúrica \\
\hline & Dist. ref. & película ao redor do esqueleto & película ao redor do esqueleto & pelicula ao redor do esqueleto & película ao redor do esqueleto \\
\hline & $\begin{array}{l}\text { Estruturas Plás- } \\
\text { micas }\end{array}$ & isótico & isótico, domínios sépicos & isótico, domínios sépicos & $\begin{array}{l}\text { isótico no geral, pequenos do- } \\
\text { mínios assépicos }\end{array}$ \\
\hline \multirow{5}{*}{ POROS } & Tipo & emp. simples, cavidades & emp. simples, cavidades & emp. simples, cavidades & emp. simples, cavidades, canais \\
\hline & Forma & irregulares & irregulares & irregulares & irregulares \\
\hline & Origem & pedoporos & pedoporos & pedoporos & pedoporos \\
\hline & Comunicação & fort. comunicantes & fort. comunicantes & fort. comunicantes & fort. comunicantes \\
\hline & Alisamento & ortoporos & ortoporos & ortoporos & ortoporos \\
\hline \multicolumn{2}{|c|}{$\begin{array}{l}\text { OBSERVAÇÕES GERAIS E } \\
\text { FEIÇÕES PEDOLÓGICAS }\end{array}$} & $\begin{array}{l}\text { presença de pedotúbulos }(0,4 \mathrm{~mm}) \text { com } \\
\text { paredes alisadas (isotúbulo) }\end{array}$ & $\begin{array}{l}\text { plasma sépico (granossépico), raros } \\
\text { fragmentos de cutãs com orientação } \\
\text { forte contínua }\end{array}$ & $\begin{array}{l}\text { plasma sépico (granossépico e porossé- } \\
\text { pico), predomina a estrutura de base } \\
\text { enáulica }\end{array}$ & $\begin{array}{l}\text { onde o plasma está concentra- } \\
\text { do desenvolve estrutura de ba- } \\
\text { se assépica (argilassépica) }\end{array}$ \\
\hline
\end{tabular}


Toposseqüência de Umuarama 
Quadfo sintese das descriçōes morfológicas dos perfis das trincheiras da toposseqüência de Umuarama - Umuarama

\begin{tabular}{|c|c|c|c|c|c|c|c|c|c|}
\hline TR & $\begin{array}{l}\text { PROF. } \\
(\mathrm{cm})\end{array}$ & COR & TEXTURA & ESTRUTURA & CONSISTÊNCIA & POROSIDADE & $\begin{array}{l}\text { RAIZES EIOU } \\
\text { ATIVIDADE BIOLÓGICA }\end{array}$ & TRANSIÇAOO & OBSERVAÇOESS \\
\hline \multirow{4}{*}{ TR 1} & $0-20$ & $\begin{array}{l}5 Y R 4 / 4 \text { a } \\
2,5 Y R 4 / 4\end{array}$ & $\begin{array}{l}\text { franco- } \\
\text { arenosa }\end{array}$ & $\begin{array}{l}\text { subangular } \\
\text { pequena fraca }\end{array}$ & $\begin{array}{c}\text { nảo plástica e nåo } \\
\text { pegajosa }\end{array}$ & empithamento simples & $\begin{array}{c}\text { poucas raizes finas, pouca } \\
\text { atividade biológica }\end{array}$ & $\begin{array}{l}\text { plana } \\
\text { difusa }\end{array}$ & $\begin{array}{c}\text { friável, pequenos bolsōes de areia lavada, frag } \\
\text { de carvåo vegetal e nichos de insetos }\end{array}$ \\
\hline & $20-50$ & $\begin{array}{l}2,5 Y R 3 / 4 \\
\text { a } 3 / 6\end{array}$ & $\begin{array}{l}\text { Eranco- } \\
\text { arenosa }\end{array}$ & $\begin{array}{c}\text { blocos subangulares } \\
\text { pequena fraca }\end{array}$ & $\begin{array}{l}\text { ligeiramente plástica a } \\
\text { tigeiramente pegajosa }\end{array}$ & $\begin{array}{l}\text { empilhamento simples, } \\
\text { macroporos abundantes }\end{array}$ & $\begin{array}{c}\text { poucas raizes, abundante } \\
\text { atividade biológica }\end{array}$ & $\begin{array}{l}\text { plana } \\
\text { difusa }\end{array}$ & $\begin{array}{l}\text { muito friável, canais tubulares, poros } \\
\text { preenchidos por areia lavada, frag. de carvăo }\end{array}$ \\
\hline & $50-115$ & $\begin{array}{c}2,5 Y R 3 / 4 \\
\text { a } 3 / 6 \\
\end{array}$ & $\begin{array}{c}\text { franco- } \\
\text { arenosa } \\
\end{array}$ & $\begin{array}{c}\text { maciça se desfaz em } \\
\text { microagregados }\end{array}$ & $\begin{array}{l}\text { ligeiramente plástica a } \\
\text { ligeiramente pegajosa }\end{array}$ & $\begin{array}{l}\text { empithamento simples, } \\
\text { macroporos abundantes }\end{array}$ & $\begin{array}{l}\text { raizes diminui, abundante } \\
\text { atividade biológica }\end{array}$ & $\begin{array}{c}\text { plana } \\
\text { ondulada }\end{array}$ & $\begin{array}{l}\text { muito friável, bolsóes centimétricos de areia } \\
\text { lavada, nichos de insetos, frag. de carvăo }\end{array}$ \\
\hline & $115-200+$ & $2,5 Y R 3 / 4$ & $\begin{array}{l}\text { franco- } \\
\text { arenosa }\end{array}$ & $\begin{array}{c}\text { subangular } \\
\text { pequena moderada } \\
\end{array}$ & $\begin{array}{l}\text { plástica e } \\
\text { pegajosa }\end{array}$ & $\begin{array}{l}\text { empilhamento simples, } \\
\text { macroporos abundantes }\end{array}$ & $\begin{array}{l}\text { poucas rałzes, abundante } \\
\text { atividade biológica }\end{array}$ & - & $\begin{array}{c}\text { friável, porosidade tubular abundante, grande } \\
\text { quantidade de frag. de carvăo }\end{array}$ \\
\hline \multirow{4}{*}{ TR $\|$} & $0-26$ & $\begin{array}{c}\text { 5YR } 3 / 4 \text { a } \\
4 / 6\end{array}$ & areia-franca & $\begin{array}{l}\text { maciça, } \\
\text { gråos soltos }\end{array}$ & $\begin{array}{c}\text { năo plástica e nåo } \\
\text { pegajosa }\end{array}$ & empithamento simples & $\begin{array}{l}\text { poucas raizes finas, pouca } \\
\text { atividade biologica }\end{array}$ & gradual & $\begin{array}{c}\text { friável, bołsóes centimétricos de areia lavada, } \\
\text { frag. de carvăo }\end{array}$ \\
\hline & $26-75$ & $\begin{array}{c}2,53 / 4 \mathrm{a} \\
4 / 6\end{array}$ & areia-franca & $\begin{array}{l}\text { subangular } \\
\text { pequena fraca }\end{array}$ & $\begin{array}{l}\text { ligeiramente plástica a } \\
\text { ligeiramente pegajosa }\end{array}$ & $\begin{array}{l}\text { empilhamento simples, } \\
\text { macroporos abundantes }\end{array}$ & $\begin{array}{l}\text { poucas raizes, pouca } \\
\text { atividade biológica }\end{array}$ & gradual & $\begin{array}{c}\text { muito friável, canais tubulares, bolsరes } \\
\text { centimétricos de areia lavada, raros frag. } \\
\text { carvão }\end{array}$ \\
\hline & $75-150$ & $\begin{array}{c}2.5 Y R 3 / 4 \\
\text { a } 3 / 6 \\
\end{array}$ & $\begin{array}{l}\text { franco- } \\
\text { arenosa }\end{array}$ & $\begin{array}{c}\text { blocos subanguiares } \\
\text { mais resistentes }\end{array}$ & $\begin{array}{l}\text { ligeiramente plástica a } \\
\text { ligeiramente pegajosa }\end{array}$ & $\begin{array}{l}\text { empilhamento simples, } \\
\text { macroporos abundantes }\end{array}$ & $\begin{array}{l}\text { poucas raizes, abundante } \\
\text { atividade biologica }\end{array}$ & gradual & grande quantidade de canais tubulares \\
\hline & $150-200+$ & $2.5 Y R 3 / 4$ & $\begin{array}{l}\text { franco- } \\
\text { arenosa }\end{array}$ & $\begin{array}{c}\text { maciça se desfaz em } \\
\text { microagregados }\end{array}$ & $\begin{array}{l}\text { ligieramente płástica a } \\
\text { ligeiramente pegajosa }\end{array}$ & $\begin{array}{l}\text { empithamento simples, } \\
\text { macroporos abundantes }\end{array}$ & $\begin{array}{l}\text { poucas ralzes, abundante } \\
\text { atividade biológica }\end{array}$ & - & $\begin{array}{l}\text { muito friavel, grande quantidade de canais } \\
\text { tubulares, nichos de insetos }\end{array}$ \\
\hline \multirow{4}{*}{ TRI } & $0-30$ & $\begin{array}{l}5 Y R 3 / 4 \text { a } \\
2,5 Y R 3 / 4 \\
\end{array}$ & areia & $\begin{array}{c}\text { maciça se desfaz em } \\
\text { grãos soltos }\end{array}$ & $\begin{array}{l}\text { não plástica e não } \\
\text { pegajosa }\end{array}$ & empithamento simples & $\begin{array}{l}\text { ralzes abundantes, pouca } \\
\text { atividade biológica }\end{array}$ & clara & muito fríável \\
\hline & $30-130$ & $2,5 Y R 3 / 6$ & areia-franca & $\begin{array}{c}\text { maciça se desfaz em } \\
\text { microagreados }\end{array}$ & $\begin{array}{l}\text { ligeiramente plástica a } \\
\text { ligeiramente pegajosa }\end{array}$ & $\begin{array}{l}\text { empithamento simples, } \\
\text { macroporos abundantes }\end{array}$ & $\begin{array}{l}\text { poucas raizes, abundante } \\
\text { atividade biológica }\end{array}$ & $\begin{array}{l}\text { difusa } \\
\text { plana }\end{array}$ & multo friável, \\
\hline & $130-160$ & $2.5 Y R 3 / 6$ & areia-franca & $\begin{array}{c}\text { maciça se desfaz em } \\
\text { microagregados }\end{array}$ & \begin{tabular}{|l|} 
Iigeiramente plástica a \\
ligeiramente pegajosa
\end{tabular} & $\begin{array}{l}\text { empilhamento simples, } \\
\text { macroporos abundarites }\end{array}$ & $\begin{array}{l}\text { poucas raizes, abundante } \\
\text { atividade biologica }\end{array}$ & $\begin{array}{l}\text { difusa } \\
\text { plana }\end{array}$ & $\begin{array}{c}\text { muito friável, grande quantidade de canais } \\
\text { tubulares }\end{array}$ \\
\hline & $160-200+$ & $2,5 Y R 3 / 6$ & $\begin{array}{l}\text { franco- } \\
\text { atenosa }\end{array}$ & $\begin{array}{c}\text { maciça se desfaz em } \\
\text { michoadreados }\end{array}$ & $\begin{array}{l}\text { ligeiramente plástica a } \\
\text { liogeiramente_ogaloiosa }\end{array}$ & $\begin{array}{l}\text { empilhamento simples, } \\
\text { macroboros abundantes }\end{array}$ & $\begin{array}{l}\text { poucas raizes, abundante } \\
\text { atividade biolobica }\end{array}$ & - & $\begin{array}{c}\text { mutto friável, grande quantidade de canais } \\
\text { fubulares }\end{array}$ \\
\hline
\end{tabular}


Continuação do Quadro Sintese

\begin{tabular}{|c|c|c|c|c|c|c|c|c|c|}
\hline TR & $\begin{array}{l}\text { PROF. } \\
(\mathrm{cm})\end{array}$ & COR & TEXTURA & ESTRUTURA & CONSISTENCIA & POROSIDADE & $\begin{array}{l}\text { RAIZES EIOU } \\
\text { ATIVIDADE BIOLÓGICA }\end{array}$ & TRANSIÇAO & OBSERVAÇŌES \\
\hline \multirow{7}{*}{$R \|$} & $0-15$ & $2,5 Y R 3 / 4$ & areia-franca & $\begin{array}{c}\text { maciça, } \\
\text { grăos soltos }\end{array}$ & $\begin{array}{c}\text { năo plástica e nåo } \\
\text { pegajosa }\end{array}$ & empilhamento simples & $\begin{array}{l}\text { poucas raizes, pouca } \\
\text { atividade biológica }\end{array}$ & abrupta & $\begin{array}{c}\text { colúvio, fríavel, nódulos milimétricos de argila, } \\
\text { frag. de carvấo }\end{array}$ \\
\hline & $15-50$ & $\begin{array}{l}5 Y R 3 / 3 a \\
2,5 Y R 3 / 6\end{array}$ & areia & $\begin{array}{l}\text { maciça, } \\
\text { grảos soltos }\end{array}$ & $\begin{array}{l}\text { não plástica e năo } \\
\text { pegajosa }\end{array}$ & empilhamento simples & $\begin{array}{c}\text { poudas ralzes, pouca } \\
\text { atividade biológica }\end{array}$ & abrupta & $\begin{array}{c}\text { colüvio, friável, camadas milimétricas de } \\
\text { material fino, frag. carsåa }\end{array}$ \\
\hline & $50-74$ & $\begin{array}{c}5 \mathrm{YR} 3 / 4 \text { a } \\
4 / 6 \\
\end{array}$ & areia & $\begin{array}{c}\text { maciça, } \\
\text { grăos soltos }\end{array}$ & $\begin{array}{c}\text { năo plástica e năo } \\
\text { pegajosa }\end{array}$ & empilhamento simples & $\begin{array}{l}\text { poucas raizes, pouca } \\
\text { atividade biológica }\end{array}$ & abrupta & $\begin{array}{l}\text { colúvio, friável, camadas centimétricas de } \\
\text { materia orgánica e argila, frag. de carvăo }\end{array}$ \\
\hline & $74-85$ & $2.5 Y R 3 / 4$ & $\begin{array}{c}\text { franco- } \\
\text { arenosa }\end{array}$ & $\begin{array}{l}\text { subangular } \\
\text { pequena fraca }\end{array}$ & $\begin{array}{l}\text { ligeiramente plástica a } \\
\text { ligeiramente pegajosa }\end{array}$ & $\begin{array}{l}\text { empilhamento simples, } \\
\text { macroporos abundantes }\end{array}$ & $\begin{array}{l}\text { poucas rajzes, pouta } \\
\text { atividade biológica }\end{array}$ & abrupta & $\begin{array}{c}\text { coltuvio, friável, canais e faces estruturais com } \\
\text { areia lavada, frag. de carvão }\end{array}$ \\
\hline & $85-95$ & $\begin{array}{c}5 Y R 3 / 3 a \\
3 / 4\end{array}$ & areia-franca & $\begin{array}{l}\text { subangular } \\
\text { pequena moderada }\end{array}$ & $\begin{array}{l}\text { não piástica a năo } \\
\text { pegajosa }\end{array}$ & empilhamento simples & $\begin{array}{l}\text { poucas raizes, pouca } \\
\text { atividade biológica }\end{array}$ & difusa & $\begin{array}{c}\text { friável, comum a alternáncia de lentes } \\
\text { centimétricas de areia lavada clara, frag. de } \\
\text { carvão }\end{array}$ \\
\hline & $95-130$ & $\begin{array}{c}5 Y R 4 / 4 \text { a } \\
4 / 6\end{array}$ & areia-franca & $\begin{array}{l}\text { subangular } \\
\text { pequena fraca }\end{array}$ & $\begin{array}{l}\text { ligeiramente plástica a } \\
\text { ligeiramente pegajosa }\end{array}$ & $\begin{array}{l}\text { empilhamento simples, } \\
\text { macroporos poucos }\end{array}$ & $\begin{array}{l}\text { poucas ralzes, pouca } \\
\text { atividade biológica }\end{array}$ & difusa & $\begin{array}{c}\text { muito friável, poucos canais tubulares, frag. de } \\
\text { carvăo }\end{array}$ \\
\hline & $130.200+$ & $\begin{array}{l}2,5 Y R 3 / 4 \\
\text { a } 3 / 6\end{array}$ & $\begin{array}{l}\text { franco- } \\
\text { arenosa }\end{array}$ & $\begin{array}{l}\text { maciça se desfaz em } \\
\text { microagregados }\end{array}$ & $\begin{array}{l}\text { ligeiramente plastica a } \\
\text { ligeiramente pegajosa }\end{array}$ & $\begin{array}{l}\text { empilhamento simples, } \\
\text { macroporos abundantes }\end{array}$ & $\begin{array}{l}\text { poucas raizes, pouca } \\
\text { atividade bjológica }\end{array}$ & - & $\begin{array}{l}\text { muito friável, faces estruturais com areia } \\
\text { lavada, frag. de carvảo e ralzes grossas } \\
\text { (5cm diametro) }\end{array}$ \\
\hline
\end{tabular}


Descrições micromorfológicas dos perfis das trincheiras da toposseqüência de Umuarama - Umuarama

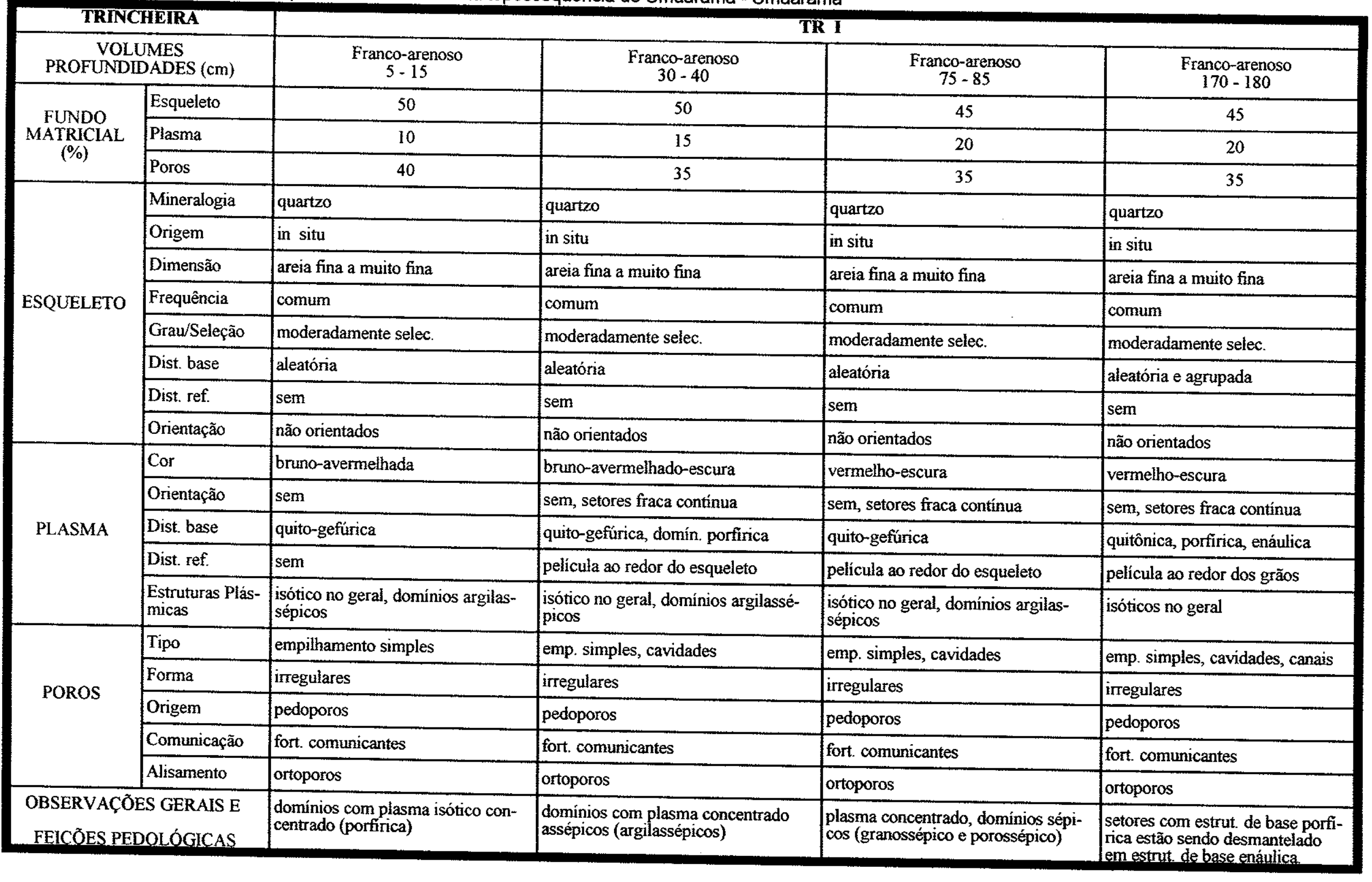


Continuação do Quadro sintese

\begin{tabular}{|c|c|c|c|c|c|}
\hline \multirow{2}{*}{\multicolumn{2}{|c|}{$\begin{array}{c}\text { TRINCHEIRA } \\
\text { VOLUMES } \\
\text { PROFUNDMADES }(\mathrm{cm})\end{array}$}} & \multicolumn{4}{|c|}{ TR II } \\
\hline & & $\begin{array}{l}\text { Areia- franca } \\
10-20\end{array}$ & $\begin{array}{l}\text { Areia-franca } \\
30-40 \\
\end{array}$ & $\begin{array}{l}\text { Franco-arenoso } \\
65-75 \\
\end{array}$ & $\begin{array}{l}\text { Franco-arenoso } \\
150-160 \\
\end{array}$ \\
\hline \multirow{3}{*}{$\begin{array}{l}\text { FUNDO } \\
\text { MATRRCIAL } \\
(\%)\end{array}$} & Esqueleto & 55 & 50 & 40 & 50 \\
\hline & Plasma & 5 & 10 & 20 & 20 \\
\hline & Poros & 45 & 40 & 40 & 30 \\
\hline \multirow{8}{*}{ ESQUELETO } & Mineralogia & quartzo & quartzo & quartzo & quartzo \\
\hline & Origem & in situ & in situ & in situ & in situ \\
\hline & Dimensão & areia fina a muito fina & areia fina a muito fina & areia fina a a muito fina & areia fina a muito fina \\
\hline & Frequência & comum & comum & comum & comum \\
\hline & Grau/Seleção & moderadamente selec. & moderadamente selec. & moderadamente selec. & moderadamente selec. \\
\hline & Dist. base & aleatória e agrupada & aleatória e agrupada & aleatória e agrupada & aleatória \\
\hline & Dist. ref. & sem & sem & sem & sem \\
\hline & Orientação & não orientados & sem, a fracamente orientados & sem & sem \\
\hline \multirow{5}{*}{ PLASMA } & Cor & brumo-escura & vermelho-escura-tons alaranjado & bruno-avermelhada-tons alaranjado & vermelho-escura-tons alaranjado \\
\hline & Orientação & sem & $\begin{array}{l}\text { sem, raros setores moderada contí- } \\
\text { nua }\end{array}$ & fraca, moderada continua & sem, domínios forte continua \\
\hline & Dist. base & quitônica & quito-gefúrica & quito-gefúrica e porfinica aberta & quito-gefúrica e enáulica \\
\hline & Dist. ref. & película ao redor do esqueleto & película ao redor do esqueleto & película ao redor do esqueleto & película ao redor do esqueleto \\
\hline & $\begin{array}{l}\text { Estruturas Plás- } \\
\text { micas }\end{array}$ & isótico no geral & isótico no geral & $\begin{array}{l}\text { isótico no geral, setores sépicos - } \\
\text { granossépicos e porossépicos }\end{array}$ & $\begin{array}{l}\text { isótico no geral, dominos } \\
\text { sépicos- granossépicos }\end{array}$ \\
\hline \multirow{5}{*}{ POROS } & Tipo & emp. simples, cavidades & emp. simples, cavidades & emp. simples, cavidades, canais & emp. simples, cavidades, canais \\
\hline & Forma & irregulares & irregulares & irregulares & irregulares \\
\hline & Origem & pedoporos & pedoporos & pedoporos & pedoporos \\
\hline & Comunicação & fort. comunicantes & fort. comunicantes & fort comunicantes & fort comunicantes \\
\hline & Alisamento & ortoporos & ortoporos & ortoporos & ortoporos \\
\hline \multicolumn{2}{|c|}{$\begin{array}{l}\text { OBSERVAÇÕES GERAIS E } \\
\text { FEIÇÕES PEDOLÓGICAS }\end{array}$} & $\begin{array}{l}\text { domínios com plasma mais con- } \\
\text { centrado isótico (manchas) }\end{array}$ & $\begin{array}{l}\text { faixas horizontais de plasma com } \\
\text { estrut. de base porfinica aberta, do- } \\
\text { mínios com estrut. base mônica }\end{array}$ & $\begin{array}{l}\text { domínios com estrut. de base porfi- } \\
\text { rica estão sendo desmantelados pa- } \\
\text { ra dar origem a estrut. de base enáu- } \\
\text { lica }\end{array}$ & $\begin{array}{l}\text { esqueleto grosseiro (areia média) } \\
\text { encontra-se agrupado }\end{array}$ \\
\hline
\end{tabular}


Continuaçăo do Quadro sintese

\begin{tabular}{|c|c|c|c|c|c|c|c|}
\hline \multicolumn{8}{|c|}{ TRINCHEIRA } \\
\hline \multicolumn{2}{|c|}{$\begin{array}{c}\text { VOLUMES } \\
\text { PROFUNDIDADES }(\mathrm{cm})\end{array}$} & $\begin{array}{c}\text { Areia-franca } \\
5-15\end{array}$ & $\begin{array}{c}\text { Areia } \\
25-35 \\
\end{array}$ & $\begin{array}{c}\text { Areia } \\
55-65 \\
\end{array}$ & $\begin{array}{l}\text { Franco-arenosa } \\
85-95 \\
\end{array}$ & $\begin{array}{c}\text { Areia-franca } \\
115-125\end{array}$ & $\begin{array}{c}\text { Franco-arenosa } \\
170-180\end{array}$ \\
\hline \multirow{3}{*}{$\begin{array}{l}\text { FUNDO } \\
\text { MATRICIAL } \\
(\%)\end{array}$} & Esqueleto & 50 & 60 & 55 & 45 & 50 & 45 \\
\hline & Plasma & 5 & 5 & 5 & 15 & 12 & 15 \\
\hline & Poros & 45 & 35 & 45 & 40 & 38 & 40 \\
\hline \multirow{8}{*}{ ESQUELETO } & Mineralogia & quartzo & quartzo & quartzo & quartzo & quartzo & quartzo \\
\hline & Origem & in situ e transportado & in situ e transportado & in situ e transportado & in situ & in situ & in situ \\
\hline & Dimensão & $\begin{array}{l}\text { areia muito fina a gros- } \\
\text { sa }\end{array}$ & $\begin{array}{l}\text { areia muito fina a gros- } \\
\text { sa }\end{array}$ & $\begin{array}{l}\text { areia muito fina a gors- } \\
\text { sa }\end{array}$ & $\begin{array}{l}\text { areia muito fina a gros- } \\
\text { sa }\end{array}$ & areia muito fina a fina & areia muito fina a fina \\
\hline & Frequência & comum & comum & cumum & comum & comum & comum \\
\hline & Graw/Seleção & pobremente selec. & pobremente selec. & pobremente selec. & pobremente selec. & moderadamente selec. & moderadamente selec. \\
\hline & Dist. base & aleatória e agrupada & aleatória e agrupada & aleatónia e agrupada & aleatória e agrupada & aleatória & aleatória \\
\hline & Dist. ref. & sem & sem & sem & sem & sem & sem \\
\hline & Orientação & fraca a não orientados & fraca a não orientados & fraca a não orientados & não orientados & não orientados & não orientados \\
\hline \multirow{5}{*}{ PLASMA } & Cor & bruno-escura - preta & bruno-avermelhada & bruno-avermelhada & bruno-avermelhada & vermelho-escura & vermelho-escura \\
\hline & Orientação & sem & sem & sem & sem, setores assépicos & sem, setores assépicos & sem, setores sépicos \\
\hline & Dist. base & $\begin{array}{l}\text { mônica e quito-gefúri- } \\
\text { ca }\end{array}$ & quito-gefúrica & quito-gefúrica & quito-gefúrica & quito-gefúrica & quito-gefúrica a enáulica \\
\hline & Dist. ref. & sem & $\begin{array}{l}\text { película ao redor do } \\
\text { esqueleto }\end{array}$ & $\begin{array}{l}\text { película ao redor do } \\
\text { esqueleto }\end{array}$ & \begin{tabular}{|l} 
película ao redor do \\
esqueleto
\end{tabular} & $\begin{array}{l}\text { pelicula ao redor do } \\
\text { esqueleto }\end{array}$ & $\begin{array}{l}\text { película ao redor do } \\
\text { esqueleto }\end{array}$ \\
\hline & $\begin{array}{l}\text { Estruturas Plás- } \\
\text { micas }\end{array}$ & isótico no geral & isótico no geral & isótico no geral & isótico no geral & isótico no geral & isótico no geral \\
\hline \multirow{5}{*}{ POROS } & Tipo & emp. simples, canais & emp. simples & $\begin{array}{l}\text { emp. simples, comple- } \\
\text { xo, cavidades, canais }\end{array}$ & $\begin{array}{l}\text { emp. simples, cavida- } \\
\text { des }\end{array}$ & emp. simples, cavidades & $\begin{array}{l}\text { emp. simples, cavidades, } \\
\text { canais }\end{array}$ \\
\hline & Forma & irregulares & irregulares & irregulares & irregulares & inegulares & irregulares \\
\hline & Origem & pedoporos & pedoporos & pedoporos & pedoporos & pedoporos & pedoporos \\
\hline & Comunicação & fort comunicantes & fort. comunicantes & fort. comunicantes & fort. comunicantes & fort. comunicantes & fort. comunicante \\
\hline & Alisamento & ortoporos & ortoporos & ortoporos & ortoporos & ortoporos & ortoporos \\
\hline \multicolumn{2}{|c|}{$\begin{array}{l}\text { OBSERVAÇÕES GERAIS E } \\
\text { FEIÇÕES PEDOLÓGICAS }\end{array}$} & $\begin{array}{l}\text { esqueleto mais fino e } \\
\text { com mais plasma isóti- } \\
c o \text { preenchendo os } \\
\text { poros }\end{array}$ & $\begin{array}{l}\text { esqueleto mais fino } \\
\text { preenchendo os poros }\end{array}$ & $\begin{array}{l}\text { contato visível entre } \\
\text { esqueleto fino e gros- } \\
\text { seiro }\end{array}$ & $\begin{array}{l}\text { plasma associado ao } \\
\text { esqueleto mais fino }\end{array}$ & $\begin{array}{l}\text { a estrut. de base porfíica } \\
\text { aberta está sendo trans- } \\
\text { formada em enáulica }\end{array}$ & $\begin{array}{l}\text { microagregação abun- } \\
\text { dante estrutura de base } \\
\text { enáulica }\end{array}$ \\
\hline
\end{tabular}


ANEXO 3

Composição granulométrica das formações superficiais 
Toposseqüência do sítio Três Leões 


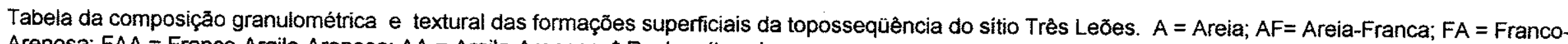
Arenosa; $F A A=$ Franco-Argilo-Arenosa; $A A=$ Argila-Arenosa; ${ }^{*}$ Rocha alterada

\begin{tabular}{|c|c|c|c|c|c|c|c|c|c|c|c|c|c|}
\hline \multirow{2}{*}{ Amostra } & \multirow{2}{*}{ Prof. $(\mathrm{cm})$} & \multicolumn{10}{|c|}{ Granulometria (ø) - Teores em \% } & \multirow{2}{*}{$\begin{array}{l}\text { Silte / } \\
\text { Argila }\end{array}$} & \multirow{2}{*}{ Textura } \\
\hline & & 1,00 & 1,50 & 2,00 & 2,50 & 3,00 & 3,50 & 4,00 & 5,00 & 7,00 & 9,00 & & \\
\hline TRI -1 & $0,0-20$ & 0,09 & 0,80 & 6,17 & 42,08 & 22,19 & 8,15 & 2,53 & 1,24 & 2,47 & 14,28 & 0,26 & FA \\
\hline TRI -2 & $20-32$ & 0,14 & 0,73 & 6,27 & 45,86 & 20,97 & 6,71 & 2,37 & 2,13 & 0,62 & 14,20 & 0,19 & FA \\
\hline TRI -3 & $32-60$ & 0,06 & 0,67 & 5,87 & 41,21 & 20,75 & 7,71 & 2,60 & 1,23 & 1,58 & 18,32 & 0,15 & FA \\
\hline TRI -4 & $60-155$ & 0,05 & 0,48 & 478,00 & 37,08 & 20,37 & 7,43 & 2,72 & 1,34 & 2,10 & 23,65 & 0,15 & FAA \\
\hline TRI -5 & $155-200+$ & 0,06 & 0,59 & 5,98 & 39,15 & 19,90 & 6,98 & 2,41 & 1,53 & 2,63 & 20,77 & 0,20 & FAA \\
\hline TRII - 1 & $0,0-18$ & 0,22 & 1,25 & 5,26 & 34,05 & 27,92 & 12,94 & 4,25 & 2,16 & 2,40 & 9,55 & 0,48 & $\mathrm{AF}$ \\
\hline TRII - 2 & $18-35$ & 0,09 & 0,89 & 4,14 & 33,27 & 28,04 & 14,00 & 5,21 & 1,54 & 1,70 & 11,12 & 0,29 & AF \\
\hline TRII - 3 & $35-120$ & 0,08 & 0,67 & 3,33 & 26,38 & 23,18 & 11,21 & 4,25 & 3,43 & 2,47 & 25,00 & 0,23 & FAA \\
\hline TRII - 4 & $120-155$ & 0,09 & 0,67 & 3,35 & 24,29 & 22,94 & 11,03 & 4,36 & 2,30 & 3,55 & 27,42 & 0,21 & FAA \\
\hline TRII - 5 & $155-200+$ & 0,10 & 0,79 & 3,85 & 28,12 & 23,42 & 11,85 & 4,36 & 0,34 & 6,15 & 21,02 & 0,30 & FAA \\
\hline TRIII - 1 & $0,0-20$ & 0,48 & 1,25 & 4,85 & 33,18 & 26,92 & 12,17 & 4,50 & 1,38 & 3,00 & 12,27 & 0,36 & AF \\
\hline TRIII - 2 & $20-45$ & 0,41 & 1,24 & 4,45 & 36,36 & 28,13 & 13,43 & 4,88 & 2,99 & 1,55 & 6,55 & 0,69 & AF \\
\hline TRIII - 3 & $45-65$ & 0,28 & 1,12 & 4,37 & 33,13 & 25,08 & 7,04 & 4,64 & 2,99 & 2,23 & 19,12 & 0,27 & $\mathrm{FA}$ \\
\hline TRIII - 4 & $65-170$ & 0,12 & 0,61 & 4,20 & 30,35 & 22,59 & 7,94 & 3,15 & 3,26 & 1,23 & 32,05 & 0,14 & FAA \\
\hline TRIII - 5 & $170-200+$ & 0,11 & 0,94 & 3,84 & 27,88 & 22,02 & 10,14 & 4,04 & 0,76 & 3,47 & 26,80 & 0,16 & FAA \\
\hline Banda V2 & 40 & 0.08 & 0.46 & 3.79 & 28.39 & 26.38 & 13.55 & 5.75 & 2.20 & 265 & 16.75 & 0.29 & EA \\
\hline
\end{tabular}


Continuação da Tabela

\begin{tabular}{|c|c|c|c|c|c|c|c|c|c|c|c|c|c|}
\hline \multirow{2}{*}{ Amostra } & \multirow{2}{*}{ Prof. $(\mathrm{cm})$} & \multicolumn{10}{|c|}{ Granulometria (ø) - Teores em \% } & \multirow{2}{*}{$\begin{array}{l}\text { Silte I } \\
\text { Argila }\end{array}$} & \multirow{2}{*}{ Textura } \\
\hline & & 1,00 & 1,50 & 2,00 & 2,50 & 3,00 & 3,50 & 4,00 & 5,00 & 7,00 & 9,00 & & \\
\hline TRIV-1 & $0,0-15$ & 0,18 & 0,83 & 5,37 & 24,53 & 31,83 & 16,19 & 6,84 & 2,35 & 3,92 & 7,52 & 0,83 & AF \\
\hline TRIV-2 & $15-25$ & 1,41 & 0,04 & 5,64 & 26,22 & 31,52 & 16,74 & 7,31 & 0,60 & 3,40 & 7,22 & 0,55 & AF \\
\hline TRIV-3 & $25-82$ & 1,23 & 0,91 & 3,77 & 17,46 & 19,84 & 13,41 & 6,80 & 4,76 & 3,45 & 28,37 & 0,29 & FAA \\
\hline TRIV-4 & $82-100$ & 0,53 & 0,54 & 3,76 & 11,84 & 17,16 & 13,05 & 9,79 & 4,78 & 5,32 & 33,77 & 0,30 & AA \\
\hline TRIV-5 & $100-200+$ & 0,08 & 0,64 & 6,49 & 13,93 & 19,69 & 13,26 & 8,15 & 4,28 & 9,67 & 24,45 & 0,57 & FAA \\
\hline TRV -1 & $0,0-10$ & $\cdots$ & 0,44 & 3,90 & 25,57 & 31,84 & 17,96 & 6,66 & 1,83 & 3,55 & 8,25 & 0,65 & $\mathrm{AF}$ \\
\hline TRV - 2 & $10-60$ & 0,50 & 0,37 & 5,69 & 24,23 & 33,04 & 19,84 & 6,88 & 3,00 & 1,68 & 4,77 & 0,98 & A \\
\hline TRV -3 & $60-75$ & 0,18 & 0,21 & 3,06 & 19,44 & 33,83 & 17,89 & 7,44 & 2,37 & 1,40 & 14,17 & 0,27 & FA \\
\hline TRV - 4 & $75-110$ & 0,10 & 0,13 & 0,81 & 12,65 & 29,00 & 15,04 & 6,26 & 4,99 & 8,75 & 22,37 & 0,61 & FAA * \\
\hline TRV - 5 & $110-200+$ & $\ldots$ & 0.06 & 0.94 & 19.34 & 30.01 & 13.12 & 5.70 & 2.36 & 10.77 & 17.70 & 0.74 & $F A *$ \\
\hline
\end{tabular}


Toposseqüência de Sumaré 


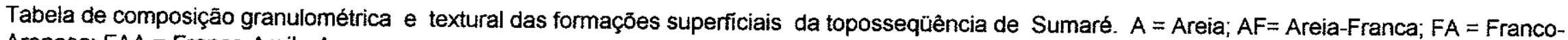
Arenosa; FAA = Franco-Argilo-Arenosa

\begin{tabular}{|c|c|c|c|c|c|c|c|c|c|c|c|c|c|}
\hline \multirow{2}{*}{ Amostra } & \multirow{2}{*}{ Prof.(cm) } & \multicolumn{10}{|c|}{ Granulometria (o) - Teores em \% } & \multirow{2}{*}{$\begin{array}{l}\text { Sitte / } \\
\text { Argila }\end{array}$} & \multirow{2}{*}{ Textura } \\
\hline & & 1,00 & 1,50 & 2,00 & 2,50 & 3,00 & 3,50 & 4,00 & 5,00 & 7,00 & 9,00 & & \\
\hline TR $1-0$ & 0,0 & 10,57 & 10,31 & 18,88 & 29,14 & 14,68 & 4,07 & 1,00 & 1,23 & 1,30 & 8,82 & 0,27 & AF \\
\hline TR I - 1 & $0,0-20$ & 8,98 & 8,45 & 17,42 & 29,66 & 15,35 & 4,50 & 1,22 & 0,33 & 2,92 & 11,17 & 0,29 & AF \\
\hline TR $\mid-2$ & $20-80$ & 6,27 & 7,39 & 16,06 & 27,97 & 15,68 & 4,95 & 1,57 & 1,09 & 2,02 & 17,00 & 0,18 & FA \\
\hline TR I - 3 & $80-120$ & 8,20 & 9,30 & 16,04 & 25,78 & 13,48 & 4,31 & 1,61 & 1,76 & 3,46 & 17,82 & 0,19 & FA \\
\hline TR I - 4 & $120-160$ & 8,37 & 8,43 & 15,87 & 25,44 & 14,17 & 4,43 & 1,56 & 1,93 & 3,49 & 18,04 & 0,19 & FA \\
\hline TRI - 5 & $160-200+$ & 9,60 & 8,40 & 15,20 & 25,10 & 13,50 & 4,89 & 1,80 & 1,09 & 2,30 & 18,12 & 0,19 & FA \\
\hline TRVII -1 & $0,0-15$ & 1,72 & 6,98 & 22,74 & 33,09 & 18,28 & 6,55 & 1,45 & 0,05 & 2,17 & 6,97 & 0,32 & A \\
\hline TVII- 2 & $15-55$ & 2,54 & 5,45 & 17,55 & 27,74 & 18,06 & 8,43 & 2,52 & 0,21 & 2,40 & 15,10 & 0,17 & FA \\
\hline TRVII-3 & $55-70$ & 2,20 & 5,45 & 17,54 & 25,76 & 16,72 & 7,21 & 1,20 & 0,99 & 1,55 & 20,15 & 0,13 & FAA \\
\hline TRVII-4 & $70-100+$ & 1,97 & 5,67 & 16,93 & 25,14 & 16,68 & 6,82 & 2,46 & 0,67 & 1,75 & 22,58 & 0,08 & FAA \\
\hline TRVI - 0 & 0,0 & 1,50 & 7,04 & 23,30 & 29,72 & 20,25 & 8,58 & 2,39 & 0,28 & 2,12 & 4,82 & 0,50 & FAA \\
\hline TRVI - 1 & $0,0-30$ & 1,92 & 8,04 & 23,83 & 27,10 & 15,58 & 6,39 & 1,77 & 1,67 & 2,90 & 10,80 & 0,42 & $\mathrm{AF}$ \\
\hline TRVI - 2 & $30-60$ & 1,38 & 6,29 & 21,52 & 26,38 & 16,29 & 7,15 & 2,27 & 2,15 & 2,30 & 14,27 & 0,31 & FA \\
\hline TRVI - 3 & $60-115$ & 1,08 & 6,23 & 20,46 & 24,88 & 14,75 & 6,37 & 2,14 & 0,60 & 1,72 & 21,77 & 0,11 & FAA \\
\hline TRVI - 4 & $115-200+$ & 1,65 & 7,35 & 21,98 & 24,55 & 13,57 & 6,30 & 2,25 & 1,05 & 1,50 & 19,80 & 0,13 & FA \\
\hline TRVIII-0 & 0,0 & 0,62 & 4,42 & 22,59 & 31,28 & 20,35 & 8,82 & 2,46 & 0,59 & 0,42 & 8,45 & 0,12 & A \\
\hline TRVIII-1 & $0,0-35$ & 0,43 & 3,92 & 23,43 & 30,20 & 17,79 & 7,55 & 1,98 & 0,78 & 1,40 & 12,52 & 0,17 & AF \\
\hline TRVIII-2 & $35-65$ & 0.78 & 5.28 & 23.56 & 27.03 & 14,69 & 6.41 & 2.00 & 1.85 & 0.70 & 17.70 & 0.14 & FA \\
\hline
\end{tabular}


Continuação da Tabela

\begin{tabular}{|c|c|c|c|c|c|c|c|c|c|c|c|c|c|}
\hline \multirow{2}{*}{ Amostra } & \multirow{2}{*}{ Prof.(cm) } & \multicolumn{10}{|c|}{ Granulometria (๑) - Teores em \% } & \multirow{2}{*}{$\begin{array}{l}\text { Silte I } \\
\text { Argila }\end{array}$} & \multirow{2}{*}{ Textura } \\
\hline & & 1,00 & 1,50 & 2,00 & 2,50 & 3,00 & 3,50 & 4,00 & 5,00 & 7,00 & 9,00 & & \\
\hline TRVIII-3 & $65-90$ & 1,22 & 6,59 & 24,96 & 25,26 & 12,99 & 5,22 & 1,78 & 0,86 & 1,50 & 19,62 & 0,12 & FA \\
\hline TRVill-4 & $90-150+$ & 0,96 & 6,04 & 24,25 & 25,42 & 12,68 & 5,70 & 2,04 & 0,06 & 0,55 & 22,30 & 0,03 & FAA \\
\hline$T R \|-0$ & 0,0 & 1,22 & 6,59 & 25,66 & 34,60 & 18,45 & 5,78 & 1,30 & 0,88 & 2,10 & 3,42 & 0,87 & A \\
\hline TR $\|-1$ & $0,0-20$ & 0,54 & 5,78 & 22,59 & 32,64 & 19,65 & 6,05 & 1,48 & 2,43 & 1,52 & 7,32 & 0,54 & $\mathrm{AF}$ \\
\hline TR $\|-2$ & $20-90$ & 0,37 & 4,52 & 19,57 & 31,17 & 19,25 & 6,64 & 1,92 & 1,24 & 1,60 & 13,72 & 0,21 & $\mathrm{AF}$ \\
\hline TR II - 2 & $20-90$ & 0,15 & 3,16 & 17,09 & 30,88 & 20,60 & 8,26 & 2,67 & 1,17 & 3,12 & 12,90 & 0,33 & $\mathrm{AF}$ \\
\hline T Rll - 3 & $90-130$ & 0,39 & 5,35 & 20,67 & 29,22 & 16,38 & 5,69 & 1,80 & 0,57 & 1,13 & 18,80 & 0,09 & FA \\
\hline TR II - 4 & $130-160$ & 0,36 & 2,72 & 15,45 & 28,75 & 19,98 & 8,32 & 3,06 & 0,36 & 1,35 & 19,65 & 0,09 & FA \\
\hline TR $\|-5$ & $160-200+$ & 0,13 & 3,71 & 17,42 & 29,34 & 19,35 & 7,56 & 2,68 & 0,84 & 1,47 & 17,50 & 0,13 & FA \\
\hline T Rll - 1 & $0,0-10$ & 0,31 & 8,45 & 35,07 & 30,63 & 12,44 & 4,25 & 0,96 & 0,07 & 2,65 & 5,17 & 0,53 & A \\
\hline TR Ill -2 & $10-40$ & 0,46 & 5,56 & 29,25 & 30,02 & 15,96 & 5,62 & 1,41 & 0,25 & 2,30 & 9,17 & 0,28 & $\mathrm{AF}$ \\
\hline TR III -3 & $40-90$ & 0,24 & 3,41 & 21,25 & 29,63 & 19,44 & 8,59 & 2,73 & 1,66 & 1,30 & 11,75 & 0,25 & $\mathrm{AF}$ \\
\hline T RI!|- 4 & $90-150$ & 0,15 & 4,51 & 24,67 & 28,71 & 16,32 & 6,71 & 2,14 & 0,40 & 2,22 & 14,17 & 0,18 & $\mathrm{AF}$ \\
\hline TRlli -5 & $150-200+$ & 0.05 & 4,32 & 23.98 & 29.12 & 16.83 & 763 & 2.20 & 0.30 & 2.10 & 13.47 & 0.18 & $F A$ \\
\hline
\end{tabular}




\begin{tabular}{|c|c|c|c|c|c|c|c|c|c|c|c|c|c|}
\hline \multirow{2}{*}{ Amostra } & \multirow{2}{*}{ Prof.(cm) } & \multicolumn{10}{|c|}{ Granulometria (ø) - Teores em \% } & \multirow{2}{*}{$\begin{array}{l}\text { Silte I } \\
\text { Argila }\end{array}$} & \multirow{2}{*}{ Textura } \\
\hline & & 1,00 & 1,50 & 2,00 & 2,50 & 3,00 & 3,50 & 4,00 & 5,00 & 7,00 & 9,00 & & \\
\hline TRIV - 1 & $0,0-20$ & 1,36 & 11,38 & 32,69 & 27,85 & 11,14 & 4,32 & 1,12 & 1,20 & 2,12 & 6,82 & 0,47 & A \\
\hline TRIV - 2 & $20-50$ & 0,78 & 8,39 & 30,39 & 28,49 & 11,84 & 4,19 & 1,14 & 0,28 & 2,10 & 12,40 & 0,19 & AF \\
\hline TRIV - 3 & $50-95$ & 0,80 & 10,16 & 31,65 & 25,56 & 10,25 & 3,88 & 1,26 & 0,55 & 2,07 & 13,82 & 0,19 & $\mathrm{AF}$ \\
\hline TRIV-3/4 & $50-95$ & 1,43 & 10,23 & 3007 & 24,69 & 9,88 & 3,89 & 1,20 & 0,99 & 2,20 & 15,42 & 0,21 & FA \\
\hline TRIV - 4 & $95-150$ & 1,07 & 10,28 & 30,38 & 24,89 & 9,49 & 3,58 & 1,33 & 1,63 & 1,30 & 16,05 & 0,18 & FA \\
\hline TRIV - 5 & $150-200+$ & 1,05 & 9,74 & 30,86 & 25,97 & 10,35 & 3,86 & 1,23 & 2,05 & 1,37 & 13,52 & 0,25 & AF \\
\hline TRV -1 & $0,0-20$ & 0,58 & 7,09 & 27,71 & 28,5 & 16,46 & 6,97 & 1,79 & 0,35 & 1,85 & 8,70 & 0,25 & AF \\
\hline TRV - 2 & $20-35$ & 0,76 & 9,99 & 31,35 & 26,41 & 12,71 & 4,80 & 1,24 & 1,59 & 1,20 & 9,95 & 0,28 & AF \\
\hline TRV - 3 & $35-80$ & 0,47 & 7,67 & 28,73 & 27,13 & 13,54 & 5,07 & 1,50 & 0,74 & 1,45 & 13,70 & 0,16 & $\mathrm{AF}$ \\
\hline TRV - 4 & $80-200+$ & 0,71 & 8,33 & 29,49 & 26,32 & 13,75 & 5,18 & 1,55 & 0,55 & 1,05 & 13,07 & 0,12 & AF \\
\hline$T R V=4$ & $80-200+$ & 0.87 & 8.91 & 30,06 & 25.47 & 11.69 & 4.33 & 1.30 & 0.25 & 1.97 & 15.15 & 0.15 & FA \\
\hline
\end{tabular}


Toposseqüência de Umuarama 


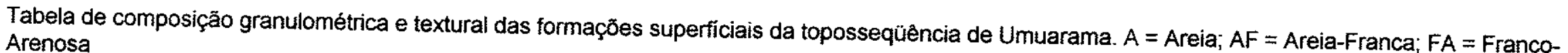

\begin{tabular}{|c|c|c|c|c|c|c|c|c|c|c|c|c|}
\hline \multirow{2}{*}{ Amostra } & \multirow{2}{*}{ Prof.(cm) } & \multicolumn{9}{|c|}{ Granulometria $(\theta)$ - Teores em \% } & \multirow{2}{*}{$\begin{array}{l}\text { Silte I } \\
\text { Argila }\end{array}$} & \multirow{2}{*}{ Textura } \\
\hline & & 1,50 & 2,00 & 2,50 & 3,00 & 3,50 & 4,00 & 5,00 & 7,00 & 9,00 & & \\
\hline TRI - 0 & 0 & 7,75 & 18,57 & 15,58 & 24,67 & 11,27 & 5,02 & 4,10 & 2,67 & 10,37 & 0,65 & $\mathrm{AF}$ \\
\hline TRI - 1 & $0,0-20$ & 7,17 & 17,55 & 16,09 & 24,79 & 10,34 & 4,88 & 4,16 & 1,50 & 13,52 & 0,42 & FA \\
\hline TRI- 2 & $20-50$ & 4,41 & 12,62 & 14,5 & 24,91 & 11,94 & 6,73 & 6,39 & 1,15 & 17,35 & 0,43 & FA \\
\hline TRI - 3 & $50-115$ & 4,49 & 12,82 & 13,08 & 24,34 & 11,34 & 6,71 & 5,55 & 3,32 & 18,35 & 0,48 & FA \\
\hline TR! - 4 & $115-200+$ & 3,83 & 11,2 & 13,56 & 24,93 & 12,15 & 7,25 & 5,64 & 1,22 & 20,22 & 0,34 & FA \\
\hline TRII - 0 & $0-0$ & 8,26 & 28,16 & 17,27 & 22,99 & 8,96 & 3,32 & 3,67 & 2,50 & 4,87 & 1,27 & A \\
\hline TRII - 1 & $0,0-26$ & 3,91 & 16,3 & 16,11 & 30,49 & 14,06 & 6,27 & 4,19 & 1,37 & 7,30 & 0,76 & AF \\
\hline TRII - 2 & $26-75$ & 3,85 & 16,46 & 14,69 & 26,81 & 13,61 & 7,20 & 3,54 & 2,42 & 11,42 & 0,52 & $\mathrm{AF}$ \\
\hline TRII - 2 & $26-75$ & 4,11 & 15,55 & 13,66 & 24,39 & 12,49 & 6,97 & 3,81 & 1,57 & 17,45 & 0,31 & FA \\
\hline TRII - 3 & $75-150$ & 3,61 & 14,74 & 13,93 & 24,67 & 12,83 & 7,21 & 3,19 & 1,57 & 18,25 & 0,26 & FA \\
\hline TRU - 4 & $150-200+$ & 3,32 & 14,54 & 13,68 & 34,87 & 12,33 & 7,06 & 5,40 & 0,75 & 18,05 & 0,34 & FA \\
\hline TRII - 5 & $150-200 t$ & 3,04 & 14.19 & 12.98 & 24.88 & 13,14 & 7.51 & 4,87 & 2.02 & 17.37 & 0.40 & FA \\
\hline
\end{tabular}




\begin{tabular}{|c|c|c|c|c|c|c|c|c|c|c|c|c|}
\hline \multirow{2}{*}{ Amostra } & \multirow{2}{*}{ Prof.(cm) } & \multicolumn{9}{|c|}{ Granulometria (Ø) - Teores em \% } & \multirow{2}{*}{$\begin{array}{l}\text { Silte I } \\
\text { Argila }\end{array}$} & \multirow{2}{*}{ Textura } \\
\hline & & 1,50 & 2,00 & 2,50 & 3,00 & 3,50 & 4,00 & 5,00 & 7,00 & 9,00 & & \\
\hline TRIV- 0 & 0 & 8,76 & 36,75 & 16,74 & 20,37 & 7,42 & 2,72 & 2,84 & 0,20 & 4,20 & 0,72 & A \\
\hline TRIV - 1 & $0,0-30$ & 4,15 & 25,79 & 16,73 & 25,74 & 10,69 & 5,89 & 2,74 & 2,17 & 6,10 & 0,80 & A \\
\hline TRIV - 2 & $30-130$ & 3,47 & 22,95 & 15,12 & 23,25 & 10,28 & 6,72 & 3,89 & 2,20 & 12,12 & 0,50 & AF \\
\hline TRIV - 3 & $130-160$ & 3,41 & 25,13 & 15,96 & 23,09 & 10,20 & 5,68 & 0,44 & 2,47 & 13,62 & 0,21 & $\mathrm{AF}$ \\
\hline TRIV - 4 & $160-200+$ & 4,58 & 26,53 & 13,64 & 19,54 & 7,91 & 5,05 & 4,65 & 1,20 & 16,90 & 0,35 & FA \\
\hline TRIIIC-1 & $0,0-15$ & 7,22 & 31,63 & 15,82 & 20,63 & 8,97 & 4,56 & 3,42 & 2,10 & 5,65 & 0,97 & $\mathrm{AF}$ \\
\hline TRIIC-2 & $15-50$ & 2,13 & 22,22 & 22,77 & 28,67 & 11,9 & 5,15 & 1,16 & 1,80 & 4,20 & 0,70 & A \\
\hline TRIIIC-3 & $50-74$ & 6,92 & 36,06 & 18,38 & 22,09 & 7,47 & 2,58 & 2,08 & 1,35 & 3,07 & 1,18 & A \\
\hline TRIIIC-4 & $74-85$ & 5,47 & 24,45 & 17,25 & 21,26 & 7,84 & 4,66 & 4,05 & 1,77 & 13,25 & 0,44 & FA \\
\hline TRIII - 5 & $85-95$ & 3,01 & 30,45 & 20,67 & 20,88 & 8,42 & 4,24 & 3,83 & 0,95 & 7,55 & 0,63 & $\mathrm{AF}$ \\
\hline TRIII -6 & $95-130$ & 4,55 & 32,98 & 17,93 & 17,24 & 6,15 & 3,44 & 3,59 & 0,45 & 13,67 & 0,30 & $\mathrm{AF}$ \\
\hline TRIII -7 & $130-200+$ & 2.92 & 26.83 & 17.78 & 20.04 & 7.93 & 4.60 & 3.93 & 2.02 & 13.95 & 0.43 & FA \\
\hline
\end{tabular}


ANEXO 4

Parâmetros estatísticos granulométricos de Fol \& Ward (1957) 
Dados das toposseqüências 
Tabela dos parâmetros estatísticos granulométricos da toposseüéncia do sitio Três Leões

\begin{tabular}{|c|c|c|c|c|c|c|}
\hline Amostras & Prof. (cm) & $M_{2} \theta$ & $\delta_{1}$ & $S_{k}$ & $\mathbf{K}_{G}$ & $M_{d} \theta$ \\
\hline TRI-1 & $(00-10)$ & 2.473 & 0.467 & +0.229 & 1.088 & 2.403 \\
\hline TRI-2 & $(20-32)$ & 2.447 & 0.451 & +0.248 & 1.148 & 2.375 \\
\hline TRI-3 & $(32-60)$ & 2.472 & 0.466 & +0.246 & 1.094 & 2.398 \\
\hline TRI-4 & $(60-115)$ & 2.489 & 0.463 & +0.250 & 1.053 & 2.420 \\
\hline TRI-5 & $(115-200+)$ & 2.475 & 0.458 & +0.241 & 1.076 & 2.407 \\
\hline Média & & 2.471 & 0.461 & +0.243 & 1.092 & 2.401 \\
\hline TRII-1 & $(00-18)$ & 2.592 & 0.520 & +0.132 & 1.003 & 2.5539 \\
\hline TRII-2 & $(18-35)$ & 2.635 & 0.523 & +0.176 & 0.968 & 2.579 \\
\hline TRII-3 & $(35-120)$ & 2.639 & 0.522 & +0.167 & 0.973 & 2.588 \\
\hline TRII-4 & $(120-155)$ & 2.652 & 0.532 & +0.144 & 0.996 & 2.608 \\
\hline TRII-5 & $(155-200+)$ & 2.630 & 0.530 & 0.165 & 0.983 & 2.572 \\
\hline Média & & 2.630 & 0.525 & +0.157 & 0.985 & 2.577 \\
\hline TRHI-1 & $(00-20)$ & 2.591 & 0.529 & +0.142 & 1.034 & 2.536 \\
\hline TRIII-2 & $(20-45)$ & 2.600 & 0.522 & +0.176 & 1.001 & 2.535 \\
\hline TRIII-3 & $(45-65)$ & 2.524 & 0.500 & +0.176 & 1.134 & 2.484 \\
\hline TRIII-4 & $(65-110)$ & 2.530 & 0.477 & +0.172 & 1.028 & 2.487 \\
\hline TRIII-5 & $(110-200+)$ & 2.601 & 0.528 & +0.177 & 1.018 & 2.539 \\
\hline Média & & 2.569 & 0.511 & +0.168 & 1.043 & 2.516 \\
\hline TRIV-1 & $(00-15)$ & 2.708 & 0.569 & +0.057 & 1.039 & 2.688 \\
\hline TRIV-2 & $(15-25)$ & 2.701 & 0.582 & +0.062 & 1.035 & 2.676 \\
\hline TRIV-3 & $(25-82)$ & 2.736 & 0.636 & +0.026 & 0.995 & 2.710 \\
\hline TRIV-4 & $(82-100)$ & 2.862 & 0.652 & +0.000 & 0.924 & 2.848 \\
\hline TRIV 5 & $(100-200+)$ & 2.772 & 0.649 & +0.009 & 0.950 & 2.762 \\
\hline Média & & 2.756 & 0.618 & +0.031 & 0.989 & 2.737 \\
\hline TRV-1 & $(00-10)$ & 2.732 & 0.533 & +0.107 & 0.921 & 2.708 \\
\hline TRV-2 & $(10-60)$ & 2.730 & 0.566 & +0.029 & 0.983 & 2.719 \\
\hline TRV-3 & $(60.75)$ & 2.786 & 0.532 & +0.085 & 1.006 & 2.768 \\
\hline TRV -4 & $(75-110)$ & 2,849 & 0.502 & +0.109 & 1.069 & 2.815 \\
\hline TRV-5 & $(110-160+)$ & 2.764 & 0.506 & +0.127 & 1.051 & 2.737 \\
\hline Média & & 2.772 & 0.528 & +0.091 & 1.006 & 2.749 \\
\hline
\end{tabular}


Tabela dos parâmetros estatísticos granulométricos da toposseqüência de Sumaré

\begin{tabular}{|c|c|c|c|c|c|c|}
\hline Amostras & Prof. $(\mathrm{cm})$ & $M_{z} \theta$ & $\delta_{i}$ & $\mathbf{S}_{k}$ & $K_{g}$ & $M_{d} \theta$ \\
\hline TRI-O & $(0.0)$ & 1.981 & 0.737 & -0.174 & 1.050 & 1.981 \\
\hline TRI-1 & $(0.0-20)$ & 2.051 & 0.732 & -0.161 & 1.127 & 2.134 \\
\hline TRI - 2 & $(20-80)$ & 2.141 & 0.709 & -0.106 & 1.142 & 2.183 \\
\hline TRI - 3 & $(80-120)$ & 2.034 & 0.756 & -0.129 & 1.101 & 2.113 \\
\hline TRl - 4 & $(120-160)$ & 2.051 & 0.764 & -0.130 & 1.102 & 2.129 \\
\hline TRl - 5 & $(160-200+)$ & 2.026 & 0.792 & -0.137 & 1.092 & 2.120 \\
\hline Média & & 2.047 & 0.748 & -0.140 & 1.102 & 2.110 \\
\hline TRVII - 1 & $(0.0-15)$ & 2.220 & 0.611 & +0.022 & 1.070 & 2.211 \\
\hline TRVII - 2 & $(15-55)$ & 2.289 & 0.665 & +0.006 & 1.059 & 2.281 \\
\hline TRVII - 3 & $(55-70)$ & 2.255 & 0.644 & 0.000 & 1.037 & 2.249 \\
\hline TRVII-4 & $(70-150+)$ & 2.270 & 0.661 & +0.015 & 1.047 & 2.264 \\
\hline Média & & 2.259 & 0.645 & +0.011 & 1.053 & 2.251 \\
\hline TRVI - 0 & $(0.0)$ & 2.261 & 0.642 & +0.044 & 0.995 & 2.245 \\
\hline TRVI-1 & $(0.0-30)$ & 2.187 & 0.641 & +0.067 & 1.046 & 2.157 \\
\hline TRVI - 2 & $(30-60)$ & 2.244 & 0.644 & +0.067 & 1.016 & 2.217 \\
\hline TRVI-3 & $(60-115)$ & 2.233 & 0.641 & +0.075 & 1.026 & 2.205 \\
\hline TRVI - 4 & $(115-200+)$ & 2.198 & 0.656 & +0.091 & 1.054 & 2.160 \\
\hline Média & & 2.225 & 0.645 & +0.069 & 1.027 & 2.197 \\
\hline TRVIII - 0 & $(0.0)$ & 2.304 & 0.597 & +0.095 & 0.957 & 2.282 \\
\hline TRVIII-1 & $(0.0-35)$ & 2.276 & 0.578 & +0.131 & 0.945 & 2.246 \\
\hline TRVIII - 2 & $(35-65)$ & 2.228 & 0.612 & 0.113 & 1.029 & 2.190 \\
\hline TRVIII - 3 & $(65-90)$ & 2.169 & 0.616 & +0.117 & 1.094 & 2.124 \\
\hline TRVIII - 4 & $(90-150+)$ & 2.191 & 0.621 & +0.129 & 1.087 & 2.143 \\
\hline Média & & 2.234 & 0.605 & +0.117 & 1.022 & 2.197 \\
\hline TRII-0 & $(0.0)$ & 2.206 & 0.581 & +0.039 & 1.057 & 2.193 \\
\hline TRII - 1 & $(0.0-20)$ & 2.247 & 0.580 & +0.045 & 1.013 & 2.237 \\
\hline TRII - 2 & $(20-90)$ & 2.290 & 0.579 & +0.068 & 1.013 & 2.277 \\
\hline TRII - 2 & $(20-90)$ & 2.359 & 0.575 & +0.089 & 1.015 & 2.342 \\
\hline TRाI-3 & $(90-130)$ & 2.246 & 0.592 & +0.070 & 1.037 & 2.228 \\
\hline TRII - 4 & $(130-160)$ & 2.380 & 0.582 & +0.089 & 1.018 & 2.362 \\
\hline TR\| - 5 & $(160-200+)$ & 2.337 & 0.583 & +0.093 & 1.000 & 2.321 \\
\hline Média & & 2.295 & 0.582 & +0.070 & 1.022 & 2.280 \\
\hline TRIII - 1 & $(0.0-10)$ & 2.080 & 0.533 & +0.132 & 1.051 & 2.036 \\
\hline TRI|| - 2 & $(10-40)$ & 2.188 & 0.569 & +0.131 & 1.020 & 2.148 \\
\hline TRIII - 3 & $(40-90)$ & 2.325 & 0.589 & +0.118 & 0.940 & 2.299 \\
\hline TRIII - 4 & $(90-150)$ & 2.251 & 0.586 & +0.143 & 0.968 & 2.214 \\
\hline TRtH - 5 & $(150-200+)$ & 2.272 & 0.587 & +0.146 & 0.944 & 2.235 \\
\hline Média & & 2.223 & 0.573 & +0.134 & 0.985 & 2.186 \\
\hline TRIV-1 & $(0.0-20)$ & 2.039 & 0.567 & +0.131 & 1.084 & 1.992 \\
\hline TRIV - 2 & $(20-50)$ & 2.092 & 0.560 & +0.113 & 1.081 & 2.054 \\
\hline TRIV - 3 & $(50-95)$ & 2.041 & 0.562 & +0.158 & 1.091 & 1.987 \\
\hline TRIV $-3 / 4$ & $(50-95)$ & 2.035 & 0.572 & +0.146 & 1.099 & 1.983 \\
\hline TRIV -4 & $(95-150)$ & 2.027 & 0.562 & +0.145 & 1.100 & 1.980 \\
\hline TRIV - 5 & $(150-200+)$ & 2.047 & 0.563 & +0.142 & 1.093 & 1.998 \\
\hline Média & & 2.047 & 0.564 & +0.139 & 1.091 & 1.999 \\
\hline TRV -1 & $(0.0-20)$ & 2.204 & 0.612 & +0.118 & 1.010 & 2.161 \\
\hline TRV -2 & $(20-35)$ & 2.090 & 0.586 & +0.154 & 1.068 & 2.029 \\
\hline TRV -3 & $(35-80)$ & 2.145 & 0.590 & +0.136 & 1.075 & 2.096 \\
\hline TRV -4 & $(80-160)$ & 2.135 & 0.599 & +0.145 & 1.070 & 2.079 \\
\hline TRV - 4 & $(160-200+)$ & 2.088 & 0.582 & +0.154 & 1.083 & 2.029 \\
\hline Média & & 2.132 & 0,594 & +0.141 & 1.061 & 2.079 \\
\hline
\end{tabular}


Tabela dos parâmetros estatísiticos granulométricos da toposseqüência de Umuarama

\begin{tabular}{|c|c|c|c|c|c|c|}
\hline Amostras & Prof. (cm) & $\mathrm{M}_{2} \theta$ & $\delta_{1}$ & $S_{k}$ & $\mathrm{~K}_{\mathrm{G}}$ & $M_{d} \theta$ \\
\hline TR I - 0 & $(0.0)$ & 2.423 & 0.723 & -0.088 & 0.896 & 2.485 \\
\hline TR I - 1 & $(0.0-20)$ & 2.421 & 0.711 & -0.093 & 0.919 & 2.488 \\
\hline TRI - 2 & $(20-50)$ & 2.567 & 0.717 & -0.076 & 1.003 & 2.621 \\
\hline TRI - 3 & $(50-115)$ & 2.562 & 0.728 & -0.086 & 0.989 & 2.623 \\
\hline TR † -4 & $(115-200+)$ & 2.609 & 0.711 & -0.070 & 1.001 & 2.658 \\
\hline Média & & 2.516 & 0.718 & -0.080 & 0.916 & 2.5675 \\
\hline$T R \|-0$ & $(0.0)$ & 2.266 & 0.666 & +0.091 & 0.858 & 2.233 \\
\hline T R\| - 1 & $(0.0-26)$ & 2.551 & 0.679 & -0.088 & 0.945 & 2.619 \\
\hline T Rll - 2 & $(26-75)$ & 2.560 & 0.708 & -0.061 & 0.909 & 2.618 \\
\hline T RH - 2 & $(26-75)$ & 2.553 & 0.721 & -0.060 & 0.907 & $2 . .608$ \\
\hline TRII - 3 & $(75-150)$ & 2.574 & 0.713 & -0.054 & 0.913 & 2.032 \\
\hline TR॥ - 4 & $(150-200+)$ & 2.575 & 0.709 & -0.055 & 0.928 & 2.628 \\
\hline $\operatorname{TR} \|-4$ & $(150-200+)$ & 2.599 & 0.713 & -0.062 & 0.911 & 2.654 \\
\hline Média & & 2.525 & 0.701 & -0.041 & 0.910 & 2.485 \\
\hline TRIV - 0 & $(0.0)$ & 2.164 & 0.645 & +0.298 & 0.878 & 2.026 \\
\hline T RIV - 1 & $(0.0-30)$ & 2.413 & 0.674 & +0.038 & 0.835 & 2.435 \\
\hline T RIV - 2 & $(30-130)$ & 2.461 & 0.701 & +0.037 & 0.846 & 2.480 \\
\hline TRIV - 3 & $(130-160)$ & 2.412 & 0.677 & +0.074 & 0.831 & 2.413 \\
\hline T RIV - 4 & $(160-200+)$ & 2.320 & 0.681 & +0.159 & 0.849 & 2.275 \\
\hline Media & & 2.354 & 0.676 & +0.121 & 0.848 & 2.326 \\
\hline TR II - 1 & $(0.0-15)$ & 2.257 & 0.677 & +0.195 & 0.859 & 2.176 \\
\hline TR III - 2 & $(15-50)$ & 2.454 & 0.628 & 0.000 & 0.889 & 2485 \\
\hline$T \| 1-3$ & $(50-74)$ & 2.166 & 0.603 & +0.252 & 0.862 & 2.062 \\
\hline TR \|\|$-4$ & $(74-85)$ & 2.316 & 0.667 & +0.085 & 0.886 & 2.306 \\
\hline TR III - 5 & $(85-95)$ & 2.300 & 0.620 & +0.187 & 0.834 & 2.251 \\
\hline TRII - 6 & $(95-130)$ & 2.209 & 0.618 & +0.303 & 0.870 & 2.101 \\
\hline TRIII -7 & $(130-200+)$ & 2.322 & 0.637 & +0.161 & 0.843 & 2.290 \\
\hline Média & & 2.289 & 0.636 & +0.169 & 0.863 & 2.239 \\
\hline
\end{tabular}


Dados do Arenito Caiuá 
Tabela dos parâmetros estatísticos granulométricos obtidos de 18 amostras do Arenito Caiuá, no extremo oeste do estado de Såo Paulo. * Sedimentos cenozóicos coletados sobre a Formaçăo Bauru; *» sobre a Formação Caiuá (Suarez, 1975)

\begin{tabular}{|c|c|c|c|c|c|}
\hline Amostra & $M_{z} \theta$ & $\delta_{1}$ & $S_{k}$ & $\mathrm{~K}_{\mathrm{g}}$ & $M_{d} \theta$ \\
\hline$S R-1$ & 2,080 & 0,783 & $+0,450$ & 0,916 & 2,00 \\
\hline $\mathrm{MD}-1$ & 0,948 & 0,941 & $+0,470$ & 2,210 & 0,85 \\
\hline Eucl. -39 & 1,630 & 0,307 & $+0,260$ & 1,400 & 1,60 \\
\hline EE-51 & 1,530 & 0,757 & $+2,690$ & 2,690 & 1,50 \\
\hline EE - 56(M.Andrade) & 2,280 & 1,422 & $+0,250$ & 1,410 & 2,20 \\
\hline PS-1 & 0,920 & 0,948 & $+0,520$ & 4,680 & 0,85 \\
\hline S - 6 & 2,510 & 1,750 & $+0,208$ & 1,240 & 2,51 \\
\hline Ps - 7 & 2,570 & 1,790 & $+0,012$ & 0,990 & 2,85 \\
\hline Pedregulho & 2,450 & 0,943 & $+0,388$ & 2,753 & 2,35 \\
\hline 34 (Porto Alegre) & 1,450 & 0,775 & $+0,120$ & 0,694 & 1,40 \\
\hline $42(\mathrm{Km} 839 \mathrm{RD})$ & 2,080 & 1,247 & $+0,450$ & 2,050 & 1,90 \\
\hline 46 (Faz. Pontal) & 2,140 & 0,556 & $+0,600$ & 1,750 & 2,00 \\
\hline 4 (Faz. S. José) & 2,560 & 1,436 & $+0,574$ & 2,180 & 2,20 \\
\hline $46-M P$ & 2,580 & 1,370 & $+0,230$ & 1,250 & 2,40 \\
\hline $0 . M P$ & 3,030 & 1,000 & $+0,147$ & 1,200 & 3,00 \\
\hline 166 - PV & 2,570 & 0,960 & $+0,280$ & 1,280 & 2,50 \\
\hline 80 - PV & 1,900 & 1,572 & $+0,560$ & 1,540 & 1.45 \\
\hline 92 & 3,500 & 1,500 & $+0,360$ & 1,615 & 2,90 \\
\hline CV -7 * & 3,35 & 1,310 & $+0,410$ & 1,870 & 3,20 \\
\hline $1^{* *}$ & 2.62 & 1,540 & $+0,380$ & 1,217 & 2,25 \\
\hline $3 *$ & 3,23 & 1,955 & $+0,380$ & 1,160 & 2,80 \\
\hline $5^{* \star}$ & 2,63 & 1,750 & $+0,460$ & 1,260 & 2,20 \\
\hline $37^{*}$ & 3,02 & 1,310 & $+0,480$ & 0,695 & 2,80 \\
\hline $38^{* *}$ & 2,13 & 1,470 & $+0,515$ & 1,330 & 1,85 \\
\hline
\end{tabular}


Tabela de dados granulométricos e dos parâmetros estatísticos obtidos do Arenito Caiuá na região de Presidente Wenceslau (modificada de Landim \& Soares, 1976)

\begin{tabular}{|c|c|c|c|c|c|c|c|c|c|c|c|c|c|}
\hline \multirow{2}{*}{ Amostra } & \multicolumn{9}{|c|}{ Granulometria da fraçăo areia $(\varnothing)$} & \multicolumn{4}{|c|}{ Parâmetros Estatisticos } \\
\hline & 0 & 0,5 & 1 & 1,5 & 2 & 2,5 & 3 & 3,5 & 4 & $M_{z} \theta$ & $\delta_{1}$ & $S_{k}$ & $\mathrm{~K}_{\mathrm{g}}$ \\
\hline$M P-\uparrow^{*}$ & - & - & 0,2 & 0,5 & 8,45 & 27,3 & 33,4 & 13,8 & 3,2 & 2,6 & 0,5 & -0 & $\uparrow$ \\
\hline$M P-2^{*}$ & - & - & 0,1 & 2,2 & 9,52 & 15,9 & 20,3 & 14,6 & 7,2 & 2,7 & 0,7 & -0 & 0,9 \\
\hline SA 2 & 0 & 0,8 & 5,4 & 6,1 & 4,32 & 2,95 & 8,82 & 15,1 & 6,3 & 2,5 & 1,1 & $-0,4$ & 0,7 \\
\hline SA 1 & 0,1 & 0,7 & 3,3 & 3 & 2,46 & 3,29 & 9,69 & 17,6 & 9,6 & 2,8 & 1 & $-0,5$ & 1,3 \\
\hline C. 13 & - & - & 14 & 22 & 38,2 & 9,52 & 3,53 & 3,07 & 1,6 & 1,6 & 0,6 & 0,08 & 1,3 \\
\hline$T-14-10$ & . & . & - & 0,2 & 8,18 & 31,7 & 28,5 & 7,44 & 1,9 & 2,5 & 0,5 & 0,07 & 1 \\
\hline$T-14-09$ & - & - & - & 0,1 & 8,99 & 51 & 27,9 & 1,9 & 0,3 & 2,4 & 0,4 & 0,09 & 1 \\
\hline$T-14-08$ & . & - & 0 & 12 & 11,5 & 7,12 & 16,5 & 11,7 & 5,4 & 2,4 & 0,9 & $-0,2$ & 0,8 \\
\hline$T-14-07$ & - & - & 0,3 & 12 & 11,7 & 7,21 & 16,2 & 13 & 6,2 & 2,4 & 0,9 & $-0,2$ & 0,8 \\
\hline$T-14-06$ & & . & 0 & 8.3 & 12.6 & 8.16 & 20.7 & 19 & 4.9 & 2.5 & 0.4 & -0.2 & 0.8 \\
\hline
\end{tabular}


Tabela dos parâmetros estatísticos granulométricos e de arredondamento obtidos de análises granulométricas, de um poço em Marabá Paulista (segundo Arid et al., 1981)

\begin{tabular}{|c|c|c|c|c|c|c|}
\hline Amostra & Profundidade (m) & $M_{z}(\theta)$ & $\delta_{1}$ & $s_{k}$ & $k_{g}$ & Arredondamento \\
\hline 01 & 19,00 & 2,72 & 0,66 & $-0,58$ & 0,97 & 0,47 \\
\hline 02 & $26-32$ & 2,65 & 0,70 & $-0,21$ & 1,00 & 0,52 \\
\hline 03 & $32-35$ & 2,74 & 0,60 & $-0,01$ & 0,97 & 0,54 \\
\hline 04 & $35-38$ & 2,04 & 0,51 & $-0,21$ & 1,01 & 0,50 \\
\hline 05 & $38-40$ & 2,41 & 0,48 & 0,23 & 1,28 & 0,51 \\
\hline 06 & $40-42$ & 2,18 & 0,50 & $-0,01$ & 1,11 & 0,46 \\
\hline 07 & $42-46$ & 2,29 & 0,49 & 0,01 & 1,23 & 0,48 \\
\hline 08 & 47,00 & 2,35 & 1,10 & $-0,23$ & 0,62 & 0,52 \\
\hline 09 & 47,60 & 2,23 & 1,02 & $-0,12$ & 0,64 & 0,54 \\
\hline 10 & 47,80 & 1,93 & 0,73 & 0,28 & 0,95 & 0.54 \\
\hline 11 & 48,00 & 1,90 & 0,93 & 0,21 & 0,78 & 0,54 \\
\hline 12 & 49,00 & 1,85 & 0,57 & 0,10 & 1,02 & 0,54 \\
\hline 13 & 50,00 & 1,47 & 0,54 & 0,20 & 1,00 & 0,56 \\
\hline 14 & $51-52$ & 1,52 & 0,65 & 0,18 & 1,01 & 0,55 \\
\hline 15 & 52.53 & 1,75 & 0,66 & 0,07 & 0,92 & 0,54 \\
\hline 16 & $53-54$ & 1,56 & 0,63 & 0,57 & 0,80 & 0,54 \\
\hline 17 & $54-54,5$ & 1,36 & 0,64 & 0,53 & 1,06 & 0,58 \\
\hline 18 & 55,00 & 1,69 & 0,75 & 0,69 & 0,94 & 0,55 \\
\hline 19 & $55,50-56,50$ & 1,44 & 0,65 & 0,25 & 1,05 & 0,61 \\
\hline 20 & $57-58$ & 1,86 & 0,87 & 0.20 & 0,98 & 0,61 \\
\hline 21 & $58-60$ & 1,75 & 0,65 & $-0,01$ & 0,91 & 0,58 \\
\hline 22 & $60-61$ & 1,60 & 0,65 & 0,00 & 0,97 & 0,60 \\
\hline 23 & 61,50 & 1,76 & 0,63 & $-0,08$ & 1,02 & 0,58 \\
\hline 24 & 63,00 & 1,66 & 0,77 & $-0,34$ & 1,50 & 0,62 \\
\hline 25 & 64,00 & 2,49 & 0,79 & $-0,25$ & 1,00 & 0,60 \\
\hline 26 & $65-67$ & 1,72 & 0,65 & $-0,49$ & 1,58 & 0,65 \\
\hline 27 & 67,00 & 2,04 & 0,99 & $-0,16$ & 0,74 & 0,64 \\
\hline 28 & 70,00 & 2,35 & 0,78 & $-0,21$ & 1,00 & 0,56 \\
\hline 29 & $70-75$ & 1,27 & 0,66 & 0,51 & 0,88 & 0,68 \\
\hline 30 & $75-80$ & 1,39 & 0,76 & 0,23 & 0,87 & 0,70 \\
\hline 31 & 80,00 & 1,07 & 0,27 & 0,30 & 1,18 & 0,64 \\
\hline 32 & 81,00 & 1,04 & 0,26 & 0,26 & 1,38 & 0,66 \\
\hline 33 & 85,00 & 1,31 & 0,54 & 0,19 & 1,60 & 0,68 \\
\hline 34 & $90-98,50$ & 1,22 & 0,51 & 0,61 & 0,25 & 0,70 \\
\hline 35 & $98,50-100,00$ & 1,08 & 0,43 & 0,34 & 1,98 & 0,64 \\
\hline
\end{tabular}


ANEXO 5

Minerais pesados 
Tabela da composição percentual de ocorrência de minerais pesados da topossequêencia do sítio Três Leões

\begin{tabular}{|c|c|c|c|c|}
\hline Amostra & Estaurolita & Rutilo & Turmalina & Zircåo \\
\hline TRI- 1 & 47 & - & 30 & 23 \\
\hline TRI- 2 & 36 & 09 & 31 & 24 \\
\hline TRI- 3 & 41 & 01 & 34 & 24 \\
\hline TRI- 4 & 40 & 02 & 22 & 36 \\
\hline TRI- 5 & 42 & 01 & 32 & 25 \\
\hline Média & 42 & 03 & 29 & 26 \\
\hline TRIII- 1 & 34 & 03 & 31 & 32 \\
\hline TRIH- 2 & 24 & 05 & 35 & 36 \\
\hline TRIII- 3 & 25 & 08 & 36 & 31 \\
\hline TRIII- 5 & 23 & 03 & 38 & 36 \\
\hline Média & 26 & 05 & 35 & 34 \\
\hline TRV-1 & 11 & 05 & 32 & 52 \\
\hline TRV- 2 & 21 & 06 & 24 & 49 \\
\hline TRV-3 & 11 & 16 & 30 & 43 \\
\hline TRV - 4 & 13 & 06 & 40 & 41 \\
\hline TRV- 5 & 19 & 07 & 29 & 45 \\
\hline Média & 15 & 08 & 31 & 46 \\
\hline
\end{tabular}




\begin{tabular}{|c|c|c|c|c|}
\hline Amostra & Estaurolita & Rutilo & Turmalina & Zircăo \\
\hline TRI- 0 & 43 & 01 & 33 & 23 \\
\hline TR!- 1 & 38 & 02 & 29 & 31 \\
\hline TRI- 2 & 42 & 04 & 30 & 24 \\
\hline TRI- 3 & 36 & 01 & 32 & 31 \\
\hline TRI- 5 & 46 & - & 35 & 19 \\
\hline Média & 41 & 01 & 32 & 26 \\
\hline TRII- 1 & 42 & 01 & 32 & 25 \\
\hline TRII- 2 & 38 & 02 & 27 & 33 \\
\hline TRII- 3 & 49 & 03 & 28 & 20 \\
\hline TRII- 5 & 32 & 01 & 18 & 49 \\
\hline Média & 40 & 02 & 26 & 32 \\
\hline TRV- 1 & 48 & 04 & 17 & 31 \\
\hline TRV- 2 & 36 & 02 & 29 & 33 \\
\hline TRV - 3 & 37 & 02 & 28 & 33 \\
\hline Média & 40 & 03 & 25 & 32 \\
\hline
\end{tabular}


Tabela da composição percentual de ocorrencia de minerais pesados da topossequiência de Umuarama

\begin{tabular}{|c|c|c|c|c|}
\hline Amostra & Estaurolita & Rutilo & Turmalina & Zircăo \\
\hline TRI- 1 & 31 & 02 & 37 & 11 \\
\hline TRI- 2 & 44 & 03 & 46 & 27 \\
\hline TRI- 3 & 39 & 01 & 43 & 16 \\
\hline Média & 38 & 02 & 42 & 18 \\
\hline TRII- 1 & 48 & 01 & 47 & 11 \\
\hline TRII- 2 & 41 & -- & 39 & 09 \\
\hline TRII- 3 & 39 & 02 & 45 & 12 \\
\hline TRII- 4 & 44 & 01 & 45 & 16 \\
\hline Média & 43 & 01 & 44 & 12 \\
\hline TRIII- 1 & 57 & - & 43 & 16 \\
\hline TRIII- 2 & 45 & - & 39 & 21 \\
\hline TRIII- 3 & 48 & - & 44 & 17 \\
\hline Média & 50 & - & 42 & 18 \\
\hline
\end{tabular}




\begin{tabular}{|c|c|c|c|c|}
\hline Amostra & Estaurolita & Rutilo & Turmalina & Zircáo \\
\hline TRI- 1 & 19 & 05 & 33 & 43 \\
\hline TRI- 2 & 09 & 15 & 39 & 37 \\
\hline TRI- 3 & 08 & 13 & 27 & 52 \\
\hline TRI- 4 & 08 & 10 & 25 & 54 \\
\hline Média & 14 & 10 & 32 & 47 \\
\hline TRII- 1 & 12 & 07 & 27 & 54 \\
\hline TRII- 2 & 10 & 09 & 27 & 54 \\
\hline TRII- 3 & 17 & 05 & 26 & 52 \\
\hline TRII- 4 & 09 & 09 & 32 & 50 \\
\hline TRII- 5 & 03 & 05 & 21 & 68 \\
\hline Média & 10 & 07 & 27 & 56 \\
\hline TRIII- 1 & 10 & 07 & 42 & 38 \\
\hline TRIll- 2 & 14 & 05 & 31 & 46 \\
\hline TRIII- 3 & 13 & 10 & 38 & 35 \\
\hline Média & 13 & 07 & 38 & 42 \\
\hline
\end{tabular}

